NATIONALWATER-QUALITY ASSESSMENT PROGRAM, NATIONALSYNTHESIS ON VOLATILE ORGANIC COMPOUNDS

\title{
Occurrence and Distribution of Methyl tert-Butyl Ether and Other Volatile Organic Compounds in Drinking Water in the Northeast and Mid-Atlantic Regions of the United States, 1993-98
}

Water-Resources Investigations Report 00-4228

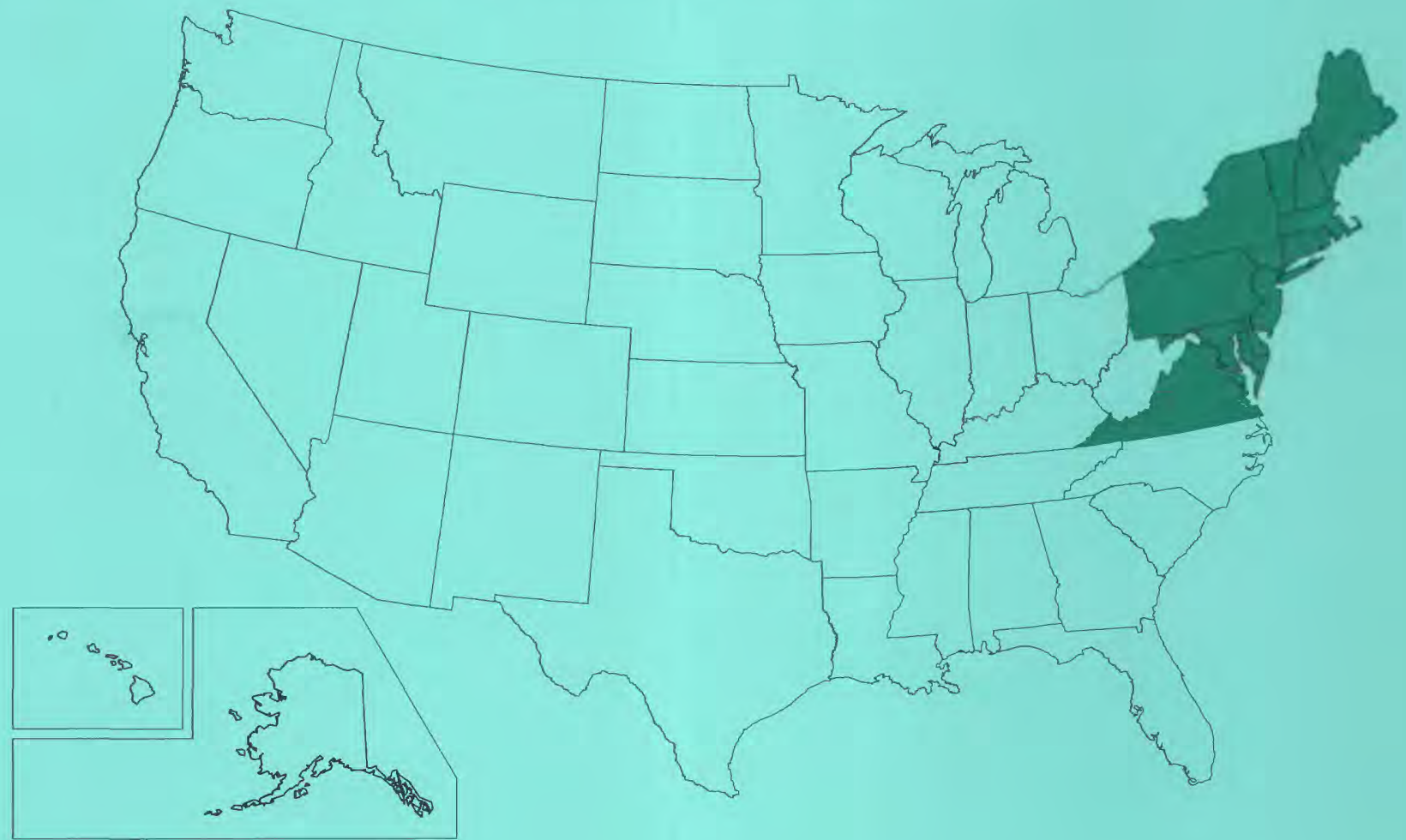

Prepared in cooperation with the U.S. Environmental Protection Agency, Office of Ground Water and Drinking Water

U.S. Department of the Interior

U.S. Geological Survey 


\section{Occurrence and Distribution of Methyl tert-Butyl Ether and Other Volatile Organic Compounds in Drinking Water in the Northeast and Mid-Atlantic Regions of the United States, 1993-98}

By Stephen J. Grady and George D. Casey

Water-Resources Investigations Report 00-4228

Prepared in cooperation with the U.S. Environmental Protection Agency, Office of Ground Water \& Drinking Water 
U.S. Department of the Interior

GALE A. NORTON, Secretary

U.S. Geological Survey

CHARLES G. GROAT, Director

The use of firm, trade, and brand names in this report is for identification purposes only and does not constitute endorsement by the U.S. Government.

East Hartford, Connecticut: 2001

For additional information write to:

District Chief

U.S. Geological Survey

101 Pitkin Street

East Hartford, CT 06108

Copies of this report can be purchased from:

U.S. Geological Survey

Branch of Information Services

Building 810

Box 25286, Federal Center

Denver, C0 80225-0286 


\section{FOREWORD}

The U.S. Geological Survey (USGS) is committed to serve the Nation with accurate and timely scientific information that helps enhance and protect the overall quality of life, and facilitates effective management of water, biological, energy, and mineral resources. Information on the quality of the Nation's water resources is of critical interest to the USGS because it is so integrally linked to the longterm availability of water that is clean and safe for drinking and recreation and that is suitable for industry, irrigation, and habitat for fish and wildlife. Escalating population growth and increasing demands for the multiple water uses make water availability, now measured in terms of quantity and quality, even more critical to the long-term sustainability of our communities and ecosystems.

The USGS implemented the National WaterQuality Assessment (NAWQA) Program to support national, regional, and local information needs and decisions related to water-quality management and policy. Shaped by and coordinated with ongoing efforts of other Federal, State, and local agencies, the NAWQA Program is designed to answer: What is the condition of our Nation's streams and ground water? How are the conditions changing over time? How do natural features and human activities affect the quality of streams and ground water, and where are those effects most pronounced? By combining information on water chemistry, physical characteristics, stream habitat, and aquatic life, the NAWQA Program aims to provide science-based insights for current and emerging water issues. NAWQA results can contribute to informed decisions that result in practical and effective water-resource management and strategies that protect and restore water quality.

Since 1991, the NAWQA Program has implemented interdisciplinary assessments in more than 50 of the Nation's most important river basins and aquifers, referred to as Study Units. Collectively, these Study Units account for more than 60 percent of the overall water use and population served by public water supply, and are representative of the Nation's major hydrologic landscapes, priority ecological resources, and agricultural, urban, and natural sources of contamination.
Each assessment is guided by a nationally consistent study design and methods of sampling and analysis. The assessments thereby build local knowledge about water-quality issues and trends in a particular stream or aquifer while providing an understanding of how and why water quality varies regionally and nationally. The consistent, multi-scale approach helps to determine if certain types of waterquality issues are isolated or pervasive, and allows direct comparisons of how human activities and natural processes affect water quality and ecological health in the Nation's diverse geographic and environmental settings. Comprehensive assessments on pesticides, nutrients, volatile organic compounds, trace metals, and aquatic ecology are developed at the national scale through comparative analysis of th ${ }^{\circ}$ Study-Unit findings.

The USGS places high value on the communication and dissemination of credible, timely, and relevant science so that the most recent and available knowledge about water resources can be applied in management and policy decisions. We hope this NAWQA publication will provide you the needed insights and information to meet your needs, and thereby foster increased awareness and involvem the protection and restoration of our Nation's waters.

The NAWQA Program recognizes that a national assessment by a single program cannot address all water-resource issues of interest. External coordination at all levels is critical for a fully integrated understanding of watersheds and for costeffective management, regulation, and conservat:on of our Nation's water resources. The Program, therefore, depends extensively on the advice, cooperation, and information from other Federal, State, interstate, Tribal, and local agencies, non-government organizations, industry, academia, and other stakeholder groups. The assistance and suggestions of all are greatly appreciated.
Robert M. Hirsch

Associate Director for Water 



\section{CONTENTS}

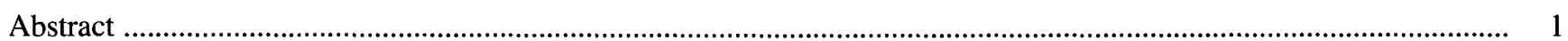

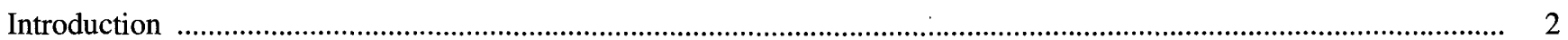

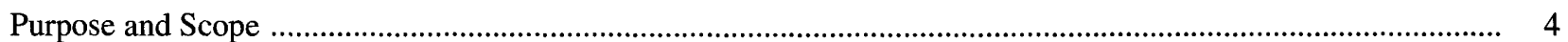

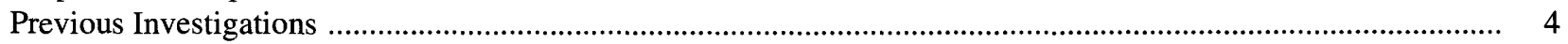

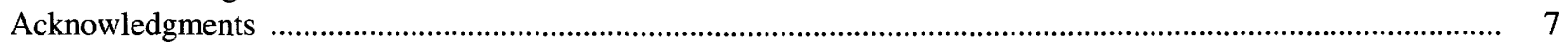

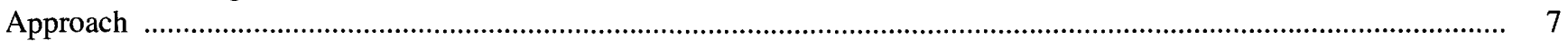

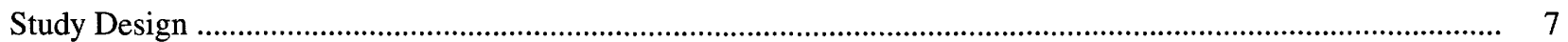

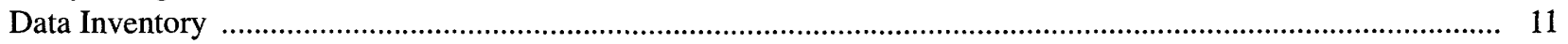

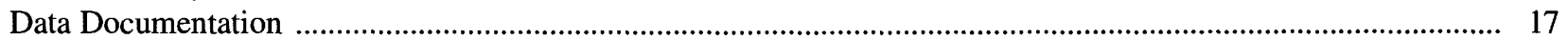

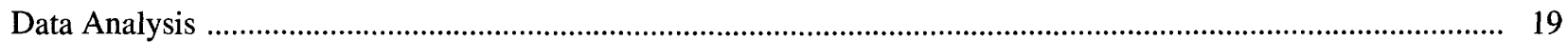

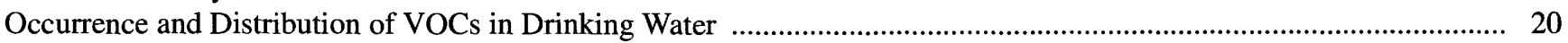

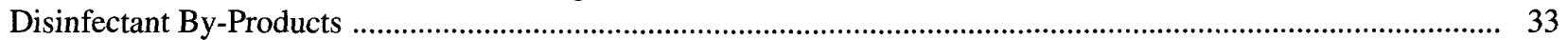

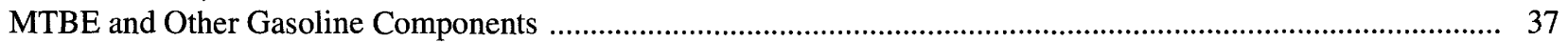

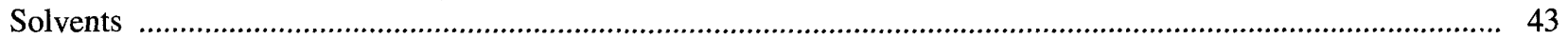

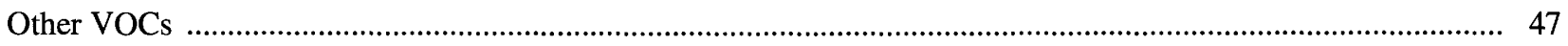

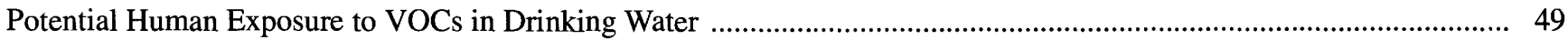

Actual Population Served by Randomly Selected CWSs ............................................................................ 49

Estimated Population Served by All CWSs ......................................................................................... 53

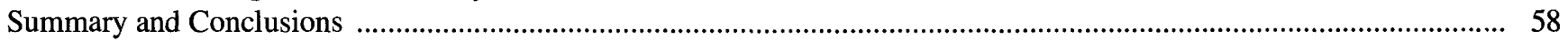

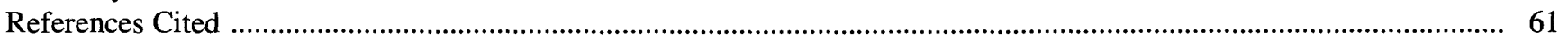

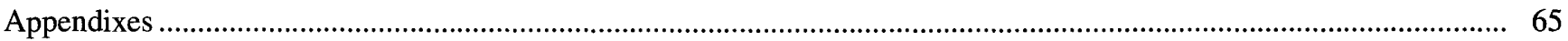

Appendix 1. Volatile organic compounds included in analyses of drinking water for randomly selected community water systems in the study area, 1993-98

Appendix 2. Availability of data on volatile organic compounds in analyses of drinking water for randomly selected community water systems in the study area compared by State, 1993-98.....

Appendix 3. Frequency of reporting and frequency of detection of volatile organic compounds included in analyses of drinking water for randomly selected community water systems in the study area compared by reporting levels, 1993-98

Appendix 4. Co-occurrence of volatile organic compounds in drinking water for randomly selected community water systems in the study area, 1993-98 
1-2. Maps showing:

1. The 12-State study area, Northeast and Mid-Atlantic regions

2. Drinking-water sources of water for randomly selected community water systems in the study area showing (A) ground-water sources and (B) surface-water sources

3-4. Graphs showing:

3. Cumulative distribution of concentrations of volatile organic compounds detected in drinking-water samples from randomly selected community water systems in the study area, 1993-98

4. Frequency of detection of volatile organic compounds at concentrations equal to or exceeding 1.0 microgram per liter in drinking water from randomly selected community water systems in the study area for (A) 20 volatile organic compounds with detection frequencies greater than 1 percent and (B) 34 volatile organic compounds with detection frequencies less than 1 percent

5-6. Maps showing:

5. Drinking-water sources for randomly selected community water systems in the study area, showing systems with analytical data and systems with reported detectable concentrations of any volatile organic compound, in relation to urban land use

6. Drinking-water sources for randomly selected community water systems in the study area, showing systems with analytical data and systems with reported detectable concentrations of any non-trihalomethane volatile organic compound, in relation to urban land use

7-9. Graphs showing:

7. Frequency of co-occurrence of volatile organic compounds in drinking-water samples from randc mly selected community water systems in the study area

8. Distribution of median total trihalomethane concentrations in drinking water from randomly selected community water systems in study area compared by source of water

9. Frequency of detection of methyl tert-butyl ether at or above 1.0 microgram per liter in drinking water from randomly selected community water systems in 10 Northeast and Mid-Atlantic States, 1993-98 ......

10. Map showing drinking-water sources for randomly selected community water systems in the study area, showing systems with analytical data and those systems with reported detectable concentrations for methyl tert-butyl, in relation to areas where oxygenated and (or) reformulated gasoline is currently or was formerly used

11-12. Graphs showing:

11. Comparison of cumulative distributions of median methyl tert-butyl ether concentrations in drinking water for randomly selected community water systems to selected public water systems in the study area

12. Comparison of methyl tert-butyl ether concentrations to the sum of the concentrations of benzene, ethylbenzene, toluene, and xylenes in drinking-water samples from randomly selected communit: water systems in the study area

13. Map showing drinking-water sources for randomly selected community water systems in the study area, showing systems with analytical data and systems with reported detectable concentrations of any solvents, in relation to urban land use

14. Graph showing frequency of detection of solvents at or above 1.0 microgram per liter in drinking wate* from randomly selected community water systems in the study area, 1993-98

15. Map showing drinking-water sources for randomly selected community water systems in the study are?, showing systems with analytical data and systems with reported detectable concentrations of any fumigants, in relation to urban land use

\section{TABLES}

1. Distribution of community water systems in the study area on December 1, 1997 by State, principal source of water, and population served

2. Targeted distribution of community water systems inventoried by State, principal source of water, and population served

3. Actual distribution of randomly selected community water systems inventoried by State, source of water, and population served

. Population served by community water systems in the study area

5. Availability of data on volatile organic compounds in drinking water for the study area, 1978-98

\section{Contents}


6. Period of record for data compiled on volatile organic compounds and methyl tert-butyl ether in drinking water from randomly selected community water systems in the study area .......

7. Volatile organic compounds detected in drinking water from randomly selected community water systems in the study area, 1993-98

8. Volatile organic compounds that equaled or exceeded regulated or recommended concentrations in drinking water from randomly selected community water systems in the study area, 1993-98

9. Frequency of detection of volatile organic compounds at any reporting level in drinking water from randomly selected community water systems in the study area, 1993-98

10. Volatile organic compounds undetected in drinking water from randomly selected community water systems in the study area, 1993-98

11. Randomly selected community water systems in the study area reporting concentrations at or above 1.0 microgram per liter of 54 selected volatile organic compounds in drinking water by State, source of water, and population served, 1993-98

12. Comparison of the frequency of detection of volatile organic compounds at concentrations at or above 1.0 microgram per liter in drinking water from randomly selected community systems in the study area by source of water and size, 1993-98

13. Comparison between average population density and the frequency of detection of volatile organic compounds at concentrations at or above 1.0 microgram per liter in drinking water in the study area, 1993-98

14. Relations between the occurrence of volatile organic compounds at or above 1.0 microgram per liter and at concentrations that equal or exceed a drinking-water regulation or recommendation in drinking water from randomly selected community water systems in the study area and source of water, size of system, and land use at sources

15. Frequency of detection and median concentrations of trihalomethanes in drinking water from randomly selected community water systems in the study area compared by source of water

16. Co-occurrence of trihalomethane compounds in drinking water from randomly selected community water systems in the study area

17. Co-occurrence of gasoline components in drinking water from randomly selected community water systems in the study area

18. Co-occurrence of selected solvents in drinking water from randomly selected community water systems in the study area

19. Population served by randomly selected community water systems in the study area with detections of 64 volatile organic compounds in drinking water, 1993-98

20. Population served by randomly selected community water systems reporting detectable concentrations of volatile organic compounds in drinking water in the study area, 1993-98

21. Estimated number of community water systems and population in the study area that may have had detectable concentrations of volatile organic compounds in drinking water during 1993-98 based on extrapolation from randomly selected community water systems

22. Estimated number of community water systems that may have had detectable concentrations of volatile organic compounds in drinking water during 1993-98 based on extrapolation of frequency of detection for each State

23. Estimated number of people served by community water systems that may have had detectable concentrations of volatile organic compounds in drinking water during 1993-98 based on extrapolation of population served by random systems with detections for each State 
CONVERSION FACTORS AND ABBREVIATIONS

\begin{tabular}{rcl}
\hline Multiply & \multicolumn{1}{c}{ By } & To obtain \\
\hline inch (in.) & Length & \\
inch (in.) & 2.54 & centimeter \\
foot (ft) & 0.3048 & millimeter \\
mile (mi) & 1.609 & meter \\
& Area & kilometer \\
\hline square mile (mi $\left.\mathrm{mi}^{2}\right)$ & 259.0 & hectare \\
square mile $\left(\mathrm{mi}^{2}\right)$ & 2.590 & square kilometer \\
\hline
\end{tabular}

Temperature in degrees Celsius $\left({ }^{\circ} \mathrm{C}\right)$ may be converted to degrees Fahrenheit $\left({ }^{\circ} \mathrm{F}\right)$ as follows:

$$
{ }^{\circ} \mathrm{F}=\left(1.8 \times{ }^{\circ} \mathrm{C}\right)+32
$$

Temperature in degrees Fahrenheit $\left({ }^{\circ} \mathrm{F}\right)$ may be converted to degrees Celsius $\left({ }^{\circ} \mathrm{C}\right)$ as follows:

$$
{ }^{\circ} \mathrm{C}=\left({ }^{\circ} \mathrm{F}-32\right) / 1.8
$$

Concentrations of chemical constituents in water are given in micrograms per liter $(\mu \mathrm{g} / \mathrm{L})$. 


\title{
Occurrence and Distribution of Methyl tert-Butyl Ether and Other Volatile Organic Compounds in Drinking Water in the Northeast and Mid-Atlantic Regions of the United States, 1993-98
}

\author{
By Stephen J. Grady and George D. Casey
}

\section{ABSTRACT}

Data on volatile organic compounds (VOCs) in drinking water supplied by 2,110 randomly selected community water systems (CWSs) in 12 Northeast and Mid-Atlantic States indicate $64 \mathrm{VOC}$ analytes were detected at least once during 1993-98. Selection of the 2,110 CWSs inventoried for this study targeted 20 percent of the 10,479 active CWSs in the region and represented a random subset of the total distribution by State, source of water, and size of system. The data include 21,635 analyses of drinking water collected for compliance monitoring under the Safe Drinking Water Act; the data mostly represent finished drinking water collected at the pointof-entry to, or at more distal locations within, each CWS's distribution system following any watertreatment processes. VOC detections were more common in drinking water supplied by large systems (serving more than 3,300 people) that tap surface-water sources or both surface- and groundwater sources than in small systems supplied exclusively by ground-water sources.

Trihalomethane (THM) compounds, which are potentially formed during the process of disinfecting drinking water with chlorine, were detected in 45 percent of the randomly selected CWSs. Chloroform was the most frequently detected THM, reported in 39 percent of the CWSs. The gasoline additive methyl tert-butyl ether (MTBE) was the most frequently detected VOC in drinking water after the THMs. MTBE was detected in 8.9 percent of the 1,194 randomly selected CWSs that analyzed samples for MTBE at any reporting level, and it was detected in 7.8 percent of the 1,074 CWSs that provided MTBE data at the $1.0-\mu \mathrm{g} / \mathrm{L}$ (microgram per liter) reporting level. As with other VOCs repoted in drinking water, most MTBE concentrations were less than $5.0 \mu \mathrm{g} / \mathrm{L}$, and less than 1 percent of CWSs reported MTBE concentrations at or above the $20.0-\mu \mathrm{g} / \mathrm{L}$ lower limit recommended ty the U.S. Environmental Protection Agency's Drinking-Water Advisory.

The frequency of MTBE detections in drinking water is significantly related to righMTBE-use patterns. Detections are five times more likely in areas where MTBE is or has been used in gasoline at greater than 5 percent by volume as part of the oxygenated or reformulated (OXY/RFG) fuels program. Detection freauencies of the individual gasoline compounds (berzene, toluene, ethylbenzene, and xylenes (BTEY')) were mostly less than 3 percent of the randomly selected CWSs, but collectively, BTEX compounc's were detected in 8.4 percent of CWSs. BTEX concentrations also were low and just three drinkingwater samples contained BTEX at concer rations exceeding $20 \mu \mathrm{g} / \mathrm{L}$. Co-occurrence of MTBE and BTEX was rare, and only 0.8 percent of CWSs reported simultaneous detections of MTBE and BTEX compounds. Low concentrations and cooccurrence of MTBE and BTEX indicate most gasoline contaminants in drinking water probably represent nonpoint sources.

Solvents were frequently detected in drinking water in the 12-State area. One or more of 27 individual solvent VOCs were detected at any reporting level in 3,080 drinking-water samples 
from 304 randomly selected CWSs (14 percent) and in $206 \mathrm{CWSs}$ (9.8 percent) at concentrations at or above $1.0 \mu \mathrm{g} / \mathrm{L}$. High co-occurrence among solvents probably reflects common sources and the presence of transformation by-products. Other VOCs were relatively rarely detected in drinking water in the 12-State area. Six percent (127) of the 2,110 randomly selected CWSs reported concentrations of 16 VOCs at or above drinking-water criteria. The $127 \mathrm{CWS}$ collectively serve 2.6 million people.

The occurrence of VOCs in drinking water was significantly associated $(\mathrm{p}<0.0001)$ with highpopulation-density urban areas. New Jersey, Massachusetts, and Rhode Island, States with substantial urbanization and high population density, had the highest frequency of VOC detections among the 12 States. More than two-thirds of the randomly selected CWSs in New Jersey reported detecting VOC concentrations in drinking water at or above $1.0 \mu \mathrm{g} / \mathrm{L}$.

Ninety-two percent of the 9.6 million people served by the 2,110 randomly selected CWSs inventoried for this study, or 8.8 million people, get their drinking water from a CWSs that has reported at least one detection of a VOC during 1993-98. Projections of the total number of systems that may have experienced detections of VOCs during this time period indicate 4,700 CWSs may have been similarly affected. Estimates of the number of people potentially exposed to VOCs in drinking water in the 12 -State area during this time period range from 52 to 54 million. Thirty-four percent of the population served by randomly selected CWSs with data for MTBE may have been exposed to the gasoline additive in their drinking water. Extrapolation of the frequency of detection and the percentage of population potentially exposed to MTBE from the random sample to all CWSs for the 12-State area provides estimates of about $900 \mathrm{CWSs}$ and 17 to 20 million people.

\section{INTRODUCTION}

Methyl tert-butyl ether (MTBE) is a chemical compound that is added to gasoline in some areas of the
United States to control air pollution and to enhance the octane level. With the phaseout of tetraethyl lead from gasoline in the 1970s, MTBE was blended in some conventional gasoline at low concentrations (about 1 to 7 percent by volume) to enhance octane ratings and improve combustion. The Clean Air Act Amendments (CAAA) of 1990 mandated use of oxygenates (oxygencontaining compounds) in areas where atmospheric concentrations of ozone in summer and carbon monoxide in winter exceed established air-quality standards. Although the CAAA did not stipulate which oxygenate must be added to gasoline, MTBE is the primary oxygenate used, especially in the Northeast and Mid-Atlantic States. When MTBE is used in oxygenated gasoline (OXY), the concentration of MTBE is approximately 15 percent by volume.

Several urban areas presently or formerly included in the wintertime OXY fuel program, which began in November 1992, are in the Northeast or MidAtlantic States. In 1995, use of MTBE expandad in parts of the Nation, including much of the Northeast and Mid-Atlantic regions, with the introduction of reformulated gasoline (RFG). RFG has about 11 percent MTBE by volume and is now or was formerly used year-round in all or some parts of 11 of the 12 States in this study. Annual domestic production of MTBE has increased substantially, from 1.65 million barrels in 1980 to 75 million barrels in 1998 (U.S. Department of Energy, 1999), and nearly douk ${ }^{1}$ ed over the 6-year period (1993-98) examined for this study. MTBE currently is used as an oxygenate in at out onethird of all gasoline sold in the United States.

MTBE is a volatile organic compound (VOC), a group of natural and manmade chemicals that are typically characterized by high vapor pressures, high solubilities in water, and low octanol-water partition coefficients. A variety of chemicals including some hydrocarbons, halocarbons, aldehydes, ketones, alcohols, acids, ethers, and methyl-sulfur compounds can be classified as VOCs. These chemicals are used and (or) produced in the manufacture of paints, achesives, petroleum products, pharmaceuticals, and refrigerants. VOCs are the principal or active components of products commonly used in urban settings, such as fuels, solvents, hydraulic fluids, paint, and dry cleaning agents and the active and (or) inert components of products used in agricultural setting, such as pasticides (particularly fumigants). 
Contamination of drinking-water supplies by VOCs is a human health concern because many compounds are toxic and are known or suspected human carcinogens (U.S. Environmental Protection Agency, 1996). The U.S. Environmental Protection Agency (USEPA) has established maximum contaminant levels (MCLs) for 21 VOCs (plus two fumigants, ethylene dibromide (EDB) and dibromochloropropane (DBCP), classified by the USEPA as "synthetic organic compounds;" see appendix 1) that are currently regulated in public drinking water under the Safe Drinking Water Act (SDWA). Most public drinking water also is monitored for 21 unregulated VOCs as per SDWA requirements. Monitoring for an additional 14 VOCs can be required of public water systems (PWSs) at the discretion of individual States.

MTBE may be released into the environment from point sources, such as leaks or spills, that may take place during the refinement, distribution, storage, and use of gasoline; some of these leaks or spills have resulted in the loss of domestic and public water supplies (Office of Science and Technology Policy, 1997; Hitzig and others, 1998). It has been estimated that 9 million barrels of gasoline, or roughly the volume of one supertanker, are released into the environment each year in the United States (Alliance for Proper Gasoline Handling, 1999). Furthermore, the release of MTBE to the atmosphere and the hydrosphere from nonpoint sources, such as automobile emissions and evaporative losses, may result in low concentrations of MTBE in water in urban areas (Pankow and others, 1997; Baehr and others, 1999). The physical and chemical properties of MTBE-its high solubility, low sorption, and limited anaerobic biodegradation-together with its large-scale production and use have made MTBE one of the most frequently detected contaminants in ground water in recent National assessments (Squillace and others, 1996; Zogorski and others, 1998; Moran and others, 1999).

The presence of MTBE in drinking water is a potential human health concern, and at low concentrations, its presence may adversely affect the taste and odor of drinking water, causing it to be unpotable (Young and others, 1996; Malcome Pirnie, Inc., 1998; California Department of Health Services, 1999). USEPA has issued a drinking-water advisory that recommends a range of 20 to $40 \mu \mathrm{g} / \mathrm{L}$ as a limit to address taste and odor concerns (U.S. Environmental Protection Agency, 1997). The USEPA advisory concentration range for MTBE also is intende 1 to provide a safety margin for potential carcinogenic effects and to provide a large margin of safety for noncancerous effects (U.S. Environmental Protection Agency, 1997). The USEPA has tentatively classified MTBE as a Group C, or possible human carcinogen (U.S. Environmental Protection Agency, 1996).

Although analysis of drinking-water samples for MTBE is not presently required under the SDWA, some States and (or) public drinking-water suppliers have included MTBE in chemical analyses of drinkingwater samples in recent years. Despite this, the report of the Interagency Assessment of Oxygenated Fuels was unable to adequately describe the occurrence of MTBE in the Nation's drinking water from the limited data available in 1997 (Zogorski and others, 1997) and recommended that additional data on MTBE in drinking water be collected. The USEPA also has noted that "based on limited monitoring and occurrence data, a potential for exposure of......human populations to oxygenates exists" (U.S. Environmental Protection Agency, 1998a, p. 19), and that obtaining dat from public water suppliers would help determine the "prevalence and level of potential exposures." Monitoring for MTBE will be required for some but not all PWSs beginning in 2001 (U.S. Environmental Protection Agency, 1999a).

Questions and concerns have been raised about MTBE and VOCs in drinking water. Some of these include:

- The widespread use of the gasoline additive MTBE has contaminated public drinking water, but does the occurrence of MTBE in drinking water change substantially in space and time and does it ref ect different MTBE-use patterns?

- What other VOCs have been detected in drinking water? How frequently have regulated VOCs been detected at concentrations below MCLs? How frequently have unregulated VOCs been detected in drinking water at any concentration? How often does MTBE co-occur with other VOCs? Also, if MTBE and other VOCs occur widely in drinking water, can estimates be made of how many people may have been exposed to VOCs through consumption of affected drinking water? 
- Does the frequency of VOC detections differ among States? Are VOCs detected more frequently in drinking water obtained from ground-water sources than that obtained from surface-water sources? Does the type and frequency of VOCs detected differ substantially between source waters and finished waters? If so, can the occurrence of VOCs in drinking water be related to the size of public water systems and level of water treatment they provide?

In an effort to provide answers to these questions, the U.S. Geological Survey (USGS), in cooperation with the USEPA, conducted an assessment of the occurrence and distribution of MTBE and other VOCs in public drinking water in the Northeast and MidAtlantic regions of the United States during 1993-98. This report describes the effort to compile, evaluate, and analyze existing information on the quality of public drinking water collected by water suppliers and State or local health or environmental agencies.

\section{Purpose and Scope}

This report describes the occurrence and distribution of MTBE and other VOCs in public drinking water supplied by a representative sample of the CWSs in a 12-State area of the Northeast and Mid-Atlantic regions of the United States (fig. 1) referred to as the study area. CWSs are PWSs that provide water year round to at least 25 people or have a minimum of 15 residential service connections. This report provides information on the frequency of detection, concentration, and distribution of MTBE and other VOCs in drinking water, and evaluates the extent of possible human exposure within the study area to these compounds in drinking water. Information on the occurrence and distribution of MTBE in drinking water will be used (1) by the USEPA to make a determination whether to proceed with developing a national standard for MTBE in support of the new risk-based contaminant selection and regulation process under the SDWA Amendments of 1996 (Sakata and Osinski, 1999), and (2) by the USGS to better characterize the quality of the Nation's water resources in general (Gilliom and others, 1995) and specifically with respect to VOCs in ground water from major aquifers (Lapham and Tadayon, 1996).

The report summarizes information on the quality of drinking water from 2,110 randomly selected CWSs in the study area. Water-quality data, including more than 21,000 chemical analyses for VOCs in drinking-water samples collected from 1993 to 1998 in compliance with SDWA monitoring requirements, were compiled and analyzed for this study. The study area (fig. 1) includes the six New England States (Connecticut, Maine, Massachusetts, New Hampshire, Rhode Island, and Vermont), three other northeastern States (New Jersey, New York, and Pennsylvania), three Mid-Atlantic States (Delaware, Maryland, and Virginia), and Washington, D.C.

\section{Previous Investigations}

No previous studies specifically have focused on the occurrence and distribution of MTBE, or other VOCs in general, in public drinking water across the study area, but a few national studies of VOC $s$ in drinking water or ambient ground water included data for at least some of the 12 Northeast and Mid-Atlantic States. Also, a few recent studies have focused on MTBE or other VOCs in ground water, surface water, and (or) drinking water for specific States, parts of States, or groups of States in the region. These studies are identified and briefly summarized below.

A review of the occurrence and distribution of VOCs in drinking water by Westrick and othe"s (1984) reported that 23 VOCs were detected in finished drinking water supplied by nearly one-fourth (230) of 945 water systems throughout the United Sta ${ }^{+}$s sampled during 1981 and 1982. The "ground-water supply survey" included 34 VOC analytes but not MTBE. Overall, detection frequencies ranged from about 17 percent of samples from small, randomly selected PWSs, to 37 percent of samples from large systems selected for sampling because they had been identified as "problem systems." The most fr?quently detected VOCs were four trihalomethanes (THMs)-chloroform, bromodichloromethane, chlorodibromomethane, and bromoform-present in 45, 43,39 , and 22 percent of the systems sampled, respectively. Trihalomethanes, which are halogenate 1 organic compounds that may form during the process of disinfecting drinking water with chlorine, were detected more often from large systems (serving more than 10,000 people) than from small systems that were less likely to chlorinate their source water. After the trihalomethanes, four commonly used solvents-tetrachloroethylene, trichloroethylene, 1,1,1-trichloroethane, and 1,1-dichloroethane-were the next most frequently detected compounds, present in 4 to 7 percent of the systems sampled. Fifty-three prrcent of the samples with VOC detections contained more than one VOC. The relatively high detection frequencies, the age of the data, and limited analytical coverage point to the need for a current and comprehensive picture of VOCs in public drinking water. 


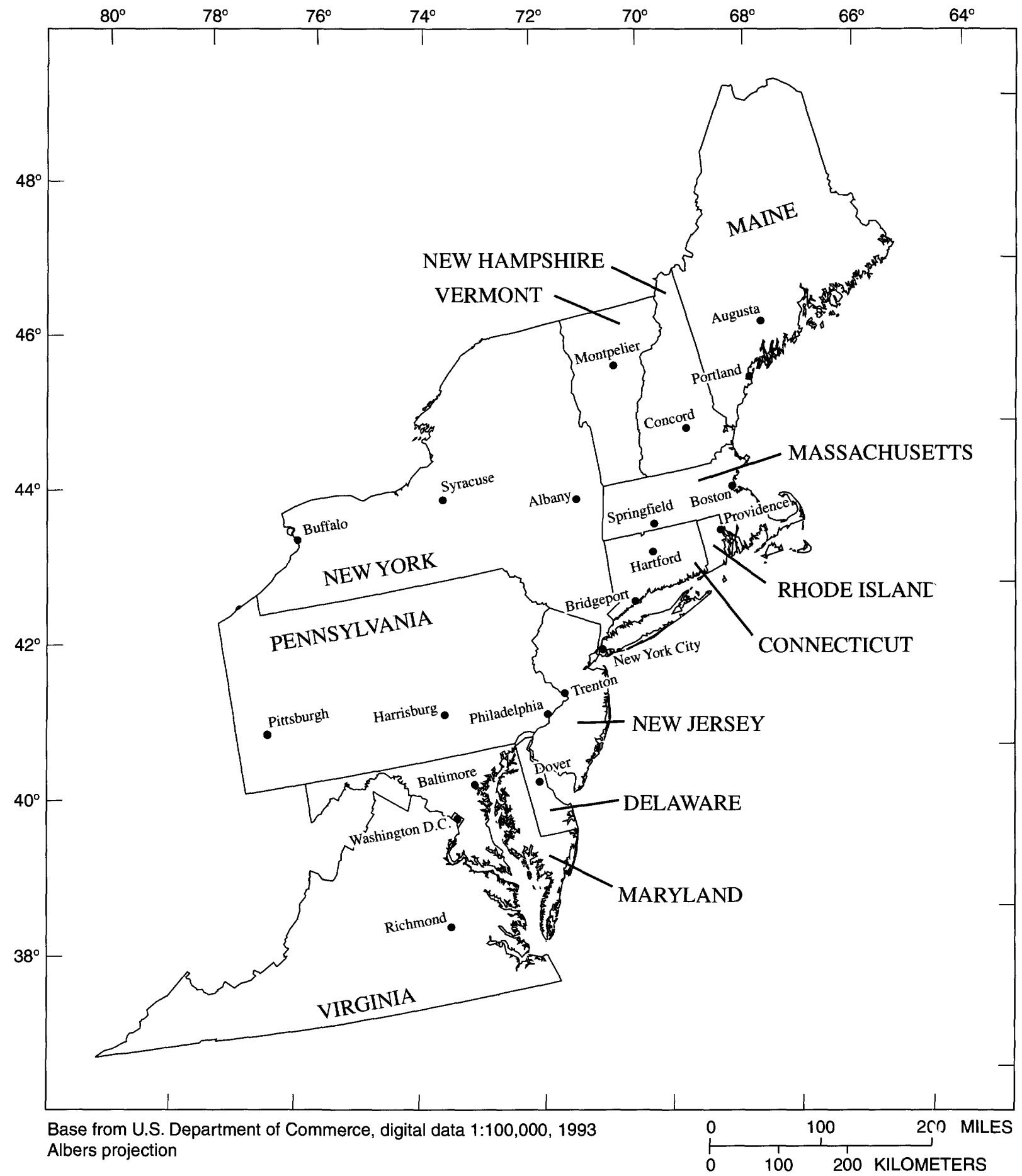

Figure 1. The 12-State study area, Northeast and Mid-Atlantic regions (from Grady and Casey, 1999, fig. 1). 
In an effort to obtain current information on the occurrence of contaminants in public drinking water regulated under the SDWA and to refine the basis for monitoring these contaminants, the USEPA has reviewed a variety of State and national databases on drinking-water quality (U.S. Environmental Protection Agency, 1999b). SDWA compliance monitoring data, including more than 10 million analyses of drinking water sampled during 1982-98 for nearly 26,000 PWSs from 12 States (including two-Massachusetts and New Jersey-in the present study), were reviewed (U.S. Environmental Protection Agency, 1999b, p. 7). Data for 64 regulated contaminants, including 21 VOCs, were compiled and analyzed. Additional data from the USEPA's Unregulated Contaminant Monitoring Information System national database on unregulated VOCs, including more than 12,000 analyses for MTBE from 4,152 PWSs, also were reviewed (U.S. Environmental Protection Agency, 1999b, p. A14-15). Generally, VOCs were reported in drinking water by about 30 percent of the PWSs inventoried. Seven of the VOCs (ethylbenzene, cis-1,2-dichloroethane, 1,1,1trichloroethane, tetrachloroethylene, trichloroethylene, vinyl chloride, and xylenes) were reportedly detected in drinking water from all States surveyed. Collectively, VOCs were detected twice as frequently in surface-water supplied PWSs than in ground-water supplied systems, and in proportionally more of the larger systems than smaller systems. MTBE was reported in drinking water by 8.3 percent of the surface-water systems and 5. 4 percent of the groundwater systems (U.S. Environmental Protection Agency, 1999b, p. A14-15).

A national study of the occurrence of VOCs in ambient ground water (Squillace, 1999; Squillace and others, 1999) reported that VOCs were most strongly associated with urban areas. Squillace and others (1999) reported 47 percent of the wells sampled in urban areas contained at least one VOC, whereas only 14 percent of the wells in rural areas contained VOCs. Chloroform (also called trichloromethane) was the most frequently detected VOC in both urban and rural areas, and MTBE was the second most frequently detected compound. The use of MTBE in OXY or RFG areas was reported to result in a 4- to 6-fold increase in MTBE detection frequency even when controlling for differences in land use (Squillace, 1999). Although VOC concentrations were generally small ( 56 percent were less than $1 \mu \mathrm{g} / \mathrm{L}$ ), it was estimated that 42 million people use ground water for drinking water in areas where at least one VOC may occur (Squillace and others, 1999).

Detections of MTBE and other VOCs have been reported previously in ambient ground water and surface water in several eastern States (Hanchar and Grady, 1994; Grady, 1997a, b; Lindsey and others, 1997; Mullaney and Grady, 1997; Stackelber 3 and others, 1997; Terracciano and O'Brien, 1997; Zogorski and others, 1997; Baehr and Zapecza, 1998; Grady and Mullaney, 1998; Baehr and others, 1999). In several earlier studies, MTBE and other VOCs also have been reported in some private or public drinking-water supplies (Grady, 1997a, b; Lindsey and others, 1997; Zogorski and others, 1997; Lince and others, 1998) in northeastern States (Connecticut, Massachusetts, New Jersey, New York, Pennsylvania, and Rhode Island). In 1998, the State of Maine conducted a statewide, statistically based, drinking-water sampling program for MTBE and other gasoline compounds in 951 randomly selected household wells or other household water supplies and 793 nontransient public water supplies (State of Maine, 1998). MTBE was detected (at a minimum reporting level of $0.1 \mu \mathrm{g} / \mathrm{L}$ ) in about 16 percent of the private and public supplies. Al vut 1 percent of the private household supplies cortained MTBE at concentrations above $35 \mu \mathrm{g} / \mathrm{L}$, which was extrapolated to represent about 1,400 to 5,20 ? household supplies statewide. The frequency of detection of MTBE was similarly associated with urban areas of the state and with areas that use RFG.

In 1999, the Northeast States for Coordinated Air Use Management (NESCAUM, 1999) prepared a State-by-State synopsis of available information on the occurrence of MTBE in ground water and drinking water for its eight member States (Connecticut, Maine, Massachusetts, New Hampshire, New Jersey, New York, Rhode Island, and Vermont). They reported that MTBE was first detected in ground water in some northeastern States during the mid-1980s, but it is now one of the most frequently detected organic-chemical contaminants in ground water in all eight States. Reported MTBE concentrations ranged up to 17,000 $\mu \mathrm{g} / \mathrm{L}$ (NESCAUM, 1999, p. 26) but were generally less than $10 \mu \mathrm{g} / \mathrm{L}$; most were below the $20-$ to $40-\mu \mathrm{g} / \mathrm{L}$ concentration range recommended by the USEPA drinking water advisory (U.S. Environmental Protection Agency, 1997). The report indicated that frequent, low-level MTBE contamination (below $10 \mu \mathrm{g} / \mathrm{L}$ ) may represent nonpoint sources such as atmospheric deposition, small surface spills, and stormwater runoff, 
whereas concentrations greater than $10 \mu \mathrm{g} / \mathrm{L}$ were more likely related to gasoline leaks and spills from underground storage tanks and pipelines (NESCAUM, 1999, p. 38).

\section{Acknowledgments}

The authors wish to acknowledge the help and cooperation provided by State and local health and environmental agencies in the 12 States, without which this study could not have been completed. Requests for data on drinking-water quality, ancillary information on PWSs, documentation of data processing and storage procedures, and review of this study's findings were promptly and professionally furnished by staff of the Connecticut Department of Public Health and Department of Environmental Protection; Delaware Department of Health and Social Services, Division of Public Health, Office of Drinking Water, and Department of Natural Resources and Environmental Control; Maine Department of Human Services, Division of Health Engineering; Maryland Department of the Environment; Massachusetts Department of Environmental Protection, Division of Water Supply; New Hampshire Department of Environmental Services, Water Supply Engineering Bureau; New Jersey Department of Environmental Protection, Division of Water Resources, Bureau of Safe Drinking Water; New York Department of Health, Bureau of Public Water Supply Protection; Pennsylvania Department of Environmental Protection, Division of Drinking Water Management; Rhode Island Department of Health; Vermont Department of Environmental Conservation, Water Supply Division; and the Virginia Department of Health, Office of Water Programs. The authors also are grateful for the assistance and cooperation provided by Michael Osinski, Rachel Sakata, and Evelyn Washington of the USEPA's Office of Ground Water and Drinking Water. The authors also acknowledge and thank Michael Osinski, Rachel Sakata, and Diana Wong, USEPA, and Gregory C. Delzer, Barbara A. Korzendorfer, Paul E. Stackelberg. William G. Wilber, and John S. Zogorski, USGS, for their insightful reviews of this report.

\section{APPROACH}

This assessment involved four tasks-(1) designing the study to include a large, representative sample of PWSs, (2) inventorying existing monitoring data on MTBE and other VOCs in drinking water collected by water systems and State and local agencies for SDWA compliance, (3) reviewing and documenting the quality, completeness, and other characteristics of the data, and (4) analyzing and interpreting the waterquality data with available ancillary data to provide information on the frequency of detection, cormentration, and geographic distribution of MTBE ant other VOCs in drinking water in the 12 States. The overall design and workplan for this assessment has been previously documented (Grady and Casey, 199?) and is not repeated here, but major elements of the design are described below for the reader's convenience. Additional information on the data inventory, documentation, and analysis are provided in subsequent sections.

\section{Study Design}

An extensive and representative inventcry of available water-quality data is required to determine the frequency of detection and the range in concentrations of MTBE and other VOCs in public drinking water for each of the 12 States. The number, size, source, and location (by State) of PWSs selected for this assessment needed to reflect the actual distribution of PWSs in the study area; however, with more than 43,000 PWSs in the 12-State area, a comprehensive review of drinking-water quality for all PWSs was not feasible.

PWSs obtain water from surface-water sources-streams, rivers, lakes, and reservoirs-and (or) ground-water sources, treat it (where required) to meet drinking-water standards, and deliver the finished water to their customers for consumption. Mo $s$ PWs provide non-residential water supplies to schcols, factories, and hospitals (nontransient noncommunity water systems (NTNCWSs)), or to campgrounds, motels, and restaurants (transient noncommunity water systems (TNCWSs)). About one-quarter of the active PWSs are community water systems (CWSs) that provide water year round to at least 25 people or have a minimum of 15 residential service connections.

Because TNCWSs, which make up the largest number of noncommunity systems, generally are not required to monitor for VOCs, and NTNCWSs generally are not the primary source of water consumed daily by their customers, only CWSs were included in the study. A stratified, random design was chosen to select participating CWSs; this design will allow information on the occurrence and distribution of VOCs in drinking water to be extrapolated to the overall population of CWSs, 
as well as statistical comparisons by State, source of water, and size of utility.

Information on the number of CWSs in the 12State study area was retrieved from the USEPA's Safe Drinking Water Information System (SDWIS) database (U.S. Environmental Protection Agency, 1995b) on December 1, 1997. This information was compiled for each State by principal source of water and population served (table 1). A total of 10,479 CWSs provided drinking water to more than 58 million people in the 12 Northeast and Mid-Atlantic States on December 1, 1997. Their geographic distribution reflects, to some extent, the size and population of each State-New York and Pennsylvania have nearly 50 percent of the
CWSs, whereas Delaware and Rhode Island have just 3 percent of the total. Table 1 points out that there are relatively few CWSs (less than 2 percent) that fall into the very large ( $>50,000$ people served) category, whereas 66 percent are small (serve 500 or fewer people); about 20 percent of the CWSs are medium size (501-3,000 served) and 13 percent are large $(₹, 001$ to 50,000 served). Although 80 percent of the $C^{r}$ VSs in the study area use ground water as their principal source of water, most of these are small systems, and ground water provided only 20 percent of the total $8,729 \mathrm{Mgal} / \mathrm{d}$ of water withdrawn for all publi- supply use in the 12 States during 1995 (Solley and others, 1998).

Table 1. Distribution of community water systems in the study area on December 1, 1997 by State, principal source of water, and population served

[Modified from Grady and Casey, 1999, table 5. Community water systems are public and private water systems that furnish water year round for domestic use to at least 25 people, or that have a minimum of 15 service connections. Data from U.S. Environmental Protection Agency's Safe Drinking Water Information System (SDWIS) database]

\begin{tabular}{|c|c|c|c|c|c|c|c|c|}
\hline \multirow[b]{3}{*}{ State } & \multicolumn{7}{|c|}{ Number of community water systems } & \multirow{3}{*}{$\begin{array}{l}\text { Percentage } \\
\text { of } \\
\text { community } \\
\text { wate- } \\
\text { systerns }\end{array}$} \\
\hline & \multicolumn{2}{|c|}{$\begin{array}{c}\text { Principal source } \\
\text { of water }\end{array}$} & \multicolumn{4}{|c|}{ Population served } & \multirow[b]{2}{*}{ Total } & \\
\hline & $\begin{array}{l}\text { Ground } \\
\text { water }\end{array}$ & $\begin{array}{c}\text { Surface } \\
\text { water }\end{array}$ & $\begin{array}{c}\text { More } \\
\text { than } \\
50,000\end{array}$ & $\begin{array}{c}3,301 \\
\text { to } \\
50,000\end{array}$ & $\begin{array}{c}501 \\
\text { to } \\
3,300\end{array}$ & $\begin{array}{c}25 \\
\text { to } \\
500\end{array}$ & & \\
\hline Connecticut & 541 & 59 & 10 & 44 & 55 & 491 & 600 & 5.7 \\
\hline Delaware & 226 & 3 & 3 & 9 & 44 & 173 & 229 & 2.2 \\
\hline Maine & 319 & 81 & 1 & 31 & 93 & 275 & 400 & 3.8 \\
\hline Maryland & 450 & 57 & 7 & 48 & 109 & 343 & 507 & 4.8 \\
\hline Massachusetts & 357 & 168 & 24 & 218 & 80 & 203 & 525 & 5.0 \\
\hline New Hampshire & 618 & 52 & 2 & 31 & 84 & 553 & 670 & 6.4 \\
\hline New Jersey & 517 & 94 & 22 & 207 & 132 & 250 & 611 & 5.8 \\
\hline New York & 1,940 & 749 & 29 & 294 & 602 & 1,764 & 2,689 & 25.7 \\
\hline Pennsylvania & 1.777 & 436 & 32 & 278 & 508 & 1,395 & 2,213 & 21.1 \\
\hline Rhode Island & 59 & 22 & 5 & 21 & 8 & 47 & 81 & 0.8 \\
\hline Vermont & 361 & 73 & 1 & 28 & 84 & 321 & 434 & 4.1 \\
\hline Virginia $^{1}$ & 1,255 & 265 & 18 & 109 & 261 & 1,132 & 1,520 & 14.5 \\
\hline $\begin{array}{l}\text { Total } \\
\text { (percent) }\end{array}$ & $\begin{array}{c}8,420 \\
(80.4)\end{array}$ & $\begin{array}{c}2,059 \\
(19.6)\end{array}$ & $\begin{array}{l}154 \\
(1.5)\end{array}$ & $\begin{array}{c}1,318 \\
(12.6)\end{array}$ & $\begin{array}{c}2,060 \\
(19.6)\end{array}$ & $\begin{array}{r}6,947 \\
(66.3)\end{array}$ & $\begin{array}{l}10,479 \\
(100)\end{array}$ & 100 \\
\hline
\end{tabular}

${ }^{1}$ Includes District of Columbia. 
Because a relatively large and representative sample was needed, $2,110 \mathrm{CWSs}$ or about 20 percent of all CWSs in the study area, were included in the targeted distribution of water systems inventoried. The targeted distribution was based on the geographic distribution of systems by State, source of water, and population served. The stratified random design (table 2) distributed the $2,110 \mathrm{CWSs}$ among the 12 States in direct proportion to their actual distribution (see table 1); for example, table 1 shows that 5.7 percent of all CWSs in the study area are in Connecticut and consequently 120 (5.7 percent) of the 2,110 targeted CWSs were allocated to Connecticut in the study design. The number of CWSs needed in Rhode Island (16), however, was augmented by 14 to obtain a total of 30 systems from that State to have sufficient numbers for valid statistical analysis of the data; the extra $14 \mathrm{CWSs}$ were allocated by source and size in the same proportions as the original 16 systems.

Retrievals were made from the SDWIS database for all active CWSs in the 12-State study area as of December 1, 1997 and the data were imported into a
Microsoft Access $@$ database. The data retrieved from SDWIS identified the CWS's public water sy:tem identification (PWSID) number, system name, address, ownership type, population served, source waters, and treatment facilities. Lists of the CWSs were organized by State, source of water, and population-served categories, and a random number generator was used to assign a selection sequence number to each $\mathrm{CV}^{\prime}$ 'S. Lists of the required number of randomly selected CWSs plus an additional number (typically 20 percent) of alternative selections were prepared for each $\$$ 'ate. For example, a list of $30 \mathrm{CWSs}$ was prepared for Rhode Island that identified the first 2 randomly numbered CWSs that served more than 50,000 people, the first 8 that served 3,001 to 50,000 people, the first 3 that served 501 to 3,000 people, and the first 17 that served 25 to 500 people. A few additional CWSs from each size category (those next in line in the random-selection sequence) also were added to the list to provide alternative selections should any of the primary selections be dropped for lack of data.

Table 2. Targeted distribution of community water systems inventoried by State, principal source of water, and population served

[From Grady and Casey, 1999, table 6. Community water systems are public and private water systems that furnish water year round for donestic use to at least 25 people, or that have a minimum of 15 service connections. Target number of community water systems is proportional to actual d:stribution, except for Rhode Island, where the number of systems was increased from 14 to 30 to obtain valid minimum number for statistical analysis]

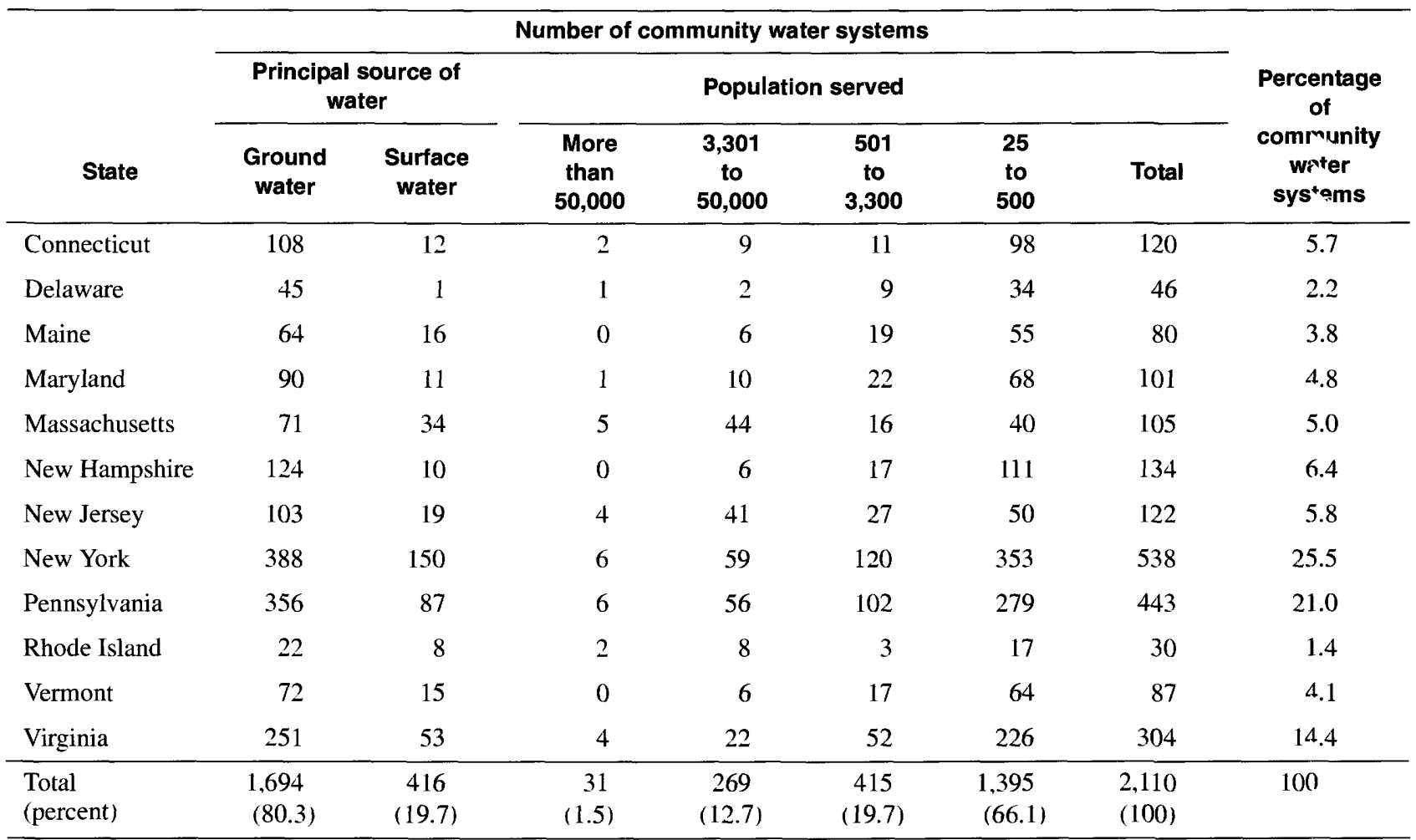


State agencies with primacy under the SDWA for implementation and oversight of compliance monitoring were contacted and requested to supply any data on VOCs collected during 1993-98 for the randomly selected CWSs in their State. When the water-quality data were received, it was reviewed to determine if the data represented surface- or ground-water sources and if the desired distribution of systems by source of water was obtained. It was noted (table 3 ) if a CWS used and sampled drinking water from both surface- and groundwater sources, but it was counted as a surface-water system with respect to fulfilling the study design. Alternative selections were used when the desired source-water distribution was not obtained or when no water-quality data were available for CWSs initially selected.

The actual distribution of 2,110 randomly selected CWSs used for this assessment is shown in table 3. In a few States, the actual distribution by source and size differs slightly from the targeted distribution. This occurred where the availability of data for CWSs that were the primary random selections was limited and alternative selections were needed to achieve the total number of CWSs targeted for that state. The net changes made to the design to accommodate data availability were four additional groundwater systems and eight fewer small systems inventoried than were targeted by the design. These changes are considered too small to introduce any systematic bias in the study design, and the actual population of $2,110 \mathrm{CWS}$ inventoried is representative of the overall distribution of CWSs in the study area. The total population served by the 2,110 CWSs, tabulated from the information coded for each system in SDWIS, is $9,637,987$ people (table 4 ) or about 16 percent of the total population served by all CWSs in the 12 -State area.

Table 3. Actual distribution of randomly selected community water systems inventoried by State, source of water, and population served

[Both includes community water systems supplied by ground-water and surface-water sources]

\begin{tabular}{|c|c|c|c|c|c|c|c|c|c|}
\hline \multirow[b]{3}{*}{ State } & \multicolumn{8}{|c|}{ Number of community water systems } & \multirow{3}{*}{$\begin{array}{c}\text { Perrentage } \\
\text { of } \\
\text { community } \\
\text { water } \\
\text { sy:tems }\end{array}$} \\
\hline & \multicolumn{3}{|c|}{ Principal source of water } & \multicolumn{4}{|c|}{ Population served } & \multirow[b]{2}{*}{ Total } & \\
\hline & $\begin{array}{c}\text { Ground } \\
\text { water }\end{array}$ & $\begin{array}{c}\text { Surface } \\
\text { water }\end{array}$ & Both & $\begin{array}{c}\text { More } \\
\text { than } \\
50,000\end{array}$ & $\begin{array}{c}3,301 \\
\text { to } \\
50,000\end{array}$ & $\begin{array}{c}501 \\
\text { to } \\
3,300\end{array}$ & $\begin{array}{c}25 \\
\text { to } \\
500\end{array}$ & & \\
\hline Connecticut & 111 & 1 & 8 & 2 & 9 & 11 & 98 & 120 & 5.7 \\
\hline Delaware & 45 & 1 & 0 & 1 & 2 & 9 & 34 & 46 & 2.2 \\
\hline Maine & 64 & 15 & 1 & 0 & 6 & 19 & 55 & 80 & 3.8 \\
\hline Maryland & 90 & 6 & 5 & 1 & 10 & 21 & 69 & 101 & 4.8 \\
\hline Massachusetts & 70 & 13 & 22 & 5 & 44 & 16 & 40 & 105 & 5.0 \\
\hline New Hampshire & 117 & 9 & 8 & 0 & 8 & 24 & 102 & 134 & 6.4 \\
\hline New Jersey & 103 & 10 & 9 & 4 & 41 & 27 & 50 & 122 & 5.8 \\
\hline New York & 387 & 103 & 48 & 6 & 59 & 120 & 353 & 538 & 25.5 \\
\hline Pennsylvania & 355 & 60 & 28 & 6 & 56 & 102 & 279 & 443 & 21.0 \\
\hline Rhode Island & 24 & 2 & 4 & 2 & 8 & 3 & 17 & 30 & 1.4 \\
\hline Vermont & 74 & 7 & 6 & 0 & 6 & 17 & 64 & 87 & 4.1 \\
\hline Virginia & 250 & 43 & 11 & 4 & 22 & 52 & 226 & 304 & 14.4 \\
\hline $\begin{array}{l}\text { Total } \\
\text { (percent) }\end{array}$ & $\begin{array}{c}1.690 \\
(80.1)\end{array}$ & $\begin{array}{c}270 \\
(12.8)\end{array}$ & $\begin{array}{l}150 \\
(7.1)\end{array}$ & $\begin{array}{c}31 \\
(1.5)\end{array}$ & $\begin{array}{c}271 \\
(12.8)\end{array}$ & $\begin{array}{c}421 \\
(19.9)\end{array}$ & $\begin{array}{c}1,387 \\
(65.7)\end{array}$ & 2,110 & 107 \\
\hline
\end{tabular}


Table 4. Population served by community water systems in the study area

[CWS, community water systems]

\begin{tabular}{|c|c|c|c|}
\hline State & $\begin{array}{c}\text { Population served by } \\
\text { all CWSs }\end{array}$ & $\begin{array}{l}\text { Population served by } \\
\text { randomly selected CWSs }\end{array}$ & $\begin{array}{c}\text { Percentage of } \\
\text { population served by } \\
\text { randomly selected CWS }\end{array}$ \\
\hline Connecticut & $2,611,549$ & 959,421 & 36.7 \\
\hline Delaware & 678,296 & 186,774 & 27.5 \\
\hline Maine & 590,953 & 118,370 & 20.0 \\
\hline Maryland & $4,548,230$ & 196,238 & 4.3 \\
\hline Massachusetts & $7,815,920$ & $1,347,538$ & 17.2 \\
\hline New Hampshire & 729,939 & 106,344 & 14.6 \\
\hline New Jersey & $7,629,001$ & $1,810.899$ & 23.7 \\
\hline New York & $16,594,651$ & $1,847,884$ & 11.1 \\
\hline Pennsylvania & $10,512,736$ & $1,568,755$ & 14.9 \\
\hline Rhode Island & 970,231 & 372,523 & 38.4 \\
\hline Vermont & 470,563 & 96,079 & 20.4 \\
\hline Virginia $^{1}$ & $5,297,854$ & $1,027,162$ & 19.4 \\
\hline Total & $58,449,923$ & $9,637,987$ & 16.5 \\
\hline
\end{tabular}

The distribution of 4.427 ground-water sources (wells and springs) and 595 surface-water sources (intakes from reservoirs, lakes, and streams) known to provide dinking water to the 2,110 randomly selected CWSs is shown in figure 2. Identification of the 5,022 sources and their locations were obtained from the SDWIS database, State datasets, USGS water-use data, and the CWSs themselves. Sources shown in figure 2 include only those that are known to provide water to the randomly selected CWSs (or are sources to systems that sell water to the randomly supplied CWSs) and for which locational data (latitude and longitude of the surface-water intake or wellhead) are presently available. Consequently, figure 2 does not include all possible sources of water for the 2,110 CWSs, and there may be water samples in the 12-State database that were obtained from sources not shown in this figure. An extensive effort was made to collect as much information on sources as could be accomplished within the resources of this study, and the authors feel that the distribution shown in figure 2 includes the majority of sources associated with VOC analyses in the water-quality data.

\section{Data Inventory}

Grady and Casey (1999) inventoried the availability of data on VOCs for public drinking water in each of the 12 States in the study area. Information based on telephone surveys of State health and watersupply agencies indicated that data for some VOCs in drinking water were available in State comp'ter databases for 11 of the 12 States; Connecticut ms intains its drinking-water-quality data in paper files only. Electronic data were requested and received from the 11 States; data for Connecticut were obtained by conducting a review of files for the selected CWSs and scanning paper copies of drinking-water analyses into an electronic database. Some states elected to provide data for all PWSs or more than the requested randomly selected CWSs. Five states provided data that preceded the requested period of record, with the oldest VOC data dating back to 1978 and the oldest MTPE data dating back to 1987 . 


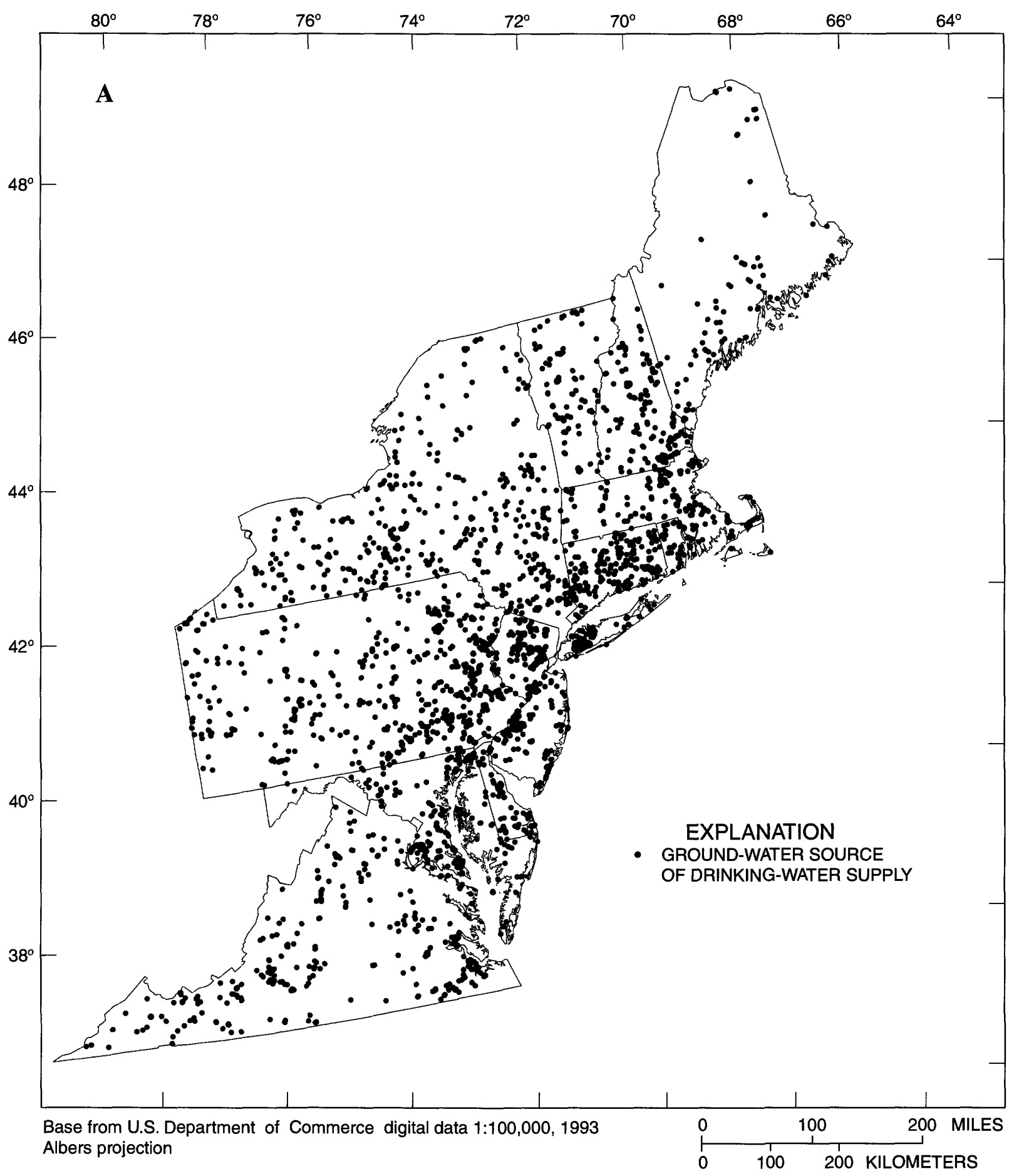

Figure 2. Drinking-water sources of water for randomly selected community water systems in the study area showing (A) ground-water sources and (B) surface-water sources. 


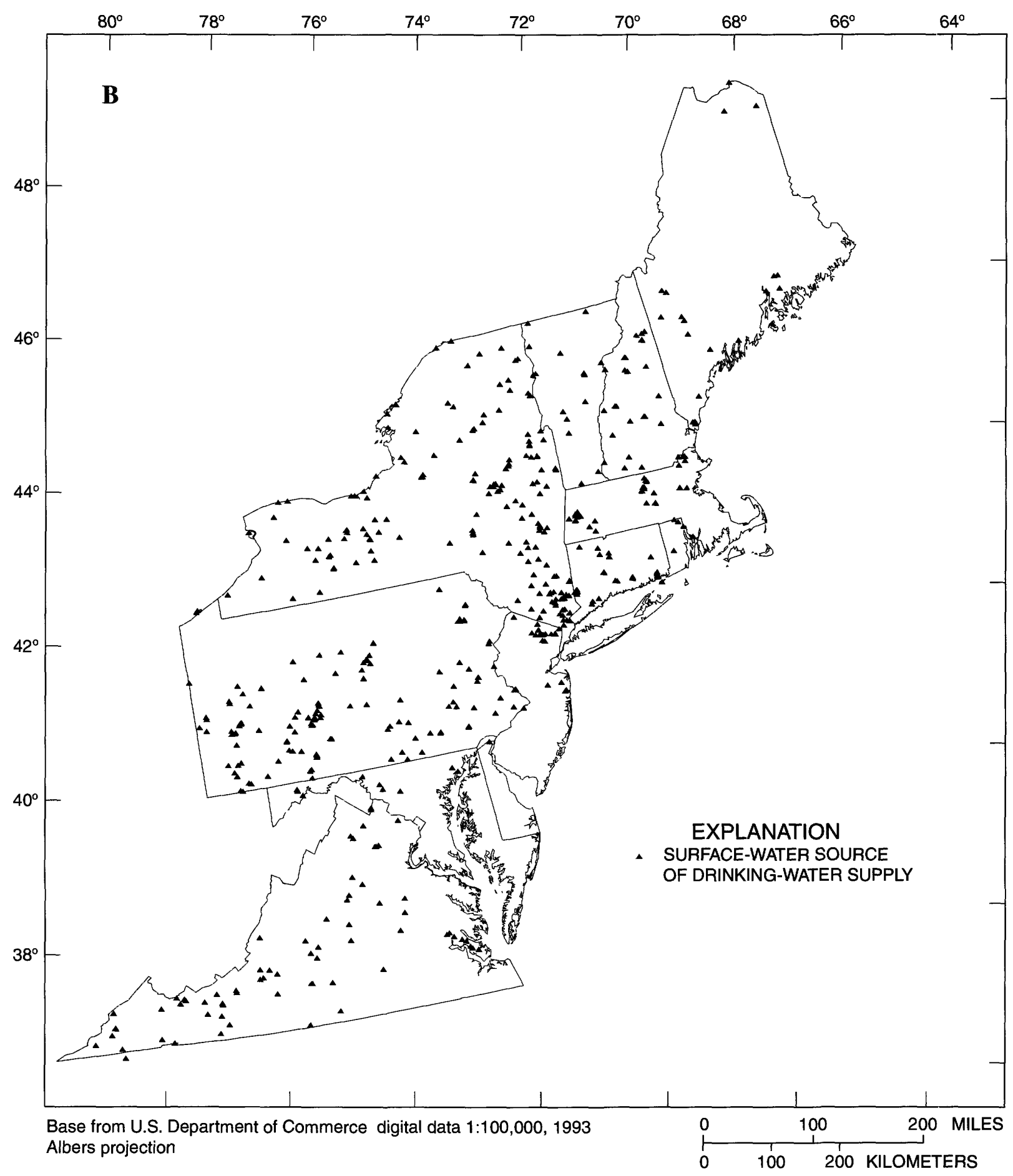

Figure 2. Drinking-water sources of water for randomly selected community water systems in the study area showing (A) ground-water sources and (B) surface-water sources.--Continued 
The availability of data on VOCs and, specifically, MTBE in drinking water for the 12 States compiled for this study is summarized in table 5. In total, more than 56,000 analyses for VOCs in drinking water for the period 1978-98 were compiled for nearly 8,000 PWSs in the study area; these included 16,717 MTBE analyses for the period 1987-98, representing more than 4,000 PWSs in the region. Screening the data for the 2,110 randomly selected CWSs and the 1993-98 time period resulted in more than $21,000 \mathrm{VOC}$ analyses available for this assessment. The number of analytes tested for in any given analysis ranged from 1 to as many as 70 VOCs. The analytical coverage also differed substantially from state to state; Pennsylvania and Vermont reported the fewest VOC analyte` (46) whereas New Jersey reported the most (75). Ten States provided some MTBE data, but none were available for any drinking water systems in Delaware and Pennsylvania. Consequently, only 1,194 of the 2,110 randomly selected CWSs reported one or more MTBE analysis, with a total of 5,510 analyses that included the gasoline oxygenate. In total, $84 \mathrm{VOC}$ analytes, includirg isomers ( $o-, m$-, and $p$-xylene), sums of isome"s (total xylenes, total dichlorobenzenes, cis- \& trans-1,3dichloropropene) or the sum of other related VOCs (total trihalomethanes), were reported in at least one analysis of drinking water compiled for this stıdy.

Table 5. Availability of data on volatile organic compounds in drinking water for the study area, 1978-98

[PWSs, public water systems: CWSs, community water systems; VOC, volatile organic compound; MTBE, methyl tert-butyl ether]

\begin{tabular}{|c|c|c|c|c|c|c|}
\hline State & $\begin{array}{l}\text { Number of } \\
\text { active PWSs } \\
\text { (and CWSs) }\end{array}$ & $\begin{array}{l}\text { Number of } \\
\text { PWSs with } \\
\text { any VOC data } \\
\text { (number of } \\
\text { analyses) }\end{array}$ & $\begin{array}{l}\text { Number of } \\
\text { randomly } \\
\text { selected } \\
\text { CWSs with } \\
\text { any VOC data } \\
\text { (number of } \\
\text { analyses) }\end{array}$ & $\begin{array}{c}\text { Number of } \\
\text { VOC } \\
\text { analytes } \\
\text { reported }\end{array}$ & $\begin{array}{l}\text { Number of } \\
\text { PWSs with } \\
\text { MTBE data } \\
\text { (number of } \\
\text { analyses) }\end{array}$ & $\begin{array}{l}\text { Number of } \\
\text { randorrly } \\
\text { selecte.d } \\
\text { CWSs with } \\
\text { MTBE d-ta } \\
\text { (number of } \\
\text { analyse.s) }\end{array}$ \\
\hline Connecticut & $\begin{array}{l}4,460 \\
(600)\end{array}$ & $\begin{array}{r}122 \\
(694)\end{array}$ & $\begin{array}{r}120 \\
(682)\end{array}$ & 70 & $\begin{array}{r}122 \\
(514)\end{array}$ & $\begin{array}{r}120 \\
(507)\end{array}$ \\
\hline Delaware & $\begin{array}{r}564 \\
(229)\end{array}$ & $\begin{array}{r}48 \\
(225)\end{array}$ & $\begin{array}{r}46 \\
(195)\end{array}$ & 62 & $\begin{array}{r}0 \\
(0)\end{array}$ & $\begin{array}{r}0 \\
(0)\end{array}$ \\
\hline Maine & $\begin{array}{l}1.898 \\
(400)\end{array}$ & $\begin{array}{r}346 \\
(2,941)\end{array}$ & $\begin{array}{r}80 \\
(665)\end{array}$ & 58 & $\begin{array}{r}216 \\
(396)\end{array}$ & $\begin{array}{r}55 \\
(122)\end{array}$ \\
\hline Maryland & $\begin{array}{l}3,123 \\
(507)\end{array}$ & $\begin{array}{r}498 \\
(2,947)\end{array}$ & $\begin{array}{r}101 \\
(555)\end{array}$ & 63 & $\begin{array}{r}494 \\
(2,438)\end{array}$ & $\begin{array}{r}101 \\
(456)\end{array}$ \\
\hline Massachusetts & $\begin{array}{l}1,629 \\
(525)\end{array}$ & $\begin{array}{r}845 \\
(5,197)\end{array}$ & $\begin{array}{r}105 \\
(1,513)\end{array}$ & 64 & $\begin{array}{r}75 \\
(270)\end{array}$ & $\begin{array}{r}75 \\
(277)\end{array}$ \\
\hline New Hampshire & $\begin{array}{l}2,071 \\
(670)\end{array}$ & $\begin{array}{r}146 \\
(453)\end{array}$ & $\begin{array}{r}134 \\
(453)\end{array}$ & 69 & $\begin{array}{r}130 \\
(387)\end{array}$ & $\begin{array}{r}130 \\
(387)\end{array}$ \\
\hline New Jersey & $\begin{array}{l}4,740 \\
(611)\end{array}$ & $\begin{array}{r}1,436 \\
(13,336)\end{array}$ & $\begin{array}{r}122 \\
(2,287)\end{array}$ & 75 & $\begin{array}{r}1,095 \\
(3,783)\end{array}$ & $\begin{array}{r}65 \\
(510)\end{array}$ \\
\hline New York & $\begin{array}{r}9,129 \\
(2,689)\end{array}$ & $\begin{array}{r}1,583 \\
(15,004)\end{array}$ & $\begin{array}{r}538 \\
(6,909)\end{array}$ & 67 & $\begin{array}{r}351 \\
(2,442)\end{array}$ & $\begin{array}{r}241 \\
(1,83 ?)\end{array}$ \\
\hline Pennsylvania & $\begin{array}{c}10,249 \\
(2,213)\end{array}$ & $\begin{array}{r}459 \\
(5,746)\end{array}$ & $\begin{array}{r}443 \\
(5,746)\end{array}$ & 46 & $\begin{array}{r}0 \\
(0)\end{array}$ & $\begin{array}{r}0 \\
(0)\end{array}$ \\
\hline Rhode Island & $\begin{array}{l}451 \\
(81)\end{array}$ & $\begin{array}{r}490 \\
(3,571)\end{array}$ & $\begin{array}{r}30 \\
(1,273)\end{array}$ & 59 & $\begin{array}{r}251 \\
(3,189)\end{array}$ & $\begin{array}{r}30 \\
(511)\end{array}$ \\
\hline Vermont & $\begin{array}{l}1,270 \\
(434)\end{array}$ & $\begin{array}{r}597 \\
(2,487)\end{array}$ & $\begin{array}{r}87 \\
(399)\end{array}$ & 46 & $\begin{array}{r}89 \\
(228)\end{array}$ & $\begin{array}{r}75 \\
(18 \Lambda)\end{array}$ \\
\hline Virginia & $\begin{array}{r}4,241 \\
(1,520)\end{array}$ & $\begin{array}{r}1,376 \\
(4,206)\end{array}$ & $\begin{array}{r}304 \\
(958)\end{array}$ & 61 & $\begin{array}{r}1,354 \\
(3,070)\end{array}$ & $\begin{array}{r}372 \\
(724)\end{array}$ \\
\hline Total & $\begin{array}{r}43,825 \\
(10,479)\end{array}$ & $\begin{array}{r}7,946 \\
(56,807)\end{array}$ & $\begin{array}{r}2,110 \\
(21,635)\end{array}$ & 84 & $\begin{array}{r}4,177 \\
(16,717)\end{array}$ & $\begin{array}{r}1,194 \\
(5,510)\end{array}$ \\
\hline
\end{tabular}

\footnotetext{
'Data from U.S. Environmental Protection Agency's Safe Drinking Water Information System as of December 1, 1997.
} 
Although the overall time period examined for this study is 1993-98, the actual period of record for data on VOCs, and especially MTBE, from each of the 12 States varied considerably (table 6). Massachusetts and Rhode Island, for example, provided VOC and MTBE data that spanned the 6-year period, whereas electronic data for Virginia were only available for 13 months in 1997 and 1998. New Jersey and Maine provided 6 years of electronic VOC data but their MTBE data were limited to a much shorter period in 1997-98. Just three States-Connecticut, Massachusetts, and Rhode Island - provided data for MTBE that predated the introduction of RFG in 1995. Differences in the ending month of the period of record among the 12 States are largely an artifact of when this study requested and obtained the analytical data. SDWA compliance monitoring has continued through the present in all 12 States.

The 84 VOCs included in at least one analysis of drinking water for the randomly selected CWSs are identified in appendix 1. Chemical analyses for 21 regulated and 21 unregulated VOCs (appendix 1) are determined routinely for most drinking-water samples under provisions of the SDWA. Additionally, analysis for 14 other unregulated VOCs (appendix 1) may be required at the discretion of individual States. States have broad discretion in granting waivers to monitoring requirements; Pennsylvania, for example, only requires analysis for the 21 regulated VOCs at most CWSs where previous monitoring (largely prior to 1993) demonstrated the lack of occurrence of unregulated VOCs. Consequently, the suite of VOCs included in the drinking-water data is variable and, beyond the 21 regulated chemicals, is not consistent among the 12 States (see appendix 2). Appendix 2 also includes data for five "total" VOCs-dichlorobenzenes, 1,3-dichloropropene, trihalomethanes, $m$ - \& $p$-xylenes, and xylenes-that were not reported consistently by all states. These "total" values were calculated as the sum of the isomer or component compounds (for example, the sum of the $m-, o-$, and $p$-dichlorobenzene analytical determinations) when one or more of the components were reported for any specific sample. The calculated "totals" were determined to afford the largest possible sample populations for these VOCs and to facilitate comparisons among the states.
Chemical analyses for VOCs sometimes also included two additional regulated compounds, the fumigants EDB and DBCP, and(or) several nonregulated chemicals (for example tetrahydrofuran; see appendix 1) that can be detected and identified by USEPA drinking-water methods 502.2 and 524.2. These compounds generally are reported in separate analyses for pesticides or other synthetic organic chemicals and were not widely reported with the State's VOC data. Eight of the nonregulated VOCs included in the data received from some States were analyzed for by less than $10 \mathrm{CWSs}$.

MTBE is not presently regulated under the SDWA, and compliance monitoring of public drinking water for MTBE is not required. Most of the 12 States studied, however, have issued drinking-water regulations or guidelines for MTBE that require or encourage PWSs in their purview to monitor for it. Some State or local agencies or individual water systems also have collected MTBE data as part of their general drinkingwater monitoring activities or specifically when sampling PWSs in areas where MTBE might be expected to occur (for example, near gasoline stations). For these reasons, the data inventory contains MTBE data for more than half of the designed 2,110 CWSs with at least one MTBE analysis available for 1,194 CWSs in 10 of the 12 States (see table 5); two States (Delaware and Pennsylvania) reported no data on MTBE in drinking water.

Although most VOCs have numerous uses in industry, commerce, and household applications, there is no comprehensive National database with information available on the use of VOCs. The authors' interpretation of the primary use or source of each of the 84 VOCs included in the data compilation also is included in appendix 1 . They were classified among six predominant use categories that may have the most relevance to their occurrence in drinking water-(1) disinfectant by-products, (2) gasoline components, (3) solvents, (4) chemicals used in the synthesis of other organic compounds, (5) refrigerants, and (6) fumigants. The purpose of identifying a predominate use of VOCs is to facilitate comparisons of their occurrence and distribution in drinking water but does not imply that the use is the only possible source for the VOCs reported in drinking water. Classification of VOCs into principal use categories is based on information developed by Bender and others (1999). 
Table 6. Period of record for data compiled on volatile organic compounds and methyl tert-butyl ether in drinking water from randomly selected community water systems in the study area

[VOCs, volatile organic compounds; MTBE, methyl tert-butyl ether]

\begin{tabular}{|c|c|c|c|c|c|c|c|}
\hline & & \multicolumn{6}{|c|}{ Period of record } \\
\hline State & Analyte & 1993 & 1994 & 1995 & 1996 & 1997 & 1998 \\
\hline \multirow{2}{*}{ Connecticut } & VOCs & & & & & & \\
\hline & MTBE & & & & & & \\
\hline \multirow{2}{*}{ Delaware } & VOCs & & & & & & \\
\hline & MTBE & & & & & & \\
\hline \multirow{2}{*}{ Maine } & VOCs & & & & & & \\
\hline & MTBE & & & & & & \\
\hline \multirow{2}{*}{ Maryland } & VOCs & & & & & & \\
\hline & MTBE & & & & & & \\
\hline \multirow{2}{*}{ Massachusetts } & VOCs & & & & & & \\
\hline & MTBE & & & & & & \\
\hline \multirow{2}{*}{$\begin{array}{l}\text { New Hamp- } \\
\text { shire }\end{array}$} & VOCs & & & & & & \\
\hline & MTBE & & & & & & \\
\hline \multirow{2}{*}{ New Jersey } & VOCs & & & & & & \\
\hline & MTBE & & & & & & \\
\hline \multirow{2}{*}{ New York } & VOCs & & & & & & \\
\hline & MTBE & & & & & & \\
\hline \multirow{2}{*}{ Pennsylvania } & VOCs & & & & & & \\
\hline & MTBE & & & & & & \\
\hline \multirow{2}{*}{ Rhode Island } & VOCs & & & & & & \\
\hline & MTBE & & & & & & \\
\hline \multirow{2}{*}{ Vermont } & VOCs & & & & & & \\
\hline & MTBE & & & & & & \\
\hline \multirow{2}{*}{ Virginia } & VOCs & & & & & & \\
\hline & MTBE & & & & & & \\
\hline
\end{tabular}




\section{Data Documentation}

Because the data compiled for this study were obtained from 12 different States with different data reporting and management protocols, considerable review, editing, formatting, and documentation was needed. Electronic data obtained from the States were received in a variety of formats and included different data elements, codes, and levels of documentation. The data from each State were reformatted into the project's Microsoft Access $\odot$ database so that consistent and valid comparisons could be made among the various State's data, and the occurrence and distribution of VOCs in drinking water could be described on a regional level. Each State's data were reviewed to ensure that it contained several basic elements considered to be necessary for use in this analysis. These included the PWSID, source locations (latitude and longitude), source-water type, population served, sample identification, analyte identification, and analytical results.

Every CWS is identified by a unique, 9-digit, alphanumeric SDWIS PWSID (for example, CT0040011). This identifier, or at least the numeric component of the SDWIS PWSID, was used by each State as an identifier with every water-quality analysis. The system name also was coded in all State databases. State identifiers and system name were cross-referenced to data from SDWIS retrievals to verify system identification. Locational information, specifically latitude and longitude coordinates for source waters (wells and surface-water intakes), were poorly documented in the State data as a whole. Until recently, providing an accurate latitude and longitude for all sources was not required of States or water systems as they filed the information requested for the SDWIS database. Some locational information was available in SDWIS, coded with the State drinking-water data, or was obtained from State environmental agencies. Where no information was available from these sources, efforts were made to obtain source locations by using interactive mapping software (DeLorme, 1999) to locate the street address provided from SDWIS, State data, or by contacting the CWSs. Through this effort, latitude and longitude coordinates were assembled for more than 5,000 individual sources supplying the 2,110 randomly selected CWSs.

Information on the source of water sampled is needed to determine if there are differences in the occurrence of VOCs and the vulnerability of water supplies to VOC contaminants between surface- and ground-water systems and between surficial unconfined aquifers and deeper confined aquifers. $\mathrm{I}^{\mathrm{J}} \mathrm{Owever}$ the source of the drinking-water sample was not always identified in each State's data. Most drinking-water analyses (about 85 percent), had information coded with the analytical data that could be used to identify whether the sample was from a ground-water or a surface-water source. For some samples, sucl as those collected from locations within the distributic n system of CWSs with both ground- and surface-water sources, the source was unidentified and could represent a blend of sources. Additionally, some drinking-water analyses were for samples composited from several scurces or even from multiple systems. Consequently, tl is study could not interpret the drinking-water data based on an unequivocal understanding of the source of the drinking-water associated with each sample.

The analytical data were designated as either representing CWSs exclusively supplied by groundwater sources, those exclusively supplied by surfacewater sources, or as data for CWSs with both groundand surface-water sources based on the information coded with the analytical data from the State database, or on information from SDWIS regarding the water sources that supply each of the 2,110 randomly selected CWSs. SDWIS classifies a CWS as a surface-water system if it has any surface-water sources, or purchases water from a system that has surface-water sources. Ground-water supplied systems include those supplied exclusively by ground-water sources, ground-water sources under the influence of surface water (U.S. Environmental Protection Agency, 1994), or water purchased from CWSs supplied exclusively f"om ground water. For this study, the source category of "both surface-water and ground-water sources" was used for samples from systems with both types of source waters even when information coded with the analytical data indicated the type of source water sampled.

Information on the population served $\mathrm{t} v \mathrm{CWS}$ is needed to estimate potential human exposure to VOCs from drinking water. Most States provided information on the number of people served by ea? $\mathrm{CWS}$ or the information was obtained from the December 1997 SDWIS retrieval used to design the survey. The SDWIS population-served data agreed in most cases with the information provided by the States, but it is uncertain how often this data field is updated or how recently the States make the updates available in the 
SDWIS database. No information was available from the State data or from SDWIS that documented any historical changes in population served that could be correlated with specific sample dates.

Other useful sample-specific information was included with the analytical data from some States, but the consistency of reporting and the content of what was reported varied considerably from state to state. Several States reported a unique sample or laboratory identification number that was used to reference specific analytical results to specific sources, sample locations, and (or) sample temporal sequences. Lack of a unique sample indentifier confounded efforts to resolve specific analytical results for some CWSs when apparent duplicate samples were collected from the same source or location on the same date. A sample location (name or number of a specific site where a sample was collected, for example, well number 1 , kitchen tap), sample location type (well head or intake, point of entry to the water distribution system, distribution system sample), or sample type (raw, finished, routine, special, duplicate, confirmation) was frequently, but not always, provided. Information on which laboratory performed the analysis, the USEPAapproved analytical methods used, and the date of the analysis also was provided by some States.

Differences in the manner in which States identified and reported the suite of VOC analytes that were determined for each drinking-water analysis caused the greatest difficulties in compiling the 12-State drinkingwater database. A few States provided the analytical results in an unambiguous "crosstable" format, with each row representing a specific sample and each column a specific analyte. With this format, the results for every analytical observation were coded as a numerical concentration value if detected, or with a "less than" symbol and the analytical detection level (for example, " $<0.05$ "), a zero, or some other nonnumeric indication that the analyte was not observed (that is, not detected "ND", or below detection levels "BDL") in the water sample. Most States, however, stored and transmitted their data in a format designed to minimize the volume of data. In this data format, only detectable concentrations were identified. If no contaminants were detected in a sample, some abbreviated indication of the multiple analytes included in the analysis would be coded (for example, "VOCs"), or the analytical method used would be indicated (for example, USEPA Drinking Water Method "502.2" or "524.2"). When this method was used, documentation was needed from the States as to what analytes were explicitly included in the coded methods for the period of record reported, and what method detection level (MDL) or minimum reporting level (MRL) was applicable for each analyte. Some States provided $\varepsilon$ reference table that included such documentation along with the transmitted data. For some States, this info"mation could only be obtained from contacting laboratory or other staff familiar with their State's historical data collection, analysis, and management procedures. With this level of documentation, it was possible to populate crosstables in the project's database that code a less than MDL or MRL value, ND, or BDL for every observation of the suite of VOC analytes without a syecified detectable concentration.

Additional uncertainty was associated with the actual quantification levels of VOC analytes and reported concentrations for some States. Laboratory quantification levels are generally contaminant and method specific, and documentation of the MDL or MRL was often missing in the State data. If documentation could not be obtained from the State, the quantification levels could sometimes be surmised from the analytical data, particularly if some "less than" values were coded and there were sufficient numbers of observations at detectable concentrations. For other c nalytes, information on the method and the USEPA-sp?.cified practical quantification level (PQL) for each analyte served to estimate the MRL; for most VOCs, this was equal to $0.5 \mu \mathrm{g} / \mathrm{L}$. Not all data were reported in the same concentration units, however, even for data from the same State. For this study, any data coded as "parts per million" or "milligrams per liter" were converted to micrograms per liter. Any data values that were extreme outliers were reviewed to determine if the concentration units were correctly reported. $T$-is was accomplished where possible by obtaining a paper copy of the analytical results for those samples from the States and comparing the concentration values coded in the electronic data to information in the laboratory report for that sample. Selected analyse for about 10 percent of all CWSs were confirmed by comparison to the original laboratory analytical report, and few discrepancies were uncovered.

Although documentation of analytical coverage and reporting levels for most VOC analytes, particularly the regulated compounds, was not too difficult, documentation of MTBE analyses was more froblematic. Several States did not report MTBE when the oxygenate was analyzed for but not detected ir a water 
sample. For the States where all or most analyses are performed by the State laboratory (Maine, New Hampshire, and Virginia), it was generally possible to determine a date when MTBE was included in the laboratory's VOC method. All samples subsequent to that date that did not specifically contain detectable concentrations of MTBE were assumed to have been analyzed for that compound but not reported. It is possible that this assumption may be wrong for a small number of samples and if so, then MTBE detection frequencies determined for those States may be slightly underestimated. For other States where numerous private laboratories perform the bulk of the drinkingwater analyses (Massachusetts and Vermont), a review of the State's paper files on the drinking-water analyses was conducted to confirm if MTBE was among the VOC analytes. However, paper records for many of the samples included in the electronic database could not be located. To the extent that some randomly selected CWSs in these States may have had drinking-water samples analyzed for MTBE without detection, but no confirming paper records could be located and consequently these systems were excluded from the MTBE analysis, then MTBE detection frequencies determined for those States may be slightly overestimated.

Additional ancillary data are needed to extend the value of the information on drinking-water quality beyond occurrence and distribution of VOCs. Information on the location, capacity, and processes used at filtration and treatment plants, the geographic boundaries and characteristics of the water-distribution area, actual population served by each source or segment of the distribution system, and quantity of water delivered by suppliers could be used to more fully explain and compare the frequency of detection and concentration of VOCs in drinking water. For surface-water sources, specific information on the depth, size, and operation of intakes, the number, type, and location of any discharges to receiving surface-water bodies that are source waters for CWSs; land-use patterns in source surface-water basins; and locations of upwind releases of VOCs to the atmosphere and other potential VOC sources would be useful. For ground-water sources, specific information on the supply well and the producing aquifer (depth, diameter, water level, depth to the open interval, other construction characteristics of the well, pump type, well yield, and contributing area to the well), as well as land use, population density, locations of known or potential VOC sources (gasoline stations, dry cleaners, other commercial and industrial users), and other cultural, demographic information for the area adjacent to the well could be obtained. Although some of these data were included with the analytical data or were obtained from other sources during the inventory of CWSs for a few States, these data elements were not widely available and were inconsistently documented in the State data and the SDWIS database. It was possible to obtain some ancillary data elements, particularly the location of wells and surface-water intakes with respect to $\mathrm{OX}^{\mathrm{r}} / \mathrm{RFG-}$ fuel areas and urban land use, from regional GIS coverages. The lack of consistent, verified ancillary data for many CWSs, however, generally limited the data analysis in this study to determination and description of VOC detection frequencies and concentrations.

\section{Data Analysis}

Statistical summaries of the data, presented in tabular and graphical formats in this report, are used to describe the occurrence and distribution of MTBE and VOCs in drinking water. Descriptive statistics include number of samples, number of detections, the frequency of analysis (percentage of analyses that include analyte and percentage of CWSs with analyses for each specific analyte), the frequency of detection (percentage of CWSs with detections), detectable concentration range, and medians of detected VOC concentrations. Although the percentage of samples with detections is summarized in appendix 3 for the reader's information, the authors would caution that these results are often skewed by the highly variable number of samples from each CWS. Also, onse a contaminant has been detected at a CWS, repetitive sampling and detections are often reported. Unless otherwise indicated, when median concentrations are reported, the median concentration for all detections at each CWS was determined and used to calculate the median concentration reported in text and tables in this report. Medians of detected concentrations provide a positively biased indication of actual median VOC concentrations because samples with concentrations below analytical reporting levels are not included, but this statistic is useful when comparing concertrations among highly censored analytes.

The occurrence of VOCs, as defined by the frequency of detection (or drinking-water criteria exceedance), was calculated by dividing the number of CWSs reporting detections (or number of CWSs with exceedances) by the number of CWSs with analyses 
and multiplying by 100 . A CWS is counted as having had a VOC detection if a measurable concentration of an analyte was reported in any one or more water sample(s) associated with any source or sample location for that CWS. For the statistic "frequency of detection at any reporting level" used in this report, no effort was made to censor data with multiple reporting levels. When the frequency of detection is censored at a specific reporting level (for example, $1.0 \mu \mathrm{g} / \mathrm{L}$ ) all samples reported as non-detections at higher reporting levels (for example, $<2.0 \mu \mathrm{g} / \mathrm{L},<5.0 \mu \mathrm{g} / \mathrm{L}$, etc.) are deleted, all samples with lower reporting levels (for example, $<0.5 \mu \mathrm{g} / \mathrm{L},<0.1 \mu \mathrm{g} / \mathrm{L}$ ) are converted to $<1.0$ $\mu \mathrm{g} / \mathrm{L}$, and all observations with reported concentrations that are less than $1.0 \mu \mathrm{g} / \mathrm{L}$ (for example, $0.9 \mu \mathrm{g} / \mathrm{L}, 0.5$ $\mu \mathrm{g} / \mathrm{L}$, etc.) are converted to $<1.0 \mu \mathrm{g} / \mathrm{L}$ values.

Censoring the data at specific reporting levels generally eliminates some CWSs from the analysis; this affect is most apparent at the $0.5-\mu \mathrm{g} / \mathrm{L}$ reporting level.

Descriptive and nonparametric statistics, histograms, cumulative frequency plots, and boxplots (Helsel and Hirsch, 1992) are used in this report to describe the frequency of detection and concentration of MTBE and other VOCs in drinking water relative to the total number of CWSs and the total number of drinking-water samples for the 12-State region collectively, and for each individual State. The data also are summarized to present the occurrence and distribution in relation to the source of drinking water and to each population-served category. Estimates of the total number of people potentially exposed to individual compounds and selected groups of VOCs were made on the basis of data on the actual population served by those CWSs reporting VOC detections. Maps were prepared showing the locations of drinking-water sources (wells and surface-water intakes) for CWSs that have reported detectable concentrations MTBE and other VOCs in relation to oxygenated gasoline use and (or) urban land use. Where appropriate, a variety of hypothesis tests, including contingency-table tests (Pearson's chi-square test with Yates' continuity correction), Kruskal-Wallis tests, and the Wilcoxon signed rank test (Helsel and Hirsch, 1992), were conducted to test for relations between the frequency of detection or concentrations of VOCs and anthropogenic factors such as land use, population density, and the distribution of high MTBE-use areas.

Contingency-table tests are used in this report because the highly censored VOC analytical data largely precludes analysis by hypothesis tests that evaluate continuous variables. Contingency tables measure the association between two discrete. categorical variables, for example, the probability of detecting a VOC (verses the probability of nondetectior) related to a type of land use or the presence or absence of some other anthropogenic factor. The data are arrarged into a matrix of rows and columns-with no natural ordering-and the distribution of data among the categories is tested to determine if the row classification is independent of the column using the cri-square distribution (Helsel and Hirsch, 1992). As with other statistical tests used in this report, the results of the contingency tests are expressed by the "p-value" or the significance level attained by the data; for this report, the null hypothesis is rejected and the two variables are determined to be significantly related at p-values less than 0.05 (95-percent confidence level). When the variables are found to be dependent or related, however, it is not necessarily implied that one variable causes the observed response in the second variable.

\section{OCCURRENCE AND DISTRIBUTIOI" OF VOCS IN DRINKING WATER}

An overview of the occurrence and distribution of VOCs in drinking water is presented here as an introduction to more detailed findings presented in subsequent sections of this report. It is intended to summarize the overall status of the quality of drinking water in the 12-State region with respect to VOC contaminants at any reporting level, and to provide a reference for additional observations on the occurrence and distribution of specific analytes by State, source, size, or other characteristics of the CWSs. Detailed summaries of the frequency of detection at srocific reporting levels and the concentrations of all VOC analytes reported in the available data are included in appendix 3 and in the text, tables, and figures in subsequent sections of this report.

Data compiled for the 2,110 randomly selected CWSs in the 12-State study area included 21,635 analyses of drinking-water samples collected from 199398. Of the 84 VOC analytes tested for in some drinking water (see appendixes 1 and 2), 64 compounds (table 7) have been reported at a detectable concentrat ${ }^{\prime} n$ in at least 1 sample. A total of 8,955 of the 21,635 analyses assembled for this study (41 percent) reported at least 1 of the 64 VOCs at a detectable concentraticn. VOCs have been reported at detectable concentrations 19,625 times in drinking-water samples. 
Table 7. Volatile organic compounds detected in drinking water from randomly selected community water systems in the study area, 1993-98

$[\mu \mathrm{g} / \mathrm{L}$, micrograms per liter]

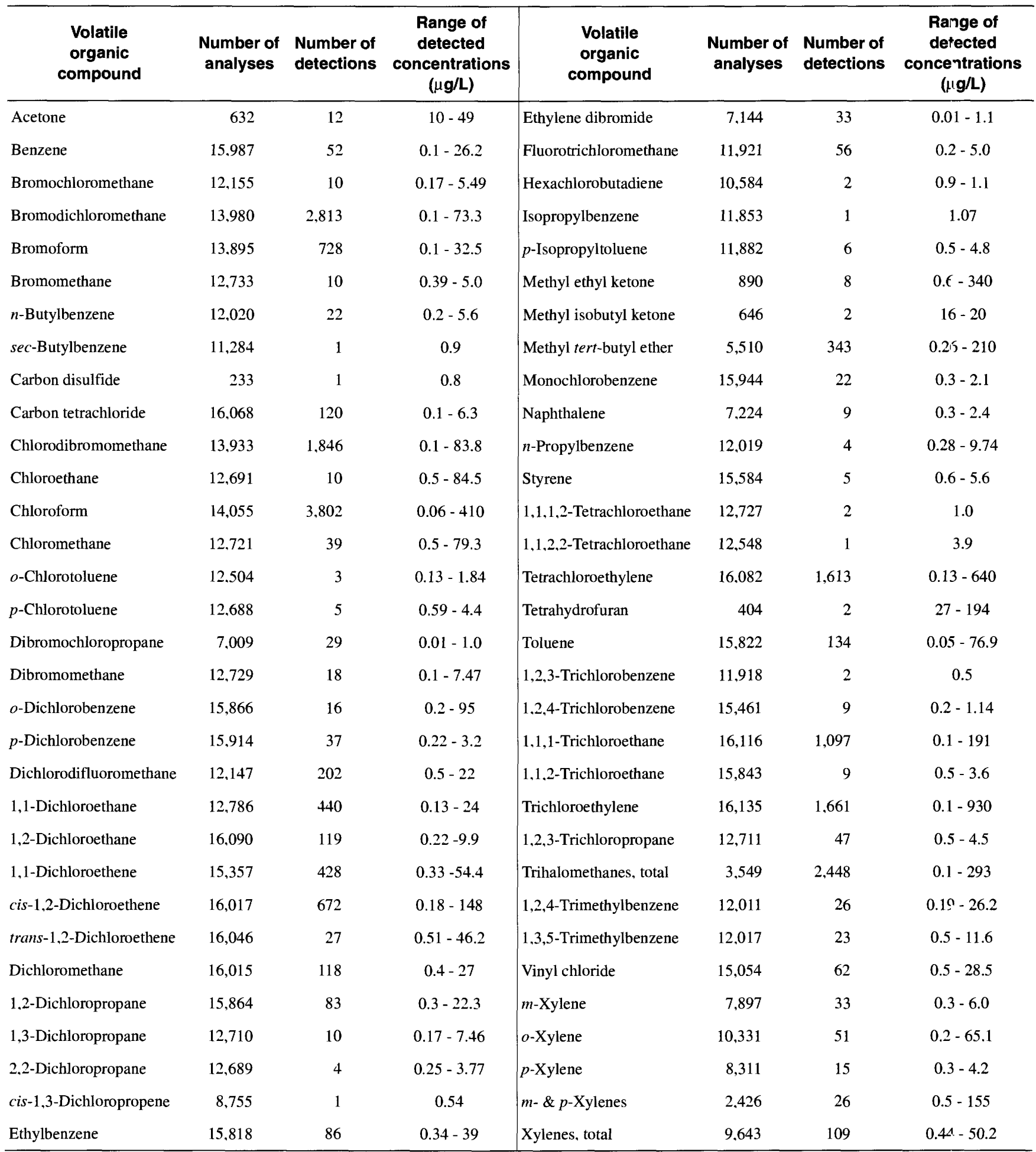


VOC concentrations in drinking-water samples reported by randomly selected CWSs in the 12-State area during 1993-98 ranged from $0.01 \mu \mathrm{g} / \mathrm{L}$ for detections of ethylene dibromide and dibromochloropropane to $930 \mu \mathrm{g} / \mathrm{L}$ for trichloroethylene (table 7). Most of the reported VOC concentrations are low (fig. 3) with 70 percent of all detections at concentrations less than 10 $\mu \mathrm{g} / \mathrm{L}$, but concentrations of 16 VOCs equaled or exceeded Federal drinking-water regulations or health advisories (table 8). Regulated or recommended levels for the 16 VOCs have been equaled or exceeded in 1,102 (5.1 percent) of the 21,635 drinking-water samples.

The 16 VOCs that have exceeded drinking-water regulations or recommendations include 8 solvents, 2 VOCs used mostly in the synthesis of organic compounds, 2 fumigants, 2 gasoline components (including MTBE), a refrigerant, and the sum of the four THM disinfectant by-products. One or more drinking-water samples exceeded the MCLs for 13 VOCs; 2 VOCs-chloromethane and hexachlorobutadiene-equaled or exceeded Health Advisory (HA) levels, and MTBE has been reported at concentrations equal to or exceeding the Drinking Water Advisory (DWA) level recommended based on aestheti : (taste and odor) considerations.

Although only a small percentage of all drinking-water samples equaled or exceeded MCLs, total trihalomethanes, trichloroethylene, and tetrachloroethylene have been reported at concentraticns that exceed MCLs in almost 200 to more than 500 samples collected during1993-98, and some of these samples contained concentrations more than 100 time: greater than the MCLs. Information coded with specific drinking-water samples indicates that some reported "MCL violations" by the affected CWSs were for unprocessed water samples collected from their sources prior to the distribution systems. It is also evident, at least for the CWSs with the high solvent concentrations, that the use of granular activated carbon filtration and other forms of water treatment or blending mitigate these concentrations prior to distributing the water, but the data indicate that several sources for these systems have been affected and the nature of some samples with high concentrations are poorly documented.

Table 8. Volatile organic compounds that equaled or exceeded regulated or recommended concentrations in drinking water from randomly selected community water systems in the study area, 1993-98

[ $\mu \mathrm{g} / \mathrm{L}$, micrograms per liter; MCL, Maximum Contaminant Level; HA, Health Advisory; DWA, Drinking-Water Advisory; CWSs, community water systems]

\begin{tabular}{|c|c|c|c|c|c|}
\hline \multirow{2}{*}{$\begin{array}{l}\text { Volatile organic } \\
\text { compound }\end{array}$} & \multicolumn{2}{|c|}{$\begin{array}{c}\text { Drinking-water regulation or } \\
\text { recommendation }\end{array}$} & \multirow{2}{*}{$\begin{array}{c}\text { Number of } \\
\text { samples with } \\
\text { concentrations } \\
\text { that equaled or } \\
\text { exceeded value }\end{array}$} & \multirow{2}{*}{$\begin{array}{l}\text { Number of CWSs } \\
\text { reporting } \\
\text { concentrations } \\
\text { that equaled or } \\
\text { exceeded value }\end{array}$} & \multirow{2}{*}{$\begin{array}{l}\text { Populaticn } \\
\text { served b" } \\
\text { affected Cl'Ss }\end{array}$} \\
\hline & Value, in $\mu g / L$ & Type & & & \\
\hline Benzene & 5 & MCL & 4 & 2 & 414 \\
\hline Carbon tetrachloride & 5 & MCL & 1 & 1 & 5,000 \\
\hline Dibromochloropropane & 0.2 & MCL & 3 & 3 & 39,269 \\
\hline 1,2-Dichloroethane & 5 & MCL & 3 & 2 & 1,655 \\
\hline 1,1-Dichloroethene & 7 & MCL & 89 & 6 & 105.592 \\
\hline cis-1,2-Dichloroethene & 70 & MCL & 2 & 2 & 29,425 \\
\hline Dichloromethane & 5 & MCL & 11 & 8 & 84,915 \\
\hline 1,2-Dichloropropane & 5 & MCL & 11 & 3 & 43,669 \\
\hline Ethylene dibromide & 0.05 & MCL & 8 & 5 & 539,168 \\
\hline Tetrachloroethylene & 5 & MCL & 515 & 32 & 840,448 \\
\hline Trichloroethylene & 5 & MCL & 496 & 25 & 497,750 \\
\hline Total trihalomethanes & 100 & MCL & 186 & 46 & 868,705 \\
\hline Vinyl chloride & 2 & MCL & 12 & 4 & 148,798 \\
\hline Chloromethane & 3 & HA & 14 & 11 & 50,029 \\
\hline Hexachlorobutadiene & 1 & HA & 1 & 1 & 425 \\
\hline Methyl tert-butyl ether & $20-40$ & DWA & 27 & 10 & 48,827 \\
\hline
\end{tabular}




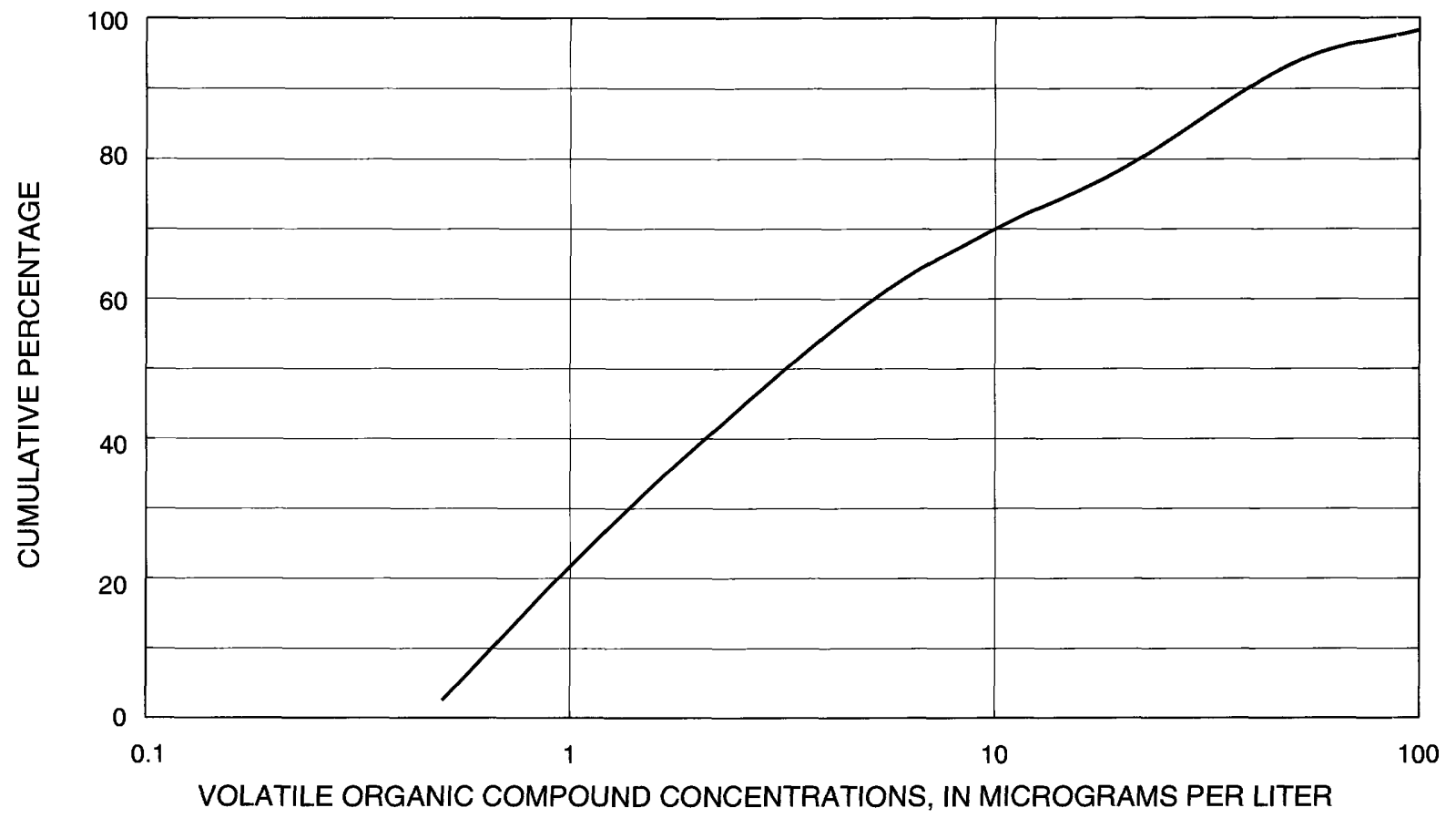

Figure 3. Cumulative distribution of concentrations of volatile organic compounds detected in drinking-water samples from randomly selected community water systems in the study area,1993-98 (data for 19,625 detections).

The frequency of detection for the 64 VOCs reported in drinking water ranged from 41 percent of CWSs with total trihalomethanes, to 0.01 percent of CWSs with isopropylbenzene (table 9). The four most frequently detected individual VOC analytes were the four THM compounds-chloroform, bromodichloromethane, chlorodibromomethane, and bromoform-chemicals produced as by-products of disinfecting drinking water with chlorine. This observation is consistent with the fact that nearly all the drinking-water data are purported to represent "finished" drinking water, collected at the point-ofentry to the CWS's distribution system (or at more distal locations within the distribution system) following whatever water-treatment processes, such as chlorination, the CWSs may utilize.

MTBE was the next most frequently detected VOC, reported in 8.9 percent of the 1,194 CWSs where it was tested for, and, after the trihalomethanes, was the only VOC other than the solvent 1,1,1-trichloroethane to be detected in more than 5 percent of the CWSs. Two other common solvents, tetrachloroethylene and trichloroethylene, and two gasoline compounds, toluene and total xylenes, were detected in drinking water from more than 4 percent of the CWSs. About one-third of the VOCs detected in drinking water were reported in 1 to 3 percent of the CWSs, but more than half (33) of the 64 VOCs detected in drinking, water were found in less than 1 percent of CWSs sampled for these compounds. The infrequent detections of many VOCs at generally low concentrations, togetl ar with the lack of any detections for 20 other VOC analytes (table 10) underscores the observation that al hough some VOCs, including MTBE, have been reported widely in drinking water in the Northeast anc' MidAtlantic region, the problem is largely confin $2 \mathrm{~d}$ to fewer than a dozen contaminants.

Analytical coverage for VOCs in drinking water among the randomly selected CWSs was highly variable (see tables 7, 9, appendix 2) and none of the 84 VOCs were tested for by all $2,110 \mathrm{CWSs}$, and $20 \mathrm{VOCs}$ were analyzed by less than half of the CWSs. The most frequent VOC analytes were 19 of the regulated VOCs that were tested for at least once by 97 percent of the CWSs. An additional 17 of the VOCs were tested for by 75 percent or more of the CWSs, and 24 other VOC analytes were analyzed for by more than 50 percent of the 2,110 CWSs. Among VOCs that have been 
detected in drinking water, 9 were analyzed for in less than half of the 2,110 CWSs (with as few as 103 CWSs reporting analyses for carbon disulfide).

The THM data demonstrate how the problem of missing data for a substantial number of CWSs confounds comparison of the detection frequencies for some VOCs. Although THMs were among the most frequently analyzed VOCs, almost 27 percent of the randomly selected CWSs reported no THM data, including 32 percent (174 of 538) of the CWSs in New York and 88 percent ( 388 of 443 ) of the systems in Pennsylvania. Furthermore, the majority of the CWSs without THM data are small to medium sized, groundwater supplied systems that are less likely to chlorinate their water, may have lower levels of naturally occurring organic compounds, and consequently, would have lower THM detection frequencies than larger surface-water supplied systems. The incomplete THM data and the resulting nonrepresentative distribution of systems reporting THM results introduces a bias into the calculated THM detection frequency.

Other differences in the data, including different reporting levels used by various State and private laboratories and disparate numbers of samples reported for each CWS, also may confound a State-by-State (or by source, size, or other system characteristics) comparison of VOC-detection frequencies. The lack of a consistent analytical coverage and reporting levels hampers comparisons of detection frequencies and diminishes the representativeness of the findings. Little can be done to standardize the data for large numbers of missing analyses, but reporting levels can be made more uniform by censoring the data at relevant concentrations. This approach has been used when possible in the following sections to facilitate comparisons of detection frequencies of specific analytes by source, size, and State.

By censoring the data at the $1.0-\mu \mathrm{g} / \mathrm{L}$ reporting level and including only those analytes with data for at least half $(1,055)$ of the 2,110 randomly selected CWSs, a more meaningful comparison can be made of the relative occurrence of $54 \mathrm{VOC}$ contaminants that meet these criteria. Among the 64 VOCs reported in drinking water (see tables 7 and 9), only 8-acetone, sec-butylbenzene, carbon disulfide, cis-1,3-dichloropropene, methyl ethyl ketone, methyl isobutyl ketone, tetrahydrofuran, and 1,2,3-trichlorobenzene-are dropped from any further analysis of VOC detection frequencies because they do not meet one or both these criteria. Also, five other VOC analytes included in tables 7 and 9 that have been reported inconsistently in the State databases-total trihalomethanes, xylenes total, $m$-xylene, $p$-xylene, and $m$ - \& $p$-xylenes-are replaced by the calculated sums for "total trihalomethanes" (sum of the concentrations of the chlc "oform, bromodichloromethane, chlorodibromomethane, bromoform or the value of total trihalomethanes coded in some analyses), " $m$ - $\& p$-xylenes" (sum of $m$-xylene and $p$-xylene or the value of $m$ - $\& p$-xylenes coded in some analyses), and "total xylenes" (sum of the calculated $m$ - \& $p$-xylenes plus $o$-xylene values or the value of total xylenes coded in some analyses) in the following analysis. Although most VOC analytes were reported by the States at the $0.5-\mu \mathrm{g} / \mathrm{L}$ reporting level, using the $1.0-\mu \mathrm{g} / \mathrm{L}$ reporting level allows combarison of detection frequencies at a conservative quantification level (above the practical quantification limit for all analytes) and allows for inclusion of MTBE in the comparison. At a reporting level of $0.5 \mu \mathrm{g} / \mathrm{L}$, only 985 CWSs had analytical data for MTBE. The requirement of having data for at least half of the 2,110 CWSs allows for a minimum of 10 percent of all CWSs in the 12-State area to be represented in the data.

The frequency of detection at a reporting level of $1.0 \mu \mathrm{g} / \mathrm{L}$ for the $54 \mathrm{VOC}$ analytes (or sums of a nalytes) that were sampled for in drinking water from at least half of the 2,110 randomly selected CWSs in the study area are listed in appendix 3 and are shown in figure 4. This figure demonstrates the pervasiveness of the trihalomethane disinfectant by-products in drinking water compared to all other types of VOCs. Trihalomethane detection frequencies at $1.0 \mu \mathrm{g} / \mathrm{L}$ range from 8 percent (bromoform) to almost 34 percent (chloroform) of the randomly selected CWSs, and were generally f"om 2 to more than 300 times other VOCs. MTBE, reported in 7.8 percent of the CWSs, was the only other VOC detected in more than 5 percent of the CWSs at a reporting level of $1.0 \mu \mathrm{g} / \mathrm{L}$. MTBE plus five additional gasoline components were among the most common VOCs reported in drinking water, however co'lectively, solvent compounds were the most numarous VOCs detected in drinking water. Nearly half (23) of the 54 VOCs detected in drinking water at a reporting level of $1.0 \mu \mathrm{g} / \mathrm{L}$ were solvents, including the widely used compounds tetrachloroethylene, trichloroethylene, and 1,1,1-trichloroethane. VOCs with more limited uses-organic synthesis compounds, refrigerants, and fumigants-were generally detected in less than 1 percent of the CWSs at concentrations at or above $1.0 \mu \mathrm{g} / \mathrm{L}$. 
Table 9. Frequency of detection of volatile organic compounds at any reporting level in drinking water from randomly selected community water systems in the study area, 1993-98

[CWSs, community water systems]

\begin{tabular}{|c|c|c|c|c|c|c|c|}
\hline $\begin{array}{c}\text { Volatile } \\
\text { organic } \\
\text { compound }\end{array}$ & $\begin{array}{c}\text { Number of } \\
\text { CWSs with } \\
\text { analyses }\end{array}$ & $\begin{array}{l}\text { Number of } \\
\text { CWSs with } \\
\text { detections }\end{array}$ & $\begin{array}{c}\text { Percentage } \\
\text { of CWSs } \\
\text { with } \\
\text { detections }\end{array}$ & $\begin{array}{c}\text { Volatile } \\
\text { organic } \\
\text { compound }\end{array}$ & $\begin{array}{l}\text { Number of } \\
\text { CWSs with } \\
\text { analyses }\end{array}$ & $\begin{array}{l}\text { Number of } \\
\text { CWSs with } \\
\text { detections }\end{array}$ & $\begin{array}{c}\text { F vrcentage } \\
\text { of CWSs } \\
\text { with } \\
\text { crotections }\end{array}$ \\
\hline \multicolumn{4}{|c|}{ Disinfectant by-products } & trans-1,2-Dichloroethene & 2.090 & 13 & 0.6 \\
\hline Trihalomethanes, total & 304 & 125 & 41 & Chloroethane & 1,665 & 7 & 0.4 \\
\hline Chloroform & 1.504 & 589 & 39 & $o$-Dichlorobenzene & 2,096 & 8 & 0.4 \\
\hline Bromodichloromethane & 1.503 & 486 & 32 & Methyl isobutyl ketone & 331 & 2 & 0.3 \\
\hline Chlorodibromomethane & 1,507 & 389 & 26 & $1,2,4$-Trichlorobenzene & 2,092 & 7 & 0.3 \\
\hline Bromoform & 1,504 & 193 & 13 & 1,1,2-Trichloroethane & 2,088 & 6 & 0.3 \\
\hline \multicolumn{4}{|c|}{ Gasoline components } & Monochlorobenzene & 2,096 & 5 & 0.2 \\
\hline Methyl tert-butyl ether & 1,194 & 106 & 8.9 & n-Propylbenzene & 1,569 & 4 & 0.2 \\
\hline Xylenes, total & 1.339 & 57 & 4.3 & $p$-Chlorotoluene & 1,672 & 4 & 0.2 \\
\hline Toluene & 2,095 & 88 & 4.2 & 1,2,3-Trichloropropane & 1,665 & 4 & 0.2 \\
\hline$m$-Xylene & 600 & 17 & 2.8 & $o$-Chlorotoluene & 1,584 & 2 & 0.1 \\
\hline Ethylbenzene & 2,095 & 51 & 2.4 & 1,1,1,2-Tetrachloroethane & 1,667 & 2 & 0.1 \\
\hline$o$-Xylene & 1.423 & 32 & 2.2 & 1,1,2.2-Tetrachloroethane & 1,581 & 1 & 0.06 \\
\hline$m$ - \& $p$-Xylenes & 876 & 16 & 1.8 & \multicolumn{4}{|c|}{ Fumigants } \\
\hline$p$-Xylene & 683 & 11 & 1.6 & Dibromochloropropane & 1,440 & 25 & 1.7 \\
\hline Benzene & 2,095 & 30 & 1.4 & Ethylene dibromide & 1.517 & 26 & 1.7 \\
\hline Naphthalene & 1,379 & 8 & 0.6 & $p$-Dichlorobenzene & 2,096 & 19 & 0.9 \\
\hline$n$-Butylbenzene & 1.569 & 6 & 0.4 & Bromomethane & 1,667 & 9 & 0.5 \\
\hline 1,3,5-Trimethylbenzene & 1,568 & 7 & 0.4 & cis-1,3-Dichloropropene & 1,078 & 1 & 0.09 \\
\hline sec-Butylbenzene & 1,471 & 1 & 0.07 & & Refrigerant & & \\
\hline \multicolumn{4}{|c|}{ Solvents } & Chloromethane & 1,667 & 29 & 1.7 \\
\hline 1,1.1-Trichloroethane & 2.086 & 106 & 5.1 & Dichlorodifluoromethane & 1,628 & 20 & 1.2 \\
\hline Trichloroethylene & 2.090 & 94 & 4.5 & Fluorotrichloromethane & 1,543 & 9 & 0.6 \\
\hline Tetrachloroethylene & 2.090 & 93 & 4.4 & \multicolumn{4}{|c|}{ Organic synthesis compounds } \\
\hline Dichloromethane & 2,088 & 60 & 2.9 & Carbon disulfide & 103 & 1 & 1.0 \\
\hline Acetone & 309 & 9 & 2.9 & Bromochloromethane & 1,628 & 10 & 0.6 \\
\hline cis-1,2-Dichloroethene & 2,089 & 43 & 2.1 & 1,2.4-Trimethylbenzene & 1,567 & 9 & 0.6 \\
\hline 1,1-Dichloroethane & 1,666 & 31 & 1.9 & Vinyl chloride & 2,062 & 9 & 0.4 \\
\hline 1,2-Dichloroethane & 2,088 & 39 & 1.9 & 1,3-Dichloropropane & 1,665 & 5 & 0.3 \\
\hline 1,1-Dichloroethene & 1,785 & 34 & 1.9 & 2,2-Dichloropropane & 1,666 & 3 & 0.2 \\
\hline Methyl ethyl ketone & 334 & 6 & 1.8 & Hexachlorobutadiene & 1,167 & 2 & 0.2 \\
\hline Carbon tetrachloride & 2,086 & 32 & 1.5 & Styrene & 2.078 & 5 & 0.2 \\
\hline Tetrahydrofuran & 136 & 2 & 1.5 & $p$-Isopropyltoluene & 1.548 & 2 & 0.1 \\
\hline Dibromomethane & 1,667 & 14 & 0.8 & 1,2.3-Trichlorobenzene & 1,550 & 1 & 0.06 \\
\hline 1,2-Dichloropropane & 2,087 & 15 & 0.7 & Isopropylbenzene & 1,546 & 1 & 0.01 \\
\hline
\end{tabular}


Table 10. Volatile organic compounds undetected in drinking water from randomly selected community water systems in the study area, 1993-98

[CWSs, community water systems]

\begin{tabular}{lrr|lrc}
\hline \multicolumn{1}{c}{ Volatile organic compound } & $\begin{array}{c}\text { Number of } \\
\text { analyses }\end{array}$ & $\begin{array}{c}\text { Number of } \\
\text { CWSs with } \\
\text { analyses }\end{array}$ & Volatile organic compound & $\begin{array}{r}\text { Number of } \\
\text { analyses }\end{array}$ & $\begin{array}{c}\text { N'Imber of } \\
\text { C'NSs with } \\
\text { snalyses }\end{array}$ \\
\hline Acrolein & 32 & 8 & cis- \& trans-1,3-Dichloropropene & 3,498 & 463 \\
Acrylonitrile & 32 & 8 & Diethyl ether & 411 & 134 \\
Bromobenzene & 11,966 & 1,368 & Hexachloroethane & 24 & 4 \\
tert-Butylbenzene & 11,283 & 1,470 & $n$-Hexane & 83 & 13 \\
1-Chlorobutane & 24 & 4 & Methyl butyl ketone & 233 & 103 \\
2-Chloroethyl vinyl ether & 59 & 8 & Methyl methacrylate & 24 & 4 \\
$m$-Dichlorobenzene & 12,736 & 1,674 & Nitrobenzene & 24 & 4 \\
Dichlorobenzenes, mixed isomers & 124 & 27 & Pentachloroethane & 24 & 4 \\
1,1-Dichloropropene & 12,713 & 1,665 & $1,1,2$-Trichloro-1,2,2-trifluoroethane & 172 & 80 \\
trans-1,3-Dichloropropene & 8,757 & 1,078 & $1,2,3$-Trimethylbenzene & 389 & 101 \\
\hline
\end{tabular}

Overall, VOCs were detected at or above $1.0 \mu \mathrm{g} / \mathrm{L}$ in drinking-water samples from 38 percent (795) of the 2,110 randomly selected CWSs (table 11), however, detections were reported nearly three times more frequently in drinking water from systems supplied by surface-water sources $(75$ percent of 270 CWSs) or both surface- and ground-water sources (74 percent of $150 \mathrm{CWSs}$ ) than in systems supplied exclusively by ground-water sources ( 28 percent of 1,690 CWSs). The occurrence of VOCs also was clearly related to the size of CWSs-very large and large systems reported more frequent detections at or above $1.0 \mu \mathrm{g} / \mathrm{L}$ (100 percent and 79 percent, respectively) than medium and small systems (50 percent and 24 percent, respectively). The observation that, in general, VOCs are detected more frequently in large to very large CWSs supplied at least in part by surface-water sources, than in smaller systems supplied exclusively by ground-water sources clearly reflects the elevated occurrence of THMs in those systems (table 12), but other VOCs also were detected most often in drinking water from the larger CWSs.

The frequency of VOC detections at or above $1.0 \mu \mathrm{g} / \mathrm{L}$ in drinking water ranged considerably from State to State (table 11), with the highest frequencies $(68,60$, and 59 percent of CWSs for New Jerse`, Rhode Island, and Massachusetts, respectively) reported by States with high population density (table 13) and extensive urban development. Still, more than 30 percent of the CWSs in 10 States have reported concentrations of the 54 selected VOCs at or above $1.0 \mu \mathrm{g} / \mathrm{L}$ in drinking water, and more than 20 percent of the systems in all 12 States have had these VOCs in their drinking water at comparable concentrations (table 11). The lowest VOC-detection frequencies were in large States with substantial rural regions (Maine and Pennsylvania). This may reflect a relative paucity of sources of VOC contaminants in rural areas, but it also may be an artifact of the somewhat more limited suite of VOC analytes tested for in many drinking-water samples from these States (see table 5 and appendix 2). 

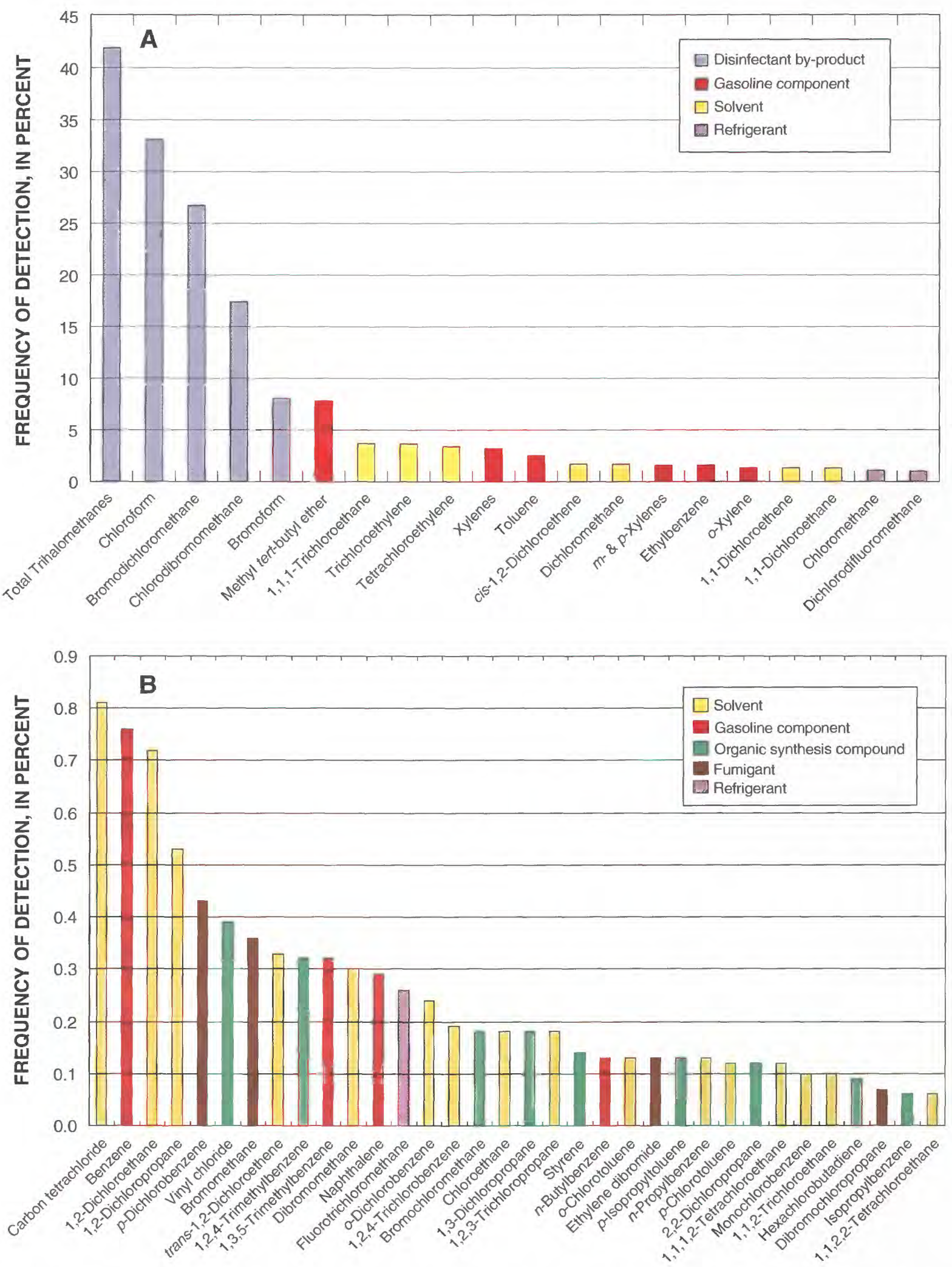

Figure 4. Frequency of detection of volatile organic compounds at concentrations equal to or exceeding 1.0 microgram per liter in drinking water from randomly selected community water systems in the study area for (A) 20 volatile organic compounds with detection frequencies greater than 1 percent, and (B) 34 volatile organic compounds with detection frequencies less than 1 percent. (Number of community water systems with analyses varies by compound; see appendix 3 .) 
Table 11. Randomly selected community water systems in the study area reporting concentrations at or above 1.0 microgram per liter for 54 selected volatile organic compounds in drinking water by State, source of water, and population served, 1993-98

[Both includes community water systems (CWS) supplied by ground-water and surface-water sources; -, no CWSs in this category]

\begin{tabular}{|c|c|c|c|c|c|c|c|c|c|}
\hline \multirow[b]{3}{*}{ State } & \multicolumn{8}{|c|}{$\begin{array}{l}\text { Number of randomly selected CWSs reporting concentrations of selected } \\
\text { volatile organic compounds at or above } 1.0 \text { microgram per liter }\end{array}$} & \multirow[b]{3}{*}{$\begin{array}{l}\text { Percentage of } \\
\text { CWSs }\end{array}$} \\
\hline & \multicolumn{3}{|c|}{ Principal source of water } & \multicolumn{4}{|c|}{ Population served } & \multirow[b]{2}{*}{ Total } & \\
\hline & $\begin{array}{l}\text { Ground } \\
\text { water }\end{array}$ & $\begin{array}{l}\text { Surface } \\
\text { water }\end{array}$ & Both & $\begin{array}{c}\text { More } \\
\text { than } \\
50,000\end{array}$ & $\begin{array}{c}3,301 \\
\text { to } \\
50,000\end{array}$ & $\begin{array}{c}501 \\
\text { to } \\
3,300\end{array}$ & $\begin{array}{c}25 \\
\text { to } \\
500\end{array}$ & & \\
\hline Conn. & 33 & 1 & 8 & 2 & 8 & 7 & 25 & 42 & 35 \\
\hline Del. & 13 & 1 & - & 1 & 0 & 3 & 10 & 14 & 30 \\
\hline Maine & 17 & 3 & 0 & - & 2 & 4 & 14 & 20 & 25 \\
\hline Md. & 28 & 6 & 5 & 1 & 6 & 10 & 22 & 39 & 39 \\
\hline Mass. & 33 & 9 & 20 & 5 & 38 & 6 & 13 & 62 & 59 \\
\hline N.H. & 34 & 9 & 6 & - & 6 & 15 & 28 & 49 & 37 \\
\hline N.J. & 66 & 10 & 7 & 4 & 36 & 18 & 25 & 83 & 68 \\
\hline N.Y. & 123 & 83 & 31 & 6 & 53 & 80 & 98 & 237 & 44 \\
\hline Pa. & 52 & 31 & 15 & 6 & 38 & 24 & 30 & 98 & 22 \\
\hline R.I. & 12 & 2 & 4 & 2 & 6 & 2 & 8 & 18 & 60 \\
\hline Vt. & 20 & 7 & 6 & - & 3 & 10 & 20 & 33 & 38 \\
\hline Va. & 50 & 41 & 9 & 4 & 19 & 30 & 47 & 100 & 33 \\
\hline $\begin{array}{l}\text { Total } \\
\text { (percent) }\end{array}$ & $\begin{array}{l}481 \\
(28)\end{array}$ & $\begin{array}{l}203 \\
(75)\end{array}$ & $\begin{array}{l}111 \\
(74)\end{array}$ & $\begin{array}{r}31 \\
(100)\end{array}$ & $\begin{array}{l}215 \\
(79)\end{array}$ & $\begin{array}{l}209 \\
(50)\end{array}$ & $\begin{array}{l}340 \\
(24)\end{array}$ & $\begin{array}{l}795 \\
(38)\end{array}$ & 38 \\
\hline
\end{tabular}

Table 12. Comparison of the frequency of detection of volatile organic compounds at concentrations at or above 1.0 microgram per liter in drinking water from randomly selected community water systems in the study area by source of water and size, 1993-98

$[\mu \mathrm{g} / \mathrm{L}$, micrograms per liter; MTBE, methyl tert-butyl ether. Both includes water systems that have ground-water and surface-water sources; very large $=$ more than 50,000 people served; large $=3,301$ to 50,000 people served; medium $=501$ to 3,300 people served: small $=25$ to 500 people served]

\begin{tabular}{|c|c|c|c|c|}
\hline \multirow[b]{2}{*}{ Source - size category } & \multicolumn{4}{|c|}{ Frequency of detection at or above $1.0 \mu \mathrm{g} / \mathrm{L}$} \\
\hline & $\begin{array}{c}\text { Any volatile } \\
\text { organic } \\
\text { compound }\end{array}$ & Trihalomethanes $^{1}$ & $\begin{array}{l}\text { Non-trihalom- } \\
\text { ethanes }\end{array}$ & MTBE \\
\hline Ground water - very large & 100 & 100 & 100 & 50 \\
\hline Ground water- large & 73 & 57 & 56 & 13 \\
\hline Ground water - medium & 40 & 36 & 23 & 6.3 \\
\hline Ground water - small & 22 & 20 & 12 & 7.3 \\
\hline Surface water - very large & 100 & 100 & 31 & 0 \\
\hline Surface water - large & 84 & 90 & 18 & 2.2 \\
\hline Surface water - medium & 68 & 88 & 10 & 5.7 \\
\hline Surface water - small & 67 & 86 & 10 & 0 \\
\hline Both - very large & 100 & 100 & 82 & 75 \\
\hline Both - large & 83 & 90 & 29 & 16 \\
\hline Both - medium & 64 & 85 & 27 & 0 \\
\hline Both - small & 57 & 73 & 19 & 8.3 \\
\hline
\end{tabular}

${ }^{1}$ Not adjusted for missing data. 
Table 13. Comparison between average population density and the frequency of detection of volatile organic compounds at concentrations at or above 1.0 microgram per liter in drinking water in the study area, 1993-98

[Population density is statewide average for 1995 from Grady and Casey, 1999. table 2]

\begin{tabular}{lccc}
\hline \multicolumn{1}{c}{ State } & $\begin{array}{c}\text { Population } \\
\text { density } \\
\text { (people per } \\
\text { square mile) }\end{array}$ & $\begin{array}{c}\text { Rank of detection } \\
\text { frequency } \\
\text { for any volatile } \\
\text { organic compound }\end{array}$ & $\begin{array}{c}\text { Rank of detection } \\
\text { frequency for } \\
\text { non-trihalomethane } \\
\text { volatile organic } \\
\text { compounds }\end{array}$ \\
\hline New Jersey & 911 & 1 & 2.5 \\
Rhode Island & 641 & 2 & 1 \\
Connecticut & 591 & 8 & 4 \\
Massachusetts & 575 & 3 & 2.5 \\
Maryland & 406 & 5 & 7 \\
New York & 333 & 4 & 10 \\
Delaware & 288 & 10 & 8 \\
Pennsylvania & 262 & 12 & 9 \\
Virginia ${ }^{1}$ & 167 & 9 & 5 \\
New Hampshire & 123 & 7 & 11 \\
Vermont & 61 & 6 & 6 \\
Maine & 35 & 11 & \\
\hline \multicolumn{1}{l}{${ }^{\text {Includes District of Columbia }}$} & & & 5 \\
\hline
\end{tabular}

A statistical analysis was performed to determine if the frequency of detection of VOCs in drinking water at concentrations equal to or exceeding $1.0 \mu \mathrm{g} / \mathrm{L}$ was related to urban land use. For this analysis, those areas with population density equal to or greater than 1,000 people per $\mathrm{mi}^{2}$ were considered urban. Locations of drinking-water sources were compared to digital data on 1990 population density with a $1-\mathrm{km}^{2}$-resolution (Price and Clawges, 1999) for the 12-State area. CWSs were classified as urban if one or more of their sources were in areas with population density of 1,000 people per $\mathrm{mi}^{2}$ ( 386 people per $\mathrm{km}^{2}$ ) or more. A total of 263 of the 2,110 randomly selected CWSs were determined to have one or more source in an urban area. The remaining 1,847 CWSs had no known sources in areas with population density equal to or greater than 1,000 people per $\mathrm{mi}^{2}$ and were classified as rural. It is also important to note that no information was available to allow any systematic interpretation of which aquifer system was tapped by the ground-water sources, what the direction of ground-water flow may have been, or the extent of the area contributing flow to the well. It is very likely that some ground-water sources tapped confined aquifers that are isolated from the overlying land use, that the direction of groundwater flow may not be from urban areas adjacent to wells, or that the contributing areas for wells tapping surficial aquifers may be much smaller than the $1-\mathrm{km}^{2}$ resolution land-use categories.

The frequency of detecting any VOCs at any reporting level was more likely in urban areas than in rural areas (fig. 5); 67 percent of the urban CWSs verses 42 percent of the rural CWSs had detections. At a reporting level of $1.0 \mu \mathrm{g} / \mathrm{L}$, the VOC detection frequency was 1.8 times greater in CWSs with sources in high-population density, urban areas than in CWSs with sources only in rural areas (table 14). A 2-by-2 contingency-table test rejected the null hypothesis that detection frequency was independent of population density at a very high level of significance $(p<0.0001)$. A similar analysis was performed using the frequency of detection of non-trihalomethane (non-THM) VOCs (fig. 6) to evaluate the effects of population density on VOC occurrence without masking the relation with the widespread presence of disinfectant by-products. The frequency of detecting non-THM VOCs at concentrations equal to or exceeding $1.0 \mu \mathrm{g} / \mathrm{L}$ in drinking water from CWSs with urban sources was 2.5 times that of CWSs with only rural sources, and the attained significance level was similarly high $(\mathrm{p}<0.0001)$. The relation of urban land use to non-THM VOC occurrence also was largely independent of reporting level. 


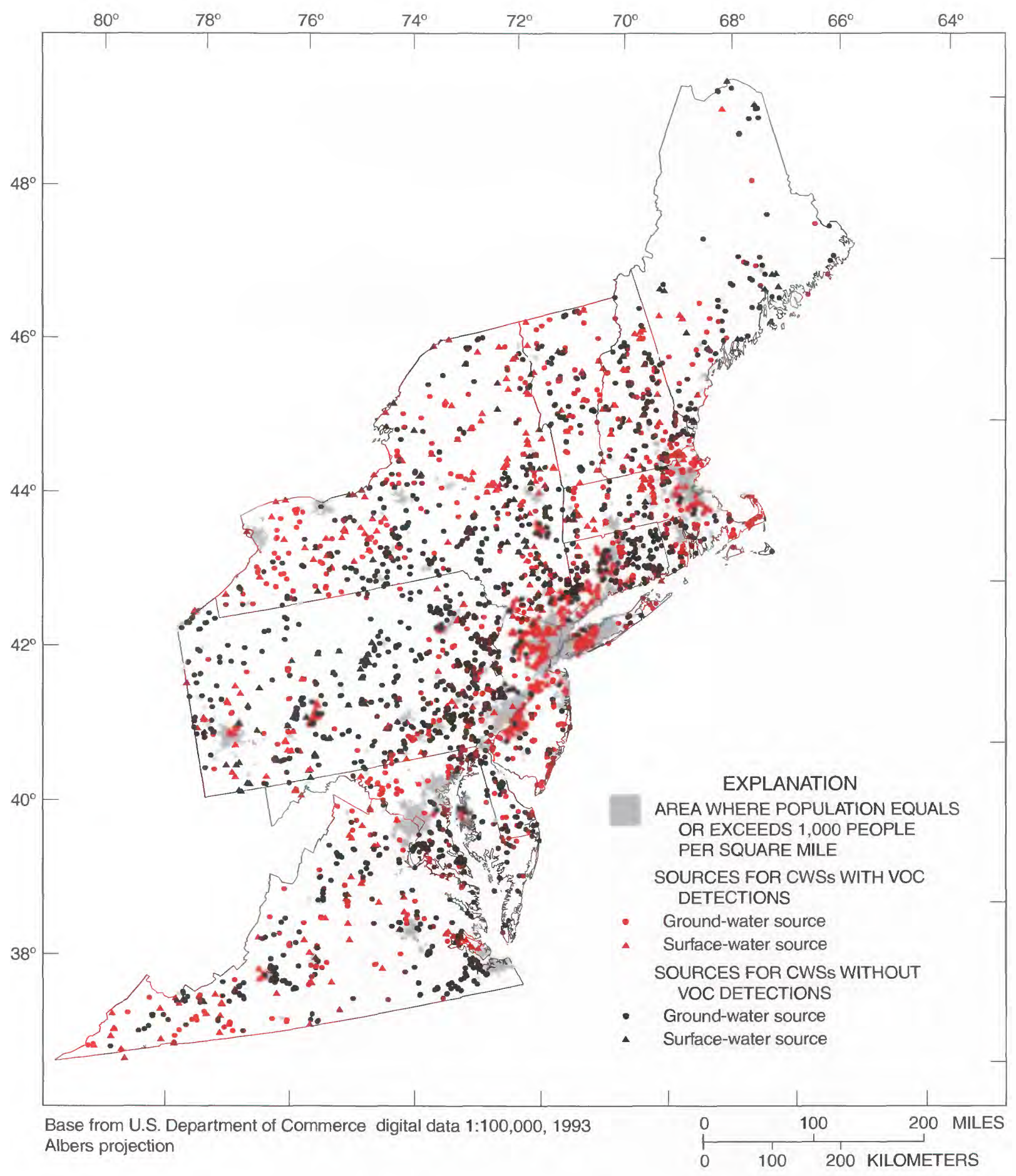

Figure 5. Drinking-water sources for randomly selected community water systems in the study area, showing systems with analytical data and systems with reported detectable concentrations of any volatile organic compound, in relation to urban land use. 


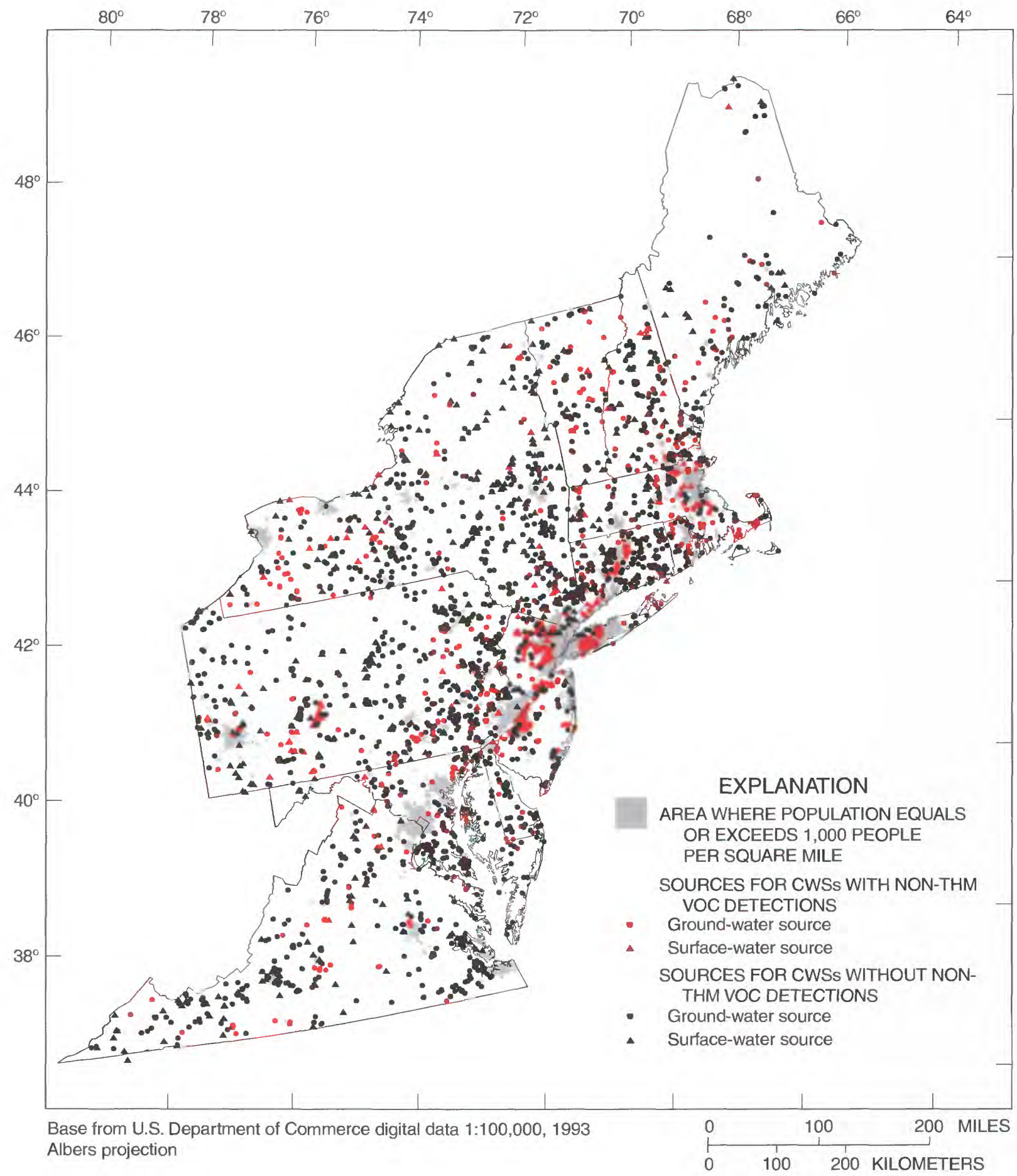

Figure 6. Drinking-water sources for randomly selected community water systems in the study area, showing systems with analytical data and systems with reported detectable concentrations of any non-trihalomethane volatile organic compound, in relation to land use. 
Table 14. Relations between the occurrence of volatile organic compounds at or above 1.0 microgram per liter and at concentrations that equal or exceed a drinking-water regulation or recommendation in drinking water from randomly selected community water systems in the study area and source of water, size of system, and land use at sources

[CWSs, community water systems; THM, trihalomethane; VOC, volatile organic compound; MTBE, methyl tert-butyl ether: factors with statistical populations that share the same letter symbol are not significantly different at $\alpha=0.05$ based on contingency-table tests; >, greater than]

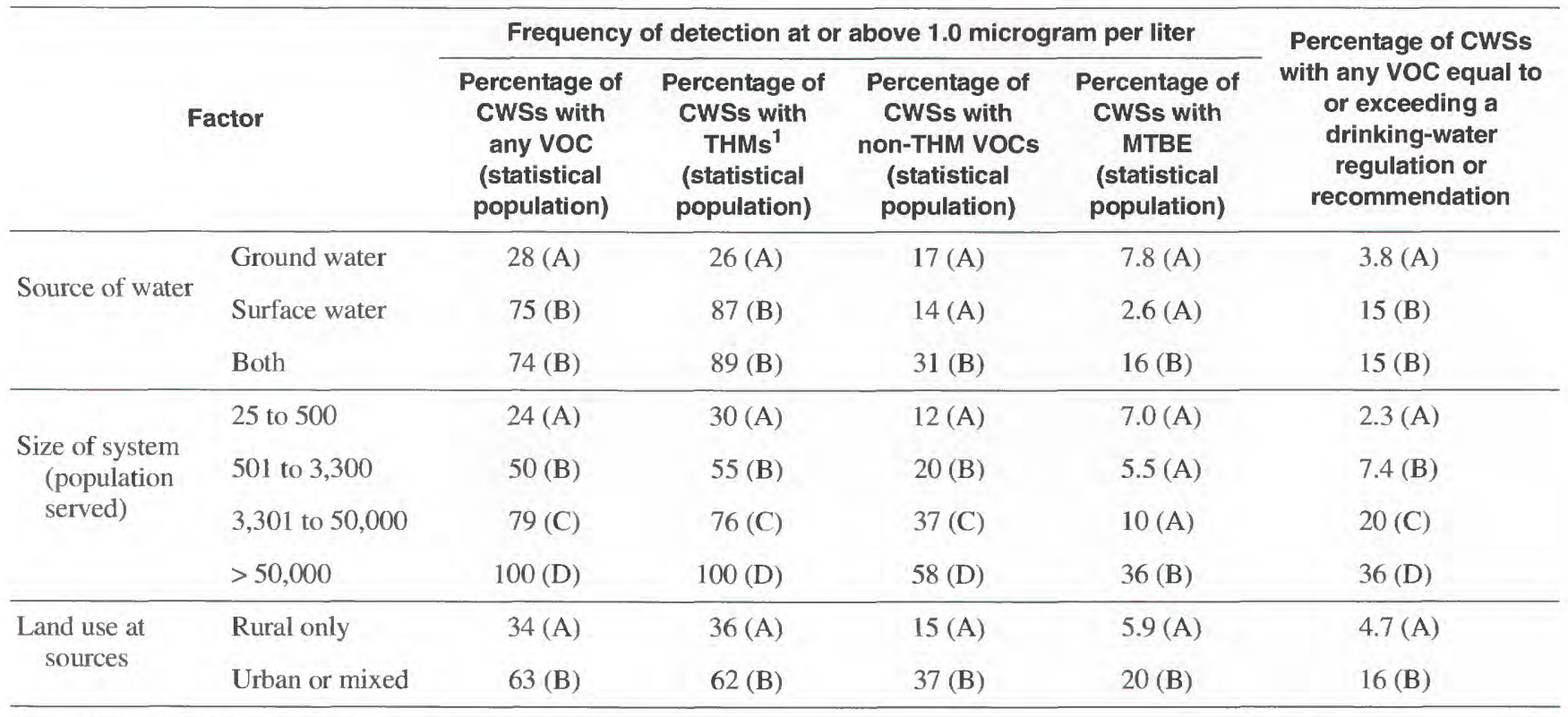

${ }^{1}$ Not adjusted for missing data.

As with the occurrence of most of these compounds, the distribution of CWSs that have reported VOCs at or above drinking-water regulations or recommendations is significantly related to urban areas with high population density. A contingencytable test for the hypothesis that exceedance of drinking-water regulations or recommendations is independent of population density was rejected at $\mathrm{p}<0.0001$. Fifteen percent of the CWSs that reported concentrations of one or more VOC that equaled or exceeded a drinking-water regulation or recommendation had sources in urban areas compared to about 5 percent of the CWSs that only have sources in rural areas. Also, the propensity for the exceedances to occur for systems that serve large populations from multiple ground- and surface-water sources, which are more prevalent in urban areas, was observed (table 14).

An additional element of concern about the occurrence of VOCs in drinking water is the extent to which VOCs co-occur in water samples. Recent evidence indicates that exposure to even low levels of some contaminants may be linked to adverse biological effects including chemical sensitivity, endocrine disruption, and cancer (Ashford and Miller, 1998). Concern has been raised about the possible synergistic effects of co-occurring multiple contaminants in drinking water. The review of data on VOCs in drinking water in the 12-State area indicates that two or more compounds co-occur in more than half of the samples with VOC detections. Although most of the time the number of VOCs reported in any sample is three or fewer compounds, 12 percent of the samples with VOC detections contained four or five compounds, and about 3 percent contained five or more VOCs (fig. 7).

A tabulation of the percent co-occurrence for the 64 VOCs detected at any concentration in drinking water in the study area is shown in appendix 4 . The appendix lists 184 pairs of VOCs with co-occurrence of 20 percent or more; 82 paired VOCs exhibit co-occurrence of 50 percent or more. Co-occurrence may occur when several VOCs have a common source, for example, the presence of the several trihalomethanes in a drinking-water sample may likely be related to disinfection. By contrast, the co-occurrence of multiple VOCs, often including MTBE, chloroform and (or) other trihalomethanes, and several common solvents, does not necessarily imply a common source for these contaminants, but rather may be an artifact of their overlapping, widespread occurrence. 


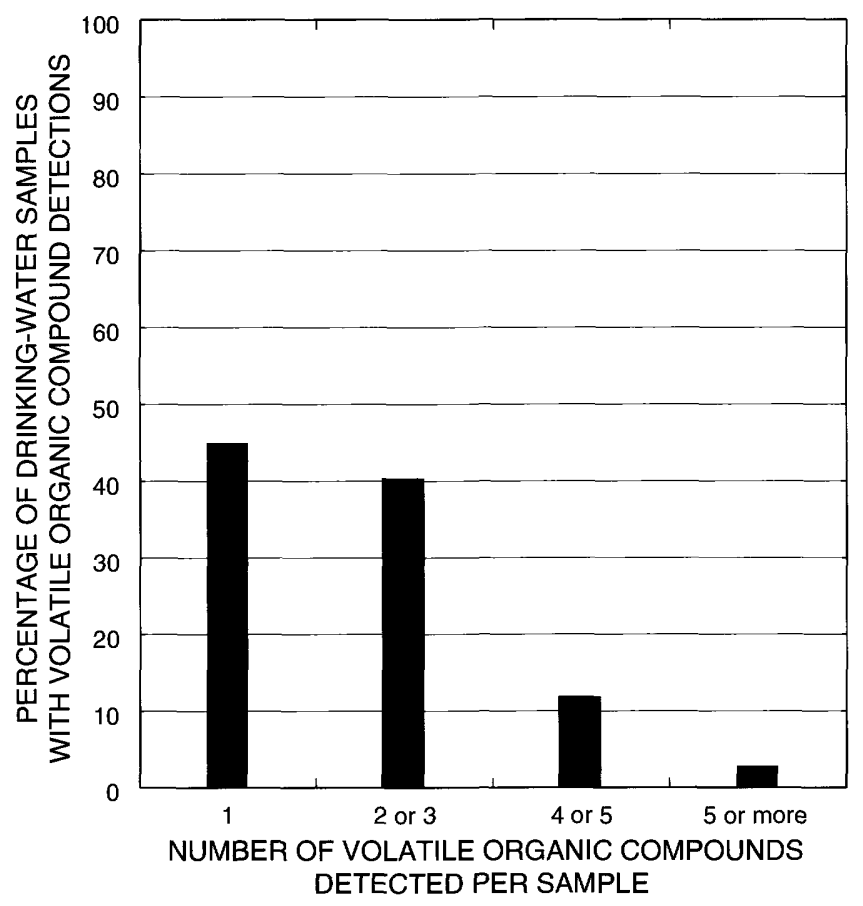

Figure 7. Frequency of co-occurrence of volatile organic compounds in drinking-water samples from randomly selected community water systems in the study area.
A more detailed discussion of the occurrence, co-occurrence, and distribution of the various types of VOCs in drinking water in the 12-State area follows. VOCs that may be related with regard to their principal use and (or) potential sources have been grouped for this discussion. Relations between VOC occurrence and distribution and some anthropogenic factors are evaluated and estimates of the number of people exposed to VOCs in their drinking water are presented.

\section{Disinfectant By-Products}

Disinfection of drinking water is necessary to prevent disease caused by waterborne pathogens in public drinking water; however, the disinfectants can react with naturally occurring materials (humic acids) in source water and distribution systems to form unintended by-products (Pomes and others, 1999). Four
THM compounds-chloroform, bromodichloromethane. chlorodibromomethane, bromoform-are among the by-products often generated by the most commonly used process (chlorination) to disinfect drinking water. One or more of these four compounds were detected in drinking-water samples from nearly half of the randomly selected CWSs in the 12-State region during 1993-98 (see fig. 4A and table 9).

It is a general requirement under the SDWA that all surface-water supplied CWSs, and those CWSs supplied by ground water under the direct infl lence of surface water ${ }^{1}$, must disinfect their water. CWSs exclusively supplied by ground water do not need to disinfect their water unless it is a State requirement that they do so. Even where disinfection of ground water is required or practiced, the levels of humic substances that react with chlorine are generally much lower in ground water than in surface water. Conseque'tly, there is a large difference in the occurrence of THMs in drinking water when the source of water is considered (table 14). Nearly 90 percent of the CWSs sufolied by surface water (either exclusively or in combiration with ground-water sources) reported THM concentrations at or above $1.0 \mu \mathrm{g} / \mathrm{L}$, whereas only 26 percent of systems exclusively supplied by ground-water reported similar THM concentrations.

THM occurrence was similarly skewed to larger systems (table 14), as 100 percent of the 31 randomly selected CWSs that serve more than 50,000 people reported THM concentrations at or above $1.0 \mu \mathrm{g} / \mathrm{L}$. The large CWSs are more often supplied by s Irfacewater sources- 87 percent of systems serving more than 50,000 people and 59 percent of systems serving 3,301 to 50,000 people have surface-water sources-whereas only 37 percent of the systems serving 501 to 3,300 people and 6 percent of those serving 25 to 500 people have surface-water sources. The frequency of THM detections for the 12-State area is likely to be positively biased by the lack of data for most (88 percent) of the CWSs in Pennsylvania and for about one-third of the systems in New York. In particular, 86 percent of the 562 CWSs in these two States

\footnotetext{
1."Any water beneath the surface of the ground witr (1) significant occurrence of insects or other macroorganisms, alşe, or large-diameter pathogens such as Giardia lamblia or, (2) significant and relatively rapid shifts in water characteristics such as turbidity, temperature, conductivity, or $\mathrm{pH}$ which closely correlate to climatological or surface-water conditions." (U.S. Environmental Protection Agency, 1994)
} 
that are missing THM data are ground-water supplied, and 76 percent of the systems missing data serve 25 to 500 people. The bulk of the CWSs without THM data, therefore, are among the source and size categories that have comparatively low THM detection frequencies.

Chloroform was the most frequently detected VOC in drinking water in the study area at the $1.0 \mu \mathrm{g} / \mathrm{L}$ reporting level, regardless of source-water type. Chloroform has been consistently one of the most frequently detected VOCs in ambient waters in the Nation-reported in 64 percent of surface-water samples from about 12,000 locations (Staples and others, 1985) as well as detected in about 8 percent of 2,943 wells (Squillace and others, 1999). Chloroform detections in surface waters are generally attributed to upstream discharges of industrial wastewater and sewage-treatment plant effluents (Stangroom and others, 1998), but ground-water detections are partly attributed to infiltration of chlorinated drinking water from lawn and garden irrigation and leaky water mains or sanitary sewers in urban areas (Squillace and others, 1999). Consequently, some of the low level chloroform (or other THM) detections in drinking water in the 12State region may be attributed to the occurrence of THMs in source waters rather than within-system chlorination by CWSs.

Total THM concentrations (the calculated sum of chloroform, chlorodibromomethane, bromodichloromethane, and bromoform concentrations) in 5,850 drinking-water samples with THM detections ranged from 0.1 to $425 \mu \mathrm{g} / \mathrm{L}$. Concentrations in 186 drinkingwater samples ( 3 percent of samples with THM detections at any reporting level) from $46 \mathrm{CWSs}$ equaled or exceeded the $100-\mu \mathrm{g} / \mathrm{L}$ MCL (U.S. Environmental Protection Agency, 1996). The THM MCL requires that the average annual THM concentration in drinking water provided by a water system to be less than 100 $\mu \mathrm{g} / \mathrm{L}$, and thus, it does not strictly apply to individual water samples. The number of samples and systems reporting THM concentrations that equal or exceed the $100-\mu \mathrm{g} / \mathrm{L} \mathrm{MCL}$ is small, considering the more than 15,000 drinking-water samples from 1,543 CWSs analyzed for THMs. The collective population served by these $46 \mathrm{CWSs}$, however, totals 877,021 or about 9 percent of the population served by the set of randomly selected CWSs in the 12 States. Because of concerns that some THMs are probable human carcinogens (Morris and others, 1992; King and Marrett, 1996) and may have other deleterious effects on human health (Waller and others, 1998; Klotz and Pyrch, 1999), the
USEPA, under the 1996 Amendments to the SDWA, will reduce the total THM MCL to $80 \mu \mathrm{g} / \mathrm{L}$ in 2001 and will reduce it further to $40 \mu \mathrm{g} / \mathrm{L}$ in 2005 (U.S. Environmental Protection Agency, 1998e). Reductions in THM concentrations in drinking water are planned by decreasing the amount of residual chlorine required to remain in drinking water as it moves from the t"eatment plant through the distribution system to water consumers. Comparing the THM concentratic ns observed during this study to the planned MCLs indicates that about 8 percent of the samples would exceed the $80-\mu \mathrm{g} / \mathrm{L} \mathrm{MCL}$, and about 30 percent of the samples would exceed the $40-\mu \mathrm{g} / \mathrm{L}$ MCL. Lower THM concentrations are anticipated, however, if residual chlorine levels are decreased in the future.

Median detected total THM concentrations for 702 randomly selected CWSs that reported detectable THMs are compared in figure 8 by source of water. The detected THM concentrations differed significantly (Kruskal-Wallis test $\mathrm{p}<0.0001$ ) for CWSs sur lied by ground water, surface water, or both ground- and surface-water sources. The median THM concentration for the $390 \mathrm{CWSs}$ exclusively supplied by ground water $(2.5 \mu \mathrm{g} / \mathrm{L})$ was significantly less than median concentrations for the CWSs exclusively supplied by surface water $(30.3 \mu \mathrm{g} / \mathrm{L})$ and for CWSs supplied by both sources $(19.9 \mu \mathrm{g} / \mathrm{L})$. A statistically significant difference was also evident for the median THM concentrations between the CWSs exclusively supplied by surface water and those CWSs supplied by' both sources. Median total THM concentrations for seven CWSs (six of these were exclusively surface-water supplied) exceeded the current (2000) $100-\mu \mathrm{g} / \mathrm{L}$ MCL.

Among the four THM compounds, the relative frequency of detection (table 15) was chloroform $>$ bromodichloromethane $>$ chlorodibromomethane>bromoform, which conforms with the ratio of chlorine-to-bromine atoms in each compound. Although bromine is used in some disinfection processes, the occurrence of the brominated compounds in some drinking water probably results from bromine impurities in the chlorine used in the most common disinfection process (Bellar ant others, 1974). For the 702 CWSs with detectable THM concentrations in the study area, chloroform $\left(\mathrm{CHCl}_{3}\right)$ was reported in 84 percent, bromodichloromethane $\left(\mathrm{CHBrCl}_{2}\right)$ in 69 percent, chlorodibromometl ane $\left(\mathrm{CHBr}_{2} \mathrm{Cl}\right)$ in 55 percent, and bromoform $\left(\mathrm{Cl}^{-} \mathrm{Br}_{3}\right)$ in 28 percent. 


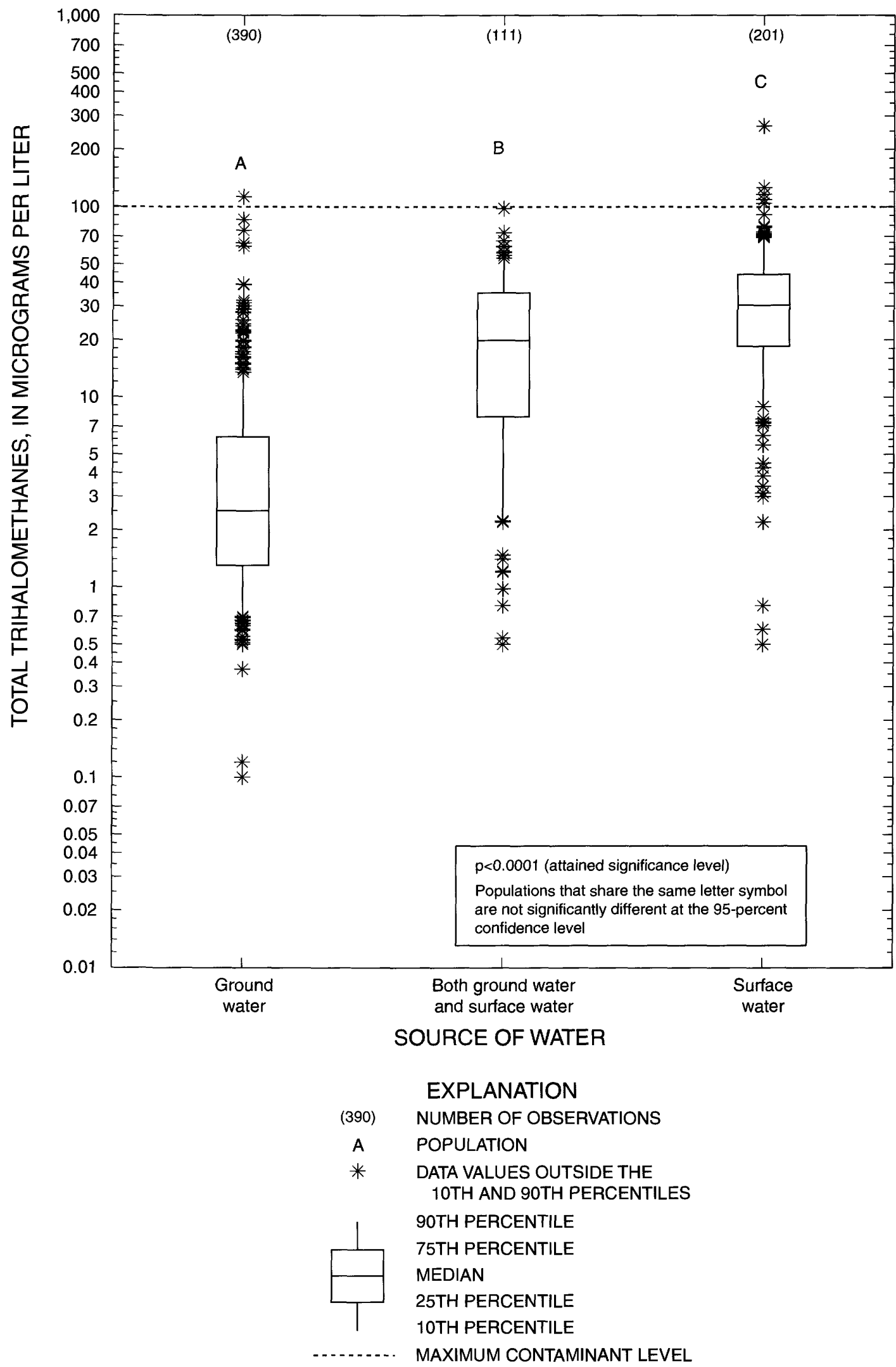

Figure 8. Distribution of median total trihalomethane concentrations in drinking water from randomly selected community water systems in study area compared by source of water. 
Table 15. Frequency of detection and median concentrations of trihalomethanes in drinking water f"om randomly selected community water systems in the study area compared by source of water

\begin{tabular}{|c|c|c|c|c|c|c|}
\hline \multirow[b]{2}{*}{ Trihalomethane } & \multicolumn{3}{|c|}{$\begin{array}{c}\text { Frequency of detection } \\
\text { (percentage of community } \\
\text { water systems) }\end{array}$} & \multicolumn{3}{|c|}{$\begin{array}{l}\text { Median concentration } \\
\text { (micrograms per liter) }\end{array}$} \\
\hline & $\begin{array}{c}\text { Ground } \\
\text { water }\end{array}$ & $\begin{array}{c}\text { Surface } \\
\text { water }\end{array}$ & Both & $\begin{array}{l}\text { Ground } \\
\text { water }\end{array}$ & $\begin{array}{c}\text { Surface } \\
\text { water }\end{array}$ & Both \\
\hline Total trihalomethanes & 32 & 91 & 91 & 2.5 & 30 & 20 \\
\hline Chloroform & 26 & 89 & 87 & 1.6 & 24 & 17 \\
\hline Bromodichloromethane & 20 & 81 & 77 & 1.2 & 4.0 & 3.7 \\
\hline Chlorodibromomethane & 19 & 47 & 57 & 1.0 & 1.5 & 1.4 \\
\hline Bromoform & 12 & 13 & 21 & 1.1 & 0.8 & 1.2 \\
\hline
\end{tabular}

The THM compounds have high co-occurrence among themselves (table 16) as well as broad, lowlevel co-occurrence with other VOCs (appendix 4) - only 8 rarely detected VOCs among the 64 VOCs reported in drinking water in the study area have not cooccurred at least once with a THM compound. For this report, co-occurrence is calculated as the ratio of the number of times a less frequently detected compound occurred to the number of times the more frequently detected compound occurred (when both compounds were measured in the same sample), multiplied by 100 to express the value in percent. For example, bromodichloromethane was detected 2,656 times with 3,758 chloroform detections, and consequently bromodichloromethane co-occurs with 71 percent of the chloroform detections. Generally, if the percentage co-occurrence among VOCs exceeds 20 percent, the compounds are thought to be related in the water sample, possibly because they may come from the same source. Cooccurrence was greater than 20 percent for 10 of the 12 possible THM pairs and was greater than 50 percent for 8 THM pairings. The high degree of co-occurrence among THM compounds is a reflection of the fact that they are commonly generated through the act of chlorinating unprocessed drinking-water. The broad lowlevel (less than 10 percent) co-occurrence of most VOCs with THMs is not related to a commor source but rather reflects the nearly ubiquitous distribution of THMs in drinking water.

Table 16. Co-occurrence of trihalomethane compounds in drinking water from randomly selected community water systems in the study area

[Co-occurrence is calculated as the percentage of samples with detections of compound specified by column that also had detections of compound specified by row; co-occurrence values equal to or greater than 20 percent are shown in bold; NA, not applicable]

\begin{tabular}{lcccc}
\hline & \multicolumn{4}{c}{ Co-occurrence, in percent } \\
\cline { 2 - 5 } Trihalomethane & Chloroform & $\begin{array}{c}\text { Bromodichlo- } \\
\text { romethane }\end{array}$ & $\begin{array}{c}\text { Chlorodibro- } \\
\text { momethane }\end{array}$ & Bromoform \\
\hline Chloroform & NA & 95 & $\mathbf{8 4}$ & $\mathbf{5 8}$ \\
$\begin{array}{c}\text { Bromodichlo- } \\
\text { romethane }\end{array}$ & 71 & NA & $\mathbf{8 9}$ & $\mathbf{6 8}$ \\
$\begin{array}{c}\text { Chlorodibro- } \\
\text { momethane }\end{array}$ & 42 & 61 & NA & $\mathbf{8 3}$ \\
Bromoform & 12 & 18 & $\mathbf{3 3}$ & NA \\
\hline
\end{tabular}




\section{MTBE and Other Gasoline Components}

The gasoline additive MTBE was the sixth most frequently detected VOC contaminant in drinking water from randomly selected CWSs in the Northeast and Mid-Atlantic regions during 1993-98. MTBE was detected in 343 drinking-water samples from 106 CWSs in the region at concentrations ranging from 0.26 to $210 \mu \mathrm{g} / \mathrm{L}$. The lack of any MTBE data for Delaware and Pennsylvania meant that a total of 1,194 CWSs, or just more than half of the 2,110 randomly selected CWSs, have analyzed for MTBE; the MTBE data included 5,510 analyses of drinking-water samples at reporting levels that ranged from 0.1 to $10 \mu \mathrm{g} / \mathrm{L}$. After the trihalomethane compounds, MTBE was the most frequently detected VOC, detected in 8.9 percent of 1,194 randomly selected CWSs that sampled for MTBE at any reporting level and in 7.8 percent of $1,074 \mathrm{CWS}$ s that sampled for MTBE at the $1.0 \mu \mathrm{g} / \mathrm{L}$ level during 1993-98. MTBE was more frequently detected than all other non-THM VOCs at all reporting levels (see appendix 3), and at reporting levels of 10 and $20 \mu \mathrm{g} / \mathrm{L}$, the frequency of MTBE detections exceeded that of bromoform, the least commonly detected trihalomethane.

Although MTBE was detected in drinking water from all 10 States in the region that have analytical data, the frequency of detection at $1.0 \mu \mathrm{g} / \mathrm{L}$ differed significantly (contingency-table test $\mathrm{p}<0.0001$ ) (fig. 9). With detections reported by 21.5 percent of randomly selected CWSs with data for MTBE, New Jersey reported the greatest frequency of MTBE in drinking water at concentrations at or above $1.0 \mu \mathrm{g} / \mathrm{L}$, and Virginia (1.3 percent) reported MTBE least frequently. The frequency of detecting MTBE in drinking water at or above $1.0 \mu \mathrm{g} / \mathrm{L}$ was significantly greater in New Jersey than in Maryland, New York. Vermont, and Virginia. The States with the highest MTBE detection frequencies-New Jersey, F hode Island, and Connecticut-are the three States with the highest average population density (see table 13). As previously shown for any VOC and non-THM VOCs, the occurrence of MTBE also can be statistically related to population density. Twenty percent of the CWSs that have one or more sources in urban areas (population density equal to or greater than 1,000 people per $\mathrm{mi}^{2}$ ) reported detecting MTBE at the 1.0 $\mu \mathrm{g} / \mathrm{L}$ reporting level, whereas less than 6 percent of CWSs with no sources in urban areas contained the gasoline additive (table 14). A contingency-table test for this 3-to-1 distribution rejects the null hypothesis that MTBE detections are independent of population density at $\mathrm{p}<0.0001$. This association of MTE detections in ambient ground waters with urban areas also was observed by Squillace and others (1999) from data largely collected from shallow monitoring wells, as well as by the State of Maine (1998) with data from domestic and public supply wells.

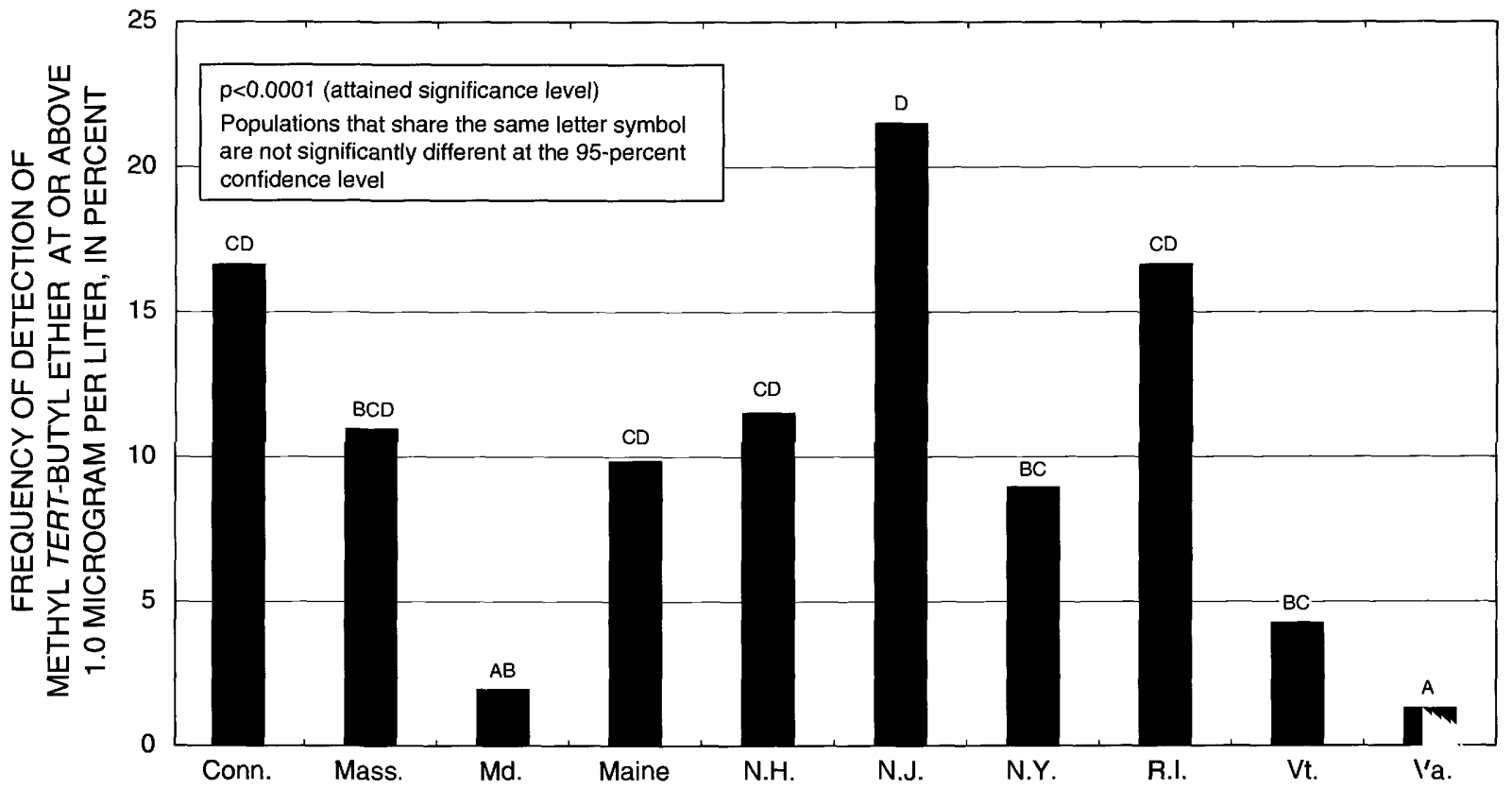

Figure 9. Frequency of detection of methyl tert-butyl ether at or above 1.0 microgram per liter in drinking water from randomly selected community water systems in 10 Northeast and Mid-Atlantic States, 1993-98. (Populations that share the same letter symbol are not significantly different at the 95-percent confidence level; $p=$ the attained significance level.) 
New Jersey, Rhode Island, and Connecticut share another characteristic that has greater bearing on the occurrence of MTBE in drinking water than does population density. These three States, as well as Massachusetts (and Delaware), use substantial amounts of MTBE (greater than 5 percent by volume) in OXY/RFG program areas that extend throughout the entire State. The extent of the OXY/RFG-use areas also includes (or did include for some part of the 1993-98 period) parts of Maine, New Hampshire, New York, Pennsylvania, Maryland, and Virginia (fig. 10). The distribution of sources for CWSs that have been sampled for MTBE and those that have reported MTBE detections also is shown in figure 10 . The frequency of detection of MTBE in drinking water is more than five times greater in the OXY/RFG-use areas for any reporting level, and is seven times greater for concentrations at or above $1.0 \mu \mathrm{g} / \mathrm{L}$, than in the remaining no or low MTBE-use areas. The elevated frequency of MTBE detections in the OXY/RFG areas are statistically greater (contingency-table test $\mathrm{p}<0.0001$ ) than detections in low MTBE-use areas. MTBE concentrations, however, were not significantly different for systems in or out of OXY/RFG-use areas (Wilcoxon rank-sum test $\mathrm{p}=0.3177$ ). The median detected MTBE concentration for the $89 \mathrm{CWS}$ inside OXY/RFG areas with MTBE detections was $1.3 \mu \mathrm{g} / \mathrm{L}$, whereas the median detected MTBE concentration for the $17 \mathrm{CWSs}$ with detections that are outside of OXY/RFG areas was $2.0 \mu \mathrm{g} / \mathrm{L}$.

MTBE was detected at or above $1.0 \mu \mathrm{g} / \mathrm{L}$ in 7.8 percent of CWSs supplied exclusively by ground-water sources and in 2.6 percent of those supplied exclusively by surface-water sources, but the CWSs that use both sources had the most frequent MTBE detections (16 percent). Presumably, this may reflect the propensity for larger systems in urban areas to have both surfaceand ground-water sources, combined with the association of MTBE with urban sources. MTBE detections in drinking water from smaller CWSs that serve predominantly small rural populations were less frequent (but still notably about 6 to 7 percent) than the 36 percent of CWSs that serve more than 50,000 people in urban areas (table 14). The frequent and widespread detection of MTBE in drinking water within a short time (6 years) following its introduction into much of the region in substantial amounts (greater than 5 percent by volume) as a gasoline oxygenate reflects its chemical characteristics (high solubility, low soil adsorption, and low biodegradability) together with its large rumbers and variety of potential sources.

Fortunately, although MTBE detections may be relatively numerous, as with most other VOCs detected in drinking water, concentrations have been generally low. Only 8 percent of the 343 reported MTBE detections and 0.8 percent of 1,194 randomly selected CWSs with data for MTBE have equaled or exceedef the 20$\mu \mathrm{g} / \mathrm{L}$ lower limit recommended by USEPA, and just 2 percent of the CWSs reported concentrations at or above the California 5- $\mu \mathrm{g} / \mathrm{L}$ taste and odor th"eshold. Median detected MTBE concentrations in drinking water for the $106 \mathrm{CWSs}$ reporting MTBE detections were less than $1.0 \mu \mathrm{g} / \mathrm{L}$ about 40 percent of $\mathrm{tl}$ ? time and less than $10 \mu \mathrm{g} / \mathrm{L} 90$ percent of the time.

Information on the concentration of MTBE in drinking water was obtained for additional PW'Ss other than the 1,194 randomly selected CWSs during data compilation efforts for this study. Because of the keen interest in all available information on the occurrence and distribution of MTBE in drinking water, these data were reviewed and are described here. They are not used, however, in any data analysis or projections made for this report because they are largely limited to those States (Maine, Maryland, New Jersey, Rhode Island, and Virginia) that provided more data than re Overall, 374 PWSs, including 106 of the randomly selected CWSs plus 268 other PWSs, have reported detectable concentrations of MTBE in 1,217 drinkingwater samples that range from 0.26 to $3,260 \mu \mathrm{g} / \mathrm{L}$. Median concentrations for the additional 268 PWSs reporting MTBE detections were calculated $\mathrm{c}$ nd compared to the subset of 106 randomly selected CWSs (fig. 11). MTBE concentrations in the set of 268 PWSs with MTBE data are slightly but significantly (Wilcoxon rank-sum test $\mathrm{p}=0.0281$ ) greater than in the randomly selected CWSs. This is likely an artifact of a biased distribution for the set of 268 PWSs with respect to why they were sampled for MTBE. It is krown that samples for MTBE were intentionally collected at some PWSs where gasoline sources (gasoline stations, underground fuel storage tanks) were near water sources and gasoline contamination was known to occur nearby. Although a few of these systems may have been included in the randomly selected CWSs by chance, the random set of CWSs is representative of the population of CWSs in the 12-State area and less likely overstates the occurrence or concentrations of MTBE due to any potential sampling bias. 


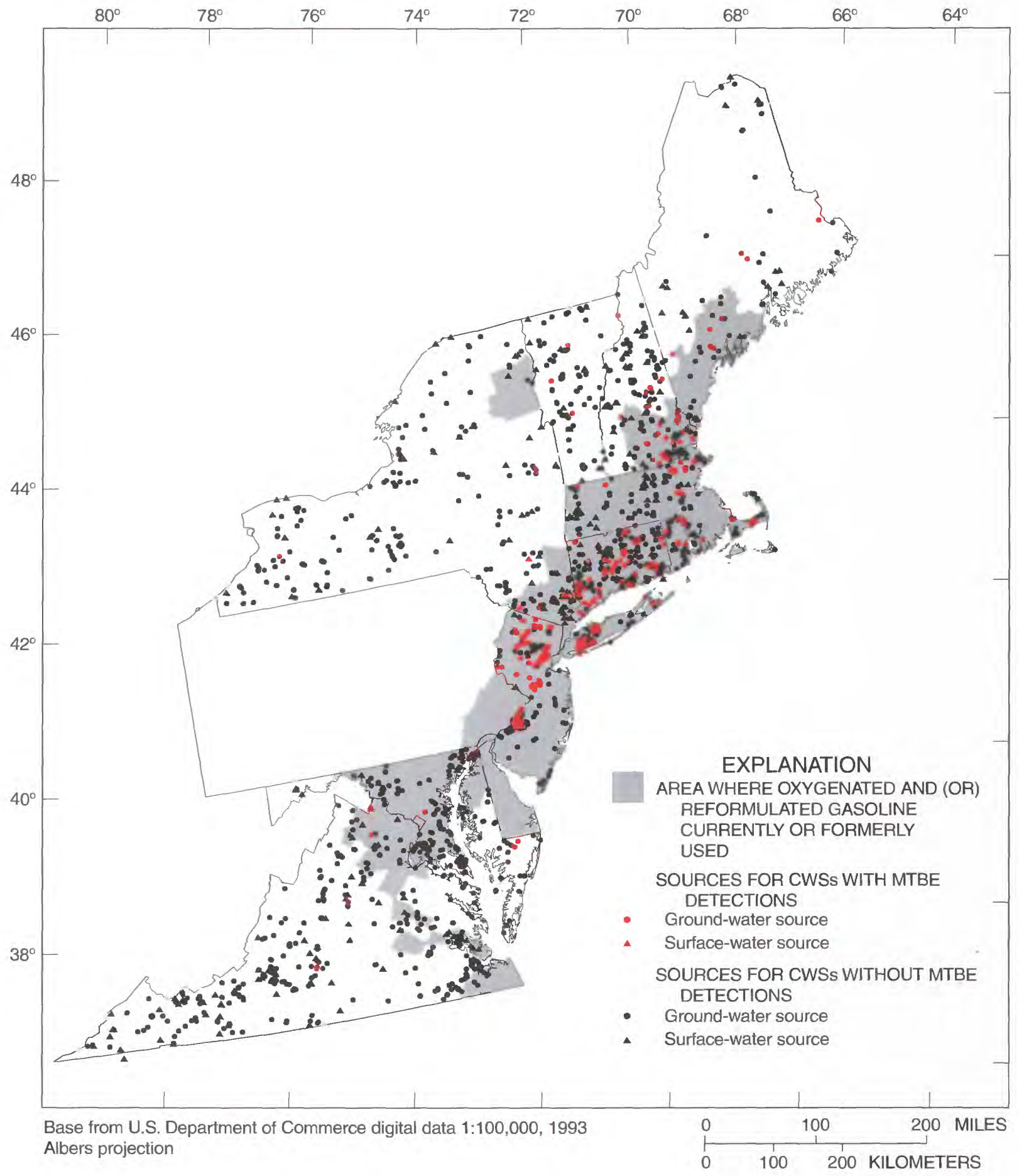

Figure 10. Drinking-water sources for randomly selected community water systems in the study area, showing systems with analytical data and those systems with reported detectable concentrations for methyl tert-butyl ether, in relation to areas where oxygenated and (or) reformulated gasoline is currently or was formerly used (U.S.

Environmental Protection Agency, 1998c, 1998d). 


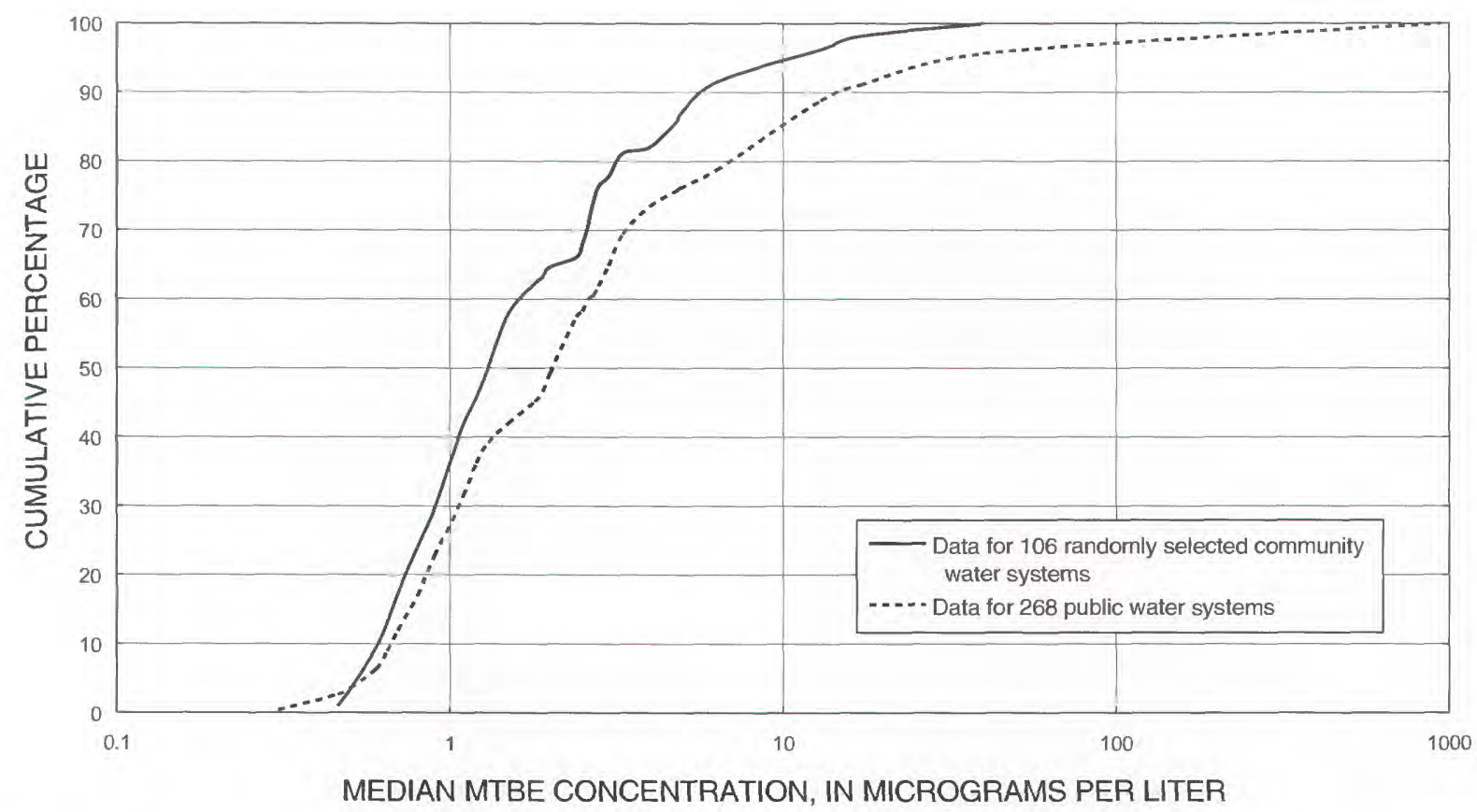

Figure 11. Comparison of cumulative distributions of median methyl tert-butyl ether concentrations detected in drinking water for randomly selected community water systems to selected public water systems in the study area.

In addition to MTBE, 12 other VOCs that have been commonly associated with gasoline sources also were detected in drinking water in the 12-State area (see table 9 and appendix 3). Among the gasoline components and other hydrocarbons associated with gasoline sources (see appendix 1) are benzene, toluene, ethylbenzene, and various xylene isomers $(o-, m-$, and $p$-xylene summed in this report as "total xylenes") that are collectively referred to as BTEX compounds. Total xylenes and toluene were the most frequently detected gasoline compounds after MTBE, reported in 3.2 and 2.5 percent of CWSs, respectively, at or above $1.0 \mu \mathrm{g} / \mathrm{L}$ (fig. 5); ethylbenzene (detected in 2.4 percent of CWSs) and benzene (detected in 0.8 percent of CWSs at or above $1.0 \mu \mathrm{g} / \mathrm{L}$ ) followed. When compared with MTBE, each individual BTEX compound occurs less than half as frequently in drinking water, but collectively (that is, the frequency of detection of any BTEX compound) is comparable to MTBE-8.4 percent of the randomly selected CWSs detected BTEX at any reporting level and 5.8 percent of CWSs reported BTEX concentrations at or above $1.0 \mu \mathrm{g} / \mathrm{L}$. The frequency of detecting any BTEX compound was greater in the OXY/RFG-fuel areas (11 percent of CWSs at any reporting level) than non-OXY/RFG areas (8 percent of CWSs), but the difference is much smaller than for MTBE. This observation is considered to be an artifact of the fact that, as with other VOCs, BTEX is associated with urban areas with high population density $(\mathrm{p}<0.0001)$ and, in general, there is an autocorrelation between the OXY/RFG-fuel areas and urban areas in the 12-State area.

Although BTEX has been relatively widely detected in drinking water, and a few additional gasoline components (naphthalene, $n$-butylbenzene, and 1,3,5-trimethylbenzene) have been detected more rarely, these compounds generally do not co-occur in drinking water with MTBE. Co-occurrence of BTEX and other specific gasoline components with MTBE ranged from 0 to 2.7 percent (table 17), and only 9 of 1,191 of CWSs ( 0.8 percent) reported such co-occurring detections. Co-occurring detections of any BTEX compound with MTBE were reported in only 12 of the 5,406 drinking-water samples ( 0.2 percent) that were analyzed for both VOCs (fig. 12). Also, co-occurring detections at concentrations greater than $20 \mu \mathrm{g} / \mathrm{L}$, which might indicate contamination from a nearby gasoline point source (Moran and others, 1999), were rare. Only 3 samples among the 464 drinking-water samples plotted in figure 13 that contained MTBE, one or more BTEX compounds, or both VOCs, had concentrations of MTBE and BTEX greater than $20 \mu \mathrm{g} / \mathrm{L}$, and all 3 samples were collected from a single CWS. 
Table 17. Co-occurrence of gasoline components in drinking water from randomly selected community water systems in the study area

[Co-occurrence is calculated as the percentage of samples with detections of compound specified by column that also had detections of compound specified by row; co-occurrence values equal to or greater than 20 percent are shown in bold; NA, not applicable; ND, not determined because less than 10 detections of compound specified by column]

\begin{tabular}{lccccccc}
\hline \multirow{2}{*}{$\begin{array}{c}\text { Gasoline } \\
\text { component }\end{array}$} & MTBE & Benzene & $\begin{array}{c}\text { Ethyl- } \\
\text { benzene }\end{array}$ & Toluene & $\begin{array}{c}\text { Total } \\
\text { xylenes }\end{array}$ & $\begin{array}{c}n \text {-Butyl- } \\
\text { benzene }\end{array}$ & $\begin{array}{c}\text { Co-occurrence, in percent } \\
\text { Trimethyl- } \\
\text { benzene }\end{array}$ \\
\cline { 2 - 8 } MTBE & NA & $\mathbf{2 6}$ & 5.7 & 2.7 & 11 & ND & ND \\
Benzene & 2.4 & NA & 3.7 & 7.1 & 7.6 & 0 & 0 \\
Ethylbenzene & 0.6 & 5.8 & NA & $\mathbf{2 3}$ & $\mathbf{4 7}$ & 4.5 & 8.7 \\
Toluene & 0.6 & 17 & $\mathbf{3 7}$ & NA & $\mathbf{2 7}$ & 4.5 & 4.3 \\
Xylenes, total & 2.7 & $\mathbf{2 5}$ & $\mathbf{7 3}$ & $\mathbf{3 3}$ & NA & ND & ND \\
Naphthalene & 0.7 & 2.5 & 1.9 & 1.1 & 1.5 & ND & ND \\
$n$-Butylbenzene & 0 & 0 & 1.8 & 0.9 & 0 & NA & $\mathbf{7 0}$ \\
$1,3,5$-Trimethylbenzene & 0 & 0 & 3.5 & 0.9 & 6.3 & $\mathbf{7 3}$ & NA \\
\hline
\end{tabular}

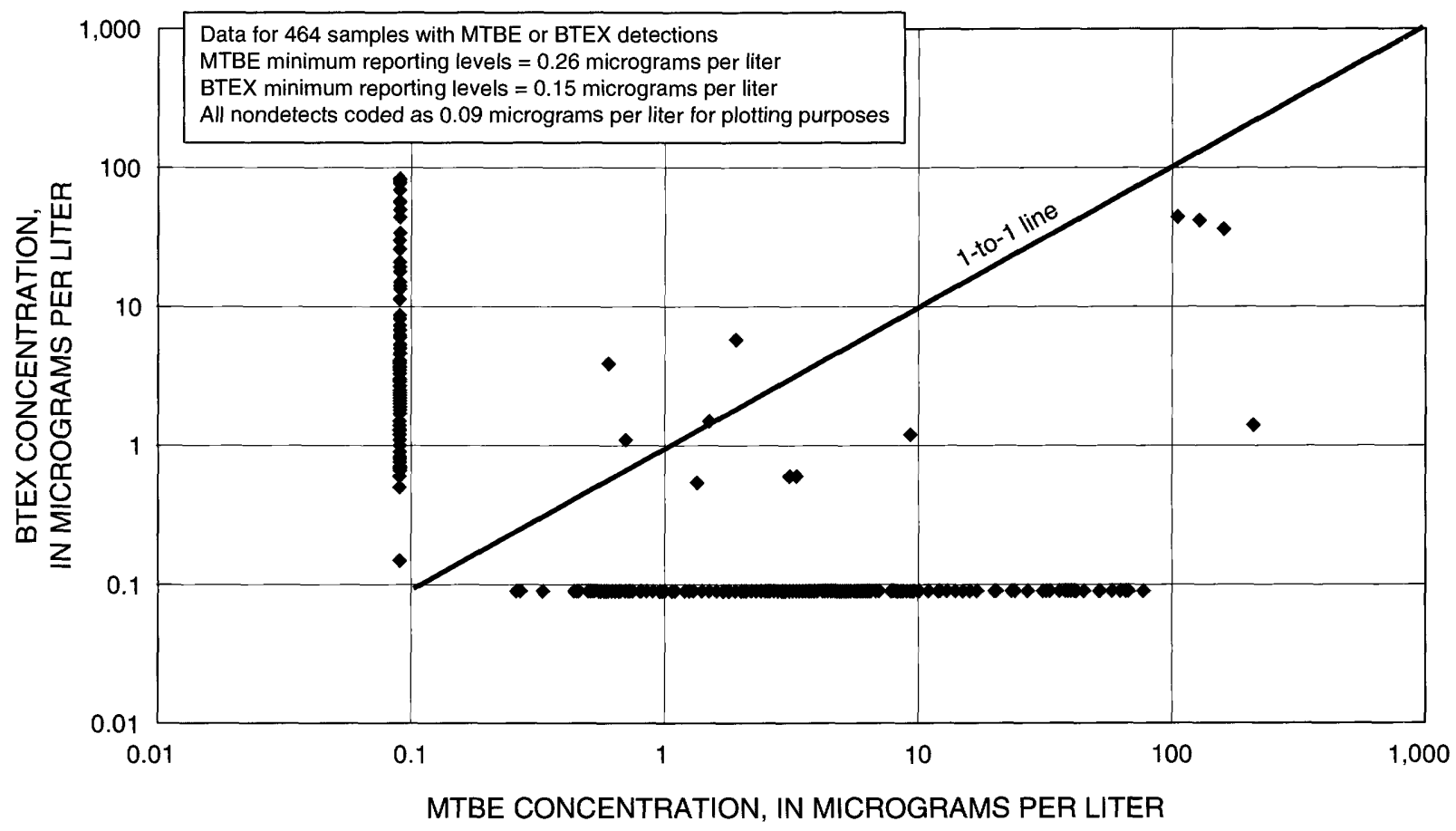

Figure 12. Comparison of methyl tert-butyl ether (MTBE) concentrations to the sum of the concentrations of benzene, ethylbenzene, toluene, and xylenes (BTEX) in drinking-water samples from randomly selected comm unity water systems in the study area. (Data for 464 samples with MTBE or BTEX detections; minimum reporting levels $=0.26$ micrograms per liter $(\mu \mathrm{g} / \mathrm{L})$ for MTBE and $0.15 \mu \mathrm{g} / \mathrm{L}$ for BTEX; all nondetects coded as $0.09 \mu \mathrm{g} / \mathrm{L}$ for plotting purposes.) 
Co-occurrence among the other gasoline components detected in drinking water (table 17, appendix 4) was generally more extensive. Associations between two pairs of gasoline components-total xylenes with ethylbenzene, and 1,3,5-trimethylbenzene with $n$ butylbenzene-were observed more than 70 percent of the time. Associations of other gasoline contaminants also were observed in drinking-water samples, with cooccurrence exceeding 20 percent for ethylbenzene with toluene and total xylenes, toluene with total xylenes, and total xylenes with benzene.

The question can be raised as to why MTBE, which is widely detected in drinking water, does not generally co-occur with other gasoline contaminants, which have also been reported at comparable detection frequencies, particularly because they have often been found together in ground water at gasoline spills. It is possible that, because of the conservative transport properties of MTBE, some MTBE detections may represent the distal portions of gasoline contaminant plumes that may ultimately affect drinking-water sources, given sufficient time and stress on the aquifer (Johnson and others, 2000). A general consensus is that MTBE occurs without other gasoline contaminants because it is essentially recalcitrant relative to the highly biodegradable BTEX compounds. However, it is also possible that some BTEX or other gasoline contaminants may have been removed by water filtration or treatment processes where they may have been applied (although it is unlikely that such treatment processes would remove only BTEX and not remove MTBE). The lack of a substantial co-occurrence of MTBE with other gasoline components in drinking water, together with the generally low concentrations reported, indicates that most detections may not be caused by nearby gasoline point sources.

It is likely, given the variety of possible sources of MTBE other than leaking underground storage tanks (Delzer and others, 1996; Pankow and others, 1997; Baehr and others, 1999; Hunter, 1999; Moran and others, 1999; Robbins and others, 1999), that the bulk of the detections may have been derived from mobile, atmospheric, or other diffuse nonpoint sources that could produce low-level contamination of drinking- water with MTBE without introducing other gasoline components in substantial amounts. The combination of multiple sources of MTBE together with its rather unique transport properties leads to the conclusion that the extent of contamination of drinking water from gasoline is substantially greater with the use cf MTBE than would have occurred had this oxygenate never been added to gasoline. It is also possible, given the widespread use of xylenes and toluene, partic larly in numerous household and commercial products, that some BTEX detections in drinking water that occur without MTBE may represent sources for these chemicals other than fuels. In addition, toluene and xylenes have been noted in some drinking water systems following installation of water tank lining materials.

Although the co-occurrence of gasoline components is not extensive in drinking water, 44 percent of the 343 samples with MTBE detections contained at least one other VOC. Among the VOCs detected with MTBE, solvents were most prominent (accounting for 58 percent of the co-occurring compounds), followed by trihalomethanes (about 33 percent of co-occurring compounds). BTEX compounds were a distant third, accounting for about 5 percent of all VOCs tl at cooccurred with MTBE, and about 4 percent were refrigerants, fumigants or other VOCs used mainly in the manufacture of organic chemicals (see appendix 4).

As a footnote to the occurrence of gascline components in drinking water in the 12-State area, the authors note that only one State had any data for any other gasoline oxygenate compound. The compound tert-amyl methyl ether (TAME) was reportedly detected in eight drinking-water samples from three PWSs in Virginia in 1997 and 1998. TAME concentrations ranged from 0.6 to $19.1 \mu \mathrm{g} / \mathrm{L}$. MTBE also was reported in all eight of the drinking-water samples that contained TAME, and the MTBE concentrations were elevated at 6.2 to $387 \mu \mathrm{g} / \mathrm{L}$. The three PWSs were not among the randomly selected CWSs inventoried for this study, and no TAME data were available for the randomly selected CWSs. TAME also has been associated with MTBE in water samples collected from four lakes in New Jersey where the use of gasoline-powered watercraft is prevalent (Baehr and Zapecza, 1998). 


\section{Solvents}

Solvents were the third most frequently detected group of VOCs in drinking water in the 12-State area. Included among the VOCs classified as solvents for this report are several chemicals that are widely used in industrial, commercial, and residential applications and are frequent contaminants in ambient ground water (Squillace and others, 1999) and drinking water (Westrick and others, 1984; Mackay and Smith, 1993). Among the group of VOCs classified as solvents are toxic chemicals with potentially severe, well documented human health impacts, and drinking-water regulations have been promulgated for these contaminants (U.S Environmental Protection Agency, 1996).

Twenty-seven of 34 solvents sampled for in drinking water in the 12-State area have been detected at least once (see table 9), and 23 of these were detected at concentrations equal to or exceeding $1.0 \mu \mathrm{g} / \mathrm{L}$ (see fig. 4). VOCs are classified as solvents (for this report) on the basis of their predominant use or most likely source as drinking-water contaminants. Three compounds widely used in industrial and commercial applications - 1,1,1-trichloroethane, trichloroethylene, and tetrachloroethylene - were the most frequently detected solvents in drinking water, each reported in about 5 percent of the CWSs (table 9 and appendix 3 ). Collectively, solvents were detected in 3,080 drinkingwater samples, or about 17 percent of the nearly 18,000 samples analyzed for one or more of these compounds, and in 34 percent of the 8,955 drinking-water samples with any VOC detection. Overall, the frequency of detecting a solvent VOC in drinking water was 14 percent -304 of the 2,097 randomly selected CWSs that analyzed for solvents reported one or more of the 27 solvents at any detectable concentrations in drinking water - and 9.8 percent ( 206 of 2,097 CWSs) at the 1.0 $\mu \mathrm{g} / \mathrm{L}$ reporting level.

The distribution of randomly selected CWSs that have reported detectable solvent concentrations is strongly associated with high population-density, urban areas (fig. 13). One-third of the CWSs that have one or more sources in an urban area reported solvent detections, compared to about 12 percent of CWSs that have no sources in urban areas. A contingency-table test for the hypothesis that solvent detections are independent of population density was rejected at $p<0.0001$. The frequency of solvent detections at or above $1.0 \mu \mathrm{g} / \mathrm{L}$ ranged from just 1.2 percent of CWSs in Vermont to more than 20 percent of CWSs in Massachusetts, New Jersey, and Rhode Island (fig. 14). Detections of solvents at concentrations equal to or greater than 1.0 $\mu \mathrm{g} / \mathrm{L}$ in 28 percent of CWSs in Massachusetts was significantly greater than in all eleven other States.

Most solvent concentrations were less than 5.0 $\mu \mathrm{g} / \mathrm{L}$, but eight of the solvents detected in drinking water were reported at concentrations that equaled or exceeded an MCL. About 3 percent of all trichloroethylene and tetrachloroethylene analyses indicated concentrations that were above MCLs in drinking water, and some concentrations have been more than 100 times greater than the 5.0- $\mu \mathrm{g} / \mathrm{L}$ MCLs. Concentrations as great as $930 \mu \mathrm{g} / \mathrm{L}$ of trichloroethylene and 640 $\mu \mathrm{g} / \mathrm{L}$ of tetrachloroethylene have been reported, but nearly all of these high concentrations were reported by six CWSs. Concentrations of the other six VOCs - carbon tetrachloride, 1,2-dichloroethane, 1,1dichoroethene, cis-1,2-dichloroethene, dichloromethane, and 1,2-dichloropropane-have exceeded their MCLs in only a very small fraction of drinkingwater samples.

The extent of co-occurrence among solvents is greater than other groups of VOCs with the exception of the disinfectant by-products. Half $(1,537)$ of the 3,080 drinking-water samples with solvent detections contained more than 1 solvent VOC. Frequently, three to six solvents may co-occur in a drinking-water sample, with as many as eight compounds reported in a few samples. Among 10 of the most frequently detected solvents (table 18), 9 compounds co-occur with at least 1 other solvent 20 percent of the time or more, and the percentage of co-occurrence reaches as high as 87 percent of 1,1-dichloroethane detections with 1,1,1-trichloroethane. One reason for their frequent co-occurrence is that multiple solvents are often combined in the formulation of cleaning and degreasing agents, dry cleaning fluids, and other products containing solvents that have widespread industrial, commercial, or residential use. Another reason for their co-occurrence is that a number of the solvents, particularly cis- and trans-1,2-dichloroethene, 1,1dichloroethene, and dichloromethane, are transformation products and degradates of parent solvent compounds, such as tetrachloroethylene, trichloroethylene, and 1,1,1-trichloroethane. 


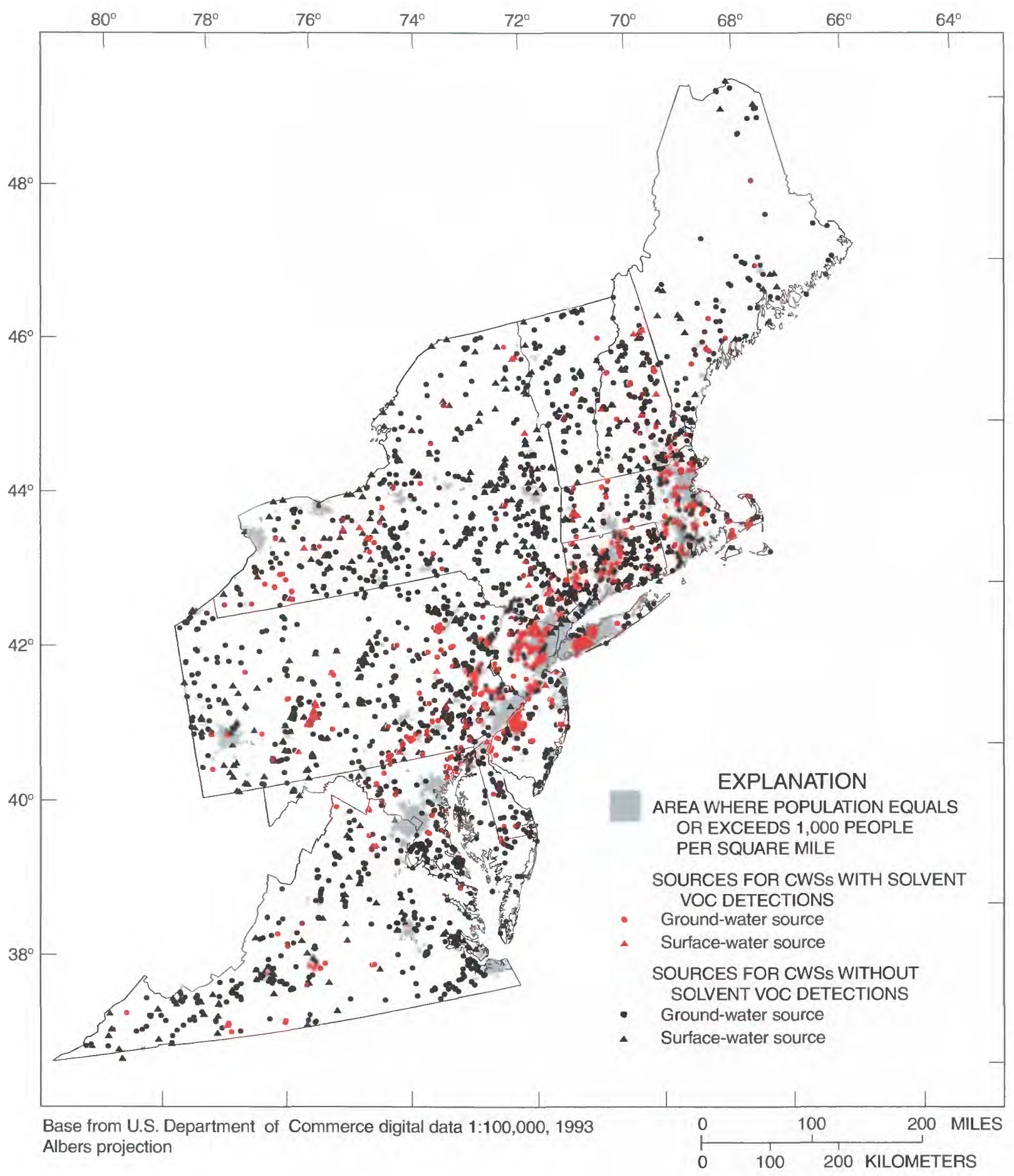

Figure 13. Drinking-water sources for randomly selected community water systems in the study area, showing systems with analytical data and systems with reported detectable concentrations of any solvents, in relation to urban land use. 


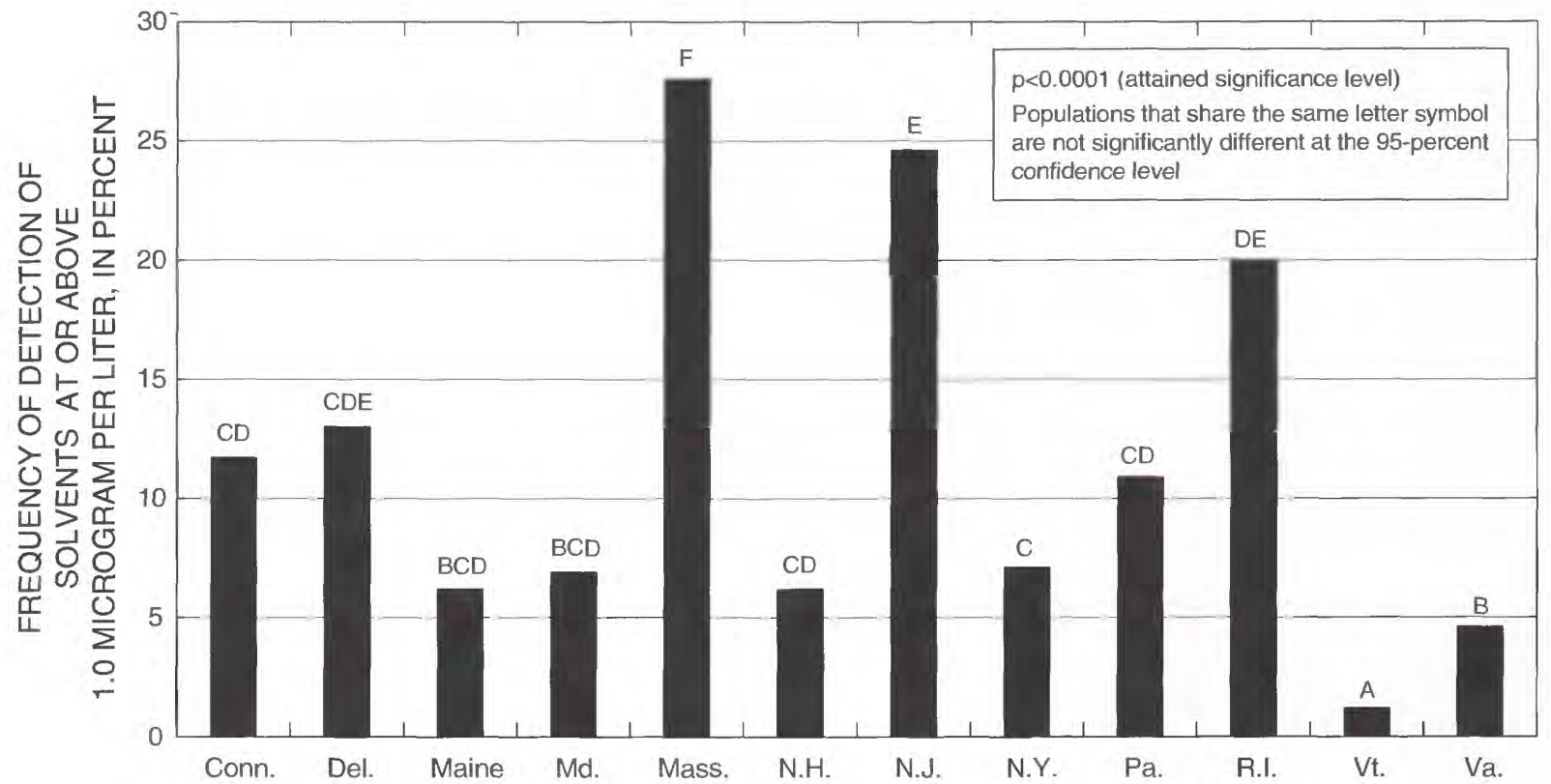

Figure 14. Frequency of detection of solvents at or above 1.0 microgram per liter in drinking water from randomly selected community water systems in the study area, 1993-98. 


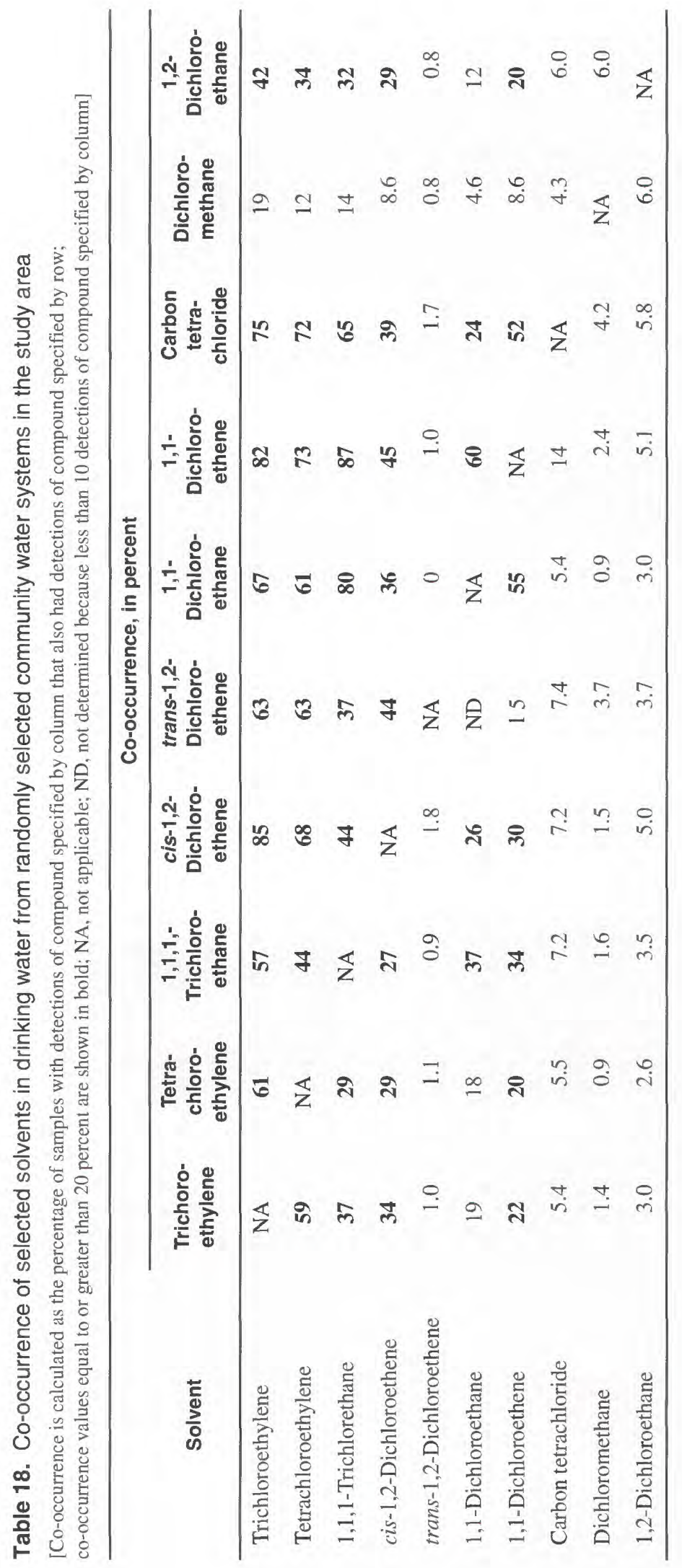




\section{Other VOCs}

In addition to disinfectant by-products, gasoline components, and solvents, other VOCs reported in drinking water in the 12-State area included compounds used mostly as fumigants, refrigerants, or in the manufacture of other chemicals. Collectively, these compounds were detected less frequently than the former groups of VOCs, but several were detected in more than 1 percent of the randomly selected CWSs at any reporting level (table 9), and the refrigerant dichlorodifluoromethane was detected in more than 1 percent of CWSs at concentrations equal to or above $1.0 \mu \mathrm{g} / \mathrm{L}$ (see fig. 4).

Seven of the 84 VOCs represented in the drinking-water data (appendix 1) have been used as pesticide fumigants to destroy insects, bacteria, or rodents in agricultural fields and storage facilities and in some commercial, industrial or even residential settings. Five of the fumigant VOCs were detected in drinking water in the 12-State area and two of these-dibromochloropropane (DBCP) and ethylene dibromide (EDB) — were reported in almost 2 percent of the randomly selected CWSs (table 9). There is a strong degree of co-occurrence of DBCP and EDB in drinking water and both are present in more than 76 percent of the 33 samples with detects of either. Concentrations of DBCP and EDB have exceeded the MCLs of 0.2 and $0.05 \mu \mathrm{g} / \mathrm{L}$, respectively, in a few randomly selected CWSs (see table 8). Although the frequency of fumigant detections is almost twice as great (4.2 percent) for CWSs with sources in urban areas than for CWSs with sources only in rural areas (2.5 percent), the difference is not statistically significant (contingency-table test $p=0.1594$ ). Many fumigant detections were reported by CWSs in rural parts of Delaware, New York, Pennsylvania, and Vermont (fig. 15) where the chemicals may have had agricultural applications. EDB previously was used widely as a scavenger for lead in gasoline but the drinking-water data indicated no co-occurrence of EDB with any gasoline components.

Three VOCs detected in drinking water-chloromethane, dichlorodifluoromethane, and fluorotrichloromethane-are generally associated with their use as refrigerants. Dichlorodifluoromethane, also known commonly as Freon 12 or CFC 12, was the most frequently detected of the three refrigerants, reported in 1.2 percent of the randomly selected CWSs at any reporting level (table 9). It also co-occurred in 61 percent of the samples that contained fluorotrichloromethane. Overall, the three refrigerants were detected in just 3 percent $(55$ of 1,673) of randomly selected CWSs, but they were reported in 10 percent of CWSs with sources in urban areas. When compared to the low detection frequency ( 2 percent) in those CWSs with rural sources only, the refrigerants also were related significantly (contingency-table test $p<0.0001$ ) to high population-density urban areas. Refrigerant detection frequencies were somewhat lower at the $1.0-\mu \mathrm{g} / \mathrm{L}$ reporting level (2 percent of CWSs overall; 7 percent in urban areas, and 1.4 percent in rural areas) yet the relation to urban land use persists $(p<0.0001)$.

Eleven of the 18 compounds used primarily in the synthesis of other organic chemicals were reported in drinking-water samples from the randomly selected CWSs during 1993-98, but most of these were reported by less than 10 systems (see table 9). Collectively, organic synthesis compounds were detected in 2 percent $(42$ of 2,098$)$ of randomly selected CWSs at any reporting level, and in 1.1 percent $(24$ of 2,098) of CWSs at the $1.0 \mu \mathrm{g} / \mathrm{L}$ reporting level. The occurrence of organic synthesis VOCs also is significantly related to urban areas - 7 percent of the CWSs with sources in urban areas reported their detection compared to 1.3 percent of systems in rural areas. A contingency-table test for the independence of detections of organic synthesis compounds in relation to population density rejected the null hypothesis at $\mathrm{p}<0.0001$. 


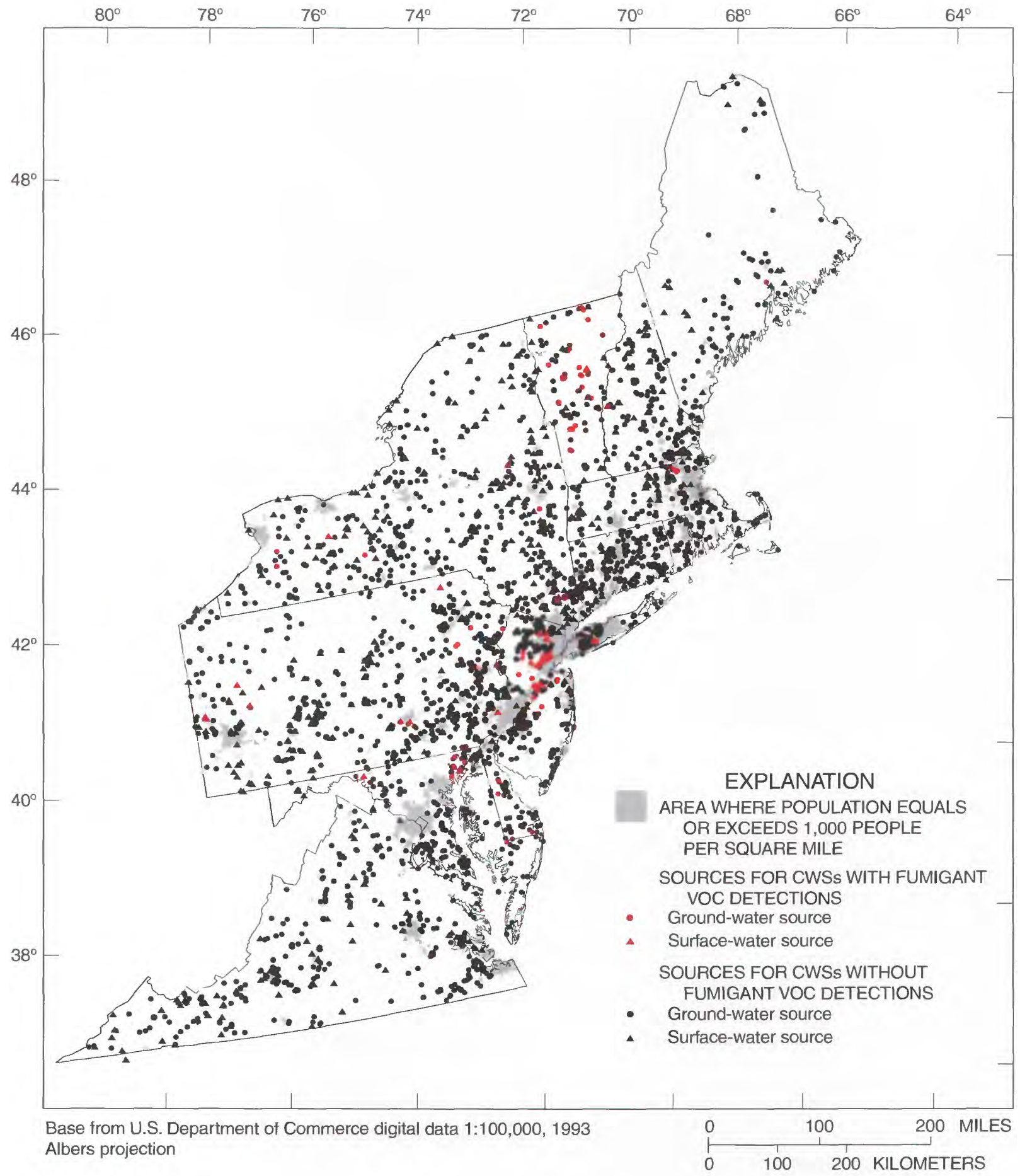

Figure 15. Drinking-water sources for randomly selected community water systems in the study area, showing systems with analytical data and systems with reported detectable concentrations of any fumigants, in relation to urban land use. 


\section{POTENTIAL HUMAN EXPOSURE TO VOCS IN DRINKING WATER}

Information on the actual number of people served by the randomly selected CWSs in the 12-State area who may have been exposed to VOCs in their drinking water during 1993-98 can be determined from the drinking-water data and information coded in the SDWIS database. Furthermore, because the selection of CWSs for this study was random and designed to represent the overall population of people served by all CWSs in the 12 States, the frequency of detection of VOCs in drinking water determined for the random sample can be used to project the overall number of systems and people likely to have been similarly affected during the same time period. The tabulation, on the basis of the random data, of the number of people potentially exposed to VOCs in drinking water, and to an even greater extent the projection of that information to the larger population, should be considered as only approximations of the actual numbers.

Several factors can affect the veracity these estimates, including the accuracy and completeness of the random data, areal and temporal variations of source-water quality and use, residence time and routing of finished water in CWSs' distribution systems, and the application and effectiveness of water-treatment processes.

Exposure, as used in this report, simply refers to the occurrence of a VOC at least once in drinking water supplied to a known population. Tabulations of known populations served, and projections of potential populations served, by CWSs with VOCs present in their drinking water are measures of acute exposure. It is beyond the scope of this study, and perhaps beyond the capacity of the available data, to provide an estimate of chronic exposure of all or part of the population served by CWSs in the 12-State area for any extended period of time. Well-documented data on the levels and variability of VOCs in drinking water over time would be needed to calculate chronic exposure of the population served and to interpret the risk to human health associated with that exposure. The information provided in this report on the known and estimated number of people in the study area potentially exposed to VOCs in their drinking water is intended to identify the scope and magnitude of that potential exposure so that Federal, State, and local water-resource managers and public drinking-water consumers can make informed decisions to protect the resource and human health.

\section{Actual Population Served by Randomly Selected CWSs}

The actual number of people served by randomly selected CWSs that have reported detections of VOCs and, therefore, who may have been exposed at some time during 1993-98, can be tabulated from the random data. The number of people served by CWSs that have reported any detectable concentrations of each of the 64 VOCs found in drinking water is presented in table 19. The tabulation shows, for example, that 589 of the randomly selected CWSs, which collectively serve more than 7 million people, have reported chloroform at some detectable concentration in drinking-water samples during 1993-98. In addition to chloroform, a dozen other VOCs were detected in drinking water supplied by CWSs that collectively served more than 1 million people. The four individual THMs plus total THMs were the top five VOCs in drinking water with respect to the greatest numbers of people potentially exposed; each of the disinfectant by-products and the sum of the four THMs were detected in drinking water supplied to more than 2.5 million people. The commonly detected solvents-trichloroethylene, 1,1,1-tricloroethane, tetrachloroethylene, and cis-1,2dichloroethene-plus MTBE and three of the BTEX compounds-total xylenes, ethylbenzene, and toluene-round out the remaining eight VOCs detected in drinking water supplied to more than 1 million people by randomly selected CWSs. Conversoly, five VOCs-carbon disulfide, cis-1,3-dichloropronene, hexachlorobutadiene, isopropylbenzene, and tetrahydrofuran - have been detected only in drinking water supplied by CWSs that serve 1,000 or fewer feople. It is important to remember, however, that differences in the extent and consistency of the analytical coverage of the VOCs in drinking water may result in substantial underreporting of population served by randomly selected CWSs with detections of some VOCs. Clearly, exposure numbers for compounds like carbon disulfide and tetrahydrofuran that have been analyzed ly less than 10 percent of the 2,110 randomly selecte $\mathrm{CWSs}$ must be reviewed with considerable caution. 
Table 19. Population served by randomly selected community water systems in the study area with detections of 64 volatile organic compounds in drinking water, 1993-98

[CWSs, community water systems]

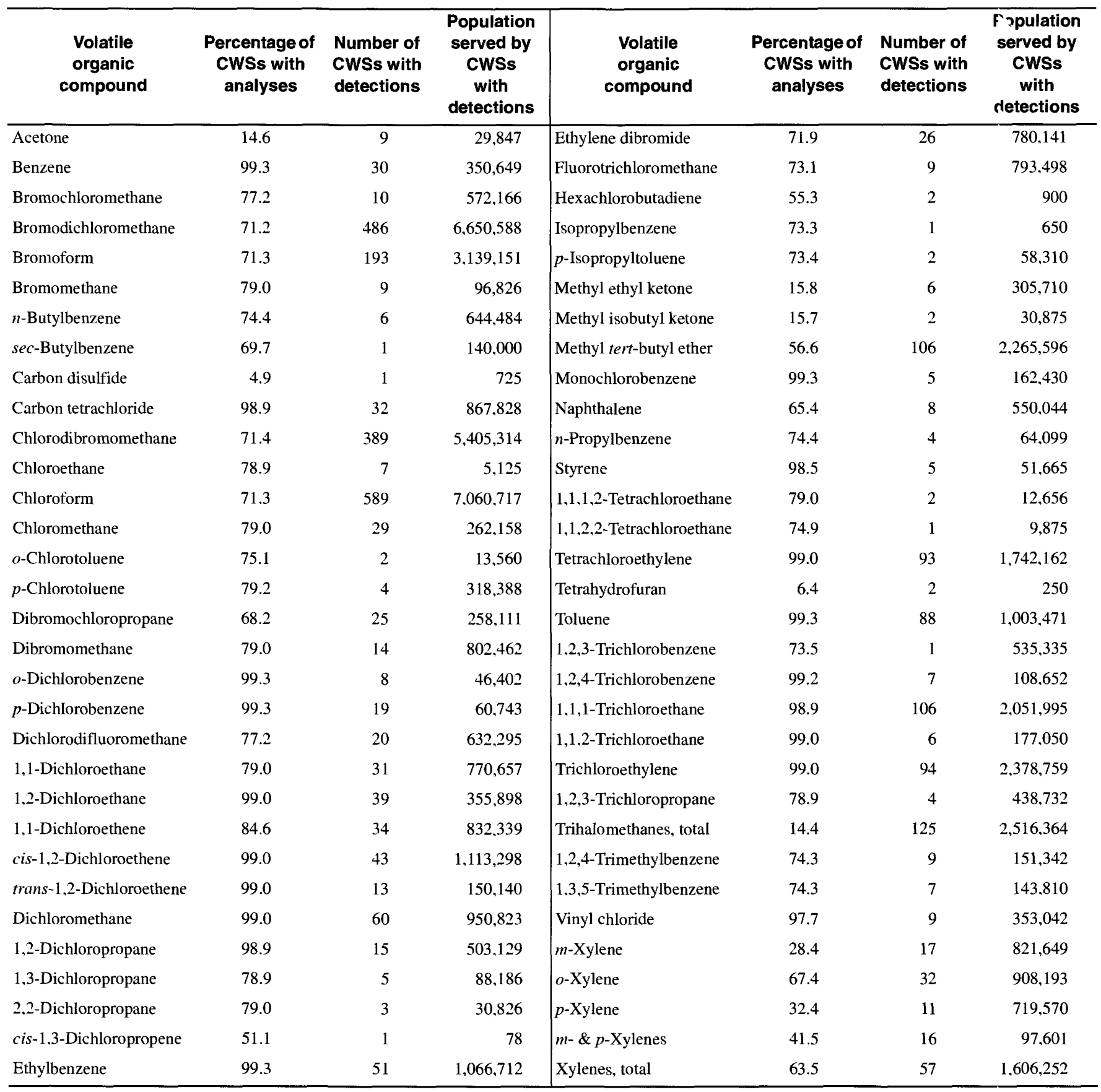


The number of people served by randomly selected CWSs that have reported detections of VOCs, THMs, non-THM VOCs, and MTBE in drinking-water samples at any concentration and at the $1.0-\mu \mathrm{g} / \mathrm{L}$ reporting level during $1993-98$ is summarized in table 20 for each of the 12 States in the study area. The tabulation shows that about 92 percent of the 9.6 million people served by the 2,110 randomly selected CWSs may have been exposed to one or more VOCs (in particular THMs) in their drinking water during this period. Most of the affected population was included when censoring the data at the $1.0-\mu \mathrm{g} / \mathrm{L}$ reporting level; 8.7 million people, or 90 percent of population served by the randomly selected CWSs may have been exposed to one or more of the 54 selected VOCs at concentrations at or above $1.0 \mu \mathrm{g} / \mathrm{L}$. Although less than half the CWSs contained a VOC at detectable concentrations, the high percentage of people served by randomly selected CWSs who may have been exposed to VOCs reflects (1) the large percentage of the population that is served by the large and very large CWSs in urban areas that are supplied by surface-water sources (or both ground- and surface-water sources), and (2) the occurrence of at least one VOC (generally trihalomethane disinfectant by-products) in nearly all of these larger, surface-water-supplied systems (see table 14).

Approximately 5.3 million people, or about half of the population served by the randomly selected CWSs in this study, may have been exposed to VOCs other than THMs; 4.5 million of these people may have been exposed to non-THM VOCs at concentrations at or above $1.0 \mu \mathrm{g} / \mathrm{L}$ (table 20 ). The large number of people served by CWSs with non-THM VOCs in their drinking water also reflects the propensity for nonTHM VOC detections among larger systems with surface-water sources (see table 14). Non-THM detections also were more common in States with more extensive urban areas (see table 13). Variability among the States in the percentage of population that may have been exposed to non-THM VOCs in their drinking water reflects differences in urbanization and population density in the 12-State region as well as differences in reporting levels, analytical coverage, and period of record.

The population served by CWSs with a reported detection of MTBE in their drinking water also is tabulated in table 20. Approximately 2.3 million paople, or about one-third of the population served by CWSs (with available data on MTBE) may have been exposed to MTBE at least once in their drinking water during 1993-98, and most of those people ( 2 million) may have been exposed to concentrations of $1.0 \mu \mathrm{g} / \mathrm{L}$ or greater. The 2.3 million people are about one-auarter of the entire population served by the randomly selected CWSs in the 12-State area. No data, however, are available on the occurrence of MTBE in the drinking water supplied to almost 3 million people served by 916 CWSs or about 30 percent of the population served by the 2,110 CWSs. Consequently, if the 34 percent of the population served by CWSs with MTBE data that were potentially exposed to MTBE is projected for the overall population served by the 2,110 CWSs, then the number of people potentially exposed to MTPE in the random sample is approximately 3.3 million people. Differences in the number of people potentially exposed to MTBE from state-to-state reflect the same factors described above for other VOCs, but also reflect differences in each State's participatior. and the geographic extent of their participation, in the OXY/RFG-fuel programs.

The population served by the 6 percent of randomly selected CWSs in the 12-State area reporting concentrations of VOCs that equaled or exceeded drinking-water regulations or recommendations was $2,622,646$ people (see table 8). Four of the 13 VOCs that exceeded MCLs- including total trihalomethanes, the solvents tetrachloroethylene and trichloroethylene, and the fumigant pesticide ethylene dibromide-were reported by randomly selected CWSs that collectively serve about one-half million people or more. 
Table 20. Population served by randomly selected community water systems reporting detectable concentrations of volatile organic compounds in drinking water in the study area, 1993-98

[Percentage of population served by CWSs with any VOC, THMs, non-THMs, or MTBE detected is number of people served by CWSs with detections divided by number of people served by CWSs with available data for the specified VOC category and reporting level. Percentage values are rounded. CWSs, community water systems; VOC, volatile organic compound; THM, trihalomethane; non-THM, volatile organic compounds exclusive of trihalomethanes; MTBE. methyl tert-butyl ether; -, not determined]

\begin{tabular}{|c|c|c|c|c|c|c|c|c|}
\hline \multirow[b]{3}{*}{ State } & \multicolumn{8}{|c|}{ Number of people (percentage of population served) } \\
\hline & \multicolumn{2}{|c|}{ VOC detections } & \multicolumn{2}{|c|}{ THM detections } & \multicolumn{2}{|c|}{ Non-THM detections } & \multicolumn{2}{|c|}{ MTBE detect' ons } \\
\hline & $\begin{array}{l}\text { Served by } \\
\text { CWSs with } \\
\text { any VOC } \\
\text { detections }\end{array}$ & $\begin{array}{c}\text { Served by } \\
\text { CWSs with } \\
\text { VOC } \\
\text { detections } \\
\text { at or above } \\
1.0 \mu \mathrm{g} / \mathrm{L}\end{array}$ & $\begin{array}{c}\text { Served by } \\
\text { CWSs with } \\
\text { THM } \\
\text { detections }\end{array}$ & $\begin{array}{c}\text { Served by } \\
\text { CWSs with } \\
\text { THM } \\
\text { detections } \\
\text { at or above } \\
1.0 \mu \mathrm{g} / \mathrm{L}\end{array}$ & $\begin{array}{c}\text { Served by } \\
\text { CWSs with } \\
\text { non-THM } \\
\text { detections }\end{array}$ & $\begin{array}{c}\text { Served by } \\
\text { CWSs with } \\
\text { non-THM } \\
\text { detections } \\
\text { at or above } \\
1.0 \mu \mathrm{g} / \mathrm{L}\end{array}$ & $\begin{array}{c}\text { Served by } \\
\text { CWSs with } \\
\text { MTBE } \\
\text { detections }\end{array}$ & $\begin{array}{c}\text { Served by } \\
\text { CWSs with } \\
\text { MTBE } \\
\text { detections } \\
\text { at or above } \\
1.0 \mu \mathrm{g} / \mathrm{L}\end{array}$ \\
\hline Conn. & $\begin{array}{r}939,034 \\
(98)\end{array}$ & $\begin{array}{r}938,374 \\
(98)\end{array}$ & $\begin{array}{r}933,786 \\
(97)\end{array}$ & $\begin{array}{r}933,126 \\
(97)\end{array}$ & $\begin{array}{r}488,928 \\
(51)\end{array}$ & $\begin{array}{r}488,268 \\
(51)\end{array}$ & $\begin{array}{r}373,439 \\
(39)\end{array}$ & $\begin{array}{r}363,564 \\
(38)\end{array}$ \\
\hline Del. & $\begin{array}{r}148,941 \\
(80)\end{array}$ & $\begin{array}{r}145,382 \\
(78)\end{array}$ & $\begin{array}{r}148,842 \\
(80)\end{array}$ & $\begin{array}{r}145,382 \\
(78)\end{array}$ & $\begin{array}{r}144,026 \\
(77)\end{array}$ & $\begin{array}{r}143.591 \\
(77)\end{array}$ & - & - \\
\hline Maine & $\begin{array}{r}46,086 \\
(39)\end{array}$ & $\begin{array}{r}45,461 \\
(38)\end{array}$ & $\begin{array}{r}36,849 \\
(31)\end{array}$ & $\begin{array}{r}36,849 \\
(31)\end{array}$ & $\begin{array}{r}9.237 \\
(7.8)\end{array}$ & $\begin{array}{l}8,612 \\
\quad(7.3)\end{array}$ & $\begin{array}{r}6,664 \\
(8.8)\end{array}$ & $\begin{array}{r}6,664 \\
(8.8)\end{array}$ \\
\hline Md. & $\begin{array}{r}126,956 \\
(65)\end{array}$ & $\begin{array}{r}121,513 \\
(62)\end{array}$ & $\begin{array}{r}115,016 \\
(59)\end{array}$ & $\begin{array}{r}111,259 \\
(57)\end{array}$ & $\begin{array}{r}96,928 \\
(49)\end{array}$ & $\begin{array}{r}91.767 \\
(47)\end{array}$ & $\begin{array}{r}3,604 \\
\quad(1.8)\end{array}$ & $\begin{array}{l}3,554 \\
(1.8)\end{array}$ \\
\hline Mass. & $\begin{array}{c}1,275,894 \\
(95)\end{array}$ & $\begin{array}{c}1,264,954 \\
(94)\end{array}$ & $\begin{array}{c}1,231,636 \\
(91)\end{array}$ & $\begin{array}{c}1,197,236 \\
(89)\end{array}$ & $\begin{array}{r}781,876 \\
(58)\end{array}$ & $\begin{array}{r}690,471 \\
(51)\end{array}$ & $\begin{array}{r}193,563 \\
(17)\end{array}$ & $\begin{array}{r}116,863 \\
(13)\end{array}$ \\
\hline N.H. & $\begin{array}{r}83,597 \\
(79)\end{array}$ & $\begin{array}{r}74.757 \\
(70)\end{array}$ & $\begin{array}{r}58,611 \\
(55)\end{array}$ & $\begin{array}{r}54,804 \\
(52)\end{array}$ & $\begin{array}{r}60,522 \\
(57)\end{array}$ & $\begin{array}{r}55,439 \\
(52)\end{array}$ & $\begin{array}{r}19.337 \\
(18)\end{array}$ & $\begin{array}{r}15,931 \\
(15)\end{array}$ \\
\hline N.J. & $\begin{array}{c}1,733,794 \\
(96)\end{array}$ & $\begin{array}{c}1,706,154 \\
(94)\end{array}$ & $\begin{array}{c}1,719,035 \\
(95)\end{array}$ & $\begin{array}{c}1,659.519 \\
(92)\end{array}$ & $\begin{array}{c}1,476.752 \\
(82)\end{array}$ & $\begin{array}{c}1.353 .682 \\
(75)\end{array}$ & $\begin{array}{r}954,736 \\
(75)\end{array}$ & $\begin{array}{r}860.152 \\
(68)\end{array}$ \\
\hline N.Y. & $\begin{array}{c}1.744,068 \\
(94)\end{array}$ & $\begin{array}{c}1,718,305 \\
(93)\end{array}$ & $\begin{array}{c}1,720,121 \\
(96)\end{array}$ & $\begin{array}{c}1,644,266 \\
(92)\end{array}$ & $\begin{array}{c}1,163,372 \\
(63)\end{array}$ & $\begin{array}{c}1,040,613 \\
(56)\end{array}$ & $\begin{array}{r}515,943 \\
(35)\end{array}$ & $\begin{array}{r}479,743 \\
(34)\end{array}$ \\
\hline $\mathrm{Pa}$. & $\begin{array}{c}1,355,278 \\
(86)\end{array}$ & $\begin{array}{c}1,327,794 \\
(85)\end{array}$ & $\begin{array}{c}1,262,409 \\
\left(99^{1}\right)\end{array}$ & $\begin{array}{c}1,257,809 \\
\left(99^{1}\right)\end{array}$ & $\begin{array}{r}635,130 \\
(41)\end{array}$ & $\begin{array}{r}306,580 \\
(20)\end{array}$ & - & - \\
\hline R.I. & $\begin{array}{r}350,206 \\
(94)\end{array}$ & $\begin{array}{r}346,906 \\
(93)\end{array}$ & $\begin{array}{r}308,079 \\
(83)\end{array}$ & $\begin{array}{r}308,079 \\
(83)\end{array}$ & $\begin{array}{r}330,297 \\
(89)\end{array}$ & $\begin{array}{r}276,997 \\
(74)\end{array}$ & $\begin{array}{r}191,970 \\
(52)\end{array}$ & $\begin{array}{r}191,970 \\
(52)\end{array}$ \\
\hline Vt. & $\begin{array}{r}74,430 \\
(78)\end{array}$ & $\begin{array}{r}64,309 \\
(67)\end{array}$ & $\begin{array}{r}65,523 \\
(68)\end{array}$ & $\begin{array}{r}56,409 \\
(59)\end{array}$ & $\begin{array}{r}53,236 \\
(55)\end{array}$ & $\begin{array}{r}23,974 \\
(25)\end{array}$ & $\begin{array}{l}2,242 \\
\quad(2.6)\end{array}$ & $\begin{array}{l}2,242 \\
\quad(2.7)\end{array}$ \\
\hline Va. & $\begin{array}{r}963,310 \\
(94)\end{array}$ & $\begin{array}{r}958,589 \\
(93)\end{array}$ & $\begin{array}{r}957,052 \\
(93)\end{array}$ & $\begin{array}{r}952,127 \\
(93)\end{array}$ & $\begin{array}{r}30.865 \\
(3.0)\end{array}$ & $\begin{array}{r}26.130 \\
(2.5)\end{array}$ & $\begin{array}{r}4,098 \\
(0.4)\end{array}$ & $\begin{array}{r}4,038 \\
(0.4)\end{array}$ \\
\hline Total & $\begin{array}{c}8,841,594 \\
(92)\end{array}$ & $\begin{array}{c}8,712.498 \\
(90)\end{array}$ & $\begin{array}{c}8,556,959 \\
(92)\end{array}$ & $\begin{array}{c}8,356,865 \\
(90)\end{array}$ & $\begin{array}{c}5,271,169 \\
(55)\end{array}$ & $\begin{array}{c}4,506,124 \\
(47)\end{array}$ & $\begin{array}{c}2,265,596 \\
(34)\end{array}$ & $\begin{array}{c}2,014,721 \\
(32)\end{array}$ \\
\hline
\end{tabular}

${ }^{1}$ Not representative because value is based on data for only 12 percent ( 55 of 443 ) of randomly selected CWSs and biased to large and very large systems ( 38 of 55 CWSs with THM data). 


\section{Estimated Population Served by All CWSs}

The statistical design and representativeness of the random sample of CWSs inventoried for this study allows projections to be made of the total number of CWSs and the total number of people served by all CWSs in the 12-State area that may have been similarly exposed to VOCs. Two methods of projecting the findings from the random sample have been evaluated to provide a range of estimates on the total number of people who may have been exposed to VOCs in their drinking water. The first method extrapolates the overall detection frequencies for any compound or group of compounds to the total number of CWSs and the population served by them in the 12-State area. The second method extrapolates detection frequencies on a State-by-State basis, aggregating these projections for a regional estimate.

Estimates of the total number of CWSs and the number of people served in the study area that may have been exposed on the basis of simple extrapolation of the detection frequencies for any VOC, THMs, nonTHM VOCs, and MTBE from the random data are shown in table 21 . This method estimates that about 4,700 CWSs serving nearly 54 million people in the region may have had VOCs (or specifically a THM) in their drinking water, and about $930 \mathrm{CWSs}$ and almost 20 million people may have had MTBE in their drinking water. Even at the higher $1.0-\mu \mathrm{g} / \mathrm{L}$ threshold, estimates of the number of CWSs and people that may have had VOCs in their drinking water are substantially similar-4,000 CWSs and 52.8 million people with VOCs, and $820 \mathrm{CWSs}$ and 18.7 million people with MTBE.

In a second method used to estimate the total number of CWSs and the number of people served by these systems in the 12-State area that may have had detections of VOCs during 1993-98, detection frequencies were extrapolated on a State-by-State basis. A State-by-State projection is less likely to overestimate or underestimate the number of systems and population potentially exposed to VOCs in any given State because it does not rely on an average detection frequency for all 12 States. Data on the frequency of detection for the randomly selected CWSs in each State are used to make projections to the total population of CWSs for that State. The individual State projections were then summed to provide regional projections and these are compared with the values obtained by the simple extrapolation described above. The results of the State-by-State projection of the frequency of detection of any VOC, THMs, non-THM VOCs, an 1 MTBE are shown in table 22 .

The total number of CWSs potentially exposed to any VOC in drinking water obtained from the Stateby-State projection (table 22) generally agrees with the estimate provided by an extrapolation of the overall frequency of VOC detections (table 21). Both methods indicate that about $4.700 \mathrm{CWSs}$ in the region may have experienced at least 1 detection of a VOC during 199398 and that about 4,000 CWSs may have had VOCs at concentrations of $1.0 \mu \mathrm{g} / \mathrm{L}$ or greater. The range in the estimates given in tables 21 and 22 provides a measure of the statistical uncertainty, at the 95-percent confidence level, in the estimated number of CWSs that may have had VOC detections. The wide range in the estimates provided by the State-by-State projection, 4,020 to 5,340 CWSs that may have had any VOC detections, probably overstates the uncertainty surrounding the projection. The actual number of systems expesed to a VOC would equal 4,020 only if the lower limit of the 95-percent confidence level for each State's projection were the true value all of the time. The probability of that event is very small.

The projected number of CWSs in the 12-State area that may have had a THM detection is 4,300 to 4,700 at any reporting level and 3,700 to 4,000 at the $1.0-\mu \mathrm{g} / \mathrm{L}$ reporting level. Differences in the number of CWSs projected to have had THM detections vary somewhat between tables 21 and 22 as two different approaches were used to adjust the projection" to correct for the effects of the limited population of randomly selected CWSs with THM data. Data on THMs in drinking water were missing for 32 percent (174 of 538) of the randomly selected CWSs in New York and 88 percent ( 388 of 443 ) of the systems in Pennsylvania. The random sample was under represented, in particular, for small, ground-water supplied systems that characteristically have lower THM detection frequencies. Without adjustments, the projected number of CWSs in the study area that may have had THM detections would exceed the total number of CWSs with VOC detections. Table 21 estimated the number of CWSs that may have had THMs as equal to the number of CWSs with VOC detections, whereas table 22 applied the average frequency of detection of THMs for the 10 States with complete THM data to the States of New York and Pennsylvania. However, to the extent that the frequency of THM detections may be under reported by the missing data, the frequency of VOC detections also may reflect the same. 
When detections of THMs are removed from consideration, the projected number of CWSs in the study area that may have had other VOC detections is cut in half, to about 2,500 CWSs that may have detected non-THM VOCs at any reporting level during the 6 -year period studied. At the $1.0-\mu \mathrm{g} / \mathrm{L}$ reporting level, non-THM VOCs may have occurred in drinking water from about 1,800 to $1,900 \mathrm{CWSs}$ (tables 21 and 22).

The estimated number of CWSs in the 12-State area that may have had detections of MTBE at any reporting level during 1993-98 is approximately 930 to 970 systems and 820 to $890 \mathrm{CWSs}$ at the $1.0-\mu \mathrm{g} / \mathrm{L}$ level when the estimates are extended to Delaware and Pennsylvania, the two States without MTBE data. In table 22, MTBE estimates for Delaware and Pennsylvania were made by applying the average frequency of MTBE detections in the 10 other States, without consideration of the distribution of randomly selected CWSs in respect to OXY/RFG-fuel use and urban areas in each State. To address the uncertainty regarding the accuracy of the estimates for Delaware and Pennsylvania, confidence intervals of 100 percent of the estimated total number of CWSs for these States were incorporated into the projection. The number of CWSs with MTBE concentrations of 5.0 and $20.0 \mu \mathrm{g} / \mathrm{L}$ can be similarly projected as approximately 180 and 80 , respectively.

Because it is impossible to project exactly which systems may have been exposed, projections of population potentially exposed can only be based on the percentage of population served by the randomly selected CWSs in each State that had reported detections of VOCs. The total number of people served by CWSs that were potentially exposed to VOCs (including THMs) at any concentration during this period were about 52.5 to 53.6 million people (tables 21 and 23). Nearly as many people -51.7 to 52.8 million-may have been exposed to VOCs at concentrations at or above $1.0 \mu \mathrm{g} / \mathrm{L}$. About 31.1 or 32 million people in the region may have been exposed to one or more non-THM VOC in their drinking water during 1993-98, and from 18.6 to 19.8 million people may have been provided drinking water at some time during the 6-year period with detectable concentrations of MTBE. At the 1.0- $\mu \mathrm{g} / \mathrm{L}$ reporting level, the estimates total 26.5 to 27.4 million people who may have been exposed to non-THM VOCs and 17.1 to 18.7 million who may have had MTBE at comparat:'e levels in their drinking water.

Certain characteristics of the data assembled for the randomly selected CWSs, however, may confound a simple regional projection of the overall frequency of detection of VOCs. First, the random data are not comprehensive of all VOC analyses for all 2,110 randomly selected CWSs for the 6-year period. and it is likely that other VOC detections have occurre 1 in analyses of drinking-water samples that were not included in these data. To the extent that some analytical data may be missing from this analysis and that data may contain uncounted VOC detections, the detection frequencies, and consequently projections of human exposure, made in this report are negatively biased and conservative. Conversely, if data exist for $\mathrm{CW}^{\prime} \mathrm{S}$ s that currently have no data for specific VOCs in th is analysis, for example the $916 \mathrm{CWSs}$ that are missing any MTBE data, and no additional detections were observed in those data, then the detection frec 'iencies and exposure projections made in this report are positively biased. Also, with regard to the estimates that were made for VOC detections at any reporting level, it is important to recognize that the reporting levels vary from State-to-State or even within some states for selected compounds. The frequency of detection determined for the randomly selected CWSs by co'unting detections at any reporting level is not statistically robust in that the data were not censored to a common reporting level. 
Table 21. Estimated number of community water systems and population in the study area that may have had dete:table concentrations of volatile organic compounds in drinking water during 1993-98 based on extrapolation from randomly selected community water systems

[Estimate values are based on 10,479 active systems serving 58,449.923 people in the 12-State area reported in U.S. Environmental Protection Agency Safe Drinking Water Information System database as of December 1, 1997: estimated values are rounded. CWSs, community water systems]

\begin{tabular}{|c|c|c|c|c|}
\hline $\begin{array}{l}\text { Volatile organic compound } \\
\text { category and reporting level }\end{array}$ & $\begin{array}{c}\text { Detection } \\
\text { frequency for } \\
\text { randomly selected } \\
\text { CWSs } \pm 95 \text {-percent } \\
\text { confidence limits } \\
\text { (percent) }\end{array}$ & $\begin{array}{l}\text { Estimated number } \\
\text { and range in } \\
\text { number of CWSs } \\
\text { that may have had } \\
\text { detections }\end{array}$ & $\begin{array}{l}\text { Percentage of } \\
\text { population } \\
\text { served by } \\
\text { random CWSs } \\
\text { with detections }\end{array}$ & $\begin{array}{c}\text { Estimated } \\
\text { population served by } \\
\text { CWSs that may have } \\
\text { had detections }\end{array}$ \\
\hline $\begin{array}{l}\text { Any volatile organic compound at } \\
\text { any reporting level }\end{array}$ & $\begin{array}{l}45 \\
\pm 2.1\end{array}$ & $\begin{array}{c}4,700 \\
4,500-4,900\end{array}$ & 92 & $53,600,0 า 0$ \\
\hline $\begin{array}{l}\text { Any volatile organic compound at } \\
\text { or above } 1.0 \mu \mathrm{g} / \mathrm{L}\end{array}$ & $\begin{array}{l}38 \\
\pm 2.0\end{array}$ & $\begin{array}{c}4,000 \\
3,800-4,200\end{array}$ & 90 & $52,800,000$ \\
\hline $\begin{array}{l}\text { Trihalomethanes at any reporting } \\
\text { level }\end{array}$ & $\begin{array}{l}{ }^{1} 45 \\
\pm 2.5\end{array}$ & $\begin{array}{c}4,700 \\
4,500-5,000\end{array}$ & 92 & $53,600, c^{n} 0$ \\
\hline $\begin{array}{l}\text { Trihalomethanes at or above } \\
1.0 \mu \mathrm{g} / \mathrm{L}\end{array}$ & $\begin{array}{l}{ }^{1} 38 \\
\pm 2.0\end{array}$ & $\begin{array}{l}4,000 \\
3,800-4,200\end{array}$ & 90 & $52,600,000$ \\
\hline $\begin{array}{l}\text { Non-trihalomethane volatile organic } \\
\text { compounds at any reporting level }\end{array}$ & $\begin{array}{l}24 \\
\pm 1.8\end{array}$ & $\begin{array}{c}2,500 \\
2,300-2,700\end{array}$ & 55 & $32,000,000$ \\
\hline $\begin{array}{l}\text { Non-trihalomethane volatile organic } \\
\text { compounds at or above } 1.0 \mu \mathrm{g} / \mathrm{L}\end{array}$ & $\begin{array}{l}18 \\
\pm 1.9\end{array}$ & $\begin{array}{c}1,900 \\
1,700-2,100\end{array}$ & 47 & $27,400,000$ \\
\hline $\begin{array}{l}\text { Methyl tert-butyl ether at any } \\
\text { reporting level }\end{array}$ & $\begin{array}{r}8.9 \\
\pm 1.6\end{array}$ & $\begin{array}{l}{ }^{2} 930 \\
760-1,100\end{array}$ & 34 & ${ }^{2} 19,800,000$ \\
\hline $\begin{array}{l}\text { Methyl tert-butyl ether at or above } \\
1.0 \mu \mathrm{g} / \mathrm{L}\end{array}$ & $\begin{array}{r}7.8 \\
\pm 1.5\end{array}$ & $\begin{array}{l}2820 \\
660-970\end{array}$ & 32 & ${ }^{2} 18,700,000$ \\
\hline
\end{tabular}

\footnotetext{
${ }^{1}$ Value used equals percentage of systems reporting detections of any volatile organic compound due to incomplete data for trihalomethrnes from New York and Pennsylvania.

Includes Delaware and Pennsylvania.
} 
Table 22. Estimated number of community water systems in the study area that may have had detectable concentrations of volatile organic compounds in drinking water during 1993-98 based on extrapolation of frequency of detection for each State

[All values are rounded. CWSs, coinmunity water systems; VOC, volatile organic compound: THMs, trihalomethanes; MTBE, methyl tert-butyl ether]

\begin{tabular}{|c|c|c|c|c|c|c|c|c|}
\hline \multirow{3}{*}{ State } & \multicolumn{8}{|c|}{ Estimated number and range in number of CWSs that may have had detectable concentrations } \\
\hline & \multicolumn{2}{|c|}{ Any VOC } & \multicolumn{2}{|c|}{ THMs } & \multicolumn{2}{|c|}{ Non-THM VOCs } & \multicolumn{2}{|c|}{ MTBF: } \\
\hline & $\begin{array}{l}\text { At any } \\
\text { reporting } \\
\text { level }\end{array}$ & $\begin{array}{c}\text { At or } \\
\text { above } \\
1.0 \mu \mathrm{g} / \mathrm{L}\end{array}$ & $\begin{array}{c}\text { At any } \\
\text { reporting } \\
\text { level }\end{array}$ & $\begin{array}{c}\text { At or } \\
\text { above } \\
1.0 \mu \mathrm{g} / \mathrm{L}\end{array}$ & $\begin{array}{c}\text { At any } \\
\text { reporting } \\
\text { level }\end{array}$ & $\begin{array}{c}\text { At or } \\
\text { above } \\
1.0 \mu \mathrm{g} / \mathrm{L}\end{array}$ & $\begin{array}{c}\text { At any } \\
\text { reporting } \\
\text { level }\end{array}$ & $\begin{array}{c}\text { At or } \\
\text { above } \\
1.0 \mu \mathrm{g} / \mathrm{L}\end{array}$ \\
\hline Conn. & $\begin{array}{c}220 \\
170-270\end{array}$ & $\begin{array}{c}210 \\
160-260\end{array}$ & $\begin{array}{c}140 \\
90-190\end{array}$ & $\begin{array}{c}120 \\
80-160\end{array}$ & $\begin{array}{c}160 \\
110-210\end{array}$ & $\begin{array}{c}160 \\
110-210\end{array}$ & $\begin{array}{c}70 \\
40-100\end{array}$ & $\begin{array}{c}90 \\
60-120\end{array}$ \\
\hline Del. & $\begin{array}{c}100 \\
70-130\end{array}$ & $\begin{array}{c}70 \\
40-100\end{array}$ & $\begin{array}{c}100 \\
60-140\end{array}$ & $\begin{array}{c}70 \\
40-100\end{array}$ & $\begin{array}{c}50 \\
20-80\end{array}$ & $\begin{array}{c}40 \\
10-70\end{array}$ & $\begin{array}{c}1_{20} \\
0-40\end{array}$ & $\begin{array}{c}120 \\
0-40\end{array}$ \\
\hline Maine & $\begin{array}{c}110 \\
70-150\end{array}$ & $\begin{array}{c}100 \\
60-140\end{array}$ & $\begin{array}{c}30 \\
10-50\end{array}$ & $\begin{array}{c}30 \\
10-50\end{array}$ & $\begin{array}{c}90 \\
50-130\end{array}$ & $\begin{array}{c}70 \\
40-100\end{array}$ & $\begin{array}{c}40 \\
10-70\end{array}$ & $\begin{array}{c}40 \\
10-70\end{array}$ \\
\hline Md. & $\begin{array}{c}230 \\
180-280\end{array}$ & $\begin{array}{c}200 \\
150-250\end{array}$ & $\begin{array}{c}210 \\
160-260\end{array}$ & $\begin{array}{c}180 \\
130-230\end{array}$ & $\begin{array}{c}100 \\
60-140\end{array}$ & $\begin{array}{c}80 \\
40-120\end{array}$ & $\begin{array}{c}20 \\
0-40\end{array}$ & $\begin{array}{c}10 \\
0-20\end{array}$ \\
\hline Mass. & $\begin{array}{c}340 \\
300-380\end{array}$ & $\begin{array}{c}310 \\
260-360\end{array}$ & $\begin{array}{c}280 \\
220-340\end{array}$ & $\begin{array}{c}240 \\
180-300\end{array}$ & $\begin{array}{c}220 \\
170-270\end{array}$ & $\begin{array}{c}180 \\
140-220\end{array}$ & $\begin{array}{c}60 \\
20-100\end{array}$ & $\begin{array}{c}50 \\
20-80\end{array}$ \\
\hline N.H. & $\begin{array}{c}340 \\
290-390\end{array}$ & $\begin{array}{c}240 \\
190-290\end{array}$ & $\begin{array}{c}170 \\
120-220\end{array}$ & $\begin{array}{c}140 \\
100-180\end{array}$ & $\begin{array}{c}240 \\
190-290\end{array}$ & $\begin{array}{c}160 \\
110-210\end{array}$ & $\begin{array}{c}120 \\
80-160\end{array}$ & $\begin{array}{c}80 \\
40-120\end{array}$ \\
\hline N.J. & $\begin{array}{c}460 \\
410-510\end{array}$ & $\begin{array}{c}420 \\
360-480\end{array}$ & $\begin{array}{c}410 \\
360-460\end{array}$ & $\begin{array}{c}370 \\
310-430\end{array}$ & $\begin{array}{c}260 \\
210-310\end{array}$ & $\begin{array}{c}220 \\
170-270\end{array}$ & $\begin{array}{c}190 \\
120-260\end{array}$ & $\begin{array}{c}130 \\
70-190\end{array}$ \\
\hline N.Y. & $\begin{array}{c}1,370 \\
1,260-1.480\end{array}$ & $\begin{array}{c}1,180 \\
1,070-1.290\end{array}$ & $\begin{array}{c}21,220 \\
1,090-1,350\end{array}$ & $\begin{array}{c}21,060 \\
930-1,190\end{array}$ & $\begin{array}{c}560 \\
470-650\end{array}$ & $\begin{array}{c}360 \\
280-440\end{array}$ & $\begin{array}{c}200 \\
110-290\end{array}$ & $\begin{array}{c}240 \\
140-340\end{array}$ \\
\hline Pa. & $\begin{array}{c}610 \\
520-700\end{array}$ & $\begin{array}{c}490 \\
400-580\end{array}$ & $\begin{array}{c}21,010 \\
720-1,300\end{array}$ & $\begin{array}{c}2880 \\
590-1,170\end{array}$ & $\begin{array}{c}460 \\
380-540\end{array}$ & $\begin{array}{c}320 \\
240-400\end{array}$ & $\begin{array}{c}1_{200} \\
0-400\end{array}$ & $\begin{array}{c}1180 \\
0-360\end{array}$ \\
\hline R.I. & $\begin{array}{c}50 \\
40-60\end{array}$ & $\begin{array}{c}50 \\
30-70\end{array}$ & $\begin{array}{c}40 \\
20-60\end{array}$ & $\begin{array}{c}40 \\
20-60\end{array}$ & $\begin{array}{c}40 \\
20-60\end{array}$ & $\begin{array}{c}30 \\
20-40\end{array}$ & $\begin{array}{c}10 \\
0-20\end{array}$ & $\begin{array}{c}10 \\
0-20\end{array}$ \\
\hline Vt. & $\begin{array}{c}250 \\
200-300\end{array}$ & $\begin{array}{c}160 \\
120-200\end{array}$ & $\begin{array}{c}190 \\
140-240\end{array}$ & $\begin{array}{c}150 \\
110-190\end{array}$ & $\begin{array}{c}140 \\
100-180\end{array}$ & $\begin{array}{c}60 \\
30-90\end{array}$ & $\begin{array}{c}20 \\
0-40\end{array}$ & $\begin{array}{c}20 \\
0-40\end{array}$ \\
\hline $\mathrm{Va}^{3}$ & $\begin{array}{c}590 \\
510-670\end{array}$ & $\begin{array}{c}500 \\
420-580\end{array}$ & $\begin{array}{c}500 \\
420-580\end{array}$ & $\begin{array}{c}420 \\
340-500\end{array}$ & $\begin{array}{c}210 \\
150-270\end{array}$ & $\begin{array}{c}150 \\
100-200\end{array}$ & $\begin{array}{c}20 \\
0-40\end{array}$ & $\begin{array}{c}20 \\
0-40\end{array}$ \\
\hline Total & $\begin{array}{c}4,670 \\
4,020-5,320\end{array}$ & $\begin{array}{c}3,930 \\
3,260-4,600\end{array}$ & $\begin{array}{c}4,300 \\
3,410-5,190\end{array}$ & $\begin{array}{c}3,700 \\
2,840-4,560\end{array}$ & $\begin{array}{c}2,530 \\
1,930-3,130\end{array}$ & $\begin{array}{c}1,830 \\
1,290-2,370\end{array}$ & $\begin{array}{c}970 \\
380-1,560\end{array}$ & $\begin{array}{c}890 \\
340-1,440\end{array}$ \\
\hline
\end{tabular}

${ }^{1}$ Estimates for Delaware and PennsyIvania used average frequency of detection for methyl tert-butyl ether for 10 other States.

${ }^{2}$ Estimates for New York and Pennsylvania used average frequency of detection of trihalomethanes for 10 other States.

${ }^{3}$ Includes District of Columbia. 
Table 23. Estimated number of people served by community water systems in the study area that may have had detectable concentrations of volatile organic compounds in drinking water during 1993-98 based on extrapolation of population served by random systems with detections for each State

[All values are rounded. Estimated number of people served by CWSs that may have had detections extrapolated from percentage of population served by randomly selected CWSs that have reported detections of the specified type of VOCs shown in table 20 and the total number of people served by CVSs in the study area shown in table 4. CWSs, community water systems; VOC, volatile organic compound; THMs, trihaIomethanes; MTBE, methyl tert-butyl ether]

\begin{tabular}{|c|c|c|c|c|c|c|c|c|}
\hline \multirow{3}{*}{ State } & \multicolumn{8}{|c|}{ Estimated number of people served by community water systems that may have had detections } \\
\hline & \multicolumn{2}{|c|}{ Any Voc } & \multicolumn{2}{|c|}{ THMs } & \multicolumn{2}{|c|}{ Non-THM VOCs } & \multicolumn{2}{|c|}{ MTBE } \\
\hline & $\begin{array}{c}\text { At any } \\
\text { reporting } \\
\text { level }\end{array}$ & $\begin{array}{c}\text { At or } \\
\text { above } \\
1.0 \mu \mathrm{g} / \mathrm{L}\end{array}$ & $\begin{array}{l}\text { At any } \\
\text { reporting } \\
\text { level }\end{array}$ & $\begin{array}{c}\text { At or } \\
\text { above } \\
1.0 \mu \mathrm{g} / \mathrm{L}\end{array}$ & $\begin{array}{l}\text { At any } \\
\text { reporting } \\
\text { level }\end{array}$ & $\begin{array}{c}\text { At or } \\
\text { above } \\
1.0 \mu \mathrm{g} / \mathrm{L}\end{array}$ & $\begin{array}{l}\text { At any } \\
\text { reporting } \\
\text { level }\end{array}$ & $\begin{array}{c}\text { At or } \\
\text { above } \\
1.0 \mu \mathrm{g} / \mathrm{L}\end{array}$ \\
\hline Conn. & $2,556,000$ & $2,554,000$ & $2,542,000$ & 2.540 .000 & $1,331,000$ & $1,329,000$ & $1,017,000$ & $1,006,000$ \\
\hline Del. & 541,000 & 528,000 & 541,000 & 528,000 & 523,000 & 521,000 & 230,000 & 217,000 \\
\hline Maine & 230,000 & 227,000 & 184,000 & 184.000 & 52,000 & 43,000 & 52,000 & 52,000 \\
\hline Md. & $2,942,000$ & $2.816,000$ & $2,669,000$ & $2,582,000$ & $2,247,000$ & $2,127,000$ & 84,000 & 82,000 \\
\hline Mass. & $7,400,000$ & $7,337,000$ & $7,144,000$ & $6,944,000$ & $4,535,000$ & $4,005,000$ & $1,352,000$ & $1,022,000$ \\
\hline N.H. & 574,000 & 513,000 & 403,000 & 377,000 & 415,000 & 381,000 & 133,000 & 110,000 \\
\hline N.J. & $7,304,000$ & $7,188,000$ & $7,242,000$ & $6,991,000$ & $5,954,000$ & $5,703,000$ & $5,717,000$ & $5,151,000$ \\
\hline N.Y. & $15,662,000$ & $15,431,000$ & $16,019,000$ & $15,312,000$ & $10,480,000$ & $9,374,000$ & $5,868,000$ & $5,586,000$ \\
\hline $\mathrm{Pa}$. & $9,082,000$ & $8,898,000$ & $10,418,000$ & $10,380,000$ & $4,297,000$ & $2,074,000$ & $3,568,000$ & $2,360,000$ \\
\hline R.I. & 912,000 & 904,000 & 802,000 & 802,000 & 860,000 & 721,000 & 500,000 & 500,000 \\
\hline Vt. & 355,000 & 315,000 & 320,000 & 276,000 & 261,000 & 117,000 & 12,000 & 13,000 \\
\hline Va. ${ }^{1}$ & $4,969,000$ & $4,944,000$ & $4,936,000$ & $4,911,000$ & 159,000 & 135,000 & 21,000 & 21,000 \\
\hline Total & $52,500,000$ & $51,700,000$ & $53,200,000$ & $51,800,000$ & $31,100,000$ & $26,500,000$ & $18,600,000$ & $17,100,000$ \\
\hline
\end{tabular}

${ }^{1}$ Includes District of Columbia. 


\section{SUMMARY AND CONCLUSIONS}

This study determined the occurrence and distribution of methyl tert-butyl ether (MTBE) and other volatile organic compounds (VOCs) in public drinking water of the Northeast and Mid-Atlantic regions of the United States for 1993-98. The Northeast and MidAtlantic regions were selected because they have large populations, extensive urban and industrial development, and widespread use and release of many VOCs. These regions comprise the largest contiguous area, outside of California, where the gasoline additive MTBE is used to meet requirements of the Clean Air Act Amendments of 1990. The study area included the six New England States plus New York, New Jersey, Pennsylvania, Maryland, Delaware, and Virginia.

This assessment was designed to provide information based on a statistically representative sample of 20 percent of the community water systems (CWSs) in the 12 States. A random selection of 2,110 CWSs was made to represent the actual distribution of the 10,479 active CWSs in the region as of December 1, 1997 by State, source of water, and size of system. The resulting distribution of randomly selected CWSs included 1,690 systems supplied exclusively by ground water, 270 supplied exclusively by surface water, and 150 systems that draw on both ground- and surface-water sources. About two-thirds of the randomly selected CWSs are small, serving fewer than 500 people, 20 percent serve 501 to 3,300 people, 13 percent serve 3,301 to 50,000 people, and 1.5 percent (31 CWSs) serve more than 50,000 people. The number of systems selected from within each State reflect the size and population of the 12 States and range from 30 systems in Rhode Island to 538 systems in New York.

Information on chemical analyses, as well as supporting documentation, was requested from each State for the randomly selected CWSs. The data were assembled into a project database, reviewed, documented, and analyzed for information on the frequency of detection and reported concentrations of 84 VOC analytes. The data obtained from the States varied considerably in format, analytical coverage, reporting levels, and period of record. A total of 21,635 chemical analyses for one or more VOC in drinking-water samples collected from January 4, 1993 through December 15, 1998 were compiled for the 2,110 randomly selected CWSs.

Sixty-four of the 84 VOC analytes were detected in at least one drinking-water sample at any reporting level. Forty-one percent of all drinking-water samples $(8,955)$, and 45 percent of the randomly selected CWSs (943), contained detectable concentrations of one or more VOC(s); however, more than half of the 64 VOCs detected in drinking water were found in less than 1 percent of the CWSs. When VOCs were detected in drinking water, the co-occurrence of two or more VOCs was more common than the presence of a single compound.

Thirty-eight percent (795) of CWSs reported detection of one or more of 54 VOCs at or above concentrations of $1.0 \mu \mathrm{g} / \mathrm{L}$; the 54 selected VC .s were those that have been analyzed for in drinking water from more than half $(1,055)$ of the randomly selected CWSs. Most concentrations of VOCs measured in drinking water were low (70 percent of all detections were at or below $10 \mu \mathrm{g} / \mathrm{L}$ ), but 16 VOCs were measured at levels that equaled or exceeded rigulated (Maximum Contaminant Levels (MCLs) or Health Advisories (HAs)) or recommended (Drinking Water Advisory (DWA)) concentrations.

VOC detections in drinking water were significantly related $(\mathrm{p}<0.0001)$ to urban areas with population density at or above 1,000 people per $\mathrm{mi}^{2}$. The probability of detecting VOCs at or above $1 . C \mu \mathrm{g} / \mathrm{L}$ in drinking water was 1.8 times greater for $\mathrm{CW}_{\mathrm{s}} \mathrm{s}$ that have a water source in an urban area compared to those CWSs with no sources in urban areas. Consenuently, the most urbanized States with high populaticn density-New Jersey, Massachusetts, and Rhode Island-have the highest VOC detection freq Iencies. More than two-thirds (83 of 122) of the randomly selected CWSs in New Jersey reported detecting VOCs at or above $1.0 \mu \mathrm{g} / \mathrm{L}$ in their drinking water. VOCs were more frequently detected in drinking water from CWSs supplied by surface water or both ground- and surface-water sources than from CWSs supplied exclusively by ground water, and were more frequently reported by systems that serve large populations than by the smaller systems. These factors are autocorrelated with urban source-water locations.

Four trihalomethane (THM) compounds-chloroform, bromodichloromethane, chlorodibromomethane, and bromoform-chemicals produced as by-products of disinfecting drinking water with chlorine, were the most frequently detected VOCs. One or more of the four THM compounds (as measured by total THMs) was detected in 41 percent of the CWSs. Chloroform was the most frequently detected trihalom- 
ethane in drinking water, measured in 39 percent of the CWSs at any reporting levels and in 33 percent of CWSs at the $1.0-\mu \mathrm{g} / \mathrm{L}$ reporting level. More than 90 percent of CWSs supplied by any surface-water source reported detectable concentrations of one or more THM. The median total THM concentration for surface-water supplied CWSs was $30.3 \mu \mathrm{g} / \mathrm{L}$. Comparatively, only 32 percent of CWSs supplied exclusively by ground-water sources contained THMs and the median total THM concentration for those systems was just $2.5 \mu \mathrm{g} / \mathrm{L}$. Three percent of the CWSs with THM data reported concentrations that equaled or exceeded the $100-\mu \mathrm{g} / \mathrm{L} \mathrm{MCL}$ in some drinking-water samples.

The gasoline additive MTBE was the most frequently detected VOC after the THM compounds. MTBE was reported in 343 drinking-water samples from $106 \mathrm{CWSs}$ at concentrations ranging from 0.2 to $210 \mu \mathrm{g} / \mathrm{L}$. No MTBE data were available for Delaware and Pennsylvania. The overall frequency of detecting MTBE was 8.9 percent (or 1,194 CWSs with data) at any reporting level and 7.8 percent of $1,074 \mathrm{CWSs}$ when the data are censored at the $1.0-\mu \mathrm{g} / \mathrm{L}$ reporting level. Only 0.8 percent of the randomly selected CWSs with MTBE data reported concentrations that equaled or exceeded the $20-\mu \mathrm{g} / \mathrm{L}$ lower limit of the USEPA's DWA for MTBE; 2 percent of the CWSs reported MTBE concentrations at or above the California 5$\mu \mathrm{g} / \mathrm{L}$ taste and odor threshold. The probability of MTBE detections at or above $1.0 \mu \mathrm{g} / \mathrm{L}$ in drinking water was five times more likely $(\mathrm{p}<0.0001)$ to occur in those areas of the Northeast and Mid-Atlantic regions where it is used in substantial amounts under the oxygenated and reformulated fuels program.

Twelve other VOCs associated with gasoline contamination also were reported in drinking water in the 12-State region. Total xylenes and toluene, detected in 3.2 and 2.5 percent of CWSs respectively, were the most frequently detected gasoline components after MTBE. Detection frequencies of the individual gasoline compounds (benzene, toluene, ethylbenzene, and xylenes (BTEX)) do not approach that of MTBE, but collectively these compounds were detected in 8.4 percent of randomly selected CWSs at any reporting level. Although as widely distributed in drinking water in the 12-State area, MTBE and BTEX compounds rarely co-occur. Only 12 drinking-water samples from 9 CWSs contained simultaneous detections of MTBE and a BTEX compound, and in only 3 of the samples were MTBE and BTEX concentrations above $20 \mu \mathrm{g} / \mathrm{L}$. The low MTBE and BTEX concentrations and the lack of significant co-occurrence indicates that most gasoline contaminants in drinking water probably represent a combination of distant point sources (leakirg underground storage tanks), small leaks and spills, or other diffuse nonpoint source rather than nearby pcint sources. The widespread occurrence of MTBE and the lack of a substantial co-occurrence between MTBE and BTEX leads to the conclusion that the extent of contamination of drinking water from gasolire is substantially greater with the use of MTBE than would have occurred had this oxygenate never been added to gasoline.

The use of VOCs as solvents is widespread in industrial, commercial, and residential settings, and consequently, solvents were collectively among the most frequently detected VOCs in drinking water in the $12-$ State area. One or more of 27 individual solvent VOCs were detected at any reporting level in 3,080 drinking-water samples from 304 randomly selected CWSs (14 percent) and in $206 \mathrm{CWSs}$ at or akove concentrations of $1.0 \mu \mathrm{g} / \mathrm{L}$. Three commonly used solvents-1,1,1-trichloroethane, trichloroethylene, and tetrachloroethylene-were each detected in about 5 percent of CWSs. Half of the 3,080 drinking-water samples with solvents contained more than 1 solvent compound. The high degree of co-occurrence among solvents probably reflects common sources (combinations of solvents frequently occur in cleaning chemical formulations) and the widely documented presence of transformation by-products and degradates. The occurrence of solvents in drinking water was significantly associated $(\mathrm{p}<0.0001)$ with high-population-density urban areas. Although most solvent concentrations in drinking water were less than $5.0 \mu \mathrm{g} / \mathrm{L}$, concentrations of eight solvents exceeded MCLs.

Other VOCs were relatively rarely detected in drinking water in the 12-State area. The refrigerant dichlorodifluoromethane was reported in drirking water by 1.2 percent of the randomly selected CWSs and often co-occurred with another refrigerant, fluorotrichloromethane. Two VOCs primarily used as fumigant pesticides - dibromochloropropane and ethylene dibromide - were reported in drinking water $r y$ almost 2 percent of the CWSs and have exceeded their MCLs of 0.2 and $0.05 \mu \mathrm{g} / \mathrm{L}$ in a few samples.

Information on the population served by the randomly selected CWSs that have reported detectable concentrations of VOCs during 1993-98 was tabulated to provide estimates of the total number of systems and 
people potentially exposed to VOCs in drinking water in the 12-State area during this time period. The 2,110 randomly selected CWSs inventoried for this study collectively serve 9.6 million people and about 92 percent of them, or 8.8 million people, get their drinking water from a CWS that has reported at least one detection of a VOC during the 6-year period. Commonly, the potential exposure was to one or more THMs, but more than half of the population served, 5.3 million people, also may have been exposed to a nonTHM VOC in their drinking water during this period. Tabulation of the number of people potentially exposed to MTBE in drinking water from the randomly selected CWSs provides a figure of about 2.3 million people; however, only 1,194 CWSs serving 6.7 million people reported data for MTBE. Projecting the 34 percent of people served by CWSs with MTBE data that were potentially exposed to MTBE for the total 9.6 million served by all randomly selected CWSs indicates that the number of people potentially exposed for the random sample may be as high as 3.3 million people.

Information on the number of people served by randomly selected CWSs that have reported VOC concentrations in drinking water that equaled or exceeded USEPA drinking-water regulations or recommendations also was tabulated. Six percent (127) of the 2,110 randomly selected CWSs reported concentrations of 16 VOCs at or above drinking-water criteria. The 127 CWSs collectively serve 2.6 million people. Thirteen VOCs exceeded MCLs, 2 VOCs exceeded HAs, and MTBE concentrations exceeded the DWA. Most of the MCL exceedances were for total THMs and the solvents trichloroethylene and tetrachloroethylene. Trichloroethylene and tetrachloroethylene concentrations that were more than 100 times greater than the $5.0-\mu \mathrm{g} / \mathrm{L}$ MCLs were reported for multiple samples from a few CWSs.

On the basis of the representative design of this study, the frequencies of detecting any VOC, THMs, non-THM VOCs, and MTBE in drinking water from the randomly selected CWSs were projected to the total population of CWSs in the 12-State area to estimate the total number of CWSs in the region that may lave had VOC detections during 1993-98. Estimates made by projecting the overall detection frequency for the 12 States, as well as for each State individually, were made and compared. These methods project that about 4,700 CWSs $(4,000 \mathrm{CWSs}$ at the $1.0-\mu \mathrm{g} / \mathrm{L}$ reporting level) in the region may have experienced a VOC contaminant in their drinking water and that most often it was a THM. About $2,500 \mathrm{CWSs}(1,800$ to $1,900 \mathrm{CWS}$ at the $1.0-\mu \mathrm{g} / \mathrm{L}$ reporting level) may have detected a nonTHM VOC at least once during the 6-year period, and approximately 930 to 970 CWSs ( 820 to 890 CWSs at the $1.0-\mu \mathrm{g} / \mathrm{L}$ reporting level) may have had MTBE present in their drinking water.

Projecting the total number of people served by CWSs in the 12-State area that may have been exposed to VOCs during 1993-98 has even greater unc rtainty than projecting the number of systems because it is impossible to predict which specific systems ray have had detections. Estimates of the population potentially exposed were made by extrapolating the percentage of people served by the randomly selected CWSs with VOC detections. This method provides estimates of approximately 52.5 to 53.6 million people ( 51.7 to 52.8 million people at the $1.0-\mu \mathrm{g} / \mathrm{L}$ reporting level) in the 12-State area, or that nearly the entire populatic $n$ of the region served by CWSs potentially may have 1 -en exposed at least once to a VOC in their drinking water during 1993-98. It is most likely that the exposure would have been to a THM disinfectant by-protuct. In addition, 31.1 to 32 million people ( 26.5 to 27.4 million people at the $1.0-\mu \mathrm{g} / \mathrm{L}$ reporting level) may have been exposed to a non-THM VOC, and from 18.6 to 19.8 million people (17.1 to 18.7 million people at the 1.0 $\mu \mathrm{g} / \mathrm{L}$ reporting level) may have been exposed to MTBE at least once in their drinking water during 19ऽ3-98. 


\section{REFERENCES CITED}

Alliance for Proper Gasoline Handling, 1999, New alliance launches consumer gas care campaign to prevent small gasoline spills: Washington, D.C., The Alliance for Proper Gasoline Handling, 2 p. (press release, July 27, 1999, accessed December 3, 1999 at URL http:// www.gas-care.org/Press_release.htm)

Ashford, N.A., and Miller, C.S., 1998, Chemical exposures-Low levels and high stakes (2nd ed.): New York, Wiley \& Sons, $464 \mathrm{p}$.

Baehr, A.L., Stackelberg. P.E., and Baker, R.J., 1999, Evaluation of the atmosphere as a source of volatile organic compounds in shallow groundwater: Water Resources Research, v. 35, no. 1, p. 127-136.

Baehr, A.L., and Zapecza, O.S., 1998, Methyl tert-butyl ether (MTBE) and other volatile organic compounds in lakes in Byram Township, Sussex County, New Jersey: U.S. Geological Survey Water-Resources Investigations Report 98-4264, 8 p.

Bellar, T.A., Lichtenberg, J.J., and Kroner, R.C., 1974, The occurrence of organohalides in chlorinated drinking waters: Journal of the American Water Works Association, v. 66 , no. 12 , p. 703-706.

Bender, D.A., Zogorski, J.S., Halde, M.J., and Rowe, B.L., 1999 , Selection procedure and salient information for volatile organic compounds emphasized in the National Water-Quality Assessment Program: U.S. Geological Survey Open-File Report 99-182, 32 p.

California Department of Health Services, 1999. Final statement of reasons, secondary maximum contaminant level for methyl tert-butyl ether and revisions to the unregulated chemical monitoring list, Title 22, California Code of Regulations: California Department of Health Services, accessed May 15, 2000 at URL http://www.dhs.cahwnet.gov./ps/ddwem/chemicals/ MTBE/mtbeindex.htm.

DeLorme, 1999, Street Atlas USA: http://www. delorme.com.

Delzer, G.C., Zogorski, J.S., Lopes, T.J., and Bosshart, R.L., 1996 , Occurrence of the gasoline oxygenate MTBE and BTEX compounds in urban stormwater in the United States, 1991-95: U.S. Geological Survey WaterResources Investigations Report 96-4145, 6 p.

Gilliom, R.J., Alley, W.M., and Gurtz, M.E., 1995, Design of the National Water-Quality Assessment Program-Occurrence and distribution of water-quality conditions: U.S. Geological Survey Circular 1112, $33 \mathrm{p}$.

Grady, S.J., 1997a, Distribution of MTBE in ground water in New England by aquifer type and land use [abs.], in American Chemical Society Division of Environmental Chemistry Preprints of Extended Abstracts, 213th National meeting, San Francisco, Calif., April 13-17: American Chemical Society, v. 37, no. 1, p. 392-394. 1997b, Volatile organic compounds in gro"nd water in the Connecticut, Housatonic, and Thames River Basins, 1993-95: U.S. Geological Survey Frct Sheet FS-029-97, 6 p.

Grady, S.J., and Casey, G.D., 1999, A plan for assessing the occurrence and distribution of methyl tert-butyl ether and other volatile organic compounds in drinl ing water and ambient ground water in the Northeast and MidAtlantic regions of the United States: U.S. Geological Survey Open-File Report 99-207, 36 p.

Grady, S.J., and Mullaney, J.R., 1998, Natural and human factors affecting shallow water quality in surficial aquifers in the Connecticut, Housatonic, and Thames River Basins: U.S. Geological Survey Water-Resources Investigations Report 98-4042, $81 \mathrm{p}$.

Hanchar, D.W., and Grady, S.J., 1994, Effects of urban land use on shallow ground-water quality in stratified-drift aquifers - Comparison of data from the Hud on River basin, New York and the Connecticut River basin, Connecticut and Massachusetts [abs.], in EOS Transactions, 1994 Spring meeting, Baltimore, Md., May 23-27, 1994: Washington D.C., American Geophysical Union, v. 75, no. 16, p. 150.

Helsel, D.R., and Hirsch, R.M., 1992, Statistical methods in water resources: New York, Elsevier Scienc?, 522 p.

Hitzig, R., Kostecki, P., and Leonard, D., 1998, Study reports LUST programs are feeling effects of MTBE releases: Soil \& Groundwater Cleanup, Aug/Sept. 1909, p. 15-19.

Hunter, Bruce, 1999, Impacts of small gasoline sFills on ground water [abs.], in MTBE \& other toxics in Maine's environment, 1999 Maine Water Conference, presentation, April 15, 1999: Augusta, Maine, Maine Department of Environmental Protection.

Johnson, R.L., Pankow, J.F, Bender, D.A., Price, C.V., and Zogorski, J.S., 2000, MTBE-To what exten+ will past releases contaminate community water supp.y wells: Environmental Science \& Technology, v. 34, no. 9, p. 2A-9A.

King, W.D., and Marrett, L.D., 1996, Case contro! study of water source and bladder cancer: Cancer Causes and Control, v. 7, p. 596-604.

Klotz, J.B., and Pyrch, L.A., 1999, Neural tube defects and drinking water disinfection by-products: Epid ‘miology, v. 10, p. $383-390$.

Lapham, W.W., and Tadayon, Saeid, 1996, Plan for assessment of the occurrence, status, and distribution of volatile organic compounds in aquifers of the United States: U.S. Geological Survey Open-File Report 96-199, 44 p.

Lince, D.P, Wilson, L.R., and Carlson, G.A., 1998, Methyl tert-butyl ether (MTBE) contamination in private wells near gasoline stations in upstate New York: Pulletin of Environmental Contaminant Toxicology, v. 61 , p. 484-488. 
Lindsey, B.D., Breen, K.J., and Daly, M.H., 1997, MTBE in water from fractured-bedrock aquifers, south-central Pennsylvania [abs.], in American Chemical Society Division of Environmental Chemistry Preprints of Extended Abstracts, 213th National meeting, San Francisco, Calif., April 13-17: American Chemical Society, v. 37, no. 1, p. 399-400.

Mackay, D.M., and Smith, L.A., 1993, Organic contaminants, in Alley, W. M., ed., Regional ground-water quality: New York, Van Nostrand Reinhold, p. 323-343.

Malcolm Pirnie, Inc., 1998, Taste and odor properties of methyl tertiary-butyl ether and implications for setting a secondary maximum contaminant level: Oakland, Calif., Malcolm Pirnie, Inc., Technical Memorandum, June 26, 1998, prepared for the Oxygenated Fuels Association, Inc., variously paginated.

Moran, M.J., Zogorski, J.S., and Squillace, P.J., 1999. MTBE in ground water of the United States-Occurrence, potential sources, and long-range transport, in Water Resources Conference, American Water Works Association, Norfolk, Va., September 26-29, 1999 [Proceedings]: Denver, Colo., American Water Works Association [CD-Rom disk].

Morris, R.D., Audet, A.M., and Angelillo, I.F., 1992, Chlorination, chlorination by-products, and cancer-A meta-analysis: American Journal of Public Health, v. 82, no. 7. p. 955-963.

Mullaney, J.R., and Grady, S.J., 1997, Hydrogeology and water quality of a surficial aquifer underlying an urban area, Manchester, Connecticut: U.S. Geological Survey Water-Resources Investigations Report 97-4195, 40 p.

NESCAUM, 1999, RFG/MTBE findings \& recommendations, August 1999: Boston, Mass., Northeast States for Coordinated Air Use Management, accessed December 1, 1999 at URL http://www.nescaum.org/RFG/ RFGPh2.shtml.

Office of Science and Technology Policy, 1997, Interagency assessment of oxygenated fuels: Washington, D.C., Office of Science and Technology Policy, National Science and Technology Council, Executive Office of the President of the United States, $239 \mathrm{p}$.

Pankow, J.F., Thomson, N.R., Johnson, R.L., Baehr, A.L., and Zogorski, J.S., 1997. The urban atmosphere as a non-point source for the transport of MTBE and other volatile organic compounds (VOCs) to shallow ground water: Environmental Science \& Technology, v. 31, no. 10, p. $2821-2828$.

Pomes, M.L., Green, W.R., Thurman, E.M., Orem, W.H., and Lerch, H.E., 1999, DBP formation potential of aquatic humic substances: Journal of the American Water Works Association, v. 91, no. 3, p. 103-115.

Price, C.V., and Clawges, R.M., 1999, Digital data sets describing water use, toxic chemical releases, metropolitan areas, and population density of the conterminous United States: U.S. Geological Survey Open-File Report 99-78, scale 1:2,000,000 [CD-ROM disk].
Robbins, G.A., Henebry, B.J., Schmitt, B.M., Bartolomeo, F.B., Green, A., and Zack, P., 1999, Evidence for MTBE in heating oil: Ground Water Monitoring Review, v. 19, no. 2, p. 65-69.

Sakata, R.Y., and Osinski, M.T., 1999, MTBE and the Safe Drinking Water Act-Regulatory and policy considerations [abs.], in EOS Transactions, 1999 Fall meeting, San Francisco, Calif., December 13-17, 1999: Washington, D.C., American Geophysical Union, v.80, no. 46, November 16, 1999 Supplement, p. F422.

Solley, W.B., Pierce, R.R., and Perlman, H.A., 1998, Estimated use of water in the United States in 1935: U.S. Geological Survey Circular 1200, 71 p.

Squillace, P.J., 1999, Occurrence of MTBE in ground water of the United States, 1993-98, and logistic regression analysis of explanatory factors [abs.], in EOS Transactions, 1999 Fall meeting, San Francisco, Calif., December 13-17, 1999: Washington, D.C., f merican Geophysical Union, v. 80, no. 46, November 16, 1999 Supplement, p. F420.

Squillace, P.J., Moran, M.J., Lapham, W. W., Price, C.V., Clawges, R. M., and Zogorski, J.S., 1999, Volatile organic compounds in untreated ambient grorndwater of the United States, 1985-1995: Environmental Science \& Technology, v. 33, p. 4176-4187.

Squillace, P.J., Zogorski, J.S., Wilber, W.G., and Price, C.V., 1996, Preliminary assessment of the occurrence and possible sources of MTBE in groundwater in the United States, 1993-1994: Environmental Science \&: Technology, v. 30, no. 5, p. 1712-1730.

Stackelberg, P.E., O'Brien, A.K., and Terracciano, S.A., 1997, Occurrence of MTBE in surface and ground water, Long Island, N.Y., and N.J.: American Chemical Society Division of Environmental Chemistry Preprints of Extended Abstracts, 213th National meeting, San Francisco, Calif., April 13-17: American Chemical Society, v. 37, no. 1, p. 394-397.

Stangroom, S.J., Collins, C.D., and Lester, J.N., 1998, Sources of organic micropollutants to lowland rivers: Environmental Technology, v. 19, p. 643-66€.

Staples, C.A., Werner, A.F., and Hoogheem, T.J., 1985, Assessment of priority pollutant concentrations in the United States using STORET database: Environmental Toxicology and Chemistry, v. 4, p. 131-142.

State of Maine, 1998, The presence of MTBE and other gasoline compounds in Maine's drinking water-A preliminary report, October 13, 1998: Augusta, Maine, Maine Dept. of Human Services, Bureau of Health, Maine Dept. of Environmental Protection, Bureau of Waste Management \& Remediation, and Maine Department of Conservation, Geological Survey, $15 \mathrm{p}$. 
Terracciano, S.A., and O'Brien, A.K., 1997, Occurrence of volatile organic compounds in streams on Long Island, New York, and in New Jersey-Overview of available data and reconnaissance sampling: U.S. Geological Survey Fact Sheet FS-063-97, 4 p.

U.S. Department of Commerce, 1993, TIGER/line precensus files, 1990, edition 1.1: U.S. Department of Commerce, Bureau of Census, 1:100,000 digital data, accessed January 25, 1999 at URL http://water.usgs.gov/GIS/ metadata/usgswrd/county 100.html.

U.S. Department of Energy, 1999, Petroleum supply monthly, table D4. Monthly methyl tertiary butyl ether (MTBE) production by merchant and captive plants: U.S. Department of Energy, Energy Information Administration, accessed April 3, 2000 at URL http://www.eia.doe.gov/oil_gas/petroleum/ data_publications/monthly_oxygenate_report/ current/pdf/tabled4.pdf.

U.S. Environmental Protection Agency, 1994, Drinking water glossary-A dictionary of technical and legal terms related to drinking water: Washington, D.C., Office of Water, USEPA 810-B-94-006, 108 p.

-1995 , Consolidated summary of State reporting requirements for the Safe Drinking Water Information System (SDWIS): Washington, D.C., Office of Water, USEPA 812-B-95-001, variously paginated.

1996, Drinking water regulations and health advisories: Washington, D.C., Office of Water, USEPA 822R-96-001, 16 p.

1997, Drinking water advisory-Consumer acceptability advice and health effects analysis on methyl tertiary-butyl ether (MTBE): Washington, D.C., Office of Water, USEPA 822-F-97-009, $34 \mathrm{p}$.

1998a, Oxygenates in water-Critical information and research needs: Washington, D.C.. Office of Research and Development, USEPA 600R-98-048, $65 \mathrm{p}$.

1998b, Announcement of the drinking water contaminant candidate list: Federal Register, March 12, 1998, v. 63 , no. 40 , p. $10273-10287$.

$1998 \mathrm{c}$, List of reformulated gasoline program areas, July 2, 1998: U.S. Environmental Protection Agency, Office of Mobile Sources, accessed January 11, 1999, at URL http://www.epa.gov/oms/rfgarea.htm. 1998d, Table of winter oxygenated fuels program by state, September 28, 1998: U.S. Environmental Protection Agency, Office of Mobile Sources, accessed January 11, 1999 at URL http://www.epa.gov/ oms/fuels.htm.

1998e, National primary drinking water regulations-Disinfectants and disinfection byproducts, final rule: Federal Register, Wednesday, December 16, 1998, v. 63, no. 241, p. 69390-69476.

1999a, Revisions to the unregulated contaminant monitoring regulation for public water systems; proposed rule: Federal Register, April 30, 1998 v. 64, no. 83 , p. $23298-23458$.

1999b, A review of contaminant occurrenc? in public water systems: Washington, D.C., Office of Water, USEPA 816-R-99-006, 78 p.

Waller, K., Swan, S.H., DeLorenze, G., and Hopkins, B., 1998, Trihalomethanes in drinking water and spontaneous abortion: Epidemiology, v. 9, nา. 2, 134-140.

Westrick, J. J., Mello, J.W., and Thomas, R.F., 19`4, The groundwater supply survey: Journal of the f merican Water Works Association, v. 76, no. 5, p. 52-59.

Young, W.F., Horth, H., Crance, R., Ogden, T., and Arnott, M., 1996, Taste and odour threshold concent ations of potential potable water contaminants: Water Research, v. 30, p. 331-340.

Zogorski, J.S., Delzer, GC., Bender, D.A., Squillace, P.J., Lopes, T.J., Baehr, A.L., Stackelberg, P.A., Landmeyer, J.E., Boughton, C.J., Lico, M.S., Pankow, J.F., Johnson, R.L., and Thomson, N.R., 1998, MTBE-Summary of findings and research by the U.S. Geological Survey, in Annual Conference of the American Water V'orks Association-Water quality, Dallas, Tex., June 21-25, 1998 [Proceedings]: Denver, Colo., American Water Works Association, p. 287-309.

Zogorski, J.S., Morduchowitz, Abraham, Baehr, A.L., Bauman, B.J., Conrad, D.L., Drew, R.T., Korte, N.E., Lapham, W.W., Pankow, J.F., and Washingtcn, E.R., 1997, Chapter 2, Fuel oxygenates and water quality, in Interagency assessment of oxygenated fuels: Washington, D.C, Office of Science and Technology Policy, 80 p. (8 app.). 

APPENDIXES 

Appendix 1. Volatile organic compounds included in analyses of drinking water for randomly selected community water systems in the study area, 1993-98

[IUPAC, International Union of Pure and Applied Chemistry; USEPA, U.S. Environmental Protection Agency: CAS, Chemical Abstract Services; r, regulated compound required by Safe Drinking Water Act (SDWA); ur, unregulated compound required by SDWA: sd, unregulated compound required at the discretion of the State; $n$, not required by SDWA: c. included on USEPA's Drinking Water Contaminant Candidate List (U.S. Environmental Prot sction Agency, 1998b)]

\begin{tabular}{|c|c|c|c|c|c|c|}
\hline $\begin{array}{c}\text { Volatile organic } \\
\text { compound } \\
\text { (common or trade name) }\end{array}$ & IUPAC name & $\begin{array}{c}\text { USEPA } \\
\text { contaminant } \\
\text { code }\end{array}$ & $\begin{array}{c}\text { CAS } \\
\text { number }\end{array}$ & Compound class & $\begin{array}{l}\text { Primary use } \\
\text { or source }\end{array}$ & SDWA \\
\hline Acetone & 2-Propanone & 2243 & $67-64-1$ & Ketone & Solvent & $\mathrm{c}$ \\
\hline Acrolein & 2-Propenal & 2238 & $107-02-8$ & Oxy alkene & Organic synthesis & $\mathrm{n}$ \\
\hline Acrylonitrile & 2-Propenenitrile & 2240 & $107-13-1$ & Nitro alkene & Organic synthesis & $\mathrm{n}$ \\
\hline Benzene & Benzene & 2990 & $71-43-2$ & Aromatic hydrocarbon & Gasoline & $\mathrm{r}$ \\
\hline $\begin{array}{l}\text { Bromobenzene } \\
\text { (Phenyl bromide) }\end{array}$ & Bromobenzene & 2993 & $108-86-1$ & Halogenated aromatic & Solvent & ur, c \\
\hline $\begin{array}{l}\text { Bromochloromethane } \\
\text { (Methylene chlorobromide) }\end{array}$ & Bromochloromethane & 2430 & $74-97-5$ & Halogenated alkane & Organic synthesis & sd \\
\hline $\begin{array}{l}\text { Bromodichloromethane } \\
\text { (Dichlorobromomethane) }\end{array}$ & Bromodichloromethane & 2943 & $75-27-4$ & Halogenated alkane & Disinfectant by-product & ur \\
\hline Bromoform & Tribromomethane & 2942 & $75-25-2$ & Halogenated alkane & Disinfectant by-prodect & ur \\
\hline $\begin{array}{l}\text { Bromomethane } \\
\text { (Methyl bromide) }\end{array}$ & Bromomethane & 2214 & $74-83-9$ & Halogenated alkane & Fumigant & ur, c \\
\hline $\begin{array}{l}n \text {-Butylbenzene } \\
\text { (1-Phenylbutane) }\end{array}$ & n-Butylbenzene & 2422 & $104-51-8$ & Alkyl benzene & Hydrocarbon & sd \\
\hline sec-Butylbenzene & (1-Methylpropyl)benzene & 2428 & $135-98-8$ & Alkyl benzene & Hydrocarbon & sd \\
\hline tert-Butylbenzene & (1,1-Dimethylethyl)benzene & 2426 & $98-06-6$ & Alkyl benzene & Hydrocarbon & sd \\
\hline Carbon disulfide & Carbon disulfide & - & $75-15-0$ & Sulfur alkane & Organic synthesis & $\mathrm{n}$ \\
\hline Carbon tetrachloride & Tetrachloromethane & 2982 & $56-23-5$ & Halogenated alkane & Solvent & $\mathbf{r}$ \\
\hline $\begin{array}{l}\text { 1-Chlorobutane } \\
\text { ( } n \text {-Butyl chloride) }\end{array}$ & 1-Chlorobutane & 2086 & $109-69-3$ & Halogenated alkane & Organic synthesis & $\mathrm{n}$ \\
\hline Chlorodibromomethane & Dibromochloromethane & 2944 & $124-48-1$ & Halogenated alkane & Disinfectant by-prodect & ur \\
\hline $\begin{array}{l}\text { Chloroethane } \\
\text { (Ethyl chloride) }\end{array}$ & Chloroethane & 2216 & $75-00-3$ & Halogenated alkane & Solvent & ur \\
\hline 2-Chloroethyl vinyl ether & 2-Chloroethoxyethene & 2234 & $110-75-8$ & Ether & Organic synthesis & $\mathrm{n}$ \\
\hline Chloroform & Trichloromethane & 2941 & $67-66-3$ & Halogenated alkane & Disinfectant by-prodıct & ur \\
\hline $\begin{array}{l}\text { Chloromethane } \\
\text { (Methyl chloride) }\end{array}$ & Chloromethane & 2210 & $74-87-3$ & Halogenated alkane & Refrigerant & ur \\
\hline$o$-Chlorotoluene & 1-Chloro-2-methylbenzene & 2965 & $95-49-8$ & Halogenated aromatic & Solvent & ur \\
\hline$p$-Chlorotoluene & 1-Chloro-4-methylbenzene & 2966 & $106-43-4$ & Halogenated aromatic & Solvent & ur \\
\hline $\begin{array}{l}\text { Dibromochloropropane } \\
\text { (DBCP, Nemagon) }\end{array}$ & 1,2-Dibromo-3-chloropropane & 2931 & $96-12-8$ & Halogenated alkane & Fumigant & $\mathrm{r}$ \\
\hline $\begin{array}{l}\text { Dibromomethane } \\
\text { (Methylene dibromide) }\end{array}$ & Dibromomethane & 2408 & $74-95-3$ & HaIogenated alkane & Solvent & ur \\
\hline m-Dichlorobenzene & 1,3-Dichlorobenzene & 2967 & $541-73-1$ & Halogenated aromatic & Solvent & ur \\
\hline$a$-Dichlorobenzene & 1.2-Dichlorobenzene & 2968 & $95-50-1$ & Halogenated aromatic & Solvent & $\mathbf{r}$ \\
\hline$p$-Dichlorobenzene & 1,4-Dichlorobenzene & 2969 & $106-46-7$ & Halogenated aromatic & Fumigant & $\mathbf{r}$ \\
\hline Dichlorobenzenes, total & $\begin{array}{l}\text { Dichlorobenzenes, (mixed iso- } \\
\text { mers) }\end{array}$ & 2401 & $25321-22-6$ & Halogenated aromatic & Solvents & $\mathrm{n}$ \\
\hline $\begin{array}{l}\text { Dichlorodifluoromethane } \\
\text { (CFC 12; Freon 12) }\end{array}$ & Dichlorodifluoromethane & 2212 & $75-71-8$ & Halogenated alkane & Refrigerant & sd \\
\hline $\begin{array}{l}\text { 1,1-Dichloroethane } \\
\text { (Ethylidene chloride) }\end{array}$ & 1,1-Dichloroethane & 2978 & $75-34-3$ & Halogenated alkane & Solvent & ur, c \\
\hline $\begin{array}{l}\text { 1,2-Dichloroethane } \\
\text { (Ethylene dichloride) }\end{array}$ & 1.2-Dichloroethane & 2980 & $107-06-2$ & Halogenated alkane & Solvent & $\mathbf{r}$ \\
\hline $\begin{array}{l}\text { 1.1-Dichloroethene } \\
\text { (Vinylidene chloride) }\end{array}$ & 1,1-Dichloroethene & 2977 & $75-35-4$ & Halogenated alkene & Solvent & $\mathbf{r}$ \\
\hline cis-1,2-Dichloroethene & cis-1,2-Dichloroethene & 2380 & $156-59-2$ & Halogenated alkene & Solvent & $\mathbf{r}$ \\
\hline
\end{tabular}


Appendix 1. Volatile organic compounds included in analyses of drinking water for randomly selected community water systems in the study area,1993-98-Continued

[IUPAC, International Union of Pure and Applied Chemistry; USEPA, U.S. Environmental Protection Agency; CAS, Chemical Abstract Services; r, regulated compound required by Safe Drinking Water Act (SDWA); ur, unregulated compound required by SDWA; sd, unregulated compound required at the discretion of the State; $n$, not required by SDWA; c, included on USEPA's Drinking Water Contaminant Candidate List (U.S. Environmental Pro*ection Agency, 1998b)]

\begin{tabular}{|c|c|c|c|c|c|c|}
\hline $\begin{array}{c}\text { Volatile organic } \\
\text { compound } \\
\text { (common or trade name) }\end{array}$ & IUPAC name & $\begin{array}{c}\text { USEPA } \\
\text { contaminant } \\
\text { code }\end{array}$ & $\begin{array}{c}\text { CAS } \\
\text { number }\end{array}$ & Compound class & $\begin{array}{l}\text { Primary use } \\
\text { or source }\end{array}$ & SDWA \\
\hline trans-1,2-Dichloroethene & trans-1,2-Dichloroethene & 2979 & $156-60-5$ & Halogenated alkene & Solvent & $\mathrm{r}$ \\
\hline $\begin{array}{l}\text { Dichloromethane } \\
\text { (Methylene chloride) }\end{array}$ & Dichloromethane & 2964 & $75-09-2$ & Halogenated alkane & Solvent & $\mathrm{r}$ \\
\hline $\begin{array}{l}\text { 1,2-Dichloropropane } \\
\text { (Propylene dichloride) }\end{array}$ & 1,2-Dichloropropane & 2983 & $78-87-5$ & Halogenated alkane & Solvent & $\mathbf{r}$ \\
\hline $\begin{array}{l}\text { 1,3-Dichloropropane } \\
\text { (Trimethylene dichloride) }\end{array}$ & 1,3-Dichloropropane & 2412 & $142-28-9$ & Halogenated alkane & Organic synthesis & ur, c \\
\hline 2,2-Dichloropropane & 2,2-Dichloropropane & 2416 & $594-20-7$ & Halogenated alkane & Organic synthesis & ur, c \\
\hline 1,1-Dichloropropene & 1,1-Dichloropropene & 2410 & $563-58-6$ & Halogenated alkene & Organic synthesis & ur, c \\
\hline cis-1,3-Dichloropropene & cis-1,3-Dichloropropene & 2228 & $10061-01-5$ & Halogenated alkene & Fumigant & ur, c \\
\hline trans-1.3-Dichloropropene & trans-1,3-Dichloropropene & 2224 & $10061-02-6$ & Halogenated alkene & Fumigant & ur, c \\
\hline $\begin{array}{l}\text { cis- \& trans-1,3-Dichloropro- } \\
\text { pene }\end{array}$ & $\begin{array}{l}\text { 1,3-Dichloropropene, (mixed } \\
\text { isomers) }\end{array}$ & 2413 & $542-75-6$ & Halogenated alkene & Fumigant & $\mathrm{n}$ \\
\hline $\begin{array}{l}\text { Diethyl ether } \\
\text { (Ethyl ether) }\end{array}$ & 1,1-Oxybisethane & 2090 & $60-29-7$ & Ether & Solvent & $\mathrm{n}$ \\
\hline $\begin{array}{l}\text { Ethylbenzene } \\
\text { (Phenylethane) }\end{array}$ & Ethylbenzene & 2992 & $100-41-4$ & Alkyl benzene & Gasoline & $\mathrm{r}$ \\
\hline $\begin{array}{l}\text { Ethylene dibromide } \\
\text { (EDB) }\end{array}$ & 1,2-Dibromoethane & 2946 & $106-93-4$ & Halogenated alkane & Fumigant & $\mathrm{r}$ \\
\hline $\begin{array}{l}\text { Fluorotrichloromethane } \\
\text { (CFC 11; Freon } 11 \text { ) }\end{array}$ & Trichlorofluoromethane & 2218 & $75-69-4$ & Halogenated alkane & Refrigerant & sd \\
\hline Hexachlorobutadiene & $\begin{array}{l}\text { 1,1,2,3,4,4-Hexachloro-1,3- } \\
\text { butadiene }\end{array}$ & 2246 & $87-68-3$ & Halogenated alkene & Organic synthesis & $\mathrm{sd}, \mathrm{c}$ \\
\hline Hexachloroethane & 1,1,1,2,2,2-Hexachloroethane & 2225 & $67-72-1$ & Halogenated alkane & Solvent & $\mathrm{n}$ \\
\hline n-Hexane & $n$-Hexane & 2376 & $110-54-3$ & Alkane & Solvent & $\mathrm{n}$ \\
\hline Isopropylbenzene & (1-Methylethyl)benzene & 2994 & $98-82-8$ & Alkyl benzene & Organic synthesis & sd \\
\hline $\begin{array}{l}p \text {-Isopropyltoluene } \\
\text { (p-Cymene) }\end{array}$ & 1-Isopropyl-4-methylbenzene & 2030 & $99-87-6$ & Alkyl benzene & Organic synthesis & sd, c \\
\hline $\begin{array}{l}\text { Methyl butyl ketone } \\
\text { (Butyl methyl ketone; MBK) }\end{array}$ & 2-Hexanone & - & $591-78-6$ & Ketone & Solvent & $\mathrm{n}$ \\
\hline $\begin{array}{l}\text { Methyl ethyl ketone } \\
\text { (Ethyl methyl ketone; MEK) }\end{array}$ & 2-Butanone & 2247 & $78-93-3$ & Ketone & Solvent & $\mathrm{n}$ \\
\hline $\begin{array}{l}\text { Methyl isobutyl ketone } \\
\text { (Isobutyl methyl ketone; } \\
\text { MIBK) }\end{array}$ & 4-Methyl-2-pentanone & 2249 & $108-10-1$ & Ketone & Solvent & $\mathrm{n}$ \\
\hline Methyl methacrylate & Methyl 2-methyl-2-propenoate & 2295 & $80-62-8$ & Oxy alkene & Organic synthesis & $\mathrm{n}$ \\
\hline $\begin{array}{l}\text { Methyl tert-butyl ether } \\
\text { (MTBE) }\end{array}$ & 2-Methoxy-2-methylpropane & 2251 & $1634-04-4$ & Cyclic ether & Gasoline & c \\
\hline Monochlorobenzene & Chlorobenzene & 2989 & $108-90-7$ & Halogenated aromatic & Solvent & $\mathrm{r}$ \\
\hline Naphthalene & Naphthalene & 2248 & $91-20-3$ & Aromatic hydrocarbon & Hydrocarbon & $\mathrm{sd}, \mathrm{c}$ \\
\hline Nitrobenzene & Nitrobenzene & 2254 & $98-95-3$ & Nitro aromatic & Organic synthesis & $\mathrm{n}$ \\
\hline Pentachloroethane & 1,1,1,2,2,2-Pentachloro-ethane & 2327 & $76-01-7$ & Halogenated alkane & Solvent & $\mathrm{n}$ \\
\hline $\begin{array}{l}n \text {-Propylbenzene } \\
\text { (Isocumene) }\end{array}$ & $n$-Propylbenzene & 2998 & $103-65-1$ & Alkyl benzene & Solvent & sd \\
\hline Styrene & Ethenylbenzene & 2996 & $100-42-5$ & Aromatic hydrocarbon & Organic synthesis & $\mathrm{r}$ \\
\hline 1,1,1,2-Tetrachloroethane & 1,1,1,2-Tetrachloroethane & 2988 & $79-34-5$ & Halogenated alkane & Solvent & ur \\
\hline 1,1,2,2-Tetrachloroethane & 1,1,2,2-Tetrachloroethane & 2986 & $630-20-6$ & Halogenated alkane & Solvent & ur, c \\
\hline
\end{tabular}


Appendix 1. Volatile organic compounds included in analyses of drinking water for randomly selected community water systems in the study area,1993-98-Continued

[IUPAC, International Union of Pure and Applied Chemistry; USEPA. U.S. Environmental Protection Agency; CAS, Chemical Abstract Services; r, regulated compound required by Safe Drinking Water Act (SDWA); ur, unregulated compound required by SDWA; sd, unregulated compound required at the discretion of the State; n, not required by SDWA; c, included on USEPA's Drinking Water Contaminant Candidate List (U.S. Environmental Protection Agency, 1998b)]

\begin{tabular}{|c|c|c|c|c|c|c|}
\hline $\begin{array}{c}\text { Volatile organic } \\
\text { compound } \\
\text { (common or trade name) }\end{array}$ & IUPAC name & $\begin{array}{c}\text { USEPA } \\
\text { contaminant } \\
\text { code }\end{array}$ & $\begin{array}{c}\text { CAS } \\
\text { number }\end{array}$ & Compound class & $\begin{array}{c}\text { Primary use } \\
\text { or source }\end{array}$ & SDWA \\
\hline $\begin{array}{l}\text { Tetrachloroethylene } \\
\text { (Perchloroethene; PCE) }\end{array}$ & Tetrachloroethene & 2987 & $127-18-4$ & Halogenated alkene & Solvent & $\mathbf{r}$ \\
\hline Tetrahydrofuran & 1,4-Epoxybutane & 2263 & $109-99-9$ & Cyclic alkane & Solvent & $\mathrm{n}$ \\
\hline Toluene & Methylbenzene & 2991 & $108-88-3$ & Alkyl benzene & Gasoline & $r$ \\
\hline $\begin{array}{l}\text { 1,1,2-Trichloro-1,2.2-trifluoro- } \\
\text { ethane } \\
\text { (CFC 113; Freon 113) }\end{array}$ & $\begin{array}{l}\text { 1,1,2-Trichloro-1,2,2-trifluoro- } \\
\text { ethane }\end{array}$ & 2904 & $76-13-1$ & Halogenated alkane & Refrigerant & $\mathrm{n}$ \\
\hline 1,2,3-Trichlorobenzene & 1,2,3-Trichlorobenzene & 2420 & $87-61-6$ & Halogenated aromatic & Organic synthesis & sd \\
\hline 1,2,4-Trichlorobenzene & 1,2.4-Trichlorobenzene & 2378 & $120-82-1$ & Halogenated aromatic & Solvent & $r$ \\
\hline $\begin{array}{l}\text { 1,1,1-Trichloroethane } \\
\text { (Methyl chloroform) }\end{array}$ & 1,1,1-Trichloroethane & 2981 & $71-55-6$ & Halogenated alkane & Solvent & $\mathrm{r}$ \\
\hline $\begin{array}{l}\text { 1,1,2-Trichloroethane } \\
\text { (Vinyl trichloride) }\end{array}$ & I,1,2-Trichloroethane & 2985 & $79-00-5$ & Halogenated alkane & Solvent & r \\
\hline $\begin{array}{l}\text { Trichloroethylene } \\
\text { (TCE) }\end{array}$ & Trichloroethene & 2984 & $79-01-6$ & Halogenated alkene & Solvent & $\mathbf{r}$ \\
\hline $\begin{array}{l}\text { 1,2,3-Trichloropropane } \\
\text { (Allyl trichloride) }\end{array}$ & 1,2,3-Trichloropropane & 2414 & $96-18-4$ & Halogenated alkane & Solvent & ur \\
\hline $\begin{array}{l}\text { Trihalomethanes, total } \\
\text { (THMs) }\end{array}$ & & 2950 & - & & $\begin{array}{l}\text { Disinfectant by-prod- } \\
\text { ucts }\end{array}$ & $\mathbf{r}$ \\
\hline $\begin{array}{l}\text { 1,2,3-Trimethylbenzene } \\
\text { (Hemimellitene) }\end{array}$ & 1,2,3-Trimethylbenzene & - & $526-73-8$ & Alkyl benzene & Gasoline & $\mathrm{n}$ \\
\hline $\begin{array}{l}\text { 1,2,4-Trimethylbenzene } \\
\text { (Pseudocumene) }\end{array}$ & 1,2,4-Trimethylbenzene & 2418 & $95-63-6$ & Alkyl benzene & Organic synthesis & sd, c \\
\hline $\begin{array}{l}\text { 1,3,5-Trimethylbenzene } \\
\text { (Mesitylene) }\end{array}$ & 1,3,5-Trimethylbenzene & 2424 & $108-67-8$ & Alkyl benzene & Gasoline & sd \\
\hline Vinyl chloride & Chloroethene & 2976 & $75-01-4$ & Halogenated alkene & Organic synthesis & $\mathrm{r}$ \\
\hline$m$-Xylene & 1,3-Dimethylbenzene & 2995 & $108-38-3$ & Alkyl benzene & Gasoline & $\mathrm{n}$ \\
\hline$o$-Xylene & 1,2-Dimethylbenzene & 2997 & $95-47-6$ & Alkyl benzene & Gasoline & $\mathrm{n}$ \\
\hline$p$-Xylene & 1.4-Dimethylbenzene & 2962 & $106-42-3$ & Alkyl benzene & Gasoline & $\mathrm{n}$ \\
\hline$m$ - \& p-Xylene & 1,3-\& 1,4-Dimethylbenzene & 2963 & $\begin{array}{l}106-42-3 \\
108-38-3\end{array}$ & Alkyl benzene & Gasoline & $\mathrm{n}$ \\
\hline Xylenes, total & $\begin{array}{l}\text { Dimethylbenzene, mixed iso- } \\
\text { mers }\end{array}$ & 2955 & $1330-20-7$ & Alkyl benzene & Gasoline & $\mathbf{r}$ \\
\hline
\end{tabular}




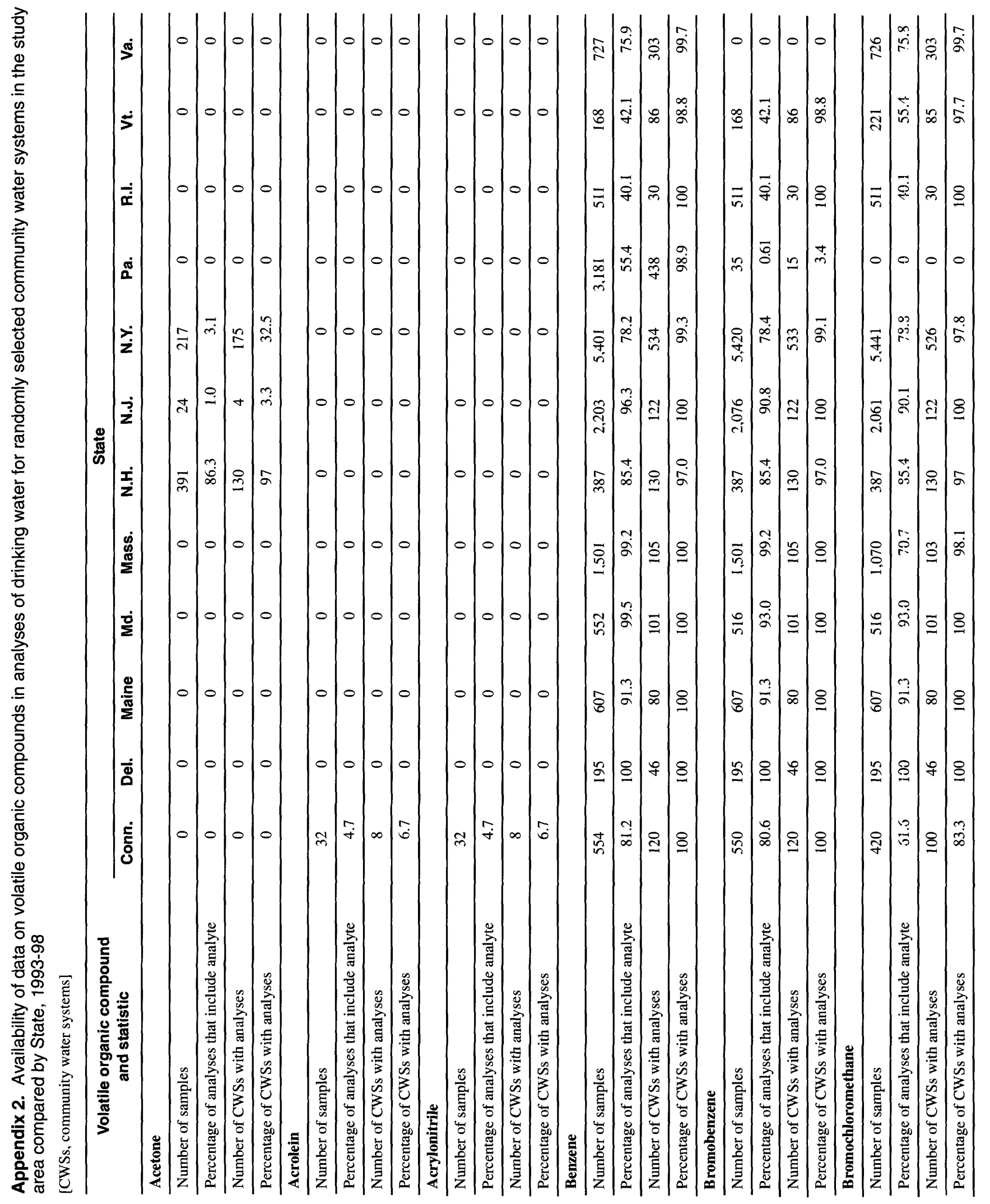




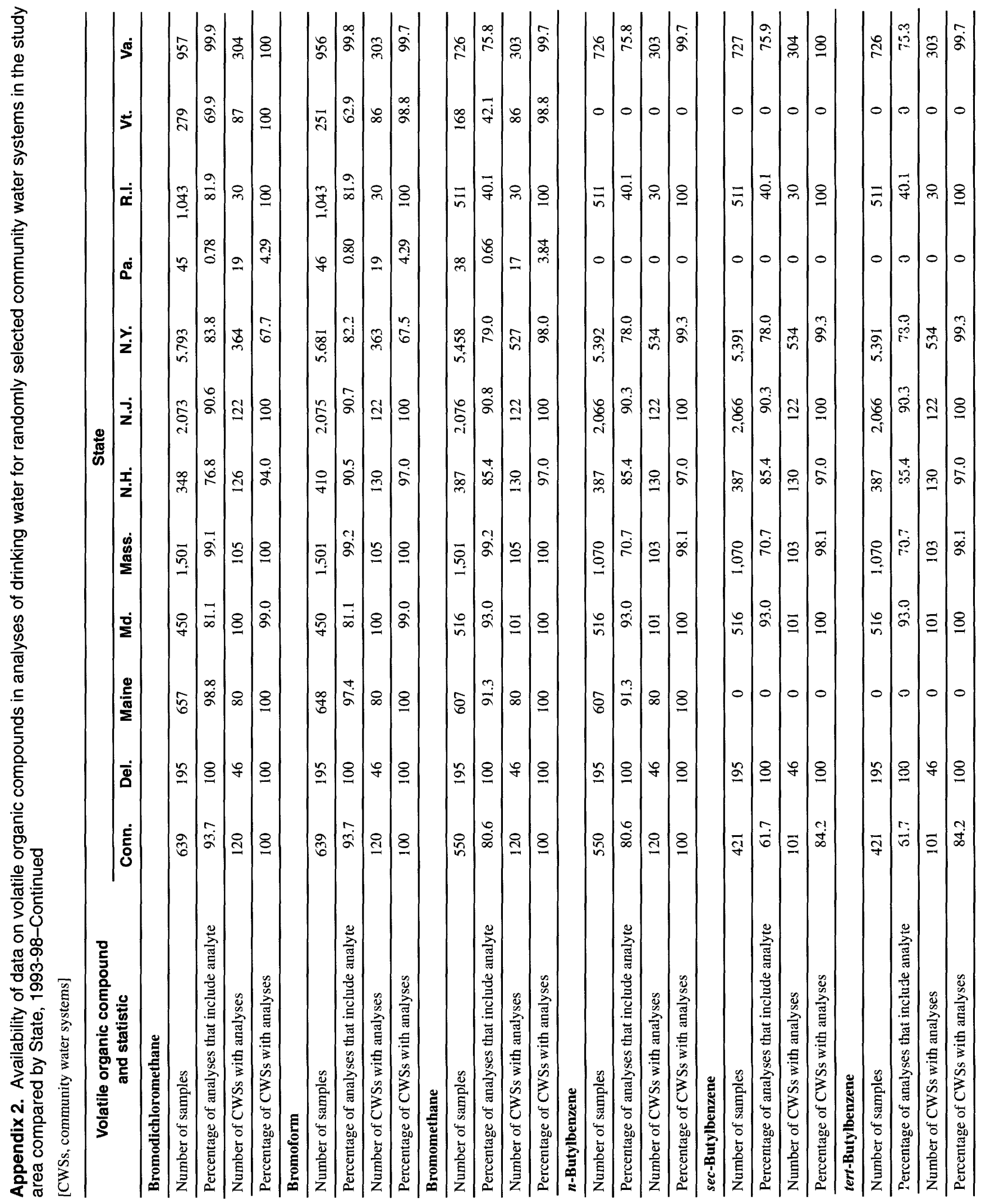




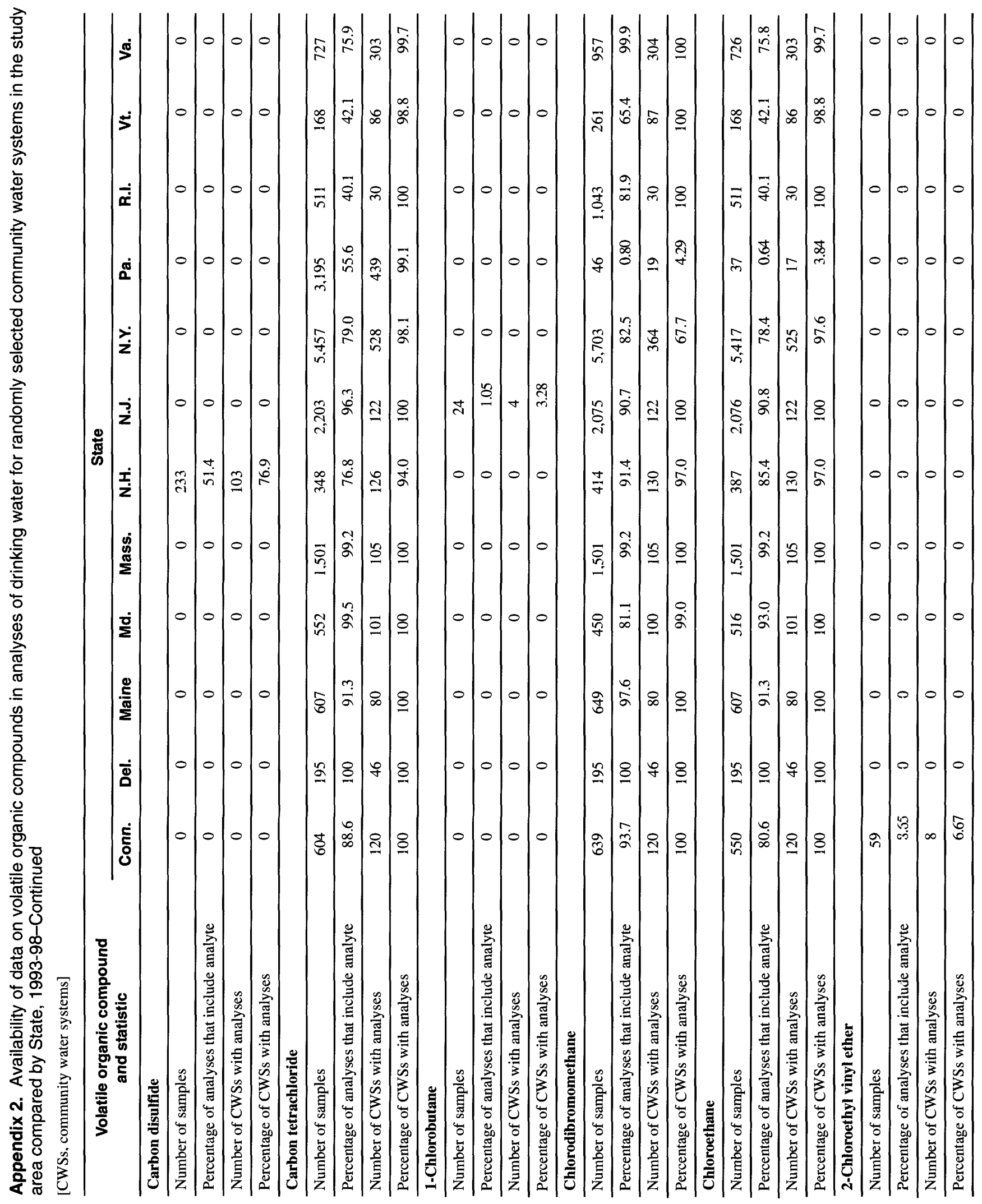




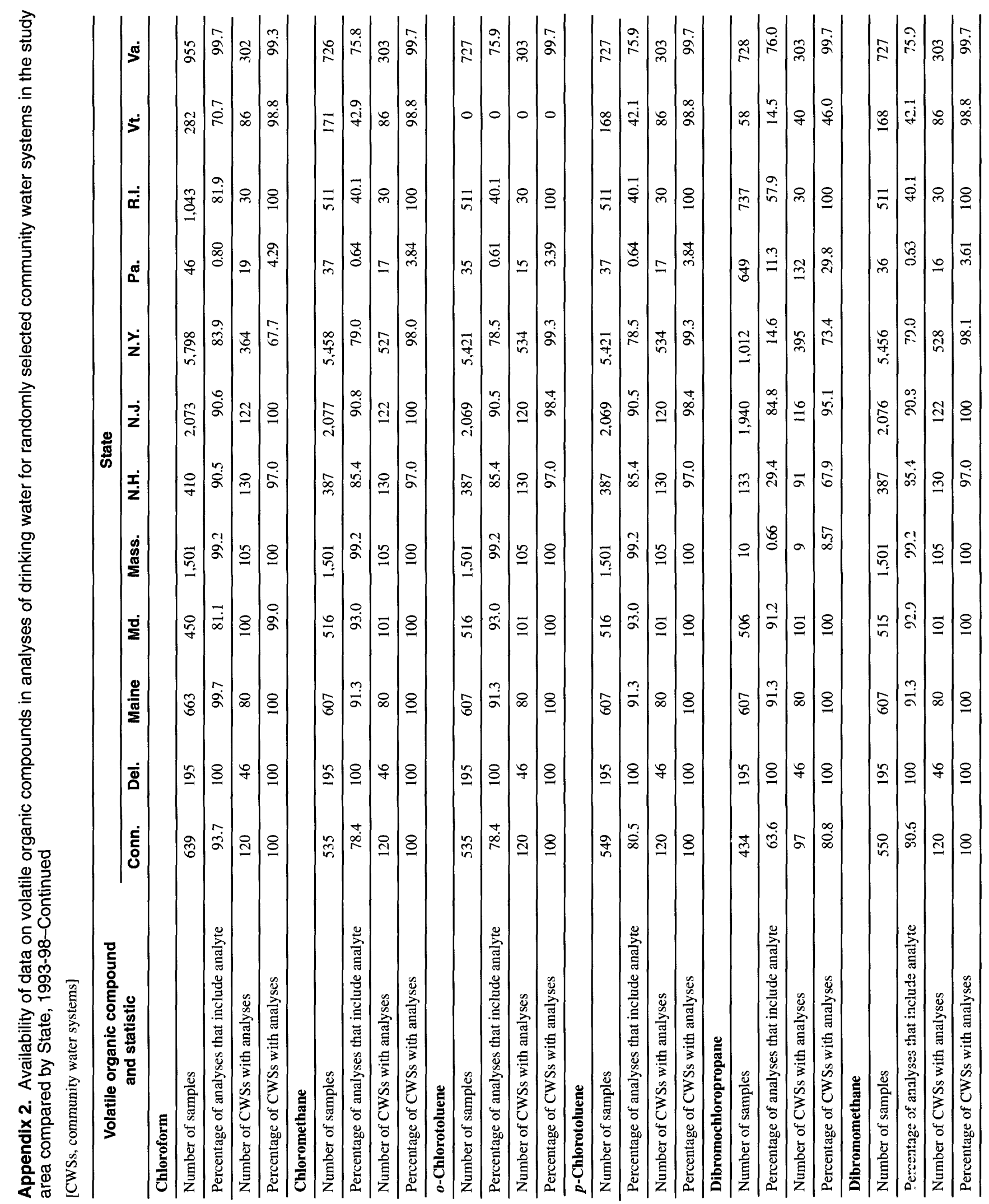




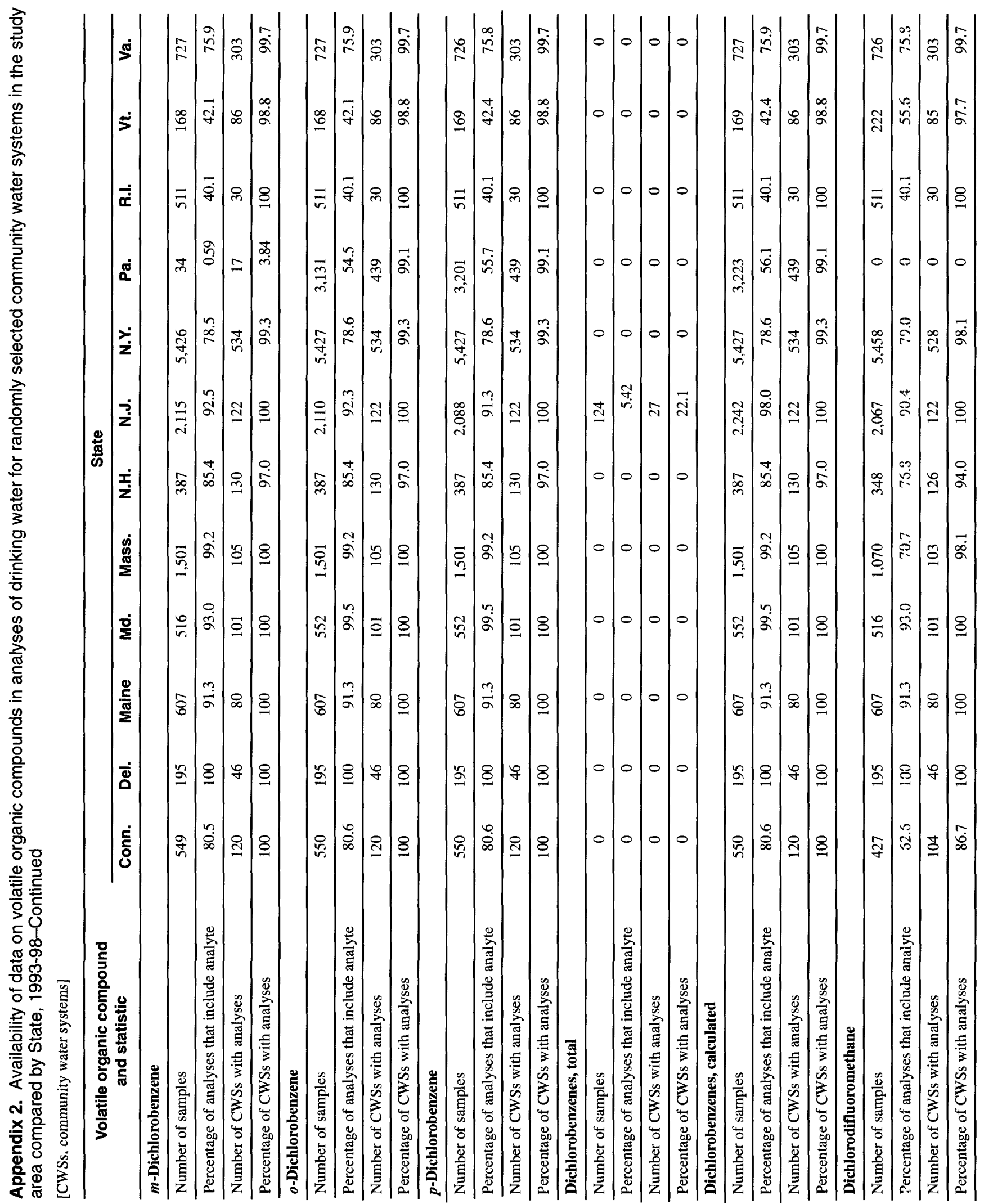




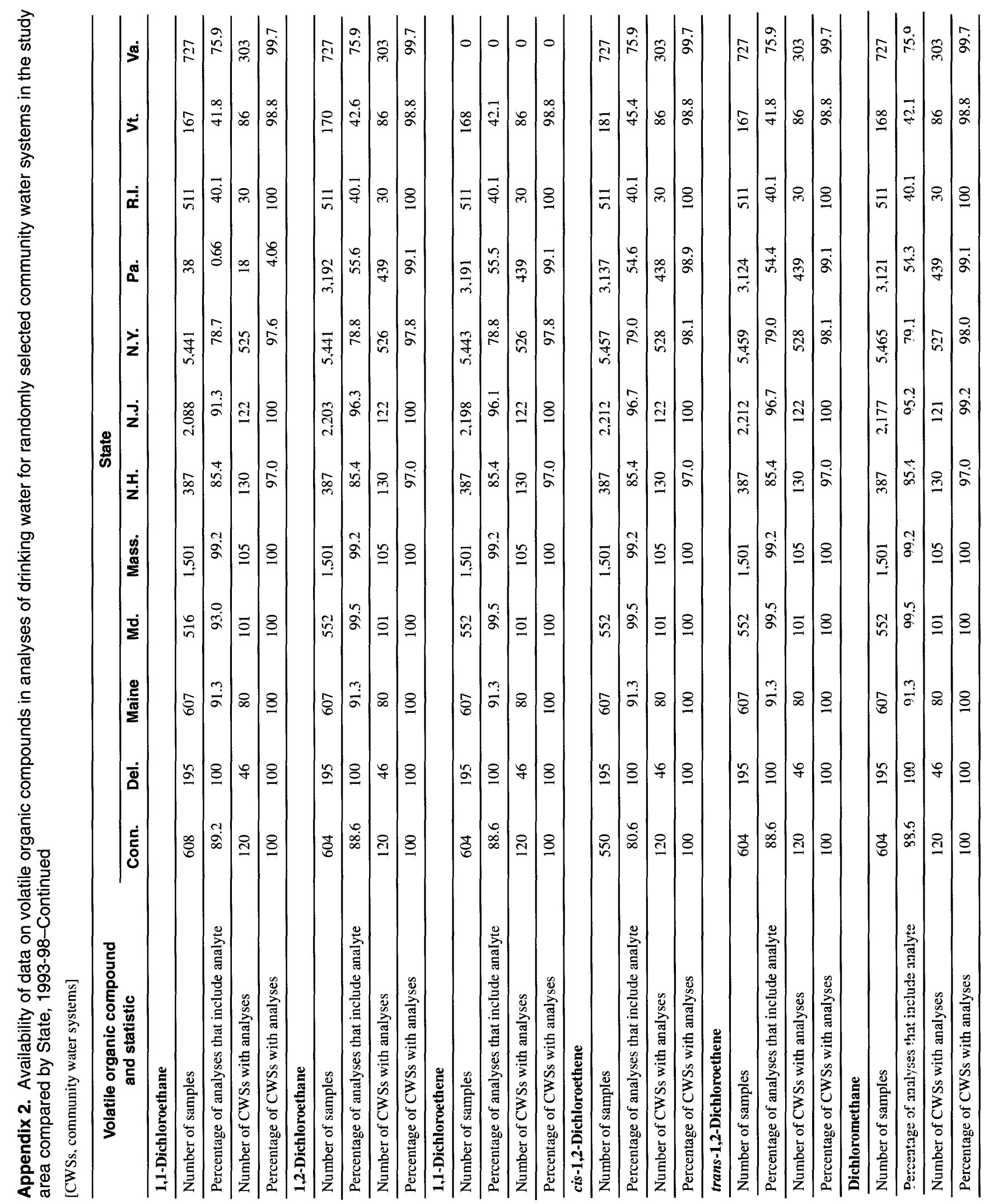




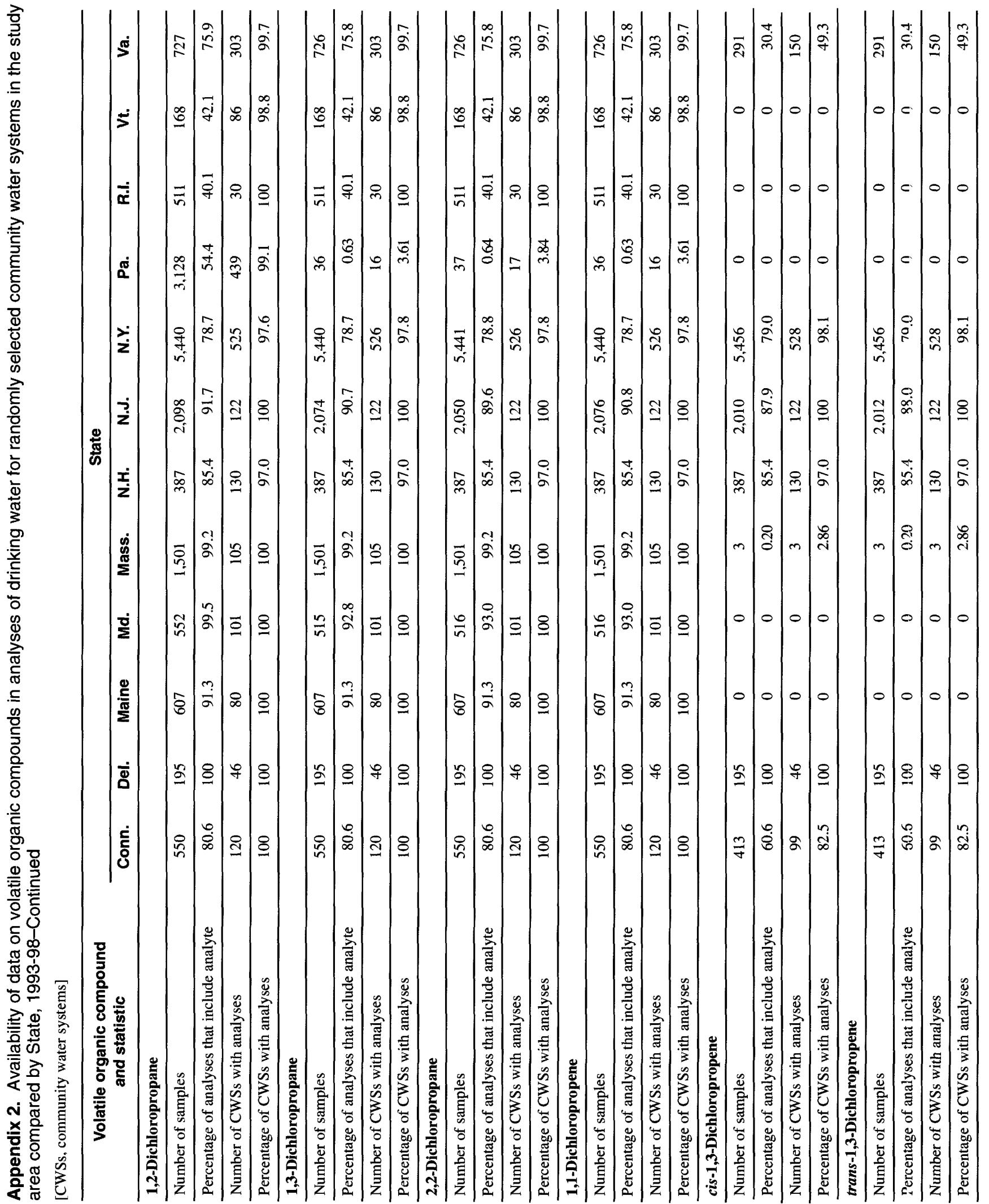




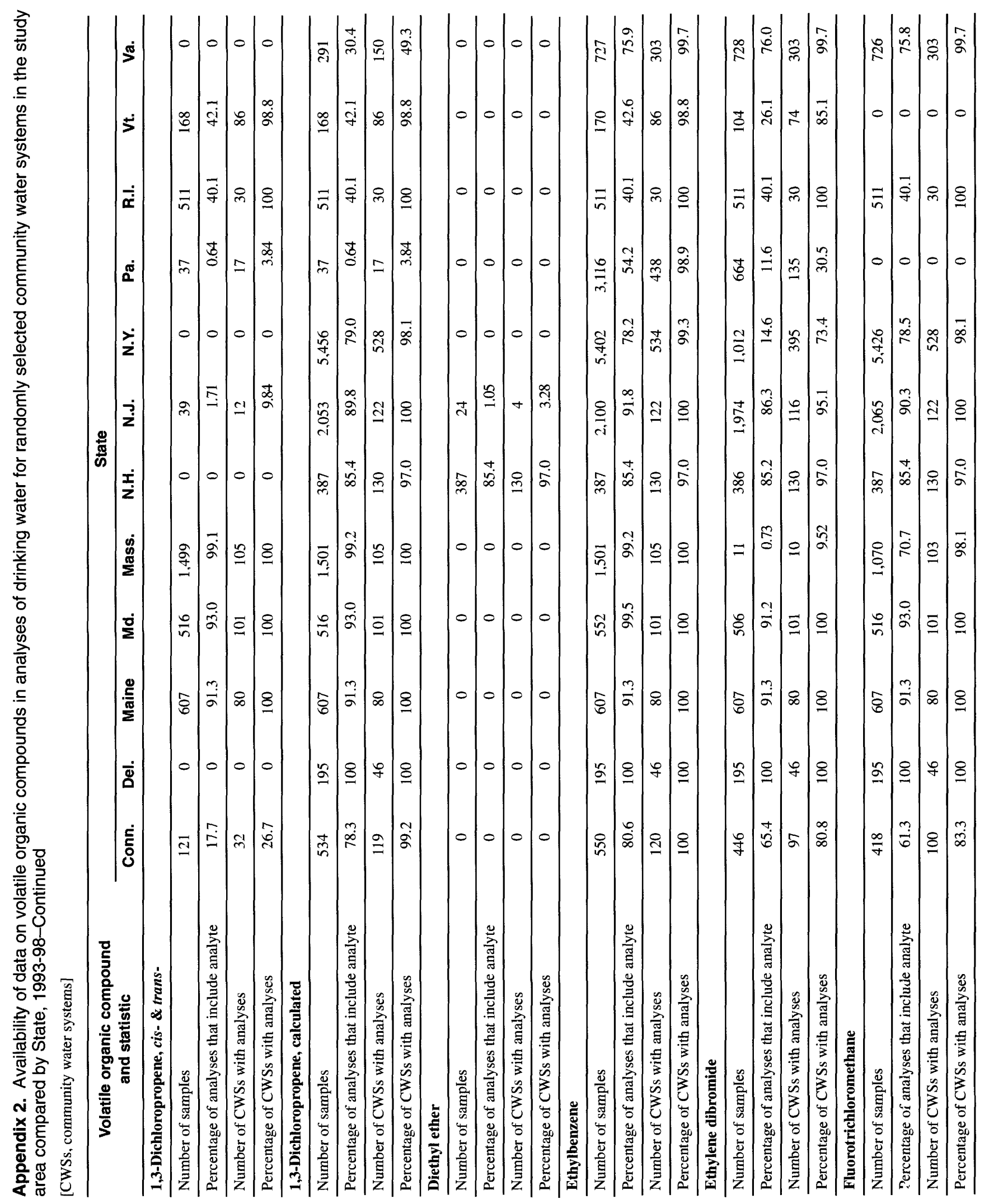




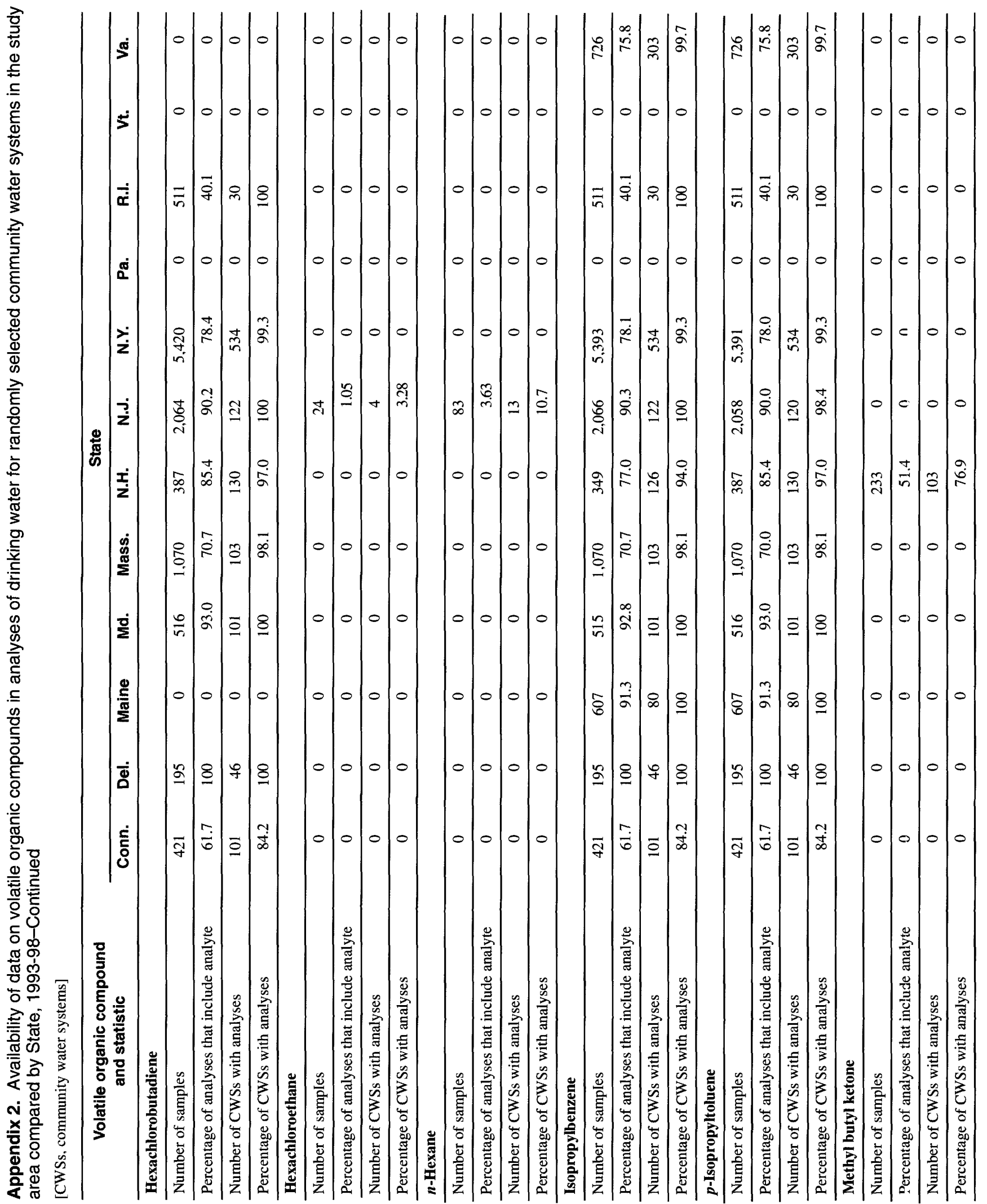




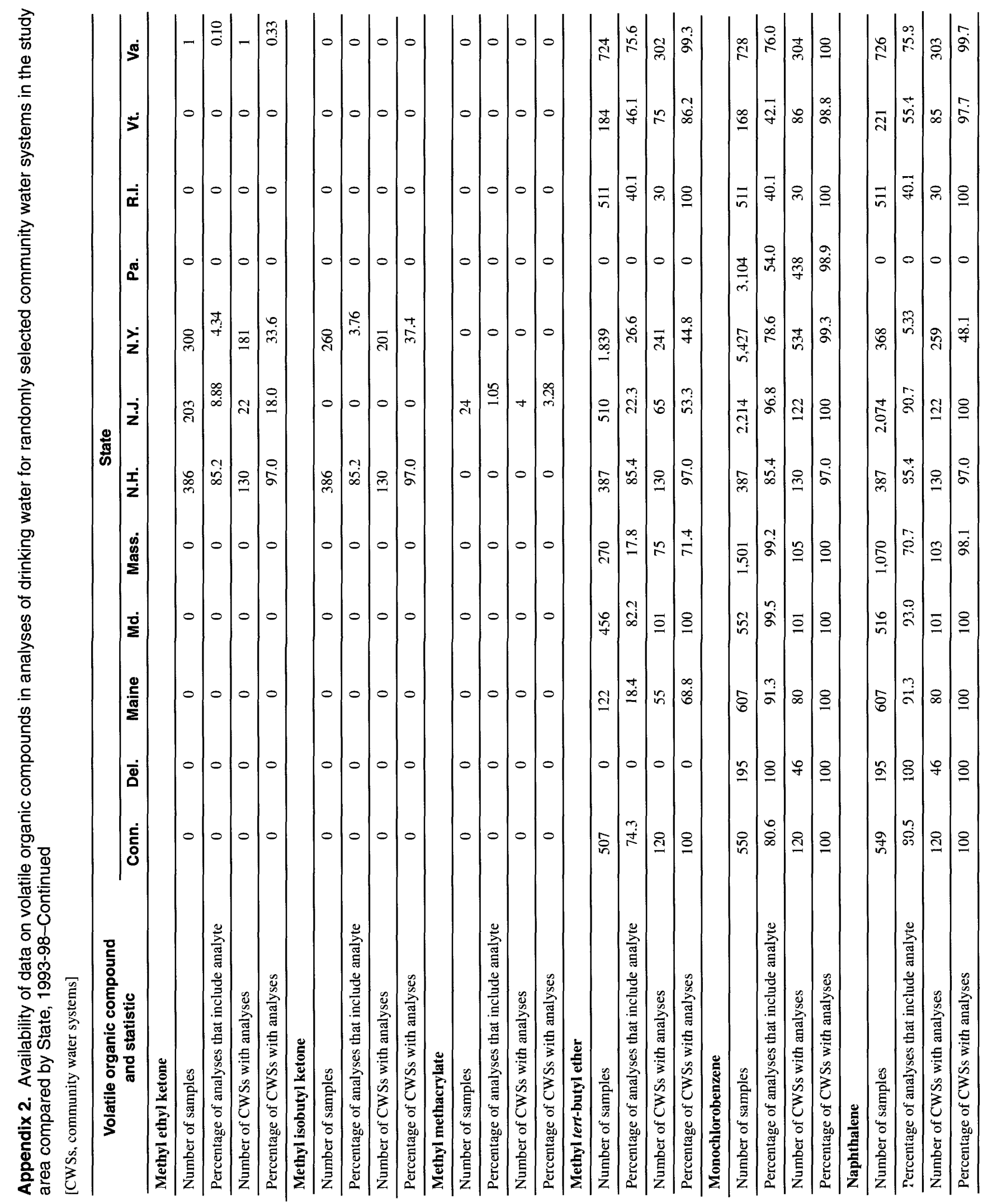




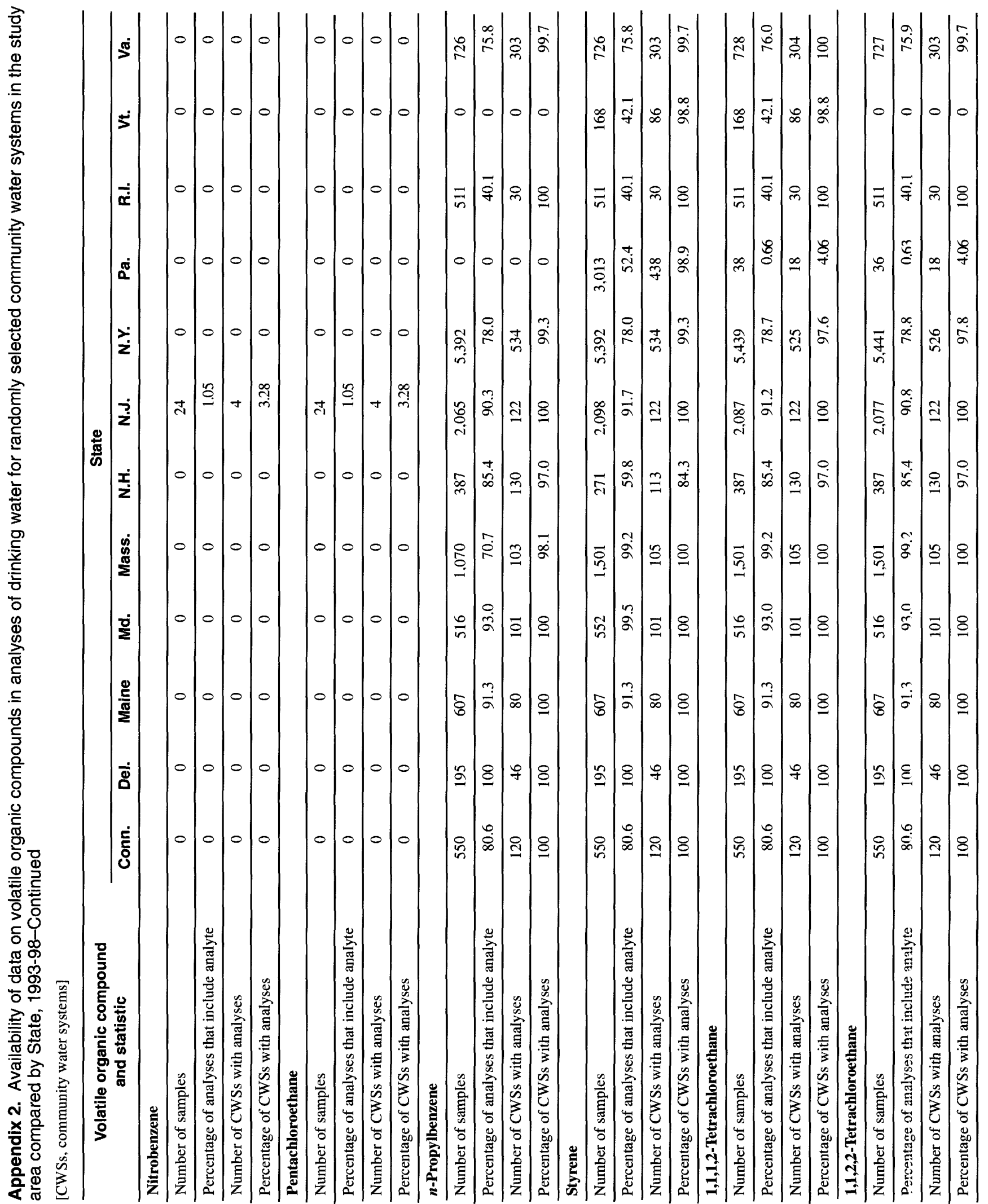




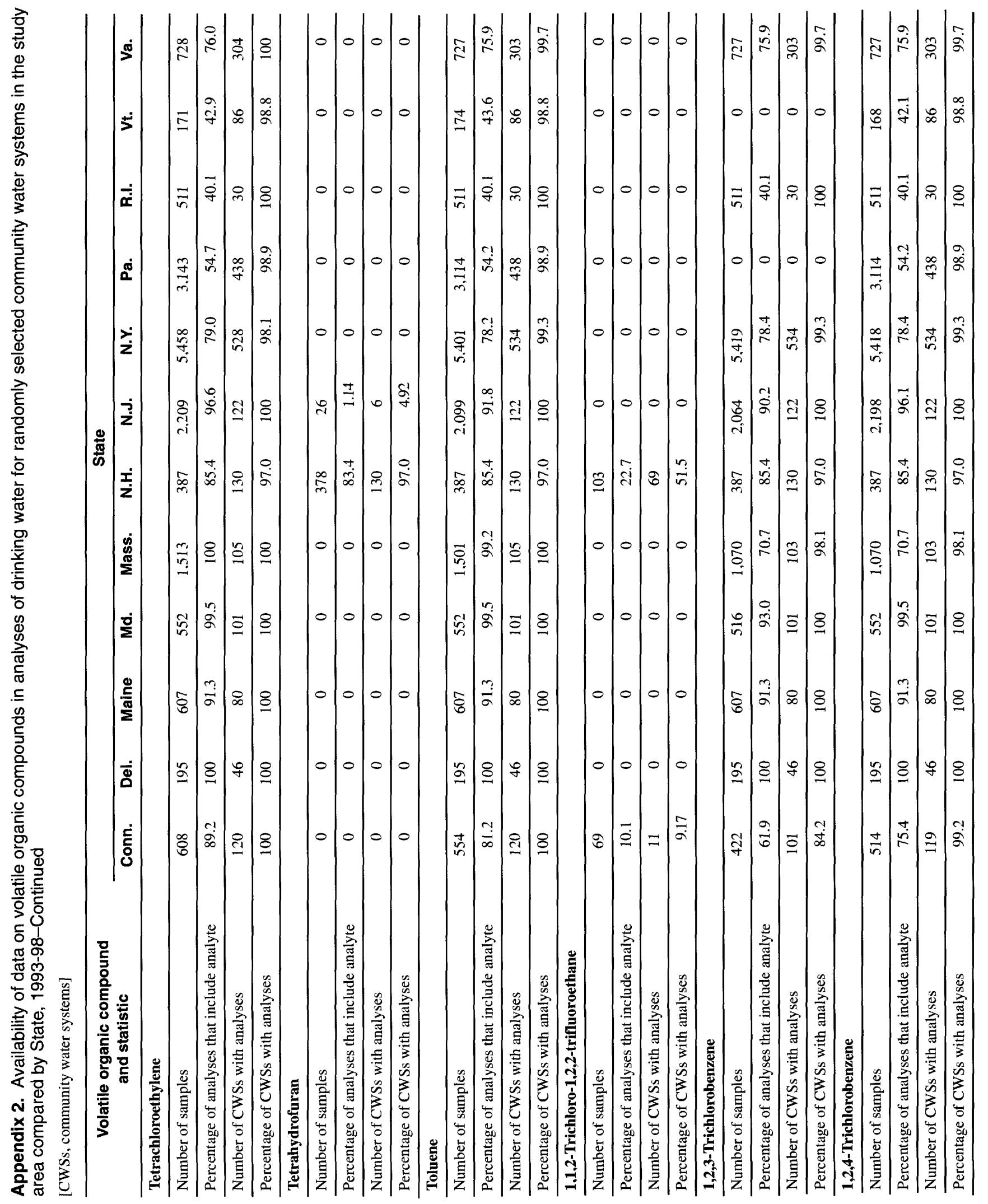




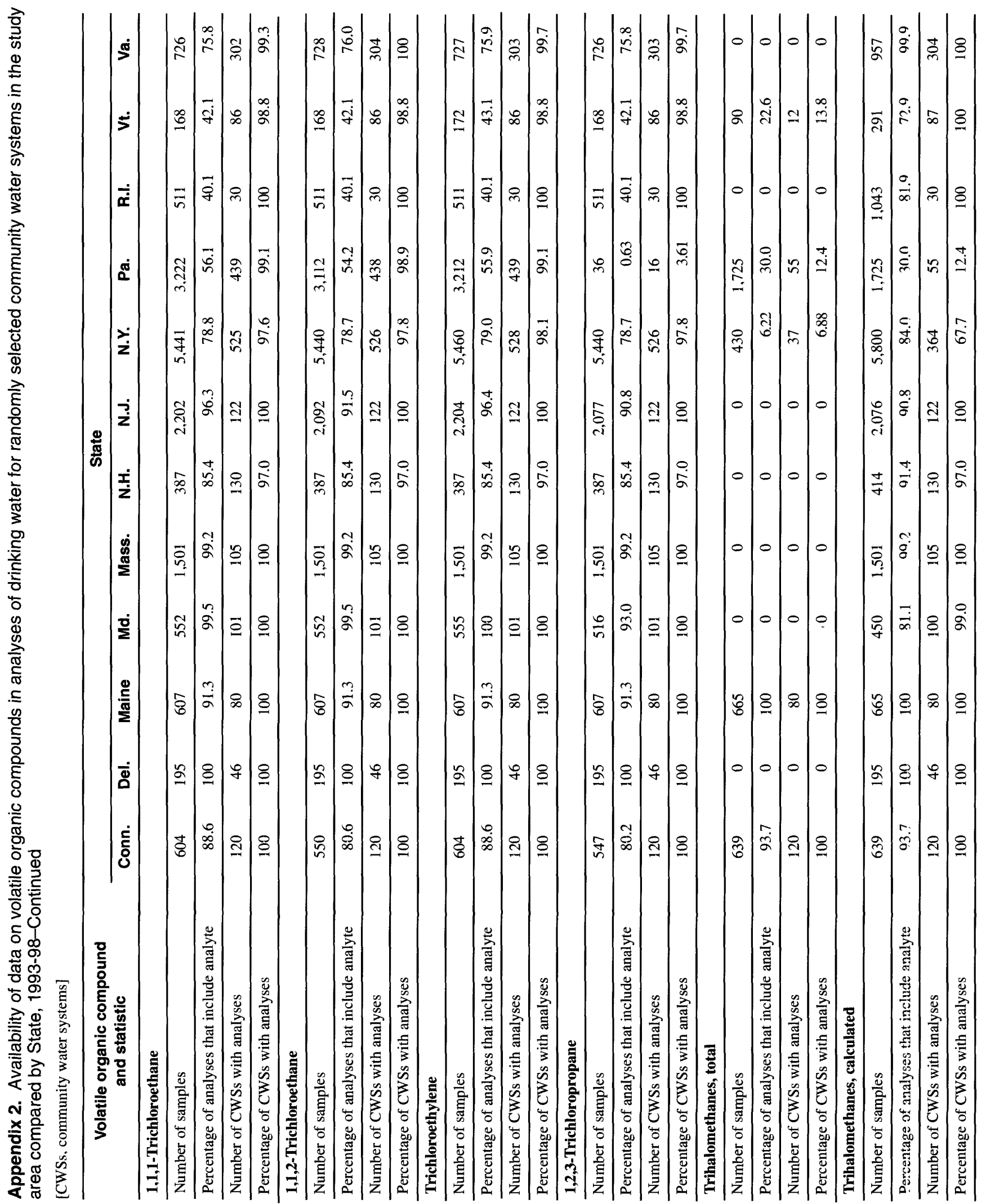




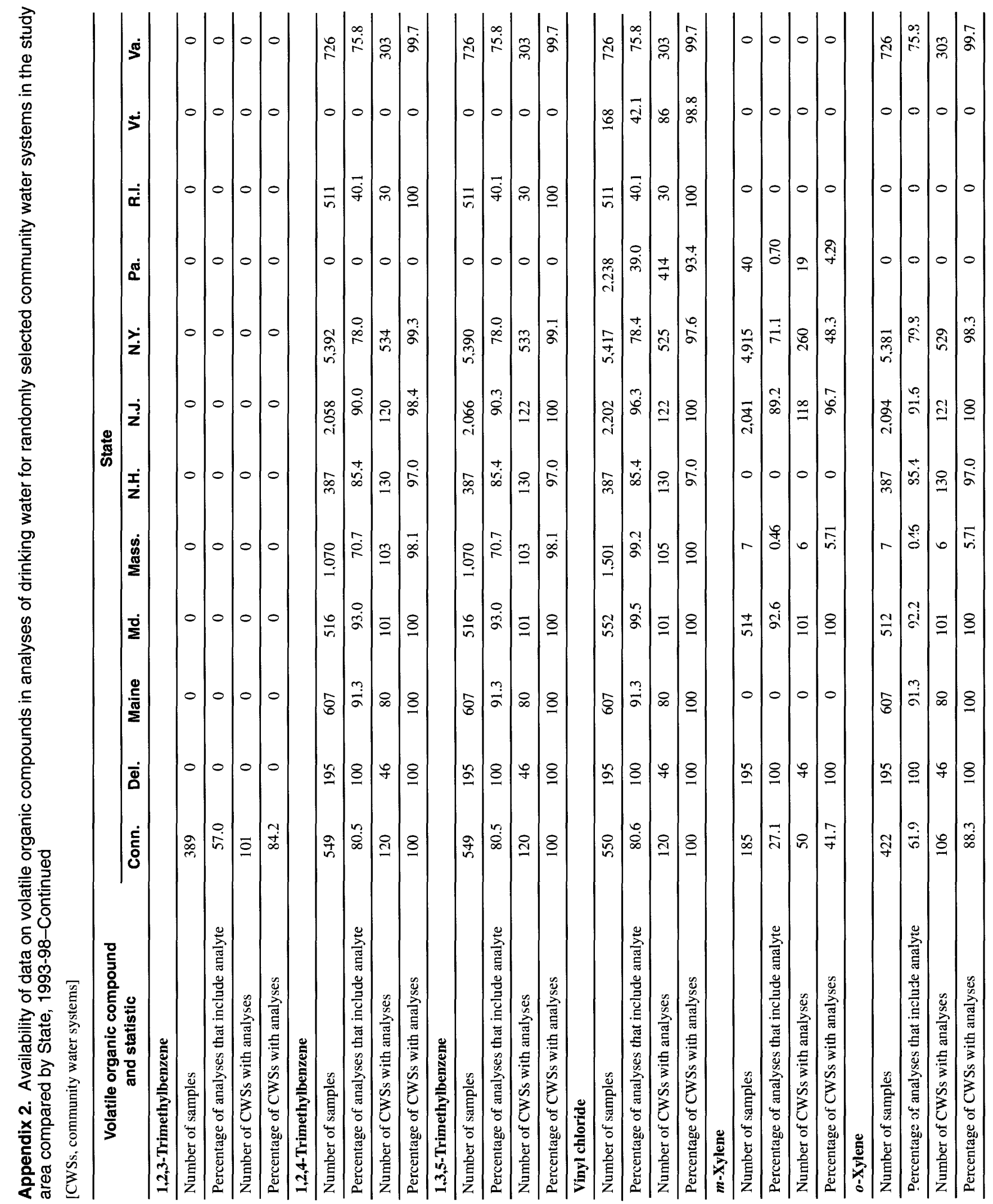




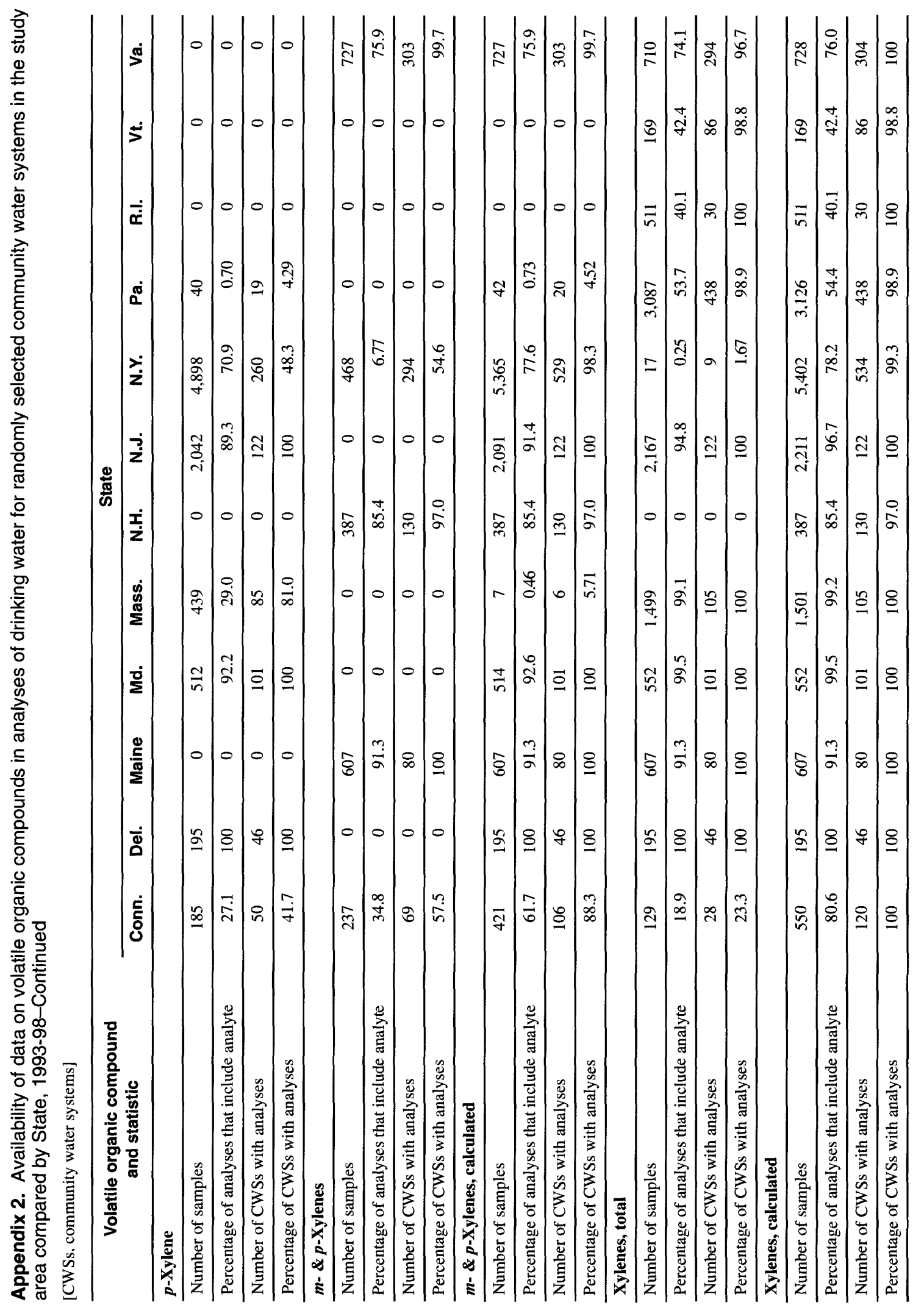


Appendix 3. Frequency of reporting and frequency of detection of volatile organic compounds included in analyses of drinking water for randomly selected community water systems in the study area compared by reporting levels, 1993-98

[Data for any reporting level include all data reported by States for specified analyte without regard to differences in minimum reporting levels or method detection limits, whereas data for specific censoring levels have been censored to remove samples with a reporting level higher than the specifie $f$ censoring level, and all reported detectable concentrations of the specified analyte below the censoring level have been converted to "less than" values; $\mu \mathrm{g} / \mathrm{L}$, micrograms per liter; CWSs, community water systems]

\begin{tabular}{|c|c|c|c|c|c|c|c|}
\hline \multirow{2}{*}{ Volatile organic compound and statistic } & \multicolumn{7}{|c|}{ Reporting or censoring level } \\
\hline & Any & $20 \mu \mathrm{g} / \mathrm{L}$ & $10 \mu \mathrm{g} / \mathrm{L}$ & $5.0 \mu \mathrm{g} / \mathrm{L}$ & $2.0 \mu \mathrm{g} / \mathrm{L}$ & $1.0 \mu \mathrm{g} / \mathrm{L}$ & $0.5 \mu \mathrm{g} / \mathrm{L}$ \\
\hline \multicolumn{8}{|l|}{ Acetone } \\
\hline Number of analyses & 632 & 632 & 632 & 421 & 421 & 420 & 420 \\
\hline Percentage of all analyses that include analyte & 2.9 & 2.9 & 2.9 & 1.9 & 1.9 & 1.9 & 1.9 \\
\hline Number of detections & 12 & 6 & 12 & 12 & 12 & 12 & 12 \\
\hline Percentage of analyses with detections & 1.9 & 1.0 & 1.9 & 2.8 & 2.8 & 2.9 & 2.9 \\
\hline Number of CWSs with analyses & 309 & 309 & 309 & 139 & 139 & 138 & 138 \\
\hline Percentage of all CWSs with analyses & 14.6 & 14.6 & 14.6 & 6.6 & 6.6 & 6.5 & 6.5 \\
\hline Number of CWSs with detections & 9 & 4 & 9 & 9 & 9 & 9 & 9 \\
\hline Percentage of CWSs with detections & 2.9 & 1.3 & 2.9 & 6.5 & 6.5 & 6.5 & 6.5 \\
\hline \multicolumn{8}{|l|}{ Acrolein } \\
\hline Number of analyses & 32 & 32 & 32 & 32 & 32 & 30 & 24 \\
\hline Percentage of all analyses that include analyte & 0.2 & 0.2 & 0.2 & 0.2 & 0.2 & 0.1 & 0.1 \\
\hline Number of detections & 0 & 0 & 0 & 0 & 0 & 0 & 0 \\
\hline Percentage of analyses with detections & 0 & 0 & 0 & 0 & 0 & 0 & 0 \\
\hline Number of CWSs with analyses & 8 & 8 & 8 & 8 & 8 & 7 & 7 \\
\hline Percentage of all CWSs with analyses & 0.4 & 0.4 & 0.4 & 0.4 & 0.4 & 0.3 & 0.3 \\
\hline Number of CWSs with detections & 0 & 0 & 0 & 0 & 0 & 0 & 0 \\
\hline Percentage of CWSs with detections & 0 & 0 & 0 & 0 & 0 & 0 & 0 \\
\hline \multicolumn{8}{|l|}{ Acrylonitrile } \\
\hline Number of analyses & 32 & 32 & 32 & 32 & 32 & 32 & 26 \\
\hline Percentage of all analyses that include analyte & 0.2 & 0.2 & 0.2 & 0.2 & 0.2 & 0.2 & 0.1 \\
\hline Number of detections & 0 & 0 & 0 & 0 & 0 & 0 & 0 \\
\hline Percentage of analyses with detections & 0 & 0 & 0 & 0 & 0 & 0 & 0 \\
\hline Number of CWSs with analyses & 8 & 8 & 8 & 8 & 8 & 8 & 8 \\
\hline Percentage of all CWSs with analyses & 0.4 & 0.4 & 0.4 & 0.4 & 0.4 & 0.4 & 0.4 \\
\hline Number of CWSs with detections & 0 & 0 & 0 & 0 & 0 & 0 & 0 \\
\hline Percentage of CWSs with detections & 0 & 0 & 0 & 0 & 0 & 0 & 0 \\
\hline \multicolumn{8}{|l|}{ Benzene } \\
\hline Number of analyses & 15,987 & 15,987 & 15,987 & 15,987 & 15,986 & 15,986 & 15,969 \\
\hline Percentage of all analyses that include analyte & 73.9 & 73.9 & 73.9 & 73.9 & 73.9 & 73.9 & 73.8 \\
\hline Number of detections & 52 & 3 & 3 & 4 & 15 & 30 & 46 \\
\hline Percentage of analyses with detections & 0.3 & 0.02 & 0.02 & 0.03 & 0.09 & 0.2 & 0.3 \\
\hline Number of CWSs with analyses & 2,095 & 2,095 & 2,095 & 2,095 & 2,095 & 2,095 & 2,095 \\
\hline Percentage of all CWSs with analyses & 99.3 & 99.3 & 99.3 & 99.3 & 99.3 & 99.3 & 99.3 \\
\hline Number of CWSs with detections & 30 & 1 & 1 & 2 & 8 & 16 & 28 \\
\hline Percentage of CWSs with detections & 1.4 & 0.05 & 0.05 & 0.1 & 0.4 & 0.8 & 1.3 \\
\hline
\end{tabular}


Appendix 3. Frequency of reporting and frequency of detection of volatile organic compounds included in analyses of drinking water for randomly selected community water systems in the study area compared by reporting levels, 1993-98-Continued

[Data for any reporting level include all data reported by States for specified analyte without regard to differences in minimum reporting levels or method detection limits, whereas data for specific censoring levels have been censored to remove samples with a reporting level higher than the specified censoring level, and all reported detectable concentrations of the specified analyte below the censoring level have been converted to "less than" values; $\mu \mathrm{g} / \mathrm{L}$, micrograms per liter; CWSs, community water systems]

\begin{tabular}{|c|c|c|c|c|c|c|c|}
\hline \multirow{2}{*}{ Volatile organic compound and statistic } & \multicolumn{7}{|c|}{ Reporting or censoring level } \\
\hline & Any & $20 \mu \mathrm{g} / \mathrm{L}$ & $10 \mu \mathrm{g} / \mathrm{L}$ & $5.0 \mu \mathrm{g} / \mathrm{L}$ & $2.0 \mu \mathrm{g} / \mathrm{L}$ & $1.0 \mu \mathrm{g} / \mathrm{L}$ & $0.5 \mu \mathrm{g} / \mathrm{L}$ \\
\hline \multicolumn{8}{|l|}{ Bromobenzene } \\
\hline Number of analyses & 11,966 & 11,966 & 11,966 & 11,966 & 11,966 & 11,966 & 11,415 \\
\hline Percentage of all analyses that include analyte & 55.3 & 55.3 & 55.3 & 55.3 & 55.3 & 55.3 & 52.8 \\
\hline Number of detections & 0 & 0 & 0 & 0 & 0 & 0 & 0 \\
\hline Percentage of analyses with detections & 0 & 0 & 0 & 0 & 0 & 0 & 0 \\
\hline Number of CWSs with analyses & 1,368 & 1,368 & 1,368 & 1,368 & 1,368 & 1,368 & 1.341 \\
\hline Percentage of all CWSs with analyses & 64.8 & 64.8 & 64.8 & 64.8 & 64.8 & 64.8 & 63.6 \\
\hline Number of CWSs with detections & 0 & 0 & 0 & 0 & 0 & 0 & 0 \\
\hline Percentage of CWSs with detections & 0 & 0 & 0 & 0 & 0 & 0 & 0 \\
\hline \multicolumn{8}{|l|}{ Bromochloromethane } \\
\hline Number of analyses & 12,155 & 12,155 & 12,155 & 12,155 & 12,155 & 12,155 & 11,602 \\
\hline Percentage of all analyses that include analyte & 56.2 & 56.2 & 56.2 & 56.2 & 56.2 & 56.2 & 53.6 \\
\hline Number of detections & 10 & 0 & 0 & 1 & 2 & 3 & 9 \\
\hline Percentage of analyses with detections & 0.08 & 0 & 0 & 0.01 & 0.02 & 0.02 & 0.08 \\
\hline Number of CWSs with analyses & 1,626 & 1,626 & 1,626 & 1,626 & 1,626 & 1,626 & 1,599 \\
\hline Percentage of all CWSs with analyses & 77.1 & 77.1 & 77.1 & 77.1 & 77.1 & 77.1 & 75.8 \\
\hline Number of CWSs with detections & 10 & 0 & 0 & 1 & 2 & 3 & 9 \\
\hline Percentage of CWSs with detections & 0.6 & 0 & 0 & 0.06 & 0.1 & 0.2 & 0.6 \\
\hline \multicolumn{8}{|l|}{ Bromodichloromethane } \\
\hline Number of analyses & 13,980 & 13,980 & 13,980 & 13,979 & 13,975 & 13,877 & 13,206 \\
\hline Percentage of all analyses that include analyte & 64.6 & 64.6 & 64.6 & 64.6 & 64.6 & 64.1 & 61.0 \\
\hline Number of detections & 2,813 & 76 & 430 & 1,213 & 2,084 & 2,482 & 2,751 \\
\hline Percentage of analyses with detections & 20.1 & 0.5 & 3.1 & 8.7 & 14.9 & 17.9 & 20.8 \\
\hline Number of CWSs with analyses & 1,503 & 1,503 & 1.503 & 1,503 & 1,503 & 1,500 & 1.479 \\
\hline Percentage of all CWSs with analyses & 71.2 & 71.2 & 71.2 & 71.2 & 71.2 & 71.1 & 70.1 \\
\hline Number of CWSs with detections & 486 & 16 & 70 & 177 & 299 & 401 & 483 \\
\hline Percentage of CWSs with detections & 32.3 & 1.1 & 4.7 & $\mathrm{I} 1.8$ & 19.9 & 26.7 & 32.7 \\
\hline \multicolumn{8}{|l|}{ Bromoform } \\
\hline Number of analyses & 13,895 & 13,895 & 13,895 & 13,887 & 13,871 & 13,569 & 12,323 \\
\hline Percentage of all analyses that include analyte & 64.2 & 64.2 & 64.2 & 64.2 & 64.1 & 62.7 & 57.0 \\
\hline Number of detections & 728 & 9 & 27 & 92 & 226 & 416 & 716 \\
\hline Percentage of analyses with detections & 5.2 & 0.06 & 0.2 & 0.7 & 1.6 & 3.1 & 5.8 \\
\hline Number of CWSs with analyses & 1,504 & 1,504 & 1,504 & 1,504 & 1,504 & 1,478 & 1,451 \\
\hline Percentage of all CWSs with analyses & 71.3 & 71.3 & 71.3 & 71.3 & 71.3 & 70.0 & 68.8 \\
\hline Number of CWSs with detections & 193 & 6 & 14 & 32 & 72 & 119 & 193 \\
\hline Percentage of CWSs with detections & 12.8 & 0.4 & 0.9 & 2.1 & 4.8 & 8.0 & 13.3 \\
\hline
\end{tabular}


Appendix 3. Frequency of reporting and frequency of detection of volatile organic compounds included in analyses of drinking water for randomly selected community water systems in the study area compared by reporting levels, 1993-98-Con+inued

[Data for any reporting level include all data reported by States for specified analyte without regard to differences in minimum reporting levels or method detection limits, whereas data for specific censoring levels have been censored to remove samples with a reporting level higher than the specified censoring leveI, and all reported detectable concentrations of the specified analyte below the censoring level have been converted to "less than" values; $\mu \mathrm{g} / \mathrm{L}$, micrograms per liter; CWSs, community water systems]

\begin{tabular}{|c|c|c|c|c|c|c|c|}
\hline \multirow{2}{*}{ Volatile organic compound and statistic } & \multicolumn{7}{|c|}{ Reporting or censoring level } \\
\hline & Any & $20 \mu \mathrm{g} / \mathrm{L}$ & $10 \mu \mathrm{g} / \mathrm{L}$ & $5.0 \mu \mathrm{g} / \mathrm{L}$ & $2.0 \mu \mathrm{g} / \mathrm{L}$ & $1.0 \mu \mathrm{g} / \mathrm{L}$ & $0.5 \mu \mathrm{g} / \mathrm{L}$ \\
\hline \multicolumn{8}{|l|}{ Bromomethane } \\
\hline Number of analyses & 12,733 & 12,733 & 12,733 & 12,730 & 12,729 & 12,729 & 12,179 \\
\hline Percentage of all analyses that include analyte & 58.8 & 58.8 & 58.8 & 58.8 & 58.8 & 58.8 & 56.3 \\
\hline Number of detections & 10 & 0 & 0 & 1 & 4 & 6 & 9 \\
\hline Percentage of analyses with detections & 0.08 & 0 & 0 & 0.01 & 0.03 & 0.05 & 0.07 \\
\hline Number of CWSs with analyses & 1,667 & 1,667 & 1,667 & 1,667 & 1,667 & 1,667 & 1,639 \\
\hline Percentage of all CWSs with analyses & 79.0 & 79.0 & 79.0 & 79.0 & 79.0 & 79.0 & 77.7 \\
\hline Number of CWSs with detections & 9 & 0 & 0 & 1 & 4 & 6 & 9 \\
\hline Percentage of CWSs with detections & 0.5 & 0 & 0 & 0.06 & 0.2 & 0.4 & 0.6 \\
\hline \multicolumn{8}{|l|}{ n-Butylbenzene } \\
\hline Number of analyses & 12,020 & 12,020 & 12,020 & 12,020 & 12,020 & 12,020 & 11,502 \\
\hline Percentage of all analyses that include analyte & 55.6 & 55.6 & 55.6 & 55.6 & 55.6 & 55.6 & 53.2 \\
\hline Number of detections & 22 & 0 & 0 & 2 & 3 & 12 & 20 \\
\hline Percentage of analyses with detections & 0.2 & 0 & 0 & 0.02 & 0.02 & 0.I & 0.2 \\
\hline Number of CWSs with analyses & 1,569 & 1,569 & 1.569 & 1,569 & 1,569 & 1.569 & 1.543 \\
\hline Percentage of all CWSs with analyses & 74.4 & 74.4 & 74.4 & 74.4 & 74.4 & 74.4 & 73.1 \\
\hline Number of CWSs with detections & 6 & 0 & 0 & 2 & 2 & 2 & 4 \\
\hline Percentage of CWSs with detections & 0.4 & 0 & 0 & 0.1 & 0.1 & 0.1 & 0.3 \\
\hline \multicolumn{8}{|l|}{ sec-Butylbenzene } \\
\hline Number of analyses & 11,284 & I 1,284 & 11,284 & 11,284 & 11,284 & 11,284 & 10,766 \\
\hline Percentage of all analyses that include analyte & 52.2 & 52.2 & 52.2 & 52.2 & 52.2 & 52.2 & 49.8 \\
\hline Number of detections & 1 & 0 & 0 & 0 & 0 & 0 & 1 \\
\hline Percentage of analyses with detections & 0.01 & 0 & 0 & 0 & 0 & 0 & 0.01 \\
\hline Number of CWSs with analyses & 1.471 & 1,471 & 1,471 & 1,471 & 1,471 & 1,471 & 1,445 \\
\hline Percentage of all CWSs with analyses & 69.7 & 69.7 & 69.7 & 69.7 & 69.7 & 69.7 & 68.5 \\
\hline Number of CWSs with detections & 1 & 0 & 0 & 0 & 0 & 0 & 1 \\
\hline Percentage of CWSs with detections & 0.07 & 0 & 0 & 0 & 0 & 0 & 0.07 \\
\hline \multicolumn{8}{|l|}{ tert-Butylbenzene } \\
\hline Number of analyses & 11.283 & 11,283 & 11,283 & 11,283 & 11,283 & 11,283 & 10,748 \\
\hline Percentage of all analyses that include analyte & 52.2 & 52.2 & 52.2 & 52.2 & 52.2 & 52.2 & 49.7 \\
\hline Number of detections & 0 & 0 & 0 & 0 & 0 & 0 & 0 \\
\hline Percentage of analyses with detections & 0 & 0 & 0 & 0 & 0 & 0 & 0 \\
\hline Number of CWSs with analyses & 1,470 & 1,470 & 1,470 & 1,470 & 1,470 & $\mathrm{I}, 470$ & I, 444 \\
\hline Percentage of all CWSs with analyses & 69.7 & 69.7 & 69.7 & 69.7 & 69.7 & 69.7 & 68.4 \\
\hline Number of CWSs with detections & 0 & 0 & 0 & 0 & 0 & 0 & 0 \\
\hline Percentage of CWSs with detections & 0 & 0 & 0 & 0 & 0 & 0 & 0 \\
\hline
\end{tabular}


Appendix 3. Frequency of reporting and frequency of detection of volatile organic compounds included in analyses of drinking water for randomly selected community water systems in the study area compared by reporting levels, 1993-98-Continued

[Data for any reporting level include all data reported by States for specified analyte without regard to differences in minimum reporting levels or method detection limits, whereas data for specific censoring leveIs have been censored to remove samples with a reporting level higher than the specified censoring level, and all reported detectable concentrations of the specified analyte below the censoring level have been converted to "less than" values; $\mu \mathrm{g} / \mathrm{L}$, micrograms per liter; CWSs, community water systems]

\begin{tabular}{|c|c|c|c|c|c|c|c|}
\hline \multirow{2}{*}{ Volatile organic compound and statistic } & \multicolumn{7}{|c|}{ Reporting or censoring level } \\
\hline & Any & $20 \mu \mathrm{g} / \mathrm{L}$ & $10 \mu \mathrm{g} / \mathrm{L}$ & $5.0 \mu \mathrm{g} / \mathrm{L}$ & $2.0 \mu \mathrm{g} / \mathrm{L}$ & $1.0 \mu \mathrm{g} / \mathrm{L}$ & $0.5 \mu \mathrm{g} / \mathrm{L}$ \\
\hline \multicolumn{8}{|l|}{ Carbon disulfide } \\
\hline Number of analyses & 233 & 233 & 233 & 233 & 233 & 233 & 233 \\
\hline Percentage of all analyses that include analyte & 1.1 & 1.1 & 1.1 & 1.1 & 1.1 & 1.1 & 1.1 \\
\hline Number of detections & 1 & 0 & 0 & 0 & 0 & 0 & 1 \\
\hline Percentage of analyses with detections & 0.4 & 0 & 0 & 0 & 0 & 0 & 0.4 \\
\hline Number of CWSs with analyses & 103 & 103 & 103 & 103 & 103 & 103 & 103 \\
\hline Percentage of all CWSs with analyses & 4.9 & 4.9 & 4.9 & 4.9 & 4.9 & 4.9 & 4.9 \\
\hline Number of CWSs with detections & 1 & 0 & 0 & 0 & 0 & 0 & 1 \\
\hline Percentage of CWSs with detections & 1.0 & 0 & 0 & 0 & 0 & 0 & 1.0 \\
\hline \multicolumn{8}{|l|}{ Carbon tetrachloride } \\
\hline Number of analyses & 16,068 & 16,068 & 16,068 & 16,068 & 16,067 & 16,067 & 16,054 \\
\hline Percentage of all analyses that include analyte & 74.3 & 74.3 & 74.3 & 74.3 & 74.3 & 74.3 & 74.2 \\
\hline Number of detections & 120 & 0 & 0 & 1 & 15 & 63 & 115 \\
\hline Percentage of analyses with detections & 0.8 & 0 & 0 & 0.01 & 0.09 & 0.4 & 0.7 \\
\hline Number of CWSs with analyses & 2,086 & 2,086 & 2,086 & 2.086 & 2.086 & 2,086 & 2,086 \\
\hline Percentage of all CWSs with analyses & 98.9 & 98.9 & 98.9 & 98.9 & 98.9 & 98.9 & 98.9 \\
\hline Number of CWSs with detections & 32 & 0 & 0 & 1 & 9 & 17 & 29 \\
\hline Percentage of CWSs with detections & 1.5 & 0 & 0 & 0.05 & 0.4 & 0.8 & 1.4 \\
\hline \multicolumn{8}{|l|}{ 1-Chlorobutane } \\
\hline Number of analyses & 24 & 24 & 24 & 24 & 24 & 24 & 24 \\
\hline Percentage of all analyses that include analyte & 0.1 & 0.1 & 0.1 & 0.1 & 0.1 & 0.1 & 0.1 \\
\hline Number of detections & 0 & 0 & 0 & 0 & 0 & 0 & 0 \\
\hline Percentage of analyses with detections & 0 & 0 & 0 & 0 & 0 & 0 & 0 \\
\hline Number of CWSs with analyses & 4 & 4 & 4 & 4 & 4 & 4 & 4 \\
\hline Percentage of all CWSs with analyses & 0.2 & 0.2 & 0.2 & 0.2 & 0.2 & 0.2 & 0.2 \\
\hline Number of CWSs with detections & 0 & 0 & 0 & 0 & 0 & 0 & 0 \\
\hline Percentage of CWSs with detections & 0 & 0 & 0 & 0 & 0 & 0 & 0 \\
\hline \multicolumn{8}{|l|}{ Chlorodibromomethane } \\
\hline Number of analyses & 13.933 & 13.933 & 13.933 & 13,933 & 13,917 & 13,629 & 12.762 \\
\hline Percentage of all analyses that include analyte & 64.4 & 64.4 & 64.4 & 64.4 & 64.3 & 63.0 & 59.0 \\
\hline Number of detections & 1,846 & 13 & 46 & 208 & 804 & 1,312 & 1,794 \\
\hline Percentage of analyses with detections & 13.2 & 0.09 & 0.3 & 1.5 & 5.8 & 9.6 & 14.1 \\
\hline Number of CWSs with analyses & 1,507 & 1,507 & 1.507 & 1,507 & 1,507 & 1,483 & 1,462 \\
\hline Percentage of all CWSs with analyses & 71.4 & 71.4 & 71.4 & 71.4 & 71.4 & 70.3 & 69.3 \\
\hline Number of CWSs with detections & 389 & 4 & 20 & 52 & 162 & 258 & 387 \\
\hline Percentage of CWSs with detections & 25.8 & 0.3 & 1.3 & 3.4 & 10.8 & 17.4 & 26.5 \\
\hline
\end{tabular}


Appendix 3. Frequency of reporting and frequency of detection of volatile organic compounds included in analyses of drinking water for randomly selected community water systems in the study area compared by reporting levels, 1993-98-Con *inued

[Data for any reporting level include all data reported by States for specified analyte without regard to differences in minimum reporting levels o* method detection limits. whereas data for specific censoring levels have been censored to remove samples with a reporting level higher than the specified censoring level, and all reported detectable concentrations of the specified analyte below the censoring level have been converted to "less than" values; $\mu \mathrm{g} / \mathrm{L}$, micrograms per liter: CWSs, community water systems]

\begin{tabular}{|c|c|c|c|c|c|c|c|}
\hline \multirow{2}{*}{ Volatile organic compound and statistic } & \multicolumn{7}{|c|}{ Reporting or censoring level } \\
\hline & Any & $20 \mu \mathrm{g} / \mathrm{L}$ & $10 \mu \mathrm{g} / \mathrm{L}$ & $5.0 \mu \mathrm{g} / \mathrm{L}$ & $2.0 \mu \mathrm{g} / \mathrm{L}$ & $1.0 \mu \mathrm{g} / \mathrm{L}$ & $0.5 \mu \mathrm{g} / \mathrm{L}$ \\
\hline \multicolumn{8}{|l|}{ Chloroethane } \\
\hline Number of analyses & 12.691 & 12,691 & 12,691 & 12,691 & 12,687 & 12,687 & 12.160 \\
\hline Percentage of all analyses that include analyte & 58.7 & 58.7 & 58.7 & 58.7 & 58.6 & 58.6 & 56.2 \\
\hline Number of detections & 10 & 1 & 1 & 1 & 2 & 4 & 10 \\
\hline Percentage of analyses with detections & 0.08 & 0.01 & 0.01 & 0.01 & 0.02 & 0.03 & 0.08 \\
\hline Number of CWSs with analyses & 1,665 & 1,665 & 1,665 & 1,665 & 1,665 & 1,665 & 1,638 \\
\hline Percentage of all CWSs with analyses & 78.9 & 78.9 & 78.9 & 78.9 & 78.9 & 78.9 & 77.6 \\
\hline Number of CWSs with detections & 7 & 1 & 1 & 1 & 2 & 3 & 7 \\
\hline Percentage of CWSs with detections & 0.4 & 0.06 & 0.06 & 0.06 & 0.1 & 0.2 & 0.4 \\
\hline \multicolumn{8}{|l|}{ 2-Chloroethyl vinyl ether } \\
\hline Number of analyses & 59 & 59 & 59 & 59 & 59 & 59 & 59 \\
\hline Percentage of all analyses that include analyte & 0.3 & 0.3 & 0.3 & 0.3 & 0.3 & 0.3 & 0.3 \\
\hline Number of detections & 0 & 0 & 0 & 0 & 0 & 0 & 0 \\
\hline Percentage of analyses with detections & 0 & 0 & 0 & 0 & 0 & 0 & 0 \\
\hline Number of CWSs with analyses & 8 & 8 & 8 & 8 & 8 & 8 & 8 \\
\hline Percentage of all CWSs with analyses & 0.4 & 0.4 & 0.4 & 0.4 & 0.4 & 0.4 & 0.4 \\
\hline Number of CWSs with detections & 0 & 0 & 0 & 0 & 0 & 0 & 0 \\
\hline Percentage of CWSs with detections & 0 & 0 & 0 & 0 & 0 & 0 & 0 \\
\hline \multicolumn{8}{|l|}{ Chloroform } \\
\hline Number of analyses & 14.055 & 14,053 & 14,053 & 14,053 & 14,047 & 14,046 & 13,511 \\
\hline Percentage of all analyses that include analyte & 65.0 & 65.0 & 65.0 & 65.0 & 64.9 & 64.9 & 62.4 \\
\hline Number of detections & 3,802 & 1,605 & 2,130 & 2,443 & 2,880 & 3,261 & 3,726 \\
\hline Percentage of analyses with detections & 27.0 & 11.4 & 15.2 & 17.4 & 20.5 & 23.2 & 27.6 \\
\hline Number of CWSs with analyses & 1,504 & 1,504 & 1,504 & 1,504 & 1,501 & 1,501 & 1,484 \\
\hline Percentage of all CWSs with analyses & 71.3 & 71.3 & 71.3 & 71.3 & 71.1 & 71.1 & 70.3 \\
\hline Number of CWSs with detections & 589 & 195 & 266 & 323 & 420 & 497 & 582 \\
\hline Percentage of CWSs with detections & 39.2 & 13.0 & 17.7 & 21.5 & 28.0 & 33.1 & 39.2 \\
\hline \multicolumn{8}{|l|}{ Chloromethane } \\
\hline Number of analyses & 12,721 & 12,721 & 12,721 & 12,721 & 12,717 & 12,717 & 12,149 \\
\hline Percentage of all analyses that include analyte & 58.8 & 58.8 & 58.8 & 58.8 & 58.8 & 58.8 & 56.2 \\
\hline Number of detections & 39 & 4 & 5 & 8 & 16 & 25 & 39 \\
\hline Percentage of analyses with detections & 0.3 & 0.03 & 0.04 & 0.06 & 0.1 & 0.2 & 0.3 \\
\hline Number of CWSs with analyses & 1,667 & 1.667 & 1,667 & 1,667 & 1,667 & 1,667 & 1.640 \\
\hline Percentage of all CWSs with analyses & 79.0 & 79.0 & 79.0 & 79.0 & 79.0 & 79.0 & 77.7 \\
\hline Number of CWSs with detections & 29 & 4 & 5 & 7 & 12 & 18 & 29 \\
\hline Percentage of CWSs with detections & 1.7 & 0.2 & 0.3 & 0.4 & 0.7 & 1.1 & 1.8 \\
\hline
\end{tabular}


Appendix 3. Frequency of reporting and frequency of detection of volatile organic compounds included in analyses of drinking water for randomly selected community water systems in the study area compared by reporting levels, 1993-98-Continued

[Data for any reporting level include all data reported by States for specified analyte without regard to differences in minimum reporting levels or method detection limits, whereas data for specific censoring levels have been censored to remove samples with a reporting level higher than the specifiad censoring level, and all reported detectable concentrations of the specified analyte below the censoring level have been converted to "less than" values; $\mu \mathrm{g} / \mathrm{L}$, micrograms per liter; CWSs, community water systems]

\begin{tabular}{|c|c|c|c|c|c|c|c|}
\hline \multirow{2}{*}{ Volatile organic compound and statistic } & \multicolumn{7}{|c|}{ Reporting or censoring level } \\
\hline & Any & $20 \mu \mathrm{g} / \mathrm{L}$ & $10 \mu \mathrm{g} / \mathrm{L}$ & $5.0 \mu \mathrm{g} / \mathrm{L}$ & $2.0 \mu \mathrm{g} / \mathrm{L}$ & $1.0 \mu \mathrm{g} / \mathrm{L}$ & $0.5 \mu \mathrm{g} / \mathrm{L}$ \\
\hline \multicolumn{8}{|l|}{ o-Chlorotoluene } \\
\hline Number of analyses & 12.504 & 12,504 & 12,504 & 12,504 & 12,504 & 12,504 & 11,998 \\
\hline Percentage of all analyses that include analyte & 57.8 & 57.8 & 57.8 & 57.8 & 57.8 & 57.8 & 55.5 \\
\hline Number of detections & 3 & 0 & 0 & 0 & 0 & 2 & 2 \\
\hline Percentage of analyses with detections & 0.02 & 0 & 0 & 0 & 0 & 0.02 & 0.02 \\
\hline Number of CWSs with analyses & 1,584 & 1.584 & 1,584 & 1,584 & 1,584 & 1,584 & 1,558 \\
\hline Percentage of all CWSs with analyses & 75.1 & 75.1 & 75.1 & 75.1 & 75.1 & 75.1 & 73.8 \\
\hline Number of CWSs with detections & 2 & 0 & 0 & 0 & 0 & 2 & 2 \\
\hline Percentage of CWSs with detections & 0.1 & 0 & 0 & 0 & 0 & 0.1 & 0.1 \\
\hline \multicolumn{8}{|l|}{ p-Chlorotoluene } \\
\hline Number of analyses & 12,688 & 12,688 & 12,688 & 12,688 & 12,688 & 12,688 & 12,136 \\
\hline Percentage of all analyses that include analyte & 58.6 & 58.6 & 58.6 & 58.6 & 58.6 & 58.6 & 56.1 \\
\hline Number of detections & 5 & 0 & 0 & 0 & 2 & 3 & 5 \\
\hline Percentage of analyses with detections & 0.04 & 0 & 0 & 0 & 0.02 & 0.02 & 0.04 \\
\hline Number of CWSs with analyses & 1,672 & 1.672 & 1,672 & 1,672 & 1.672 & 1,672 & 1,645 \\
\hline Percentage of all CWSs with analyses & 79.2 & 79.2 & 79.2 & 79.2 & 79.2 & 79.2 & 78.0 \\
\hline Number of CWSs with detections & 4 & 0 & 0 & 0 & 2 & 2 & 4 \\
\hline Percentage of CWSs with detections & 0.2 & 0 & 0 & 0 & 0.1 & 0.1 & 0.2 \\
\hline \multicolumn{8}{|l|}{ Dibromochloropropane } \\
\hline Number of analyses & 7,009 & 7,009 & 7,009 & 6,593 & 6,580 & 6,580 & 6,542 \\
\hline Percentage of all analyses that include analyte & 32.4 & 32.4 & 32.4 & 30.5 & 30.4 & 30.4 & 30.2 \\
\hline Number of detections & 29 & 0 & 0 & 0 & 0 & 1 & 2 \\
\hline Percentage of analyses with detections & 0.4 & 0 & 0 & 0 & 0 & 0.01 & 0.03 \\
\hline Number of CWSs with analyses & 1,440 & 1.440 & 1.440 & 1,439 & 1.439 & 1,439 & 1,434 \\
\hline Percentage of all CWSs with analyses & 68.2 & 68.2 & 68.2 & 68.2 & 68.2 & 68.2 & 68.0 \\
\hline Number of CWSs with detections & 25 & 0 & 0 & 0 & 0 & 1 & 2 \\
\hline Percentage of CWSs with detections & 1.7 & 0 & 0 & 0 & 0 & 0.07 & 0.1 \\
\hline \multicolumn{8}{|l|}{ Dibromomethane } \\
\hline Number of analyses & 12.729 & 12,729 & 12,729 & 12,729 & 12,729 & 12,702 & 12,144 \\
\hline Percentage of all analyses that include analyte & 58.8 & 58.8 & 58.8 & 58.8 & 58.8 & 58.7 & 56.1 \\
\hline Number of detections & 18 & 0 & 0 & 1 & 1 & 6 & 17 \\
\hline Percentage of analyses with detections & 0.1 & 0 & 0 & 0.01 & 0.01 & 0.05 & 0.1 \\
\hline Number of CWSs with analyses & 1,667 & 1,667 & 1,667 & 1,667 & 1,667 & 1,667 & 1,639 \\
\hline Percentage of all CWSs with analyses & 79.0 & 79.0 & 79.0 & 79.0 & 79.0 & 79.0 & 77.7 \\
\hline Number of CWSs with detections & 14 & 0 & 0 & 1 & 1 & 5 & 14 \\
\hline Percentage of CWSs with detections & 0.8 & 0 & 0 & 0.06 & 0.06 & 0.3 & 0.8 \\
\hline
\end{tabular}


Appendix 3. Frequency of reporting and frequency of detection of volatile organic compounds included in analyses cf drinking water for randomly selected community water systems in the study area compared by reporting levels, 1993-98-Continued

[Data for any reporting level include all data reported by States for specified analyte without regard to differences in minimum reporting levels o* method detection limits, whereas data for specific censoring levels have been censored to remove samples with a reporting level higher than the specified censoring leveI, and all reported detectable concentrations of the specified analyte below the censoring level have been converted to "less than" values; $\mu \mathrm{g} / \mathrm{L}$, micrograms per liter; CWSs, community water systems]

\begin{tabular}{|c|c|c|c|c|c|c|c|}
\hline \multirow{2}{*}{ Volatile organic compound and statistic } & \multicolumn{7}{|c|}{ Reporting or censoring level } \\
\hline & Any & $20 \mu \mathrm{g} / \mathrm{L}$ & $10 \mu \mathrm{g} / \mathrm{L}$ & $5.0 \mu \mathrm{g} / \mathrm{L}$ & $2.0 \mu \mathrm{g} / \mathrm{L}$ & $1.0 \mu \mathrm{g} / \mathrm{L}$ & $0.5 \mu \mathrm{g} / \mathrm{L}$ \\
\hline \multicolumn{8}{|l|}{ m-Dichlorobenzene } \\
\hline Percentage of all analyses that include analyte & 58.9 & 58.9 & 58.9 & 58.9 & 58.9 & 58.9 & 56.4 \\
\hline Number of detections & 0 & 0 & 0 & 0 & 0 & 0 & 0 \\
\hline Number of CWSs with analyses & 1.674 & 1,674 & 1,674 & 1.674 & 1,674 & 1,674 & 1,648 \\
\hline Percentage of all CWSs with analyses & 79.3 & 79.3 & 79.3 & 79.3 & 79.3 & 79.3 & 78.1 \\
\hline Number of CWSs with detections & 0 & 0 & 0 & 0 & 0 & 0 & 0 \\
\hline Percentage of CWSs with detections & 0 & 0 & 0 & 0 & 0 & 0 & 0 \\
\hline Number of detections & 16 & 7 & 7 & 7 & 8 & 11 & 15 \\
\hline Percentage of analyses with detections & 0.1 & 0.04 & 0.04 & 0.04 & 0.05 & 0.07 & 0.1 \\
\hline Number of CWSs with analyses & 2,096 & 2,096 & 2,096 & 2.096 & 2,096 & 2,096 & 2,096 \\
\hline Percentage of all CWSs with analyses & 99.3 & 99.3 & 99.3 & 99.3 & 99.3 & 99.3 & 99.3 \\
\hline Number of CWSs with detections & 8 & 1 & 1 & 1 & 2 & 5 & 7 \\
\hline Percentage of CWSs with detections & 0.4 & 0.05 & 0.05 & 0.05 & 0.1 & 0.2 & 0.3 \\
\hline \multicolumn{8}{|l|}{$p$-Dichlorobenzene } \\
\hline Number of analyses & 15.914 & 15.914 & 15.914 & 15,913 & 15,913 & 15.913 & 15,895 \\
\hline Percentage of CWSs with detections & 0.9 & 0 & 0 & 0 & 0.1 & 0.4 & 0.8 \\
\hline \multicolumn{8}{|l|}{ Dichlorobenzenes, total } \\
\hline Number of analyses & 124 & 124 & 124 & 124 & 124 & 124 & 124 \\
\hline Percentage of all analyses that include analyte & 0.6 & 0.6 & 0.6 & 0.6 & 0.6 & 0.6 & 0.6 \\
\hline Number of detections & 0 & 0 & 0 & 0 & 0 & 0 & 0 \\
\hline Percentage of analyses with detections & 0 & 0 & 0 & 0 & 0 & 0 & 0 \\
\hline Number of CWSs with analyses & 27 & 27 & 27 & 27 & 27 & 27 & 27 \\
\hline Percentage of all CWSs with analyses & 1.3 & 1.3 & 1.3 & 1.3 & 1.3 & 1.3 & 1.3 \\
\hline Number of CWSs with detections & 0 & 0 & 0 & 0 & 0 & 0 & 0 \\
\hline Percentage of CWSs with detections & 0 & 0 & 0 & 0 & 0 & 0 & 0 \\
\hline
\end{tabular}


Appendix 3. Frequency of reporting and frequency of detection of volatile organic compounds included in analyses of drinking water for randomly selected community water systems in the study area compared by reporting levels, 1993-98-Continued

[Data for any reporting level include all data reported by States for specified analyte without regard to differences in minimum reporting Ievels or method detection limits, whereas data for specific censoring levels have been censored to remove samples with a reporting level higher than the specified censoring level, and all reported detectable concentrations of the specified analyte below the censoring leveI have been converted to "less than" values; $\mu \mathrm{g} / \mathrm{L}$, micrograms per liter; CWSs, community water systems]

\begin{tabular}{|c|c|c|c|c|c|c|c|}
\hline \multirow{2}{*}{ Volatile organic compound and statistic } & \multicolumn{7}{|c|}{ Reporting or censoring level } \\
\hline & Any & $20 \mu \mathrm{g} / \mathrm{L}$ & $10 \mu \mathrm{g} / \mathrm{L}$ & $5.0 \mu \mathrm{g} / \mathrm{L}$ & $2.0 \mu \mathrm{g} / \mathrm{L}$ & $1.0 \mu \mathrm{g} / \mathrm{L}$ & $0.5 \mu \mathrm{g} / \mathrm{L}$ \\
\hline \multicolumn{8}{|l|}{ Dichlorobenzenes, calculated } \\
\hline Number of analyses & 16,091 & 16,091 & 16.091 & 16.090 & 16,090 & 16,090 & 15,565 \\
\hline Percentage of all analyses that include analyte & 74.4 & 74.4 & 74.4 & 74.4 & 74.4 & 74.4 & 71.9 \\
\hline Number of detections & 51 & 7 & 7 & 7 & 13 & 28 & 48 \\
\hline Percentage of analyses with detections & 0.3 & 0.04 & 0.04 & 0.04 & 0.08 & 0.2 & 0.3 \\
\hline Number of CWSs with analyses & 2,096 & 2,096 & 2,096 & 2,096 & 2,096 & 2,096 & 2,070 \\
\hline Percentage of all CWSs with analyses & 99.3 & 99.3 & 99.3 & 99.3 & 99.3 & 99.3 & 98.1 \\
\hline Number of CWSs with detections & 25 & 1 & 1 & 1 & 5 & 14 & 24 \\
\hline Percentage of CWSs with detections & 1.2 & 0.05 & 0.05 & 0.05 & 0.2 & 0.7 & 1.2 \\
\hline \multicolumn{8}{|l|}{ Dichlorodifluoromethane } \\
\hline Number of analyses & 12,147 & 12,147 & 12,147 & 12,147 & 12,147 & 12,124 & 11,569 \\
\hline Percentage of all analyses that include analyte & 56.2 & 56.2 & 56.2 & 56.2 & 56.2 & 56.0 & 53.5 \\
\hline Number of detections & 202 & 1 & 23 & 38 & 72 & 144 & 202 \\
\hline Percentage of analyses with detections & 1.7 & 0.01 & 0.2 & 0.3 & 0.6 & 1.2 & 1.8 \\
\hline Number of CWSs with analyses & 1,628 & 1.628 & 1,628 & 1,628 & 1,628 & 1,628 & 1,601 \\
\hline Percentage of all CWSs with analyses & 77.2 & 77.2 & 77.2 & 77.2 & 77.2 & 77.2 & 75.9 \\
\hline Number of CWSs with detections & 20 & 1 & 3 & 4 & 8 & 16 & 20 \\
\hline Percentage of CWSs with detections & 1.2 & 0.06 & 0.2 & 0.2 & 0.5 & 1.0 & 1.2 \\
\hline \multicolumn{8}{|l|}{ 1,1-Dichloroethane } \\
\hline Number of analyses & 12,786 & 12,786 & 12,786 & 12,786 & 12,785 & 12,785 & 12,273 \\
\hline Percentage of all analyses that include analyte & 59.1 & 59.1 & 59.1 & 59.1 & 59.1 & 59.1 & 56.7 \\
\hline Number of detections & 440 & 1 & 6 & 34 & 178 & 308 & 420 \\
\hline Percentage of analyses with detections & 3.4 & 0.01 & 0.05 & 0.3 & 1.4 & 2.4 & 3.4 \\
\hline Number of CWSs with analyses & 1,666 & 1,666 & 1,666 & 1,666 & 1,666 & 1,666 & 1,641 \\
\hline Percentage of all CWSs with analyses & 79.0 & 79.0 & 79.0 & 79.0 & 79.0 & 79.0 & 77.8 \\
\hline Number of CWSs with detections & 31 & 1 & 4 & 5 & 15 & 22 & 30 \\
\hline Percentage of CWSs with detections & 1.9 & 0.06 & 0.2 & 0.3 & 0.9 & 1.3 & 1.8 \\
\hline \multicolumn{8}{|l|}{ 1,2-Dichloroethane } \\
\hline Number of analyses & 16,090 & 16.090 & 16,090 & 16,090 & 16,089 & 16,089 & 16,076 \\
\hline Percentage of all analyses that include analyte & 74.4 & 74.4 & 74.4 & 74.4 & 74.4 & 74.4 & 74.3 \\
\hline Number of detections & 119 & 0 & 0 & 3 & 12 & 28 & 112 \\
\hline Percentage of analyses with detections & 0.7 & 0 & 0 & 0.02 & 0.07 & 0.2 & 0.7 \\
\hline Number of CWSs with analyses & 2,088 & 2,088 & 2,088 & 2,088 & 2,088 & 2,088 & 2,088 \\
\hline Percentage of all CWSs with analyses & 99.0 & 99.0 & 99.0 & 99.0 & 99.0 & 99.0 & 99.0 \\
\hline Number of CWSs with detections & 39 & 0 & 0 & 2 & 6 & 15 & 37 \\
\hline Percentage of CWSs with detections & 1.9 & 0 & 0 & 0.1 & 0.3 & 0.7 & 1.8 \\
\hline
\end{tabular}


Appendix 3. Frequency of reporting and frequency of detection of volatile organic compounds included in analyses of drinking water for randomly selected community water systems in the study area compared by reporting levels, 1993-98-Continued

[Data for any reporting level include all data reported by States for specified analyte without regard to differences in minimum reporting levels cr method detection limits, whereas data for specific censoring levels have been censored to remove samples with a reporting level higher than the specified censoring level, and all reported detectable concentrations of the specified analyte below the censoring level have been converted to "less than" values; $\mu \mathrm{g} / \mathrm{L}$, micrograms per liter: CWSs, community water systems]

\begin{tabular}{|c|c|c|c|c|c|c|c|}
\hline \multirow{2}{*}{ Volatile organic compound and statistic } & \multicolumn{7}{|c|}{ Reporting or censoring level } \\
\hline & Any & $20 \mu \mathrm{g} / \mathrm{L}$ & $10 \mu \mathrm{g} / \mathrm{L}$ & $5.0 \mu \mathrm{g} / \mathrm{L}$ & $2.0 \mu \mathrm{g} / \mathrm{L}$ & $1.0 \mu \mathrm{g} / \mathrm{L}$ & $0.5 \mu \mathrm{g} / \mathrm{L}$ \\
\hline \multicolumn{8}{|l|}{ 1,1-Dichloroethene } \\
\hline Number of analyses & 15.357 & 15,357 & 15.357 & 15.357 & 15,356 & 15,356 & 15,343 \\
\hline Percentage of all analyses that include analyte & 71.0 & 71.0 & 71.0 & 71.0 & 71.0 & 71.0 & 70.9 \\
\hline Number of detections & 428 & 46 & 73 & 110 & 192 & 281 & 422 \\
\hline Percentage of analyses with detections & 2.8 & 0.3 & 0.5 & 0.7 & 1.2 & 1.8 & 2.8 \\
\hline Number of CWSs with analyses & 1,785 & 1.785 & 1.785 & 1,785 & 1,785 & 1.785 & 1,785 \\
\hline Percentage of all CWSs with analyses & 84.6 & 84.6 & 84.6 & 84.6 & 84.6 & 84.6 & 84.6 \\
\hline Number of CWSs with detections & 34 & 4 & 5 & 9 & 15 & 23 & 34 \\
\hline Percentage of CWSs with detections & 1.9 & 0.2 & 0.3 & 0.5 & 0.8 & 1.3 & 1.9 \\
\hline \multicolumn{8}{|l|}{ cis-1,2-Dichloroethene } \\
\hline Number of analyses & 16,017 & 16.017 & 16,017 & 16,017 & 16,017 & 16,017 & 15,783 \\
\hline Percentage of all analyses that include analyte & 74.0 & 74.0 & 74.0 & 74.0 & 74.0 & 74.0 & 73.0 \\
\hline Number of detections & 672 & 45 & 70 & 180 & 350 & 474 & 655 \\
\hline Percentage of analyses with detections & 4.2 & 0.3 & 0.4 & 1.1 & 2.2 & 3.0 & 4.2 \\
\hline Number of CWSs with analyses & 2,089 & 2.089 & 2,089 & 2,089 & 2,089 & 2,089 & 2,089 \\
\hline Percentage of all CWSs with analyses & 99.0 & 99.0 & 99.0 & 99.0 & 99.0 & 99.0 & 99.0 \\
\hline Number of CWSs with detections & 43 & 5 & 11 & 15 & 25 & 36 & 42 \\
\hline Percentage of CWSs with detections & 2.1 & 0.2 & 0.5 & 0.7 & 1.2 & 1.7 & 2.0 \\
\hline \multicolumn{8}{|l|}{ trans-1,2-Dichloroethene } \\
\hline Number of analyses & 16,046 & 16,046 & 16,046 & 16.046 & 16,045 & 16,045 & 15,810 \\
\hline Percentage of all analyses that include analyte & 74.2 & 74.2 & 74.2 & 74.2 & 74.2 & 74.2 & 73.1 \\
\hline Number of detections & 27 & 1 & 2 & 4 & 10 & 17 & 27 \\
\hline Percentage of analyses with detections & 0.2 & 0.01 & 0.01 & 0.02 & 0.06 & 0.1 & 0.2 \\
\hline Number of CWSs with analyses & 2,090 & 2,090 & 2,090 & 2,090 & 2,090 & 2,090 & 2,090 \\
\hline Percentage of all CWSs with analyses & 99.0 & 99.0 & 99.0 & 99.0 & 99.0 & 99.0 & 99.0 \\
\hline Number of CWSs with detections & 13 & 1 & 1 & 2 & 4 & 7 & 13 \\
\hline Percentage of CWSs with detections & 0.6 & 0.05 & 0.05 & 0.1 & 0.2 & 0.3 & 0.6 \\
\hline \multicolumn{8}{|l|}{ Dichloromethane } \\
\hline Number of analyses & 16,015 & 16,015 & 16,015 & 16,015 & 16,014 & 16,014 & 15,768 \\
\hline Percentage of all analyses that include analyte & 74.0 & 74.0 & 74.0 & 74.0 & 74.0 & 74.0 & 72.9 \\
\hline Number of detections & 118 & 1 & 2 & 11 & 25 & 62 & 115 \\
\hline Percentage of analyses with detections & 0.7 & 0.01 & 0.01 & 0.07 & 0.2 & 0.4 & 0.7 \\
\hline Number of CWSs with analyses & 2,088 & 2,088 & 2,088 & 2,088 & 2,088 & 2,088 & 2,088 \\
\hline Percentage of all CWSs with analyses & 99.0 & 99.0 & 99.0 & 99.0 & 99.0 & 99.0 & 99.0 \\
\hline Number of CWSs with detections & 60 & 1 & 2 & 8 & 17 & 35 & 58 \\
\hline Percentage of CWSs with detections & 2.9 & 0.05 & 0.1 & 0.4 & 0.8 & 1.7 & 2.8 \\
\hline
\end{tabular}


Appendix 3. Frequency of reporting and frequency of detection of volatile organic compounds included in analyses of drinking water for randomly selected community water systems in the study area compared by reporting levels, 1993-98-Continued

[Data for any reporting level include all data reported by States for specified analyte without regard to differences in minimum reporting levels or method detection limits, whereas data for specific censoring levels have been censored to remove samples with a reporting level higher than the specified censoring level, and all reported detectable concentrations of the specified analyte below the censoring level have been converted to "less than" values; $\mu \xi / L$, micrograms per liter; CWSs, community water systems]

\begin{tabular}{|c|c|c|c|c|c|c|c|}
\hline \multirow{2}{*}{ Volatile organic compound and statistic } & \multicolumn{7}{|c|}{ Reporting or censoring level } \\
\hline & Any & $20 \mu g / L$ & $10 \mu \mathrm{g} / \mathrm{L}$ & $5.0 \mu \mathrm{g} / \mathrm{L}$ & $2.0 \mu \mathrm{g} / \mathrm{L}$ & $1.0 \mu \mathrm{g} / \mathrm{L}$ & $0.5 \mu \mathrm{g} / \mathrm{L}$ \\
\hline \multicolumn{8}{|l|}{ 1,2-Dichloropropane } \\
\hline Percentage of all analyses that include analyte & 73.3 & 73.3 & 73.3 & 73.3 & 73.3 & 73.3 & 72.2 \\
\hline Number of detections & 83 & 1 & 1 & 11 & 22 & 48 & 81 \\
\hline Number of CWSs with analyses & 2,087 & 2,087 & 2,087 & 2,087 & 2,087 & 2,087 & 2,087 \\
\hline Percentage of all CWSs with analyses & 98.9 & 98.9 & 98.9 & 98.9 & 98.9 & 98.9 & 98.9 \\
\hline Number of CWSs with detections & 15 & 1 & 1 & 3 & 6 & 11 & 15 \\
\hline Percentage of CWSs with detections & 0.7 & 0.05 & 0.05 & 0.1 & 0.3 & 0.5 & 0.7 \\
\hline Number of detections & 10 & 0 & 0 & 2 & 3 & 6 & 9 \\
\hline Percentage of analyses with detections & 0.08 & 0 & 0 & 0.02 & 0.02 & 0.05 & 0.07 \\
\hline Number of CWSs with analyses & 1,665 & 1,665 & 1,665 & 1,665 & 1,665 & 1,665 & 1,640 \\
\hline Percentage of all CWSs with analyses & 78.9 & 78.9 & 78.9 & 78.9 & 78.9 & 78.9 & 77.7 \\
\hline Number of CWSs with detections & 5 & 0 & 0 & 1 & 1 & 3 & 5 \\
\hline Percentage of CWSs with detections & 0.3 & 0 & 0 & 0.06 & 0.06 & 0.2 & 0.3 \\
\hline \multicolumn{8}{|l|}{ 2,2-Dichloropropane } \\
\hline Number of analyses & 12.689 & 12,689 & 12,689 & 12.689 & 12,677 & 12,677 & 12,122 \\
\hline Percentage of all analyses that include analyte & 58.6 & 58.6 & 58.6 & 58.6 & 58.6 & 58.6 & 56.0 \\
\hline Percentage of CWSs with detections & 0.2 & 0 & 0 & 0 & 0.1 & 0.1 & 0.2 \\
\hline \multicolumn{8}{|l|}{ 1,1-Dichloropropene } \\
\hline Number of analyses & 12,713 & 12,713 & 12,713 & 12,713 & 12,713 & 12,701 & 12,173 \\
\hline Percentage of all analyses that include analyte & 58.8 & 58.8 & 58.8 & 58.8 & 58.8 & 58.7 & 56.3 \\
\hline Number of detections & 0 & 0 & 0 & 0 & 0 & 0 & 0 \\
\hline Percentage of analyses with detections & 0 & 0 & 0 & 0 & 0 & 0 & 0 \\
\hline Number of CWSs with analyses & 1,665 & 1,665 & 1,665 & 1,665 & 1,665 & 1,665 & 1,639 \\
\hline Percentage of all CWSs with analyses & 78.9 & 78.9 & 78.9 & 78.9 & 78.9 & 78.9 & 77.7 \\
\hline Number of CWSs with detections & 0 & 0 & 0 & 0 & 0 & 0 & 0 \\
\hline Percentage of CWSs with detections & 0 & 0 & 0 & 0 & 0 & 0 & 0 \\
\hline
\end{tabular}


Appendix 3. Frequency of reporting and frequency of detection of volatile organic compounds included in analyses of drinking water for randomly selected community water systems in the study area compared by reporting levels, 1993-98-Con+inued

[Data for any reporting level include aII data reported by States for specified analyte without regard to differences in minimum reporting levels or method detection limits, whereas data for specific censoring leveIs have been censored to remove samples with a reporting Ievel higher than the specified censoring level, and all reported detectable concentrations of the specified analyte below the censoring Ievel have been converted to "Iess than" values; $\mu \mathrm{g} / \mathrm{L}$, micrograms per liter; CWSs, community water systems]

\begin{tabular}{|c|c|c|c|c|c|c|c|}
\hline \multirow{2}{*}{ Volatile organic compound and statistic } & \multicolumn{7}{|c|}{ Reporting or censoring level } \\
\hline & Any & $20 \mu \mathrm{g} / \mathrm{L}$ & $10 \mu \mathrm{g} / \mathrm{L}$ & $5.0 \mu \mathrm{g} / \mathrm{L}$ & $2.0 \mu \mathrm{g} / \mathrm{L}$ & $1.0 \mu \mathrm{g} / \mathrm{L}$ & $0.5 \mu \mathrm{g} / \mathrm{L}$ \\
\hline \multicolumn{8}{|l|}{ cis-1,3-Dichloropropene } \\
\hline Number of analyses & 8,755 & 8,755 & 8.755 & 8,755 & 8.755 & 8.754 & 8,732 \\
\hline Percentage of all analyses that include analyte & 40.5 & 40.5 & 40.5 & 40.5 & 40.5 & 40.5 & 40.4 \\
\hline Number of detections & 1 & 0 & 0 & 0 & 0 & 0 & 1 \\
\hline Percentage of analyses with detections & 0.01 & 0 & 0 & 0 & 0 & 0 & 0.01 \\
\hline Number of CWSs with analyses & 1.078 & 1.078 & 1.078 & 1.078 & 1,078 & 1,078 & 1.078 \\
\hline Percentage of all CWSs with analyses & 51.1 & 51.1 & 51.1 & 51.1 & 51.1 & 51.1 & 51.1 \\
\hline Number of CWSs with detections & l & 0 & 0 & 0 & 0 & 0 & 1 \\
\hline Percentage of CWSs with detections & 0.01 & 0 & 0 & 0 & 0 & 0 & 0.01 \\
\hline \multicolumn{8}{|l|}{ trans-1,3-Dichloropropene } \\
\hline Number of analyses & 8.757 & 8.757 & 8.757 & 8.757 & 8,757 & 8,756 & 8.731 \\
\hline Percentage of all analyses that include analyte & 40.5 & 40.5 & 40.5 & 40.5 & 40.5 & 40.5 & 40.4 \\
\hline Number of detections & 0 & 0 & 0 & 0 & 0 & 0 & 0 \\
\hline Percentage of analyses with detections & 0 & 0 & 0 & 0 & 0 & 0 & 0 \\
\hline Number of CWSs with analyses & 1,078 & 1,078 & 1,078 & 1,078 & 1,078 & 1,078 & 1,078 \\
\hline Percentage of all CWSs with analyses & 51.1 & 51.1 & 51.1 & 51.1 & 51.1 & 51.1 & 51.1 \\
\hline Number of CWSs with detections & 0 & 0 & 0 & 0 & 0 & 0 & 0 \\
\hline Percentage of CWSs with detections & 0 & 0 & 0 & 0 & 0 & 0 & 0 \\
\hline \multicolumn{8}{|l|}{ 1,3-Dichloropropene, cis- \& trans- } \\
\hline Number of analyses & 3,498 & 3,498 & 3,498 & 3,498 & 3,498 & 3,498 & 2,993 \\
\hline Percentage of all analyses that include analyte & 16.2 & 16.2 & 16.2 & 16.2 & 16.2 & 16.2 & 13.8 \\
\hline Number of detections & 0 & 0 & 0 & 0 & 0 & 0 & 0 \\
\hline Percentage of analyses with detections & 0 & 0 & 0 & 0 & 0 & 0 & 0 \\
\hline Number of CWSs with analyses & 463 & 463 & 463 & 463 & 463 & 463 & 437 \\
\hline Percentage of all CWSs with analyses & 21.9 & 21.9 & 21.9 & 21.9 & 21.9 & 21.9 & 20.7 \\
\hline Number of CWSs with detections & 0 & 0 & 0 & 0 & 0 & 0 & 0 \\
\hline Percentage of CWSs with detections & 0 & 0 & 0 & 0 & 0 & 0 & 0 \\
\hline \multicolumn{8}{|l|}{ 1,3-Dichloropropene, calculated } \\
\hline Number of analyses & 12,256 & 12,256 & 12,256 & 12,256 & 12,256 & 12,255 & 11.725 \\
\hline Percentage of all analyses that include analyte & 56.6 & 56.6 & 56.6 & 56.6 & 56.6 & 56.6 & 54.2 \\
\hline Number of detections & 1 & 0 & 0 & 0 & 0 & 0 & 1 \\
\hline Percentage of analyses with detections & 0.01 & 0 & 0 & 0 & 0 & 0 & 0.01 \\
\hline Number of CWSs with analyses & 1,514 & 1,514 & 1,514 & 1,514 & 1,514 & 1.514 & 1.488 \\
\hline Percentage of all CWSs with analyses & 71.8 & 71.8 & 71.8 & 71.8 & 71.8 & 71.8 & 70.5 \\
\hline Number of CWSs with detections & 1 & 0 & 0 & 0 & 0 & 0 & 1 \\
\hline Percentage of CWSs with detections & 0.07 & 0 & 0 & 0 & 0 & 0 & 0.07 \\
\hline
\end{tabular}


Appendix 3. Frequency of reporting and frequency of detection of volatile organic compounds included in analyses of drinking water for randomly selected community water systems in the study area compared by reporting levels, 1993-98-Continued

[Data for any reporting level include all data reported by States for specified analyte without regard to differences in minimum reporting levels or method detection limits, whereas data for specific censoring levels have been censored to remove samples with a reporting level higher than the specified censoring level, and all reported detectable concentrations of the specified analyte below the censoring level have been converted to "less than" values; $\mu \mathrm{g} / \mathrm{L}$, micrograms per liter; CWSs, community water systems]

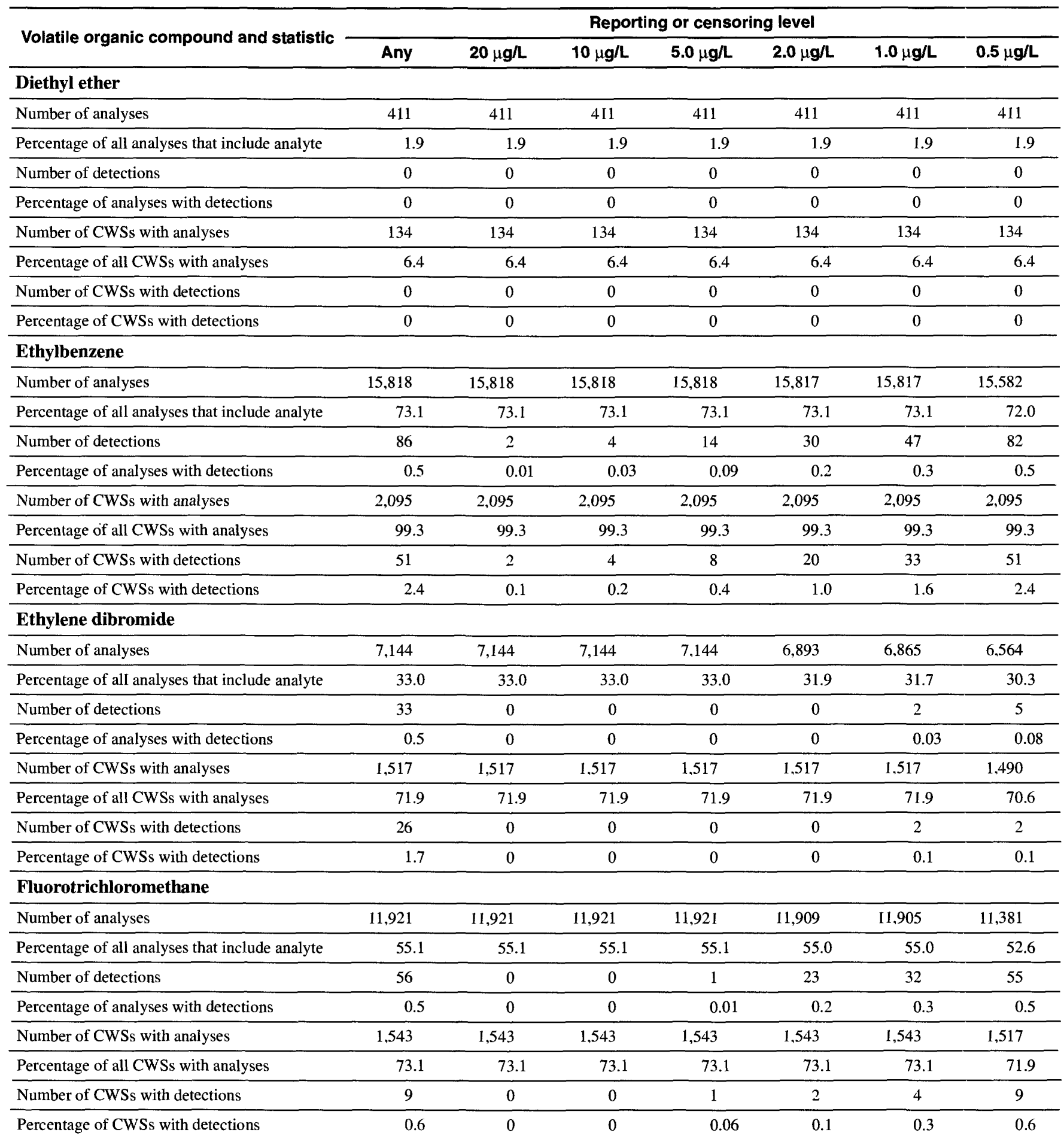


Appendix 3. Frequency of reporting and frequency of detection of volatile organic compounds included in analyses of drinking water for randomly selected community water systems in the study area compared by reporting levels, 1993-98-Continued

[Data for any reporting level include all data reported by States for specified analyte without regard to differences in minimum reporting levels cr method detection limits, whereas data for specific censoring levels have been censored to remove samples with a reporting level higher than the specified censoring level, and all reported detectable concentrations of the specifjed analyte below the censoring level have been converted to "less than" values; $\mu \mathrm{g}, \mathrm{L}$, micrograms per liter; CWSs, community water systems]

\begin{tabular}{|c|c|c|c|c|c|c|c|}
\hline \multirow{2}{*}{ Volatile organic compound and statistic } & \multicolumn{7}{|c|}{ Reporting or censoring level } \\
\hline & Any & $20 \mu \mathrm{g} / \mathrm{L}$ & $10 \mu \mathrm{g} / \mathrm{L}$ & $5.0 \mu \mathrm{g} / \mathrm{L}$ & $2.0 \mu \mathrm{g} / \mathrm{L}$ & $1.0 \mu \mathrm{g} / \mathrm{L}$ & $0.5 \mu \mathrm{g} / \mathrm{L}$ \\
\hline \multicolumn{8}{|l|}{ Hexachlorobutadiene } \\
\hline Number of analyses & 10,584 & 10.584 & 10,584 & 10.583 & 10,583 & 10,583 & 10.062 \\
\hline Percentage of all analyses that include analyte & 48.9 & 48.9 & 48.9 & 48.9 & 48.9 & 48.9 & 46.5 \\
\hline Number of detections & 2 & 0 & 0 & 0 & 0 & 1 & 2 \\
\hline Percentage of analyses with detections & 0.02 & 0 & 0 & 0 & 0 & 0.01 & 0.02 \\
\hline Number of CWSs with analyses & 1.167 & 1.167 & 1,167 & 1,167 & 1,167 & 1,167 & 1,141 \\
\hline Percentage of all CWSs with analyses & 55.3 & 55.3 & 55.3 & 55.3 & 55.3 & 55.3 & 54.1 \\
\hline Number of CWSs with detections & 2 & 0 & 0 & 0 & 0 & 1 & 2 \\
\hline Percentage of CWSs with detections & 0.2 & 0 & 0 & 0 & 0 & 0.09 & 0.2 \\
\hline \multicolumn{8}{|l|}{ Hexachloroethane } \\
\hline Number of analyses & 24 & 24 & 24 & 24 & 24 & 24 & 24 \\
\hline Percentage of all analyses that include analyte & 0.1 & 0.1 & 0.1 & 0.1 & 0.1 & 0.1 & 0.1 \\
\hline Number of detections & 0 & 0 & 0 & 0 & 0 & 0 & 0 \\
\hline Percentage of analyses with detections & 0 & 0 & 0 & 0 & 0 & 0 & 0 \\
\hline Number of CWSs with analyses & 4 & 4 & 4 & 4 & 4 & 4 & 4 \\
\hline Percentage of all CWSs with analyses & 0.2 & 0.2 & 0.2 & 0.2 & 0.2 & 0.2 & 0.2 \\
\hline Number of CWSs with detections & 0 & 0 & 0 & 0 & 0 & 0 & 0 \\
\hline Percentage of CWSs with detections & 0 & 0 & 0 & 0 & 0 & 0 & 0 \\
\hline \multicolumn{8}{|l|}{ n-Hexane } \\
\hline Number of analyses & 83 & 83 & 83 & 83 & 83 & 83 & 70 \\
\hline Percentage of all analyses that include analyte & 0.4 & 0.4 & 0.4 & 0.4 & 0.4 & 0.4 & 0.3 \\
\hline Number of detections & 0 & 0 & 0 & 0 & 0 & 0 & 0 \\
\hline Percentage of analyses with detections & 0 & 0 & 0 & 0 & 0 & 0 & 0 \\
\hline Number of CWSs with analyses & 13 & 13 & 13 & 13 & 13 & 13 & 11 \\
\hline Percentage of all CWSs with analyses & 0.6 & 0.6 & 0.6 & 0.6 & 0.6 & 0.6 & 0.5 \\
\hline Number of CWSs with detections & 0 & 0 & 0 & 0 & 0 & 0 & 0 \\
\hline Percentage of CWSs with detections & 0 & 0 & 0 & 0 & 0 & 0 & 0 \\
\hline \multicolumn{8}{|l|}{ Isopropylbenzene } \\
\hline Number of analyses & 11,853 & 11,853 & 11,853 & 11.853 & 11,853 & 11,853 & 11.335 \\
\hline Percentage of all analyses that include analyte & 54.8 & 54.8 & 54.8 & 54.8 & 54.8 & 54.8 & 52.4 \\
\hline Number of detections & 1 & 0 & 0 & 0 & 0 & 1 & 1 \\
\hline Percentage of analyses with detections & 0.01 & 0 & 0 & 0 & 0 & 0.01 & 0.01 \\
\hline Number of CWSs with analyses & 1,546 & 1,546 & 1,546 & 1.546 & 1.546 & 1,546 & 1,520 \\
\hline Percentage of all CWSs with analyses & 73.3 & 73.3 & 73.3 & 73.3 & 73.3 & 73.3 & 72.0 \\
\hline Number of CWSs with detections & 1 & 0 & 0 & 0 & 0 & 1 & 1 \\
\hline Percentage of CWSs with detections & 0.06 & 0 & 0 & 0 & 0 & 0.06 & 0.07 \\
\hline
\end{tabular}


Appendix 3. Frequency of reporting and frequency of detection of volatile organic compounds included in analyses of drinking water for randomly selected community water systems in the study area compared by reporting levels, 1993-98-Continued

[Data for any reporting level include all data reported by States for specified analyte without regard to differences in minimum reporting levels or method detection limits, whereas data for specific censoring levels have been censored to remove samples with a reporting level higher than the specified censoring level, and all reported detectable concentrations of the specified analyte below the censoring level have been converted to "less than" values; $\mu \mathrm{g} / \mathrm{L}$, micrograms per liter; CWSs, community water systems]

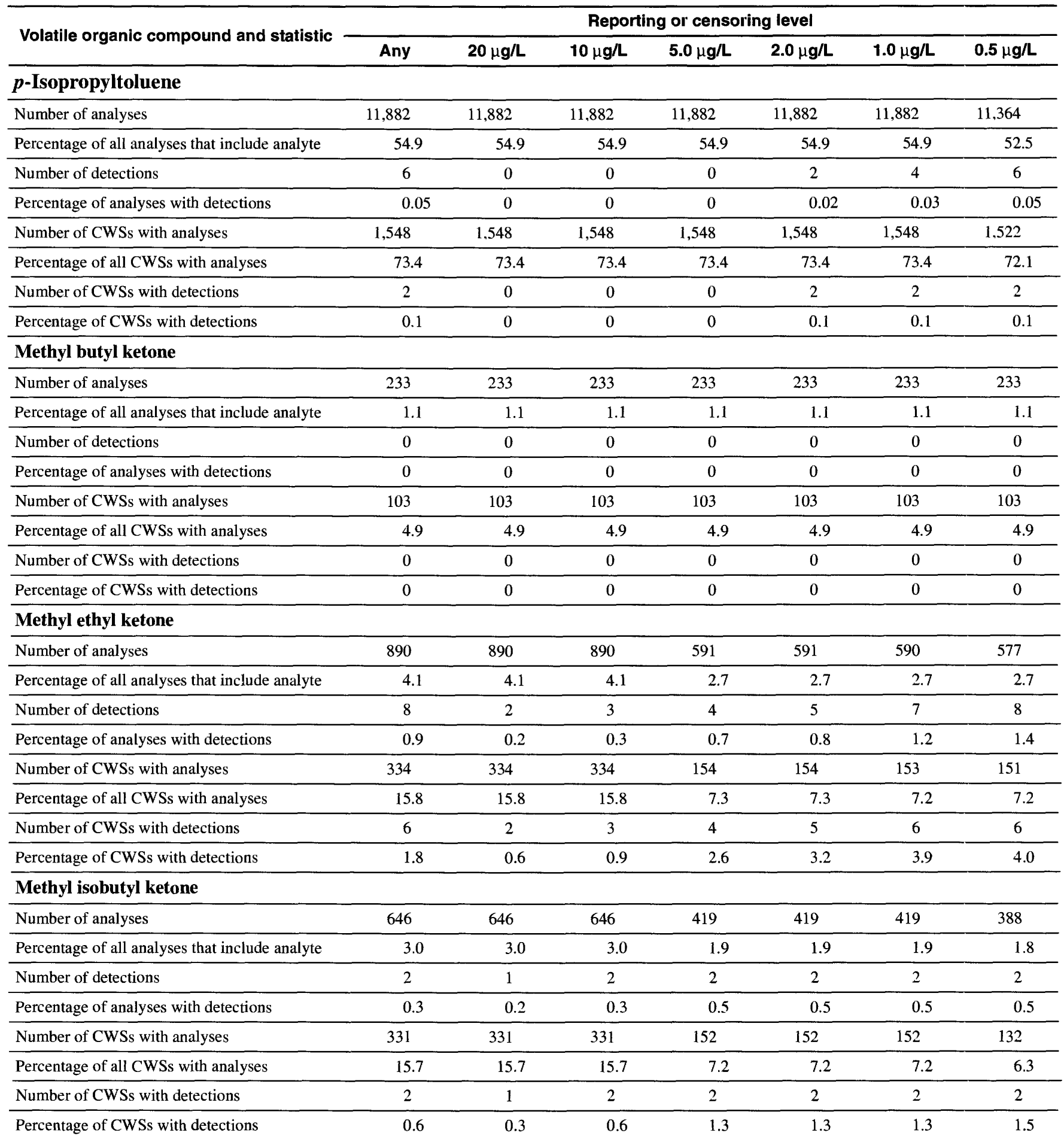


Appendix 3. Frequency of reporting and frequency of detection of volatile organic compounds included in analyses of drinking water for randomly selected community water systems in the study area compared by reporting levels, 1993-98-Con+inued

[Data for any reporting level include all data reported by States for specified analyte without regard to differences in minimum reporting levels or method detection limits, whereas data for specific censoring levels have been censored to remove samples with a reporting level higher than the specified censoring level, and all reported detectable concentrations of the specified analyte below the censoring level have been converted to "less than" values; $\mu \mathrm{g} / \mathrm{L}$, micrograms per liter; CWSs, community water systems]

\begin{tabular}{|c|c|c|c|c|c|c|c|}
\hline \multirow{2}{*}{ Volatile organic compound and statistic } & \multicolumn{7}{|c|}{ Reporting or censoring level } \\
\hline & Any & $20 \mu \mathrm{g} / \mathrm{L}$ & $10 \mu \mathrm{g} / \mathrm{L}$ & $5.0 \mu \mathrm{g} / \mathrm{L}$ & $2.0 \mu \mathrm{g} / \mathrm{L}$ & $1.0 \mu \mathrm{g} / \mathrm{L}$ & $0.5 \mu \mathrm{g} / \mathrm{L}$ \\
\hline \multicolumn{8}{|l|}{ Methyl methacrylate } \\
\hline Number of analyses & 24 & 24 & 24 & 24 & 24 & 24 & 24 \\
\hline Percentage of all analyses that include analyte & 0.1 & 0.1 & 0.1 & 0.1 & 0.1 & 0.1 & 0.1 \\
\hline Number of detections & 0 & 0 & 0 & 0 & 0 & 0 & 0 \\
\hline Percentage of analyses with detections & 0 & 0 & 0 & 0 & 0 & 0 & 0 \\
\hline Number of CWSs with analyses & 4 & 4 & 4 & 4 & 4 & 4 & 4 \\
\hline Percentage of all CWSs with analyses & 0.2 & 0.2 & 0.2 & 0.2 & 0.2 & 0.2 & 0.2 \\
\hline Number of CWSs with detections & 0 & 0 & 0 & 0 & 0 & 0 & 0 \\
\hline Percentage of CWSs with detections & 0 & 0 & 0 & 0 & 0 & 0 & 0 \\
\hline \multicolumn{8}{|l|}{ Methyl tert-butyl ether } \\
\hline Number of analyses & 5,510 & 5,510 & 5,510 & 5,391 & 5,374 & 5,211 & 4,427 \\
\hline Percentage of all analyses that include analyte & 25.5 & 25.5 & 25.5 & 24.9 & 24.8 & 24.1 & 20.5 \\
\hline Number of detections & 343 & 27 & 44 & 82 & 174 & 248 & 337 \\
\hline Percentage of analyses with detections & 6.2 & 0.5 & 0.8 & 1.5 & 3.2 & 4.8 & 7.6 \\
\hline Number of CWSs with analyses & 1,194 & 1,194 & 1,194 & 1,122 & 1,118 & 1,074 & 865 \\
\hline Percentage of all CWSs with analyses & 56.6 & 56.6 & 56.6 & 53.2 & 53.0 & 50.9 & 41 \\
\hline Number of CWSs with detections & 106 & 10 & 17 & 23 & 52 & 84 & 106 \\
\hline Percentage of CWSs with detections & 8.9 & 0.8 & 1.4 & 2.0 & 4.6 & 7.8 & 12.2 \\
\hline \multicolumn{8}{|l|}{ Monochlorobenzene } \\
\hline Number of analyses & 15,944 & 15,944 & 15,944 & 15.944 & 15,943 & 15,943 & 15,704 \\
\hline Percentage of all analyses that include analyte & 73.7 & 73.7 & 73.7 & 73.7 & 73.7 & 73.7 & 72.6 \\
\hline Number of detections & 22 & 0 & 0 & 0 & 1 & 13 & 20 \\
\hline Percentage of analyses with detections & 0.1 & 0 & 0 & 0 & 0.01 & 0.08 & 0.1 \\
\hline Number of CWSs with analyses & 2,096 & 2,096 & 2.096 & 2,096 & 2,096 & 2,096 & 2,096 \\
\hline Percentage of all CWSs with analyses & 99.3 & 99.3 & 99.3 & 99.3 & 99.3 & 99.3 & 99.3 \\
\hline Number of CWSs with detections & 5 & 0 & 0 & 0 & 1 & 2 & 5 \\
\hline Percentage of CWSs with detections & 0.2 & 0 & 0 & 0 & 0.05 & 0.1 & 0.2 \\
\hline \multicolumn{8}{|l|}{ Naphthalene } \\
\hline Number of analyses & 7,224 & 7,224 & 7,224 & 7.223 & 7,223 & 7,220 & 6.692 \\
\hline Percentage of all analyses that include analyte & 33.4 & 33.4 & 33.4 & 33.4 & 33.4 & 33.4 & 30.9 \\
\hline Number of detections & 9 & 0 & 0 & 0 & 2 & 4 & 8 \\
\hline Percentage of analyses with detections & 0.1 & 0 & 0 & 0 & 0.03 & 0.06 & 0.1 \\
\hline Number of CWSs with analyses & 1,379 & 1.379 & 1,379 & 1,378 & 1.378 & 1,378 & 1,351 \\
\hline Percentage of all CWSs with analyses & 65.4 & 65.4 & 65.4 & 65.3 & 65.3 & 65.3 & 64.0 \\
\hline Number of CWSs with detections & 8 & 0 & 0 & 0 & 2 & 4 & 7 \\
\hline Percentage of CWSs with detections & 0.6 & 0 & 0 & 0 & 0.2 & 0.3 & 0.5 \\
\hline
\end{tabular}


Appendix 3. Frequency of reporting and frequency of detection of volatile organic compounds included in analyses of drinking water for randomly selected community water systems in the study area compared by reporting levels, 1993-98-Continued

[Data for any reporting level include all data reported by States for specified analyte without regard to differences in minimum reporting levels or method detection limits, whereas data for specific censoring leveIs have been censored to remove samples with a reporting Ievel higher than the specified censoring level, and all reported detectable concentrations of the specified analyte below the censoring level have been converted to "less than" values; $\mu \mathrm{g} / \mathrm{L}$. micrograms per liter; CWSs, community water systems]

\begin{tabular}{|c|c|c|c|c|c|c|c|}
\hline Volatile organic compound and statistic & \multicolumn{7}{|c|}{ Reporting or censoring level } \\
\hline \multicolumn{8}{|l|}{ Nitrobenzene } \\
\hline Number of analyses & 24 & 24 & 24 & 24 & 24 & 23 & 23 \\
\hline Percentage of all analyses that include analyte & 0.1 & $0 . \mathrm{I}$ & 0.1 & 0.1 & 0.1 & 0.1 & 0.1 \\
\hline Number of detections & 0 & 0 & 0 & 0 & 0 & 0 & 0 \\
\hline Number of CWSs with analyses & 4 & 4 & 4 & 4 & 4 & 3 & 3 \\
\hline Percentage of all CWSs with analyses & 0.2 & 0.2 & 0.2 & 0.2 & 0.2 & 0.1 & 0.1 \\
\hline Number of CWSs with detections & 0 & 0 & 0 & 0 & 0 & 0 & 0 \\
\hline Percentage of CWSs with detections & 0 & 0 & 0 & 0 & 0 & 0 & 0 \\
\hline Number of detections & 0 & 0 & 0 & 0 & 0 & 0 & 0 \\
\hline Percentage of analyses with detections & 0 & 0 & 0 & 0 & 0 & 0 & 0 \\
\hline Number of CWSs with analyses & 4 & 4 & 4 & 4 & 4 & 4 & 4 \\
\hline Percentage of all CWSs with analyses & 0.2 & 0.2 & 0.2 & 0.2 & 0.2 & 0.2 & 0.2 \\
\hline Number of CWSs with detections & 0 & 0 & 0 & 0 & 0 & 0 & 0 \\
\hline Percentage of CWSs with detections & 0 & 0 & 0 & 0 & 0 & 0 & 0 \\
\hline \multicolumn{8}{|l|}{ n-Propylbenzene } \\
\hline Number of analyses & 12,019 & 12,019 & 12,019 & 12,019 & 12,019 & 12,019 & 11,479 \\
\hline Percentage of CWSs with detections & 0.2 & 0 & 0 & 0.06 & 0.1 & 0.1 & 0.2 \\
\hline \multicolumn{8}{|l|}{ Styrene } \\
\hline Number of analyses & 15,584 & 15.584 & 15,584 & 15,584 & 15,584 & 15,584 & 15,350 \\
\hline Percentage of all analyses that include analyte & 72.0 & 72.0 & 72.0 & 72.0 & 72.0 & 72.0 & 71.0 \\
\hline Number of detections & 5 & 0 & 0 & 1 & 1 & 3 & 5 \\
\hline Percentage of analyses with detections & 0.03 & 0 & 0 & 0.01 & 0.01 & 0.02 & 0.03 \\
\hline Number of CWSs with analyses & 2,078 & 2,078 & 2,078 & 2,078 & 2,078 & 2.078 & 2,078 \\
\hline Percentage of all CWSs with analyses & 98.5 & 98.5 & 98.5 & 98.5 & 98.5 & 98.5 & 98.5 \\
\hline Number of CWSs with detections & 5 & 0 & 0 & 1 & 1 & 3 & 5 \\
\hline Percentage of CWSs with detections & 0.2 & 0 & 0 & 0.05 & 0.05 & 0.1 & 0.2 \\
\hline
\end{tabular}


Appendix 3. Frequency of reporting and frequency of detection of volatile organic compounds included in analyses of drinking water for randomly selected community water systems in the study area compared by reporting levels, 1993-98-Cor tinued

[Data for any reporting level include all data reported by States for specified analyte without regard to differences in minimum reporting levels or method detection limits. whereas data for specific censoring levels have been censored to remove samples with a reporting level higher than the specifie $t$ censoring level, and all reported detectable concentrations of the specified analyte below the censoring level have been converted to "less than" values; $\mu \mathrm{g} / \mathrm{L}$, micrograms per liter; CWSs, community water systems]

\begin{tabular}{|c|c|c|c|c|c|c|c|}
\hline \multirow{2}{*}{ Volatile organic compound and statistic } & \multicolumn{7}{|c|}{ Reporting or censoring level } \\
\hline & Any & $20 \mu \mathrm{g} / \mathrm{L}$ & $10 \mu \mathrm{g} / \mathrm{L}$ & $5.0 \mu \mathrm{g} / \mathrm{L}$ & $2.0 \mu \mathrm{g} / \mathrm{L}$ & $1.0 \mu \mathrm{g} / \mathrm{L}$ & $0.5 \mu \mathrm{g} / \mathrm{L}$ \\
\hline \multicolumn{8}{|l|}{ 1,1,1,2-Tetrachloroethane } \\
\hline Number of analyses & 12,727 & 12.727 & 12,727 & 12,727 & 12,727 & 12,727 & 12,150 \\
\hline Percentage of all analyses that include analyte & 58.8 & 58.8 & 58.8 & 58.8 & 58.8 & 58.8 & 56.2 \\
\hline Number of detections & 2 & 0 & 0 & 0 & 0 & 2 & 2 \\
\hline Percentage of analyses with detections & 0.02 & 0 & 0 & 0 & 0 & 0.02 & 0.02 \\
\hline Number of CWSs with analyses & 1,667 & 1.667 & 1,667 & 1,667 & 1,667 & 1,667 & 1,641 \\
\hline Percentage of all CWSs with analyses & 79.0 & 79.0 & 79.0 & 79.0 & 79.0 & 79.0 & 77.8 \\
\hline Number of CWSs with detections & 2 & 0 & 0 & 0 & 0 & 2 & 2 \\
\hline Percentage of CWSs with detections & 0.1 & 0 & 0 & 0 & 0 & 0.1 & 0.1 \\
\hline \multicolumn{8}{|l|}{ 1,1,2,2-Tetrachloroethane } \\
\hline Number of analyses & 12.548 & 12,548 & 12.548 & $12, \overline{548}$ & 12,547 & 12,547 & 12,029 \\
\hline Percentage of all analyses that include analyte & 58.0 & 58.0 & 58.0 & 58.0 & 58.0 & 58.0 & 55.6 \\
\hline Number of detections & 1 & 0 & 0 & 0 & 1 & 1 & I \\
\hline Percentage of analyses with detections & 0.01 & 0 & 0 & 0 & 0.01 & 0.01 & 0.01 \\
\hline Number of CWSs with analyses & 1,581 & 1,581 & 1.581 & 1,581 & 1,581 & 1,581 & 1,555 \\
\hline Percentage of all CWSs with analyses & 74.9 & 74.9 & 74.9 & 74.9 & 74.9 & 74.9 & 73.7 \\
\hline Number of CWSs with detections & 1 & 0 & 0 & 0 & 1 & 1 & 1 \\
\hline Percentage of CWSs with detections & 0.06 & 0 & 0 & 0 & 0.06 & 0.06 & 0.06 \\
\hline \multicolumn{8}{|l|}{ Tetrachloroethylene } \\
\hline Number of analyses & 16,082 & 16,082 & 16,082 & 16,082 & 16,080 & 16,080 & 15,849 \\
\hline Percentage of all analyses that include analyte & 74.3 & 74.3 & 74.3 & 74.3 & 74.3 & 74.3 & 73.3 \\
\hline Number of detections & 1,613 & 243 & 359 & 514 & 923 & 1,265 & 1,551 \\
\hline Percentage of analyses with detections & 10.0 & 1.5 & 2.2 & 3.2 & 5.7 & 7.9 & 9.8 \\
\hline Number of CWSs with analyses & 2,090 & 2,090 & 2,090 & 2,090 & 2,090 & 2,090 & 2,090 \\
\hline Percentage of aII CWSs with analyses & 99.0 & 99.0 & 99.0 & 99.0 & 99.0 & 99.0 & 99.0 \\
\hline Number of CWSs with detections & 93 & 16 & 25 & 32 & 56 & 71 & 90 \\
\hline Percentage of CWSs with detections & 4.4 & 0.8 & 1.2 & 1.5 & 2.7 & 3.4 & 4.3 \\
\hline \multicolumn{8}{|l|}{ Tetrahydrofuran } \\
\hline Number of analyses & 404 & 404 & 404 & 404 & 404 & 404 & 404 \\
\hline Percentage of all analyses that include analyte & 1.9 & 1.9 & 1.9 & 1.9 & 1.9 & 1.9 & 1.9 \\
\hline Number of detections & 2 & 2 & 2 & 2 & 2 & 2 & 2 \\
\hline Percentage of analyses with detections & 0.5 & 0.5 & 0.5 & 0.5 & 0.5 & 0.5 & 0.5 \\
\hline Number of CWSs with analyses & 136 & 136 & 136 & 136 & 136 & 136 & 136 \\
\hline Percentage of all CWSs with analyses & 6.4 & 6.4 & 6.4 & 6.4 & 6.4 & 6.4 & 6.4 \\
\hline Number of CWSs with detections & 2 & 2 & 2 & 2 & 2 & 2 & 2 \\
\hline Percentage of CWSs with detections & 1.5 & 1.5 & 1.5 & 1.5 & 1.5 & 1.5 & 1.5 \\
\hline
\end{tabular}


Appendix 3. Frequency of reporting and frequency of detection of volatile organic compounds included in analyses of drinking water for randomly selected community water systems in the study area compared by reporting levels, 1993-98-Continued

[Data for any reporting level include all data reported by States for specified analyte without regard to differences in minimum reporting levels or method detection limits, whereas data for specific censoring levels have been censored to remove samples with a reporting level higher than the specifi :d censoring level, and all reported detectable concentrations of the specified analyte below the censoring level have been converted to "less than" values; $\mu \mathrm{g} / \mathrm{L}$, micrograms per liter; CWSs, community water systems]

\begin{tabular}{|c|c|c|c|c|c|c|c|}
\hline \multirow{2}{*}{ Volatile organic compound and statistic } & \multicolumn{7}{|c|}{ Reporting or censoring level } \\
\hline & Any & $20 \mu \mathrm{g} / \mathrm{L}$ & $10 \mu \mathrm{g} / \mathrm{L}$ & $5.0 \mu \mathrm{g} / \mathrm{L}$ & $2.0 \mu \mathrm{g} / \mathrm{L}$ & $1.0 \mu \mathrm{g} / \mathrm{L}$ & $0.5 \mu g / L$ \\
\hline \multicolumn{8}{|l|}{ Toluene } \\
\hline Number of analyses & 15,822 & 15,822 & 15,822 & 15,822 & 15,821 & 15,821 & 15,583 \\
\hline Percentage of all analyses that include analyte & 73.1 & 73.1 & 73.1 & 73.1 & 73.1 & 73.1 & 72.0 \\
\hline Number of detections & 134 & 15 & 17 & 21 & 40 & 79 & 131 \\
\hline Percentage of analyses with detections & 0.8 & 0.09 & 0.1 & 0.1 & 0.2 & 0.5 & 0.8 \\
\hline Number of CWSs with analyses & 2,095 & 2,095 & 2,095 & 2,095 & 2,095 & 2,095 & 2,095 \\
\hline Percentage of all CWSs with analyses & 99.3 & 99.3 & 99.3 & 99.3 & 99.3 & 99.3 & 99.3 \\
\hline Number of CWSs with detections & 88 & 9 & 10 & 14 & 28 & 53 & 86 \\
\hline Percentage of CWSs with detections & 4.2 & 0.4 & 0.5 & 0.7 & 1.3 & 2.5 & 4.1 \\
\hline \multicolumn{8}{|l|}{ 1,1,2-Trichloro-1,2,2-trifluoroethane } \\
\hline Number of analyses & 172 & 172 & 172 & 172 & 172 & 172 & 172 \\
\hline Percentage of all analyses that include analyte & 0.8 & 0.8 & 0.8 & 0.8 & 0.8 & 0.8 & 0.8 \\
\hline Number of detections & 0 & 0 & 0 & 0 & 0 & 0 & 0 \\
\hline Percentage of analyses with detections & 0 & 0 & 0 & 0 & 0 & 0 & 0 \\
\hline Number of CWSs with analyses & 80 & 80 & 80 & 80 & 80 & 80 & 80 \\
\hline Percentage of all CWSs with analyses & 3.8 & 3.8 & 3.8 & 3.8 & 3.8 & 3.8 & 3.8 \\
\hline Number of CWSs with detections & 0 & 0 & 0 & 0 & 0 & 0 & 0 \\
\hline Percentage of CWSs with detections & 0 & 0 & 0 & 0 & 0 & 0 & 0 \\
\hline \multicolumn{8}{|l|}{ 1,2,3-Trichlorobenzene } \\
\hline Number of analyses & 11,918 & 11,918 & 11,918 & 11,918 & 11,918 & 11,915 & 11,377 \\
\hline Percentage of all analyses that include analyte & 55.1 & 55.1 & 55.1 & 55.1 & 55.1 & 55.1 & 52.6 \\
\hline Number of detections & 2 & 0 & 0 & 0 & 0 & 0 & 2 \\
\hline Percentage of analyses with detections & 0.02 & 0 & 0 & 0 & 0 & 0 & 0.02 \\
\hline Number of CWSs with analyses & 1,550 & 1,550 & 1.550 & 1,550 & 1,550 & 1,550 & 1,523 \\
\hline Percentage of all CWSs with analyses & 73.5 & 73.5 & 73.5 & 73.5 & 73.5 & 73.5 & 72.2 \\
\hline Number of CWSs with detections & 1 & 0 & 0 & 0 & 0 & 0 & 1 \\
\hline Percentage of CWSs with detections & 0.06 & 0 & 0 & 0 & 0 & 0 & 0.07 \\
\hline \multicolumn{8}{|l|}{ 1,2,4-Trichlorobenzene } \\
\hline Number of analyses & 15,461 & 15,461 & 15,461 & 15,460 & 15,460 & 15,460 & 15,223 \\
\hline Percentage of all analyses that include analyte & 71.5 & 71.5 & 71.5 & 71.5 & 71.5 & 71.5 & 70.4 \\
\hline Number of detections & 9 & 0 & 0 & 0 & 0 & 4 & 8 \\
\hline Percentage of analyses with detections & 0.06 & 0 & 0 & 0 & 0 & 0.03 & 0.05 \\
\hline Number of CWSs with analyses & 2,092 & 2,092 & 2,092 & 2,092 & 2,092 & 2,092 & 2,092 \\
\hline Percentage of all CWSs with analyses & 99.2 & 99.2 & 99.2 & 99.2 & 99.2 & 99.2 & 99.2 \\
\hline Number of CWSs with detections & 7 & 0 & 0 & 0 & 0 & 4 & 6 \\
\hline Percentage of CWSs with detections & 0.3 & 0 & 0 & 0 & 0 & 0.2 & 0.3 \\
\hline
\end{tabular}


Appendix 3. Frequency of reporting and frequency of detection of volatile organic compounds included in analyses of drinking water for randomly selected community water systems in the study area compared by reporting levels, 1993-98-Cor tinued

[Data for any reporting level include all data reported by States for specified analyte without regard to differences in minimum reporting levels or method detection limits, whereas data for specific censoring levels have been censored to remove samples with a reporting level higher than the specifie $t_{\text {censoring }}$ level, and all reported detectable concentrations of the specified analyte below the censoring level have been converted to "less than" values; $\mu \mathrm{g} / \mathrm{L}$, micrograms per liter; CWSs, community water systems]

\begin{tabular}{|c|c|c|c|c|c|c|c|}
\hline \multirow{2}{*}{ Volatile organic compound and statistic } & \multicolumn{7}{|c|}{ Reporting or censoring level } \\
\hline & Any & $20 \mu \mathrm{g} / \mathrm{L}$ & $10 \mu \mathrm{g} / \mathrm{L}$ & $5.0 \mu \mathrm{g} / \mathrm{L}$ & $2.0 \mu \mathrm{g} / \mathrm{L}$ & $1.0 \mu \mathrm{g} / \mathrm{L}$ & $0.5 \mu \mathrm{g} / \mathrm{L}$ \\
\hline \multicolumn{8}{|l|}{ 1,1,1-Trichloroethane } \\
\hline Percentage of all analyses that include analyte & 74.5 & 74.5 & 74.5 & 74.5 & 74.5 & 74.5 & 74.4 \\
\hline Number of detections & 1,097 & 87 & 145 & 218 & 433 & 714 & 1,060 \\
\hline Number of CWSs with analyses & 2,086 & 2,086 & 2,086 & 2,086 & 2,086 & 2,086 & 2,086 \\
\hline Percentage of all CWSs with analyses & 98.9 & 98.9 & 98.9 & 98.9 & 98.9 & 98.9 & 98.9 \\
\hline Number of CWSs with detections & 106 & 8 & 15 & 27 & 53 & 77 & 101 \\
\hline Percentage of CWSs with detections & 5.1 & 0.4 & 0.7 & 1.3 & 2.5 & 3.7 & 4.8 \\
\hline Number of detections & 9 & 0 & 0 & 0 & 1 & 2 & 9 \\
\hline Percentage of analyses with detections & 0.06 & 0 & 0 & 0 & 0.01 & 0.01 & 0.06 \\
\hline Number of CWSs with analyses & 2,088 & 2,088 & 2,088 & 2,088 & 2,088 & 2,088 & 2,088 \\
\hline Percentage of all CWSs with analyses & 99.0 & 99.0 & 99.0 & 99.0 & 99.0 & 99.0 & 99.0 \\
\hline Number of CWSs with detections & 6 & 0 & 0 & 0 & 1 & 2 & 6 \\
\hline Percentage of CWSs with detections & 0.3 & 0 & 0 & 0 & 0.05 & 0.1 & 0.3 \\
\hline \multicolumn{8}{|l|}{ Trichloroethylene } \\
\hline Number of analyses & 16,135 & 16,135 & 16,135 & 16,135 & 16,134 & 16,134 & 16,120 \\
\hline Percentage of CWSs with detections & 4.5 & 0.5 & 0.8 & 1.2 & 2.5 & 3.7 & 4.4 \\
\hline \multicolumn{8}{|l|}{ 1,2,3-Trichloropropane } \\
\hline Number of analyses & 12,711 & 12,711 & 12,711 & 12,711 & 12.711 & 12,711 & 12,152 \\
\hline Percentage of all analyses that include analyte & 58.8 & 58.8 & 58.8 & 58.8 & 58.8 & 58.8 & 56.2 \\
\hline Number of detections & 47 & 0 & 0 & 0 & 15 & 29 & 47 \\
\hline Percentage of analyses with detections & 0.4 & 0 & 0 & 0 & 0.1 & 0.2 & 0.4 \\
\hline Number of CWSs with analyses & 1,665 & 1,665 & 1,665 & 1,665 & 1,665 & 1,665 & 1,639 \\
\hline Percentage of all CWSs with analyses & 78.9 & 78.9 & 78.9 & 78.9 & 78.9 & 78.9 & 77.7 \\
\hline Number of CWSs with detections & 4 & 0 & 0 & 0 & 2 & 3 & 4 \\
\hline Percentage of CWSs with detections & 0.2 & 0 & 0 & 0 & 0.1 & 0.2 & 0.2 \\
\hline
\end{tabular}


Appendix 3. Frequency of reporting and frequency of detection of volatile organic compounds included in analyses of drinking water for randomly selected community water systems in the study area compared by reporting levels, 1993-98-Continued

[Data for any reporting level include all data reported by States for specified analyte without regard to differences in minimum reporting levels or method detection limits, whereas data for specific censoring levels have been censored to remove samples with a reporting level higher than the specified censoring level, and all reported detectable concentrations of the specified analyte below the censoring level have been converted to "less than" values; $\mu \mathrm{g} / \mathrm{L}$, micrograms per liter; CWSs, community water systems]

\begin{tabular}{|c|c|c|c|c|c|c|c|}
\hline \multirow{2}{*}{ Volatile organic compound and statistic } & \multicolumn{7}{|c|}{ Reporting or censoring level } \\
\hline & Any & $20 \mu \mathbf{g} / \mathbf{L}$ & $10 \mu \mathrm{g} / \mathrm{L}$ & $5.0 \mu \mathrm{g} / \mathrm{L}$ & $2.0 \mu \mathrm{g} / \mathrm{L}$ & $1.0 \mu \mathrm{g} / \mathrm{L}$ & $0.5 \mu \mathrm{g} / \mathrm{L}$ \\
\hline \multicolumn{8}{|l|}{ Trihalomethanes, total } \\
\hline Number of analyses & 3,549 & 3,549 & 3,549 & 3,549 & 3,544 & 3,543 & 3,543 \\
\hline Percentage of all analyses that include analyte & 16.4 & 16.4 & 16.4 & 16.4 & 16.4 & 16.4 & 16.4 \\
\hline Number of detections & 2,448 & 1,712 & 2,045 & 2,191 & 2,325 & 2,378 & 2,447 \\
\hline Percentage of analyses with detections & 69.0 & 48.2 & 57.6 & 61.7 & 65.6 & 67.1 & 69.1 \\
\hline Number of CWSs with analyses & 304 & 304 & 304 & 304 & 302 & 302 & 302 \\
\hline Percentage of all CWSs with analyses & 14.4 & 14.4 & 14.4 & 14.4 & 14.3 & 14.3 & 14.3 \\
\hline Number of CWSs with detections & 125 & 87 & 99 & 108 & 113 & 120 & 125 \\
\hline Percentage of CWSs with detections & 41.1 & 28.6 & 32.6 & 35.5 & 37.4 & 39.7 & 41.4 \\
\hline \multicolumn{8}{|l|}{ Trihalomethanes, calculated } \\
\hline Number of analyses & 15,756 & 15,754 & 15,754 & 15,754 & 15.747 & 15.732 & 15.182 \\
\hline Percentage of all analyses that include analyte & 72.8 & 72.8 & 72.8 & 72.8 & 72.8 & 72.7 & 70.2 \\
\hline Number of detections & 5,850 & 3,017 & 3,766 & 4,327 & 4,865 & 5,315 & 5.802 \\
\hline Percentage of analyses with detections & 37.1 & 19.2 & 23.9 & 26.9 & 30.9 & 33.8 & 38.2 \\
\hline Number of CWSs with analyses & 1,543 & 1,543 & 1,543 & 1,543 & 1,540 & 1,537 & 1,520 \\
\hline Percentage of all CWSs with analyses & 73.1 & 73.1 & 73.1 & 73.1 & 73.0 & 72.8 & 72.0 \\
\hline Number of CWSs with detections & 702 & 279 & 358 & 440 & 570 & 644 & 699 \\
\hline Percentage of CWSs with detections & 45.5 & 18.1 & 23.2 & 28.5 & 37.0 & 41.9 & 46.0 \\
\hline \multicolumn{8}{|l|}{ 1,2,3-Trimethylbenzene } \\
\hline Number of analyses & 389 & 389 & 389 & 389 & 389 & 389 & 376 \\
\hline Percentage of all analyses that include analyte & 1.8 & 1.8 & 1.8 & 1.8 & 1.8 & 1.8 & 1.7 \\
\hline Number of detections & 0 & 0 & 0 & 0 & 0 & 0 & 0 \\
\hline Percentage of analyses with detections & 0 & 0 & 0 & 0 & 0 & 0 & 0 \\
\hline Number of CWSs with analyses & 101 & 101 & 101 & 101 & 101 & 101 & 101 \\
\hline Percentage of all CWSs with analyses & 4.8 & 4.8 & 4.8 & 4.8 & 4.8 & 4.8 & 4.8 \\
\hline Number of CWSs with detections & 0 & 0 & 0 & 0 & 0 & 0 & 0 \\
\hline Percentage of CWSs with detections & 0 & 0 & 0 & 0 & 0 & 0 & 0 \\
\hline \multicolumn{8}{|l|}{ 1,2,4-Trimethylbenzene } \\
\hline Number of analyses & 12,011 & 12,011 & 12,011 & 12,011 & 12,011 & 12,011 & 11,472 \\
\hline Percentage of all analyses that include analyte & 55.5 & 55.5 & 55.5 & 55.5 & 55.5 & 55.5 & 53.0 \\
\hline Number of detections & 26 & 1 & 2 & 2 & 12 & 21 & 25 \\
\hline Percentage of analyses with detections & 0.2 & 0.01 & 0.02 & 0.02 & 0.1 & 0.2 & 0.2 \\
\hline Number of CWSs with analyses & 1,567 & 1.567 & 1,567 & 1,567 & 1,567 & 1,567 & 1,541 \\
\hline Percentage of all CWSs with analyses & 74.3 & 74.3 & 74.3 & 74.3 & 74.3 & 74.3 & 73.0 \\
\hline Number of CWSs with detections & 9 & 1 & 2 & 2 & 3 & 5 & 8 \\
\hline Percentage of CWSs with detections & 0.6 & 0.06 & 0.1 & 0.1 & 0.2 & 0.3 & 0.5 \\
\hline
\end{tabular}


Appendix 3. Frequency of reporting and frequency of detection of volatile organic compounds included in analyses of drinking water for randomly selected community water systems in the study area compared by reporting levels, 1993-98-Con+inued

[Data for any reporting level include all data reported by States for specified analyte without regard to differences in minimum reporting levels or method detection limits, whereas data for specific censoring levels have been censored to remove samples with a reporting level higher than the specified censoring level, and all reported detectable concentrations of the specified analyte below the censoring level have been converted to "less than" values; $\mu \mathrm{g} / \mathrm{L}$, micrograms per liter; CWSs, community water systems]

\begin{tabular}{|c|c|c|c|c|c|c|c|}
\hline \multirow{2}{*}{ Volatile organic compound and statistic } & \multicolumn{7}{|c|}{ Reporting or censoring level } \\
\hline & Any & $20 \mu \mathrm{g} / \mathrm{L}$ & $10 \mu \mathrm{g} / \mathrm{L}$ & $5.0 \mu \mathrm{g} / \mathrm{L}$ & $2.0 \mu \mathrm{g} / \mathrm{L}$ & $1.0 \mu \mathrm{g} / \mathrm{L}$ & $0.5 \mu \mathrm{g} / \mathrm{L}$ \\
\hline \multicolumn{8}{|l|}{ 1,3,5-Trimethylbenzene } \\
\hline Number of analyses & 12,017 & 12,017 & 12,017 & 12,017 & 12,017 & 12,017 & 11,462 \\
\hline Percentage of all analyses that include analyte & 55.5 & 55.5 & 55.5 & 55.5 & 55.5 & 55.5 & 53.0 \\
\hline Number of detections & 23 & 0 & 1 & 2 & 5 & 12 & 23 \\
\hline Percentage of analyses with detections & 0.2 & 0 & 0.01 & 0.02 & 0.04 & 0.1 & 0.2 \\
\hline Number of CWSs with analyses & 1,568 & 1.568 & 1,568 & 1.568 & 1,568 & 1,568 & 1,542 \\
\hline Percentage of all CWSs with analyses & 74.3 & 74.3 & 74.3 & 74.3 & 74.3 & 74.3 & 73.1 \\
\hline Number of CWSs with detections & 7 & 0 & 1 & 2 & 3 & 5 & 7 \\
\hline Percentage of CWSs with detections & 0.4 & 0 & 0.06 & 0.1 & 0.2 & 0.3 & 0.4 \\
\hline \multicolumn{8}{|l|}{ Vinyl chloride } \\
\hline Number of analyses & 15,054 & 15,054 & 15,054 & 15,054 & 15,054 & 15,053 & 15,034 \\
\hline Percentage of all analyses that include analyte & 69.6 & 69.6 & 69.6 & 69.6 & 69.6 & 69.6 & 69.5 \\
\hline Number of detections & 62 & 1 & 1 & 3 & 12 & 39 & 62 \\
\hline Percentage of analyses with detections & 0.4 & 0.01 & 0.01 & 0.02 & 0.08 & 0.3 & 0.4 \\
\hline Number of CWSs with analyses & 2,062 & 2,062 & 2,062 & 2,062 & 2,062 & 2,062 & 2,062 \\
\hline Percentage of all CWSs with analyses & 97.7 & 97.7 & 97.7 & 97.7 & 97.7 & 97.7 & 97.7 \\
\hline Number of CWSs with detections & 9 & 1 & 1 & 2 & 4 & 8 & 9 \\
\hline Percentage of CWSs with detections & 0.4 & 0.05 & 0.05 & 0.1 & 0.2 & 0.4 & 0.4 \\
\hline \multicolumn{8}{|l|}{ m-Xylene } \\
\hline Number of analyses & 7,897 & 7,897 & 7,897 & 7.897 & 7.897 & 7,897 & 7.892 \\
\hline Percentage of all analyses that include analyte & 36.5 & 36.5 & 36.5 & 36.5 & 36.5 & 36.5 & 36.5 \\
\hline Number of detections & 33 & 0 & 0 & 2 & 8 & 17 & 30 \\
\hline Percentage of analyses with detections & 0.4 & 0 & 0 & 0.03 & 0.1 & 0.2 & 0.4 \\
\hline Number of CWSs with analyses & 600 & 600 & 600 & 600 & 600 & 600 & 600 \\
\hline Percentage of all CWSs with analyses & 28.4 & 28.4 & 28.4 & 28.4 & 28.4 & 28.4 & 28.4 \\
\hline Number of CWSs with detections & 17 & 0 & 0 & 2 & 7 & 13 & 15 \\
\hline Percentage of CWSs with detections & 2.8 & 0 & 0 & 0.3 & 1.2 & 2.2 & 2.5 \\
\hline \multicolumn{8}{|l|}{$o$-Xylene } \\
\hline Number of analyses & 10,331 & 10,331 & 10,331 & 10,331 & 10,331 & 10,330 & 10,315 \\
\hline Percentage of all analyses that include analyte & 47.8 & 47.8 & 47.8 & 47.8 & 47.8 & 47.8 & 47.7 \\
\hline Number of detections & 51 & 2 & 2 & 3 & 13 & 27 & 49 \\
\hline Percentage of analyses with detections & 0.5 & 0.02 & 0.02 & 0.03 & 0.1 & 0.3 & 0.5 \\
\hline Number of CWSs with analyses & 1,423 & 1.423 & 1.423 & 1.423 & 1,423 & 1,423 & 1,423 \\
\hline Percentage of all CWSs with analyses & 67.4 & 67.4 & 67.4 & 67.4 & 67.4 & 67.4 & 67.4 \\
\hline Number of CWSs with detections & 32 & 2 & 2 & 3 & 11 & 19 & 31 \\
\hline Percentage of CWSs with detections & 2.2 & 0.1 & 0.1 & 0.2 & 0.8 & 1.3 & 2.2 \\
\hline
\end{tabular}


Appendix 3. Frequency of reporting and frequency of detection of volatile organic compounds included in analyses of drinking water for randomly selected community water systems in the study area compared by reporting levels, 1993-98-Continued

[Data for any reporting level include all data reported by States for specified analyte without regard to differences in minimum reporting levels or method detection limits, whereas data for specific censoring levels have been censored to remove samples with a reporting level higher than the specifiad censoring level, and all reported detectable concentrations of the specified analyte below the censoring level have been converted to "less than" values; $\mu \mathrm{g} / \mathrm{L}$, micrograms per liter; CWSs, community water systems]

\begin{tabular}{|c|c|c|c|c|c|c|c|}
\hline \multirow{2}{*}{ Volatile organic compound and statistic } & \multicolumn{7}{|c|}{ Reporting or censoring level } \\
\hline & Any & $20 \mu \mathrm{g} / \mathrm{L}$ & $10 \mu \mathrm{g} / \mathrm{L}$ & $5.0 \mu \mathrm{g} / \mathrm{L}$ & $2.0 \mu \mathrm{g} / \mathrm{L}$ & $1.0 \mu \mathrm{g} / \mathrm{L}$ & $0.5 \mu \mathrm{g} / \mathrm{L}$ \\
\hline \multicolumn{8}{|l|}{$p$-Xylene } \\
\hline Number of analyses & 8,311 & 8,311 & 8,311 & 8,311 & 8,311 & 8,311 & 8,306 \\
\hline Percentage of all analyses that include analyte & 38.4 & 38.4 & 38.4 & 38.4 & 38.4 & 38.4 & 38.4 \\
\hline Number of detections & 15 & 0 & 0 & 0 & 4 & 6 & 12 \\
\hline Percentage of analyses with detections & 0.2 & 0 & 0 & 0 & 0.05 & 0.07 & 0.1 \\
\hline Number of CWSs with analyses & 683 & 683 & 683 & 683 & 683 & 683 & 683 \\
\hline Percentage of all CWSs with analyses & 32.4 & 32.4 & 32.4 & 32.4 & 32.4 & 32.4 & 32.4 \\
\hline Number of CWSs with detections & 11 & 0 & 0 & 0 & 3 & 4 & 9 \\
\hline Percentage of CWSs with detections & 1.6 & 0 & 0 & 0 & 0.4 & 0.6 & 1.3 \\
\hline \multicolumn{8}{|l|}{$m$ - \& $p$-Xylenes } \\
\hline Number of analyses & 2.426 & 2,426 & 2,426 & 2,426 & 2,426 & 2,426 & 2,406 \\
\hline Percentage of all analyses that include analyte & 11.2 & 11.2 & 11.2 & 11.2 & 11.2 & 11.2 & 11.1 \\
\hline Number of detections & 26 & 3 & 7 & 7 & 12 & 19 & 26 \\
\hline Percentage of analyses with detections & 1.1 & 0.1 & 0.3 & 0.3 & 0.5 & 0.8 & 1.1 \\
\hline Number of CWSs with analyses & 876 & 876 & 876 & 876 & 876 & 876 & 876 \\
\hline Percentage of all CWSs with analyses & 41.5 & 41.5 & 41.5 & 41.5 & 41.5 & 41.5 & 41.5 \\
\hline Number of CWSs with detections & 16 & 3 & 5 & 5 & 9 & 13 & 16 \\
\hline Percentage of CWSs with detections & 1.8 & 0.3 & 0.6 & 0.6 & 1.0 & 1.5 & 1.8 \\
\hline \multicolumn{8}{|l|}{$m$ - \& p-Xylenes, calculated } \\
\hline Number of analyses & 10,356 & 10,356 & 10,356 & 10,356 & 10,356 & 10,356 & 10,331 \\
\hline Percentage of all analyses that include analyte & 47.9 & 47.9 & 47.9 & 47.9 & 47.9 & 47.9 & 47.8 \\
\hline Number of detections & 49 & 3 & 7 & 8 & 21 & 36 & 49 \\
\hline Percentage of analyses with detections & 0.5 & 0.03 & 0.07 & 0.08 & 0.2 & 0.4 & 0.5 \\
\hline Number of CWSs with analyses & 1,443 & 1,443 & 1,443 & 1,443 & 1,443 & 1,443 & 1,443 \\
\hline Percentage of all CWSs with analyses & 68.4 & 68.4 & 68.4 & 68.4 & 68.4 & 68.4 & 68.4 \\
\hline Number of CWSs with detections & 29 & 3 & 5 & 6 & 16 & 23 & 29 \\
\hline Percentage of CWSs with detections & 2.0 & 0.2 & 0.4 & 0.4 & 1.1 & 1.6 & 2.0 \\
\hline \multicolumn{8}{|l|}{ Xylenes, total } \\
\hline Number of analyses & 9,643 & 9,643 & 9,643 & 9,643 & 9,642 & 9,531 & 9,297 \\
\hline Percentage of all analyses that include analyte & 44.6 & 44.6 & 44.6 & 44.6 & 44.6 & 44.0 & 43.0 \\
\hline Number of detections & 109 & 12 & 26 & 43 & 64 & 87 & 108 \\
\hline Percentage of analyses with detections & 1.1 & 0.1 & 0.3 & 0.4 & 0.7 & 0.9 & 1.2 \\
\hline Number of CWSs with analyses & 1,339 & 1,339 & 1,339 & 1,339 & 1,339 & 1,339 & 1,339 \\
\hline Percentage of all CWSs with analyses & 63.5 & 63.5 & 63.5 & 63.5 & 63.5 & 63.5 & 63.5 \\
\hline Number of CWSs with detections & 57 & 6 & 13 & 24 & 35 & 43 & 56 \\
\hline Percentage of CWSs with detections & 4.3 & 0.4 & 1.0 & 1.8 & 2.6 & 3.2 & 4.2 \\
\hline
\end{tabular}


Appendix 3. Frequency of reporting and frequency of detection of volatile organic compounds included in analyses of drinking water for randomly selected community water systems in the study area compared by reporting levels, 1993-98-Continued

[Data for any reporting level include all data reported by States for specified analyte without regard to differences in minimum reporting levels or method detection limits. whereas data for specific censoring levels have been censored to remove samples with a reporting level higher than the specified censoring level. and all reported detectable concentrations of the specified analyte below the censoring level have been converted to "less than" values; $\mu \mathrm{g} / \mathrm{L}$, micrograms per liter: CWSs, community water systems]

\begin{tabular}{|c|c|c|c|c|c|c|c|}
\hline \multirow{2}{*}{ Volatile organic compound and statistic } & \multicolumn{7}{|c|}{ Reporting or censoring level } \\
\hline & Any & $20 \mu \mathrm{g} / \mathrm{L}$ & $10 \mu \mathrm{g} / \mathrm{L}$ & $5.0 \mu \mathrm{g} / \mathrm{L}$ & $2.0 \mu \mathrm{g} / \mathrm{L}$ & $1.0 \mu \mathrm{g} / \mathrm{L}$ & $0.5 \mu \mathrm{g} / \mathrm{L}$ \\
\hline \multicolumn{8}{|l|}{ Xylenes, calculated } \\
\hline Number of analyses & 15.939 & 15,939 & 15,939 & 15,939 & 15,939 & 15,937 & 15,692 \\
\hline Percentage of all analyses that include analyte & 73.7 & 73.7 & 73.7 & 73.7 & 73.7 & 73.7 & 72.5 \\
\hline Number of detections & 162 & 16 & 33 & 53 & 90 & 127 & 165 \\
\hline Percentage of analyses with detections & 1.0 & 0.1 & 0.2 & 0.3 & 0.6 & 0.8 & 1.0 \\
\hline Number of CWSs with analyses & 2,096 & 2,096 & 2,096 & 2,096 & 2,096 & 2,096 & 2,096 \\
\hline Percentage of all CWSs with analyses & 99.3 & 99.3 & 99.3 & 99.3 & 99.3 & 99.3 & 99.3 \\
\hline Number of CWSs with detections & 87 & 10 & 18 & 31 & 53 & 67 & 86 \\
\hline Percentage of CWSs with detections & 4.2 & 0.5 & 0.9 & 1.5 & 2.5 & 3.2 & 4.1 \\
\hline
\end{tabular}


Appendix 4. Co-occurrence of volatile organic compounds in drinking water for randomly selected community wat? systems in the study area, 1993-98

[Co-occurrence is calculated as the percentage of samples with detections of compound specified by column that also had detections of compound specified by row, for example, 2.2 percent of the drinking-water samples with benzene detections also had bronochlormethane detections when both compounds were analyzed for in the same sample; values shown in bold when co-occurrence equals or exceeds 20 percent of 10 or more detections of compound specified by column; NA, not applicable; ND, no detections of compound specified by column]

\begin{tabular}{|c|c|c|c|c|c|c|c|c|}
\hline \multirow[b]{2}{*}{ voc } & \multicolumn{8}{|c|}{ Co-occurrence, in percent } \\
\hline & Acetone & Benzene & $\begin{array}{l}\text { Bromo- } \\
\text { chloro- } \\
\text { methane }\end{array}$ & $\begin{array}{l}\text { Bromo- } \\
\text { dichloro- } \\
\text { methane }\end{array}$ & $\begin{array}{l}\text { Bromo- } \\
\text { form }\end{array}$ & $\begin{array}{l}\text { Bromo- } \\
\text { methane }\end{array}$ & $\begin{array}{l}n \text {-Butyl- } \\
\text { benzene }\end{array}$ & $\begin{array}{l}\text { ser-Butyl- } \\
\text { b } \because n z e n e\end{array}$ \\
\hline Acetone & NA & 0 & ND & 3.8 & 0 & 0 & ND & ND \\
\hline Benzene & 0 & NA & 0 & 0.3 & 0 & 0 & 0 & 0 \\
\hline Bromochloromethane & 0 & 2.2 & NA & 0.2 & 0.6 & 0 & 0 & 0 \\
\hline Bromodichloromethane & 41.7 & 6.5 & 22.2 & NA & 68.5 & 16.7 & 9.1 & 100 \\
\hline Bromoform & 0 & 0 & 33.3 & 18.3 & NA & 33.3 & 4.5 & 0 \\
\hline Bromomethane & 0 & 0 & 0 & 0.1 & 0.4 & NA & 0 & 0 \\
\hline n-Butylbenzene & 0 & 0 & 0 & 0.2 & 0.2 & 0 & NA & 0 \\
\hline sec-Butylbenzene & 0 & 0 & 0 & 0.1 & 0 & 0 & 0 & NA \\
\hline Carbon disulfide & 0 & 0 & ND & 0 & 0 & ND & ND & ND \\
\hline Carbon tetrachloride & 0 & 11.5 & 0 & 0.5 & 0.2 & 0 & 0 & 0 \\
\hline Chlorodibromomethane & 16.7 & 6.5 & 22.2 & 61.0 & 83.2 & 33.3 & 9.1 & 0 \\
\hline Chloroethane & 0 & 0 & 0 & 0.2 & 0 & 0 & 0 & 0 \\
\hline Chloroform & 83.3 & 21.7 & 22.2 & 94.6 & 58.4 & 16.7 & 9.1 & 0 \\
\hline Chloromethane & 0 & 0 & 0 & 1.0 & 1.0 & 20 & 0 & 0 \\
\hline$o$-Chlorotoluene & 0 & 0 & 0 & 0.3 & 0 & 0 & 4.5 & 0 \\
\hline$p$-Chlorotoluene & 0 & 0 & 0 & 0.2 & 0.4 & 0 & 4.5 & 0 \\
\hline Dibromochloropropane & 0 & 0 & 0 & 0.5 & 0.3 & 0 & 20 & 0 \\
\hline Dibromomethane & 0 & 0 & 10 & 0.2 & 1.4 & 0 & 0 & 0 \\
\hline$o$-Dichlorobenzene & 0 & 0 & 0 & 0.5 & 0.6 & 0 & 9.1 & 0 \\
\hline$p$-Dichlorobenzene & 0 & 0 & 0 & 0.7 & 1.0 & 0 & 4.5 & 0 \\
\hline Dichlorodifluoromethane & 0 & 8.9 & 0 & 0.2 & 0.2 & 0 & 9.1 & 0 \\
\hline 1,1-Dichloroethane & 0 & 6.4 & 0 & 0.6 & 0.9 & 0 & 0 & 0 \\
\hline 1,2-Dichloroethane & 0 & 5.8 & 0 & 2.2 & 1.7 & 0 & 0 & 0 \\
\hline 1.1-Dichloroethene & 0 & 8.7 & 0 & 0.5 & 0.6 & 0 & 0 & 0 \\
\hline cis-1.2-Dichloroethene & 0 & 13.5 & 10 & 3.3 & 5.1 & 10 & 0 & 0 \\
\hline trans-1,2-Dichloroethene & 0 & 0 & 0 & 0.1 & 0.2 & 0 & 0 & 0 \\
\hline Dichloromethane & 12.5 & 1.9 & 0 & 1.7 & 2.3 & 0 & 0 & 0 \\
\hline 1,2-Dichloropropane & 0 & 1.9 & 0 & 0.6 & 0.6 & 0 & 0 & 0 \\
\hline 1,3-Dichloropropane & 0 & 0 & 0 & 0.4 & 0.2 & 0 & 0 & 0 \\
\hline 2,2-Dichloropropane & 0 & 0 & 0 & 0 & 0 & 0 & 0 & 0 \\
\hline cis-1,3-Dichloropropene & 0 & 0 & 0 & 0 & 0 & 0 & 0 & 0 \\
\hline Ethylbenzene & 0 & 5.8 & 0 & 2.8 & 1.6 & 0 & 4.5 & 0 \\
\hline Ethylene dibromide & 0 & 0 & 0 & 0.1 & 0.3 & 0 & 0 & 0 \\
\hline Fluorotrichloromethane & 0 & 8.9 & 0 & 0.2 & 0.2 & 0 & 0 & 0 \\
\hline Hexachlorobutadiene & 0 & 0 & 0 & 0 & 0 & 0 & 0 & 0 \\
\hline Isopropylbenzene & 0 & 2.2 & 0 & 0 & 0 & 0 & 0 & 0 \\
\hline
\end{tabular}


Appendix 4. Co-occurrence of volatile organic compounds in drinking water for randomly selected community water systems in the study area, 1993-98-Continued

[Co-occurrence is calculated as the percentage of samples with detections of compound specified by column that also had detections of compound specified by row, for example, 2.2 percent of the drinking-water samples with benzene detections aIso had bromochlormethane detections when both compounds were analyzed for in the same sample; values shown in bold when co-occurrence equals or exceeds 20 percent of $I 0$ or more detections of compound specified by column; NA, not applicable; ND, no detections of compound specified by column]

\begin{tabular}{|c|c|c|c|c|c|c|c|c|}
\hline \multirow[b]{2}{*}{ voc } & \multicolumn{8}{|c|}{ Co-occurrence, in percent } \\
\hline & Acetone & Benzene & $\begin{array}{l}\text { Bromo- } \\
\text { chloro- } \\
\text { methane }\end{array}$ & $\begin{array}{l}\text { Bromo- } \\
\text { dichloro- } \\
\text { methane }\end{array}$ & $\begin{array}{l}\text { Bromo- } \\
\text { form }\end{array}$ & $\begin{array}{l}\text { Bromo- } \\
\text { methane }\end{array}$ & $\begin{array}{l}n \text {-Butyl- } \\
\text { benzene }\end{array}$ & $\begin{array}{l}\text { ser-Butyl- } \\
\text { benzene }\end{array}$ \\
\hline$p$-Isopropyltoluene & 0 & 0 & 0 & 0 & 0 & 0 & 13.6 & 0 \\
\hline Methyl ethyl ketone & 0 & 0 & 0 & 2.3 & 1.3 & 0 & ND & ND \\
\hline Methyl isobutyl ketone & 0 & 0 & ND & 1.4 & 1.9 & 0 & ND & ND \\
\hline Methyl tert-butyl ether & 0 & 25.8 & 0 & 5.7 & 8.2 & 0 & 0 & ND \\
\hline Monochlorobenzene & 0 & 7.7 & 0 & 0 & 0 & 0 & 0 & 0 \\
\hline Naphthalene & 0 & 2.5 & 0 & 0.1 & 0 & 0 & 20 & 0 \\
\hline$n$-Propylbenzene & 0 & 0 & 0 & 0.1 & 0 & 0 & 9.1 & 0 \\
\hline Styrene & 0 & 0 & 0 & 0 & 0 & 0 & 0 & 0 \\
\hline 1,1,1,2-Tetrachloroethane & 0 & 0 & 0 & 0 & 0 & 0 & 0 & 0 \\
\hline 1,1,2,2-Tetrachloroethane & 0 & 0 & 0 & 0 & 0 & 0 & 0 & 0 \\
\hline Tetrachloroethylene & 0 & 23.1 & 20 & 2.8 & 10.1 & 0 & 0 & 0 \\
\hline Tetrahydrofuran & 0 & 0 & ND & 0 & 0 & ND & ND & ND \\
\hline Toluene & 0 & 17.3 & 0 & 2.1 & 1.2 & 0 & 4.5 & 0 \\
\hline 1,2,3-Trichlorobenzene & 0 & 0 & 0 & 0 & 0 & 0 & 0 & 0 \\
\hline 1,2,4-Trichlorobenzene & 0 & 0 & 0 & 0.1 & 0.2 & 0 & 4.5 & 0 \\
\hline 1,1,1-Trichloroethane & 0 & 13.5 & 0 & 2.2 & 3.2 & 0 & 0 & 100 \\
\hline 1,1,2-Trichloroethane & 0 & 0 & 0 & 0.3 & 0 & 0 & 0 & 0 \\
\hline Trichloroethylene & 0 & 21.2 & 20 & 3.5 & 6.5 & 0 & 4.5 & 0 \\
\hline 1,2,3-Trichloropropane & 0 & 0 & 0 & 0 & 0 & 0 & 0 & 0 \\
\hline Total Trihalomethanes & ND & 40 & ND & NA & NA & 0 & 0 & ND \\
\hline 1,2.4-Trimethylbenzene & 0 & 0 & 11.1 & 0.1 & 0 & 0 & 77.3 & 0 \\
\hline 1,3.5-Trimethylbenzene & 0 & 0 & 11.1 & 0.1 & 0 & 0 & 72.7 & 0 \\
\hline Vinyl chloride & 0 & 0 & 0 & 1.4 & 2.9 & 0 & 0 & 0 \\
\hline$m$-Xylene & ND & 0 & 0 & 1.2 & 2.3 & 0 & 0 & 0 \\
\hline$o$-Xylene & 12.5 & 0 & 0 & 2.1 & 2.0 & 0 & 0 & 0 \\
\hline$p$-Xylene & ND & 0 & 0 & 1.3 & 1.4 & 0 & 0 & 0 \\
\hline$m$ - \& p-Xylenes & 25.0 & 0 & 0 & 5.0 & 3.8 & 0 & 0 & ND \\
\hline Xylenes (total) & ND & 25.0 & 0 & 3.7 & 2.2 & 0 & 0 & 0 \\
\hline
\end{tabular}


Appendix 4. Co-occurrence of volatile organic compounds in drinking water for randomly selected community wator systems in the study area, 1993-98-Continued

[Co-occurrence is calculated as the percentage of samples with detections of compound specified by column that also had detections of compound specified by row, for example, 2.2 percent of the drinking-water samples with benzene detections also had bromochlormethane detections when both compounds were analyzed for in the same sample; values shown in bold when co-occurrence equals or exceeds 20 percent of 10 or more detections of compound specified by column; NA, not applicable; ND, no detections of compound specified by column]

\begin{tabular}{|c|c|c|c|c|c|c|c|c|}
\hline \multirow[b]{2}{*}{ voc } & \multicolumn{8}{|c|}{ Co-occurrence, in percent } \\
\hline & $\begin{array}{l}\text { Carbon } \\
\text { disulfide }\end{array}$ & $\begin{array}{l}\text { Carbon } \\
\text { tetrachlo- } \\
\text { ride }\end{array}$ & $\begin{array}{l}\text { Chloro- } \\
\text { dibromo- } \\
\text { methane }\end{array}$ & $\begin{array}{l}\text { Chloro- } \\
\text { ethane }\end{array}$ & $\begin{array}{l}\text { Chloro- } \\
\text { form }\end{array}$ & $\begin{array}{l}\text { Chloro- } \\
\text { methane }\end{array}$ & $\begin{array}{l}\text { o-Chloro- } \\
\text { toluene }\end{array}$ & $\begin{array}{l}\text { p-Chloro- } \\
\text { t-luene }\end{array}$ \\
\hline Acetone & 0 & 0 & 2.0 & 0 & 6.5 & 0 & ND & 0 \\
\hline Benzene & 0 & 5.5 & 0.3 & 0 & 0.5 & 0 & 0 & 0 \\
\hline Bromochloromethane & 0 & 0 & 0.2 & 0 & 0.1 & 0 & 0 & 0 \\
\hline Bromodichloromethane & 0 & 6.2 & 89.3 & 30 & 70.7 & 31.6 & 100 & 60 \\
\hline Bromoform & 0 & 1.0 & 33.3 & 0 & 11.6 & 14.3 & 0 & 60 \\
\hline Bromomethane & 0 & 0 & 0.2 & 0 & 0.1 & 5.6 & 0 & 0 \\
\hline n-Butylbenzene & 0 & 0 & 0.2 & 0 & 0.1 & 0 & 0 & 20 \\
\hline sec-Butylbenzene & 0 & 0 & 0 & 0 & 0 & 0 & 0 & 0 \\
\hline Carbon disulfide & NA & ND & 0 & 0 & 0 & 0 & ND & ND \\
\hline Carbon tetrachloride & 0 & NA & 0.6 & 0 & 1.3 & 0 & 0 & 0 \\
\hline Chlorodibromomethane & 0 & 6.2 & NA & 20 & 42.3 & 27.0 & 66.7 & 25.0 \\
\hline Chloroethane & 0 & 0 & 0.2 & NA & 0.2 & 2.8 & 0 & 0 \\
\hline Chloroform & 0 & 24.7 & 84.4 & 30 & NA & 43.2 & 100 & 60 \\
\hline Chloromethane & 0 & 0 & 1.1 & 10 & 0.8 & NA & 0 & 0 \\
\hline$o$-Chlorotoluene & 0 & 0 & 0.2 & 0 & 0.2 & 0 & NA & 40 \\
\hline$p$-Chlorotoluene & 0 & 0 & 0.1 & 0 & 0.2 & 0 & 66.7 & NA \\
\hline Dibromochloropropane & ND & 0 & 0.3 & 0 & 0.3 & 0 & 0 & 0 \\
\hline Dibromomethane & 0 & 0 & 0.8 & 0 & 0.4 & 0 & 0 & 0 \\
\hline$o$-Dichlorobenzene & 0 & 0 & 0.7 & 0 & 0.5 & 0 & 33.3 & 20 \\
\hline$p$-Dichlorobenzene & 0 & 0 & 0.7 & 0 & 0.5 & 0 & 0 & 0 \\
\hline Dichlorodifluoromethane & 0 & 31.3 & 0.1 & 0 & 0.8 & 0 & 0 & 0 \\
\hline 1,1-Dichloroethane & 0 & 24.2 & 0.9 & 0 & 2.2 & 0 & 0 & 0 \\
\hline 1.2-Dichloroethane & 0 & 5.8 & 2.2 & 0 & 1.7 & 11.1 & 0 & 0 \\
\hline 1,1-Dichloroethene & 0 & 51.7 & 0.6 & 0 & 2.7 & 0 & 0 & 0 \\
\hline cis-1,2-Dichloroethene & 0 & 39.2 & 4.1 & 0 & 4.3 & 0 & 0 & 0 \\
\hline trans-1,2-Dichloroethene & 0 & 1.7 & 0.1 & 0 & 0.2 & 0 & 0 & 0 \\
\hline Dichloromethane & 100 & 4.2 & 1.7 & 0 & 1.3 & 13.9 & 0 & 0 \\
\hline 1,2-Dichloropropane & 0 & 0.8 & 0.7 & 0 & 0.4 & 0 & 0 & 0 \\
\hline 1,3-Dichloropropane & 0 & 0 & 0.1 & 0 & 0.2 & 0 & 0 & 0 \\
\hline 2,2-Dichloropropane & 0 & 0 & 0.1 & 0 & 0 & 0 & 0 & 0 \\
\hline cis-1.3-Dichloropropene & 0 & 0 & 0 & 0 & 0.1 & 0 & 0 & 0 \\
\hline Ethylbenzene & 0 & 1.9 & 3.3 & 10 & 2.1 & 2.8 & 0 & 0 \\
\hline Ethylene dibromide & 0 & 0 & 0 & 0 & 0.1 & 0 & 0 & 0 \\
\hline Fluorotrichloromethane & 0 & 27.3 & 0.2 & 0 & 0.3 & 0 & 0 & 0 \\
\hline Hexachlorobutadiene & 0 & 0 & 0 & 0 & 0 & 0 & 0 & 0 \\
\hline lsopropylbenzene & 0 & 0 & 0 & 0 & 0 & 0 & 0 & 0 \\
\hline
\end{tabular}


Appendix 4. Co-occurrence of volatile organic compounds in drinking water for randomly selected community water systems in the study area, 1993-98-Continued

[Co-occurrence is calculated as the percentage of samples with detections of compound specified by column that also had detections of compound specified by row, for example, 2.2 percent of the drinking-water samples with benzene detections also had bromochlormethane detections when both compounds were analyzed for in the same sample; values shown in bold when co-occurrence equals or exceeds 20 percent of 10 or more detections of compound specified by column; NA, not applicable; ND, no detections of compound specified by column]

\begin{tabular}{|c|c|c|c|c|c|c|c|c|}
\hline \multirow[b]{2}{*}{ voc } & \multicolumn{8}{|c|}{ Co-occurrence, in percent } \\
\hline & $\begin{array}{l}\text { Carbon } \\
\text { disulfide }\end{array}$ & $\begin{array}{l}\text { Carbon } \\
\text { tetrachlo- } \\
\text { ride }\end{array}$ & $\begin{array}{l}\text { Chloro- } \\
\text { dibromo- } \\
\text { methane }\end{array}$ & $\begin{array}{l}\text { Chloro- } \\
\text { ethane }\end{array}$ & $\begin{array}{l}\text { Chloro- } \\
\text { form }\end{array}$ & $\begin{array}{l}\text { Chloro- } \\
\text { methane }\end{array}$ & $\begin{array}{l}\text { o-Chloro- } \\
\text { toluene }\end{array}$ & $\begin{array}{l}\text { p-Chloro- } \\
\text { tc'uene }\end{array}$ \\
\hline$p$-Isopropyltoluene & 0 & 0 & 0 & 0 & 0 & 0 & 0 & 0 \\
\hline Methyl ethyl ketone & 0 & 0 & 1.3 & 0 & 2.2 & 0 & ND & 50 \\
\hline Methyl isobutyl ketone & 0 & 0 & 1.0 & 0 & 1.2 & 0 & ND & ND \\
\hline Methyl tert-butyl ether & 0 & 0 & 5.9 & 37.5 & 5.3 & 7.7 & 0 & 33.3 \\
\hline Monochlorobenzene & 0 & 0 & 0 & 0 & 0.2 & 0 & 0 & 0 \\
\hline Naphthalene & 0 & 0 & 0.1 & 0 & 0 & 0 & 0 & 0 \\
\hline$n$-Propylbenzene & 0 & 0 & 0.1 & 0 & 0.1 & 0 & 33.3 & 0 \\
\hline Styrene & 0 & 1.9 & 0 & 0 & 0 & 0 & 0 & 0 \\
\hline 1,1,1,2-Tetrachloroethane & 0 & 0 & 0 & 0 & 0.1 & 0 & 0 & 0 \\
\hline 1,1,2,2-Tetrachloroethane & 0 & 0 & 0 & 0 & 0 & 0 & 0 & 0 \\
\hline Tetrachloroethylene & 0 & 72.5 & 6.3 & 0 & 7.4 & 0 & 0 & 0 \\
\hline Tetrahydrofuran & 0 & ND & 0 & 0 & 0 & 0 & ND & 0 \\
\hline Toluene & 100 & 0.9 & 2.0 & 20 & 1.9 & 2.8 & 33.3 & 20 \\
\hline 1,2,3-Trichlorobenzene & 0 & 0 & 0 & 0 & 0 & 0 & 0 & 0 \\
\hline 1,2,4-Trichlorobenzene & 0 & 0 & 0.1 & 0 & 0.1 & 0 & 0 & 0 \\
\hline 1,1,1-Trichloroethane & 0 & 65.0 & 2.2 & 0 & 7.3 & 0 & 0 & 0 \\
\hline 1,1,2-Trichloroethane & 0 & 0.8 & 0.1 & 0 & 0.2 & 2.8 & 0 & 0 \\
\hline Trichloroethylene & 0 & 75.4 & 4.6 & 0 & 6.3 & 0 & 0 & 0 \\
\hline 1,2,3-Trichloropropane & 0 & 0 & 0 & 0 & 0.1 & 0 & 0 & 0 \\
\hline Total Trihalomethanes & ND & ND & NA & 0 & NA & 27.3 & ND & ND \\
\hline 1,2,4-Trimethylbenzene & 0 & 0 & 0.1 & 0 & 0.2 & 0 & 0 & 0 \\
\hline 1,3,5-Trimethylbenzene & 0 & 0 & 0.1 & 0 & 0.2 & 0 & 0 & 0 \\
\hline Vinyl chloride & 0 & 1.7 & 1.8 & 0 & 0.9 & 0 & 0 & 0 \\
\hline$m$-Xylene & ND & 0 & 1.6 & ND & 1.2 & 0 & 0 & 0 \\
\hline$o$-Xylene & 0 & 0 & 2.4 & 12.5 & 1.7 & 3.2 & 0 & 0 \\
\hline$p$-Xylene & ND & 0 & 1.7 & ND & 1.1 & 0 & 0 & 0 \\
\hline$m$-\& $p$-Xylenes & 0 & 0 & 6.4 & 12.5 & 4.1 & 4.8 & ND & 0 \\
\hline Xylenes (total) & ND & 3.4 & 3.6 & 0 & 3.0 & 0 & 0 & 0 \\
\hline
\end{tabular}


Appendix 4. Co-occurrence of volatile organic compounds in drinking water for randomly selected community wat?r systems in the study area, 1993-98-Continued

[Co-occurrence is calculated as the percentage of samples with detections of compound specified by column that also had detections of compound specified by row, for example, 2.2 percent of the drinking-water samples with benzene detections also had bromochlormethane detections when both compounds were analyzed for in the same sample; values shown in bold when co-occurrence equals or exceeds 20 percent of 10 or more detactions of compound specified by column; NA, not applicable; ND, no detections of compound specified by column]

\begin{tabular}{|c|c|c|c|c|c|c|c|c|}
\hline \multirow[b]{2}{*}{ voc } & \multicolumn{8}{|c|}{ Co-occurrence, in percent } \\
\hline & $\begin{array}{c}\text { Dibromo- } \\
\text { chloro- } \\
\text { propane }\end{array}$ & $\begin{array}{l}\text { Dibromo- } \\
\text { methane }\end{array}$ & $\begin{array}{c}- \\
\text { Dichloro- } \\
\text { benzene }\end{array}$ & $\begin{array}{c}p- \\
\text { Dichloro- } \\
\text { benzene }\end{array}$ & $\begin{array}{l}\text { Dichloro- } \\
\text { difluoro- } \\
\text { methane }\end{array}$ & $\begin{array}{c}\begin{array}{c}1,1- \\
\text { Dichloro- } \\
\text { ethane }\end{array} \\
\end{array}$ & $\begin{array}{c}1,2- \\
\text { Dichioro- } \\
\text { ethane }\end{array}$ & $\begin{array}{l}\text { 1,^-Dichlo- } \\
\text { rnethene }\end{array}$ \\
\hline Acetone & ND & 0 & ND & 0 & ND & 0 & 0 & 0 \\
\hline Benzene & 0 & 0 & 0 & 0 & 2.1 & 0.7 & 2.7 & 1.0 \\
\hline Bromochloromethane & 0 & 5.6 & 0 & 0 & 0 & 0 & 0 & 0 \\
\hline Bromodichloromethane & 66.7 & 27.3 & 37.5 & 50 & 1.0 & 1.6 & 25.0 & 1.3 \\
\hline Bromoform & 25.0 & 63.6 & 18.8 & 27.8 & 0.5 & 1.2 & 8.3 & 0.8 \\
\hline Bromomethane & 0 & 0 & 0 & 0 & 0 & 0 & 0 & 0 \\
\hline n-Butylbenzene & 50 & 0 & 12.5 & 4.5 & 1.1 & 0 & 0 & 0 \\
\hline sec-Butylbenzene & 0 & 0 & 0 & 0 & 0 & 0 & 0 & 0 \\
\hline Carbon disulfide & ND & ND & ND & ND & ND & 0 & 0 & 0 \\
\hline Carbon tetrachloride & 0 & 0 & 0 & 0 & 15.6 & 5.5 & 6.0 & 14.3 \\
\hline Chlorodibromomethane & 50 & 63.6 & 37.5 & 35.3 & 0.5 & 1.9 & 18.3 & 1.3 \\
\hline Chloroethane & 0 & 0 & 0 & 0 & 0 & 0 & 0 & 0 \\
\hline Chloroform & 66.7 & 72.7 & 56.3 & 52.9 & 7.0 & 10 & 30.6 & 12.4 \\
\hline Chloromethane & 0 & 0 & 0 & 0 & 0 & 0 & 3.8 & 0 \\
\hline$o$-Chlorotoluene & 0 & 0 & 6.3 & 0 & 0 & 0 & 0 & 0 \\
\hline$p$-Chlorotoluene & 0 & 0 & 6.3 & 0 & 0 & 0 & 0 & 0 \\
\hline Dibromochloropropane & NA & 0 & 7.1 & 6.7 & 0 & 0 & 0 & 0 \\
\hline Dibromomethane & 0 & NA & 0 & 0 & 0 & 0 & 1.0 & 0 \\
\hline$o$-Dichlorobenzene & 12.5 & 0 & NA & 2.8 & 0 & 0 & 0 & 0 \\
\hline$p$-Dichlorobenzene & 12.5 & 0 & 6.3 & NA & 0.5 & 0 & 0 & 1.0 \\
\hline Dichlorodifluoromethane & 0 & 0 & 0 & 4.8 & NA & 5.6 & 2.9 & 15.0 \\
\hline 1,1-Dichloroethane & 0 & 0 & 0 & 0 & 12.1 & NA & 12.0 & 60.4 \\
\hline 1,2-Dichloroethane & 0 & 5.6 & 0 & 0 & 1.5 & 3.0 & NA & 5.1 \\
\hline 1,1-Dichloroethene & 0 & 0 & 0 & 12.1 & 28.6 & 55.1 & 20.2 & NA \\
\hline cis-1,2-Dichloroethene & 0 & 5.6 & 0 & 5.7 & 55.8 & 36.1 & 28.9 & 44.7 \\
\hline trans-1,2-Dichloroethene & 0 & 0 & 0 & 2.9 & 0.5 & 0 & 0.9 & 1.0 \\
\hline Dichloromethane & 0 & 0 & 0 & 5.9 & 2.0 & 0.9 & 6.0 & 2.4 \\
\hline 1,2-Dichloropropane & 0 & 0 & 0 & 2.9 & 0 & 0.9 & 8.8 & 1.2 \\
\hline 1,3-Dichloropropane & 0 & 0 & 0 & 0 & 0 & 0.7 & 2.9 & 1.0 \\
\hline 2.2-Dichloropropane & 0 & 0 & 0 & 0 & 1.0 & 0.2 & 0 & 0.5 \\
\hline cis-1,3-Dichloropropene & 0 & 0 & 0 & 0 & 0 & 0 & 0 & 0 \\
\hline Ethylbenzene & 0 & 0 & 0 & 2.8 & 0 & 0 & 0.9 & 0.2 \\
\hline Ethylene dibromide & 89.3 & 0 & 0 & 0 & 0 & 0 & 4.6 & 0 \\
\hline Fluorotrichloromethane & 0 & 0 & 0 & 0 & 17.2 & 5.1 & 2.0 & 11.5 \\
\hline Hexachlorobutadiene & 0 & 0 & 0 & 0 & 0 & 0 & 0 & 0 \\
\hline Isopropylbenzene & 0 & 0 & 0 & 0 & 0 & 0 & 0 & 0 \\
\hline
\end{tabular}


Appendix 4. Co-occurrence of volatile organic compounds in drinking water for randomly selected community water systems in the study area, 1993-98-Continued

[Co-occurrence is calculated as the percentage of samples with detections of compound specified by column that also had detections of compound specified by row, for example, 2.2 percent of the drinking-water samples with benzene detections also had bromochlormethane detections when both compounds were analyzed for in the same sample; values shown in bold when co-occurrence equals or exceeds 20 percent of 10 or more detections of compound specified by column; NA, not applicable; ND, no detections of compound specified by column]

\begin{tabular}{|c|c|c|c|c|c|c|c|c|}
\hline \multirow[b]{2}{*}{ voc } & \multicolumn{8}{|c|}{ Co-occurrence, in percent } \\
\hline & $\begin{array}{c}\text { Dibromo- } \\
\text { chloro- } \\
\text { propane }\end{array}$ & $\begin{array}{l}\text { Dibromo- } \\
\text { methane }\end{array}$ & $\begin{array}{c}0- \\
\text { Dichloro- } \\
\text { benzene }\end{array}$ & $\begin{array}{c}p- \\
\text { Dichloro- } \\
\text { benzene }\end{array}$ & $\begin{array}{l}\text { Dichloro- } \\
\text { difluoro- } \\
\text { methane }\end{array}$ & $\begin{array}{c}1,1- \\
\text { Dichloro- } \\
\text { ethane }\end{array}$ & $\begin{array}{c}1,2- \\
\text { Dichloro- } \\
\text { ethane }\end{array}$ & $\begin{array}{l}\text { 1,1-Dichlo- } \\
\text { ro:thene }\end{array}$ \\
\hline$p$-Isopropyltoluene & 0 & 0 & 0 & 0 & 0 & 0 & 1.0 & 0.3 \\
\hline Methyl ethyl ketone & 0 & 0 & ND & 0 & 0 & 0 & 0 & 0 \\
\hline Methyl isobutyl ketone & ND & 0 & ND & 0 & ND & 0 & 0 & 0 \\
\hline Methyl tert-butyl ether & 0 & 0 & 0 & 0 & 0 & 10.4 & 4.0 & 6.7 \\
\hline Monochlorobenzene & 0 & 0 & 0 & 0 & 1.1 & 3.0 & 0 & 3.2 \\
\hline Naphthalene & 0 & 0 & 0 & 0 & 0 & 0 & 1.4 & 0 \\
\hline$n$-Propylbenzene & 0 & 0 & 0 & 0 & 0 & 0 & 0 & 0 \\
\hline Styrene & 0 & 0 & 0 & 0 & 0 & 0 & 0 & 0 \\
\hline 1,1,1,2-Tetrachloroethane & 0 & 0 & 0 & 0 & 0 & 0 & 0 & 0 \\
\hline 1,1,2,2-Tetrachloroethane & 0 & 0 & 0 & 0 & 0 & 0 & 0 & 0 \\
\hline Tetrachloroethylene & 0 & 5.6 & 0 & 2.9 & 84.4 & 61.1 & 35.9 & 73.3 \\
\hline Tetrahydrofuran & ND & ND & ND & 0 & ND & 0 & 0 & 0 \\
\hline Toluene & 0 & 0 & 0 & 0 & 0 & 0.2 & 7.1 & 0 \\
\hline 1,2.3-Trichlorobenzene & 0 & 0 & 0 & 0 & 0 & 0 & 0 & 0 \\
\hline 1,2,4-Trichlorobenzene & 12.5 & 0 & 12.5 & 2.8 & 0 & 0 & 0 & 0 \\
\hline 1,1,1-Trichloroethane & 0 & 0 & 0 & 31.4 & 29.1 & 79.5 & 32.5 & 86.9 \\
\hline 1,1,2-Trichloroethane & 0 & 0 & 0 & 0 & 0.5 & 0.2 & 0.9 & 0.5 \\
\hline Trichloroethylene & 12.5 & 0 & 6.3 & 20.6 & 82.9 & 66.8 & 41.9 & 81.5 \\
\hline 1,2,3-Trichloropropane & 0 & 0 & 0 & 0 & 0 & 4.3 & 2.9 & 3.8 \\
\hline Total Trihalomethanes & 100 & ND & ND & 0 & ND & 0 & 28.6 & 0 \\
\hline 1,2,4-Trimethylbenzene & 0 & 0 & 0 & 0 & 1.1 & 0 & 0 & 0 \\
\hline 1,3,5-Trimethylbenzene & 0 & 0 & 6.3 & 0 & 0.5 & 0 & 0 & 0 \\
\hline Vinyl chloride & 0 & 0 & 6.3 & 0 & 3.5 & 6.1 & 0 & 7.1 \\
\hline$m$-Xylene & 0 & 0 & 0 & 0 & 0 & 0 & 1.3 & 0 \\
\hline$o$-Xylene & 0 & 0 & 0 & 9.5 & 0 & 0 & 1.1 & 0 \\
\hline$p$-Xylene & 0 & 0 & 0 & 0 & 0 & 0 & 1.3 & 0 \\
\hline$m$ - \& $p$-Xylenes & ND & 0 & 0 & 0 & ND & 0 & 0 & 2.7 \\
\hline Xylenes (total) & 0 & 0 & 12.5 & 3.3 & 0 & 0 & 5.8 & 0 \\
\hline
\end{tabular}


Appendix 4. Co-occurrence of volatile organic compounds in drinking water for randomly selected community wator systems in the study area, 1993-98-Continued

[Co-occurrence is calculated as the percentage of samples with detections of compound specified by column that also had detections of comoound specified by row, for example, 2.2 percent of the drinking-water samples with benzene detections also had bromochlormethane detections when both compounds were analyzed for in the same sample; values shown in bold when co-occurrence equals or exceeds 20 percent of 10 or more detections of compound specified by column; NA, not applicable; ND, no detections of compound specified by column]

\begin{tabular}{|c|c|c|c|c|c|c|c|c|}
\hline \multirow[b]{2}{*}{ voc } & \multicolumn{8}{|c|}{ Co-occurrence, in percent } \\
\hline & $\begin{array}{l}\text { cis-1,2- } \\
\text { Dichloro- } \\
\text { ethene }\end{array}$ & $\begin{array}{l}\text { trans-1,2- } \\
\text { Dichloro- } \\
\text { ethene }\end{array}$ & $\begin{array}{l}\text { Dichloro- } \\
\text { methane }\end{array}$ & $\begin{array}{c}\text { 1,2- } \\
\text { Dichloro- } \\
\text { propane }\end{array}$ & $\begin{array}{c}\text { 1,3- } \\
\text { Dichloro- } \\
\text { propane }\end{array}$ & $\begin{array}{c}\text { 2,2- } \\
\text { Dichloro- } \\
\text { propane }\end{array}$ & $\begin{array}{l}\text { cis-1,3- } \\
\text { Dichloro- } \\
\text { propene }\end{array}$ & $\begin{array}{l}\text { Ethy- } \\
\text { banzene }\end{array}$ \\
\hline Acetone & 0 & ND & 10 & 0 & ND & ND & ND & 0 \\
\hline Benzene & 1.1 & 0 & 0.9 & 1.2 & 0 & 0 & 0 & 3.7 \\
\hline Bromochloromethane & 0.2 & 0 & 0 & 0 & 0 & 0 & 0 & 0 \\
\hline Bromodichloromethane & 7.1 & 9.1 & 24.1 & 8.8 & 50 & 0 & 0 & 57.6 \\
\hline Bromoform & 4.6 & 9.1 & 14.5 & 3.7 & 10 & 0 & 0 & 14.0 \\
\hline Bromomethane & 0.2 & 0 & 0 & 0 & 0 & 0 & 0 & 0 \\
\hline$n$-Butylbenzene & 0 & 0 & 0 & 0 & 0 & 0 & 0 & 1.8 \\
\hline sec-Butylbenzene & 0 & 0 & 0 & 0 & 0 & 0 & 0 & 0 \\
\hline Carbon disulfide & ND & ND & 11.1 & ND & ND & ND & ND & ND \\
\hline Carbon tetrachloride & 7.2 & 7.4 & 4.3 & 1.2 & 0 & 0 & 0 & 2.5 \\
\hline Chlorodibromomethane & 6.6 & 9.1 & 19.3 & 7.4 & 10 & 25.0 & 0 & 51.7 \\
\hline Chloroethane & 0 & 0 & 0 & 0 & 0 & 0 & 0 & 1.8 \\
\hline Chloroform & 14.6 & 36.4 & 30.1 & 8.6 & 40 & 0 & 100 & 67.8 \\
\hline Chloromethane & 0 & 0 & 5.7 & 0 & 0 & 0 & 0 & 1.9 \\
\hline$o$-Chlorotoluene & 0 & 0 & 0 & 0 & 0 & 0 & 0 & 0 \\
\hline$p$-Chlorotoluene & 0 & 0 & 0 & 0 & 0 & 0 & 0 & 0 \\
\hline Dibromochloropropane & 0 & 0 & 0 & 0 & 0 & 0 & 0 & 0 \\
\hline Dibromomethane & 0.2 & 0 & 0 & 0 & 0 & 0 & 0 & 0 \\
\hline$o$-Dichlorobenzene & 0 & 0 & 0 & 0 & 0 & 0 & 0 & 0 \\
\hline$p$-Dichlorobenzene & 0.3 & 3.7 & 1.8 & 1.2 & 0 & 0 & 0 & 1.3 \\
\hline Dichlorodifluoromethane & 18.9 & 10 & 4.9 & 0 & 0 & 50 & 0 & 0 \\
\hline 1,1-Dichloroethane & 26.2 & 0 & 4.5 & 4.9 & 30 & 25.0 & 0 & 0 \\
\hline 1,2-Dichloroethane & 5.0 & 3.7 & 6.0 & 12.0 & 30 & 0 & 0 & 1.3 \\
\hline 1.1-Dichloroethene & 30.3 & 14.8 & 8.5 & 6.0 & 40 & 50 & 0 & 1.5 \\
\hline cis-1,2-Dichloroethene & NA & 44.4 & 8.5 & 1.2 & 50 & 75.0 & 0 & 2.5 \\
\hline trans-1,2-Dichloroethene & 1.8 & NA & 0.9 & 0 & 0 & 0 & 0 & 0 \\
\hline Dichloromethane & 1.5 & 3.7 & NA & 0 & 0 & 0 & 0 & 2.5 \\
\hline 1,2-Dichloropropane & 0.2 & 0 & 0 & NA & 22.2 & 0 & 0 & 1.3 \\
\hline 1.3-Dichloropropane & 0.8 & 0 & 0 & 2.5 & NA & 25.0 & 0 & 0 \\
\hline 2,2-Dichloropropane & 0.5 & 0 & 0 & 0 & 14.3 & NA & 0 & 0 \\
\hline cis-1,3-Dichloropropene & 0 & 0 & 0 & 0 & 0 & 0 & NA & 0 \\
\hline Ethylbenzene & 0.3 & 0 & 1.8 & 1.2 & 0 & 0 & 0 & NA \\
\hline Ethylene dibromide & 0 & 0 & 8.3 & 0 & 0 & 0 & 0 & 0 \\
\hline Fluorotrichloromethane & 7.8 & 0 & 2.4 & 0 & 0 & 0 & 0 & 0 \\
\hline Hexachlorobutadiene & 0 & 0 & 0 & 0 & 0 & 0 & 0 & 0 \\
\hline Isopropylbenzene & 0 & 0 & 0 & 0 & 0 & 0 & 0 & 0 \\
\hline
\end{tabular}


Appendix 4. Co-occurrence of volatile organic compounds in drinking water for randomly selected community water systems in the study area, 1993-98-Continued

[Co-occurrence is calculated as the percentage of samples with detections of compound specified by column that also had detections of comprund specified by row, for example, 2.2 percent of the drinking-water samples with benzene detections also had bromochlormethane detections wh?n both compounds were analyzed for in the same sample; values shown in bold when co-occurrence equals or exceeds 20 percent of 10 or more detections of compound specified by column; NA, not applicable; ND, no detections of compound specified by column]

\begin{tabular}{|c|c|c|c|c|c|c|c|c|}
\hline \multirow[b]{2}{*}{ voc } & \multicolumn{8}{|c|}{ Co-occurrence, in percent } \\
\hline & $\begin{array}{l}\text { cis-1,2- } \\
\text { Dichloro- } \\
\text { ethene }\end{array}$ & $\begin{array}{l}\text { trans-1,2- } \\
\text { Dichloro- } \\
\text { ethene }\end{array}$ & $\begin{array}{l}\text { Dichloro- } \\
\text { methane }\end{array}$ & $\begin{array}{c}1,2- \\
\text { Dichloro- } \\
\text { propane }\end{array}$ & $\begin{array}{c}1,3- \\
\text { Dichloro- } \\
\text { propane }\end{array}$ & $\begin{array}{c}\text { 2,2- } \\
\text { Dichloro- } \\
\text { propane }\end{array}$ & $\begin{array}{l}\text { cis-1,3- } \\
\text { Dichloro- } \\
\text { propene }\end{array}$ & $\begin{array}{c}\text { E.thyl- } \\
\text { benzene }\end{array}$ \\
\hline$p$-Isopropyltoluene & 0 & 0 & 0 & 0 & 0 & 0 & 0 & 0 \\
\hline Methyl ethyl ketone & 0 & ND & 0 & 0 & ND & ND & ND & 0 \\
\hline Methyl isobutyl ketone & 0 & ND & 0 & 0 & ND & ND & ND & 50 \\
\hline Methyl tert-butyl ether & 22.4 & 0 & 7.7 & 0 & 0 & ND & ND & 5.7 \\
\hline Monochlorobenzene & 2.0 & 0 & 0 & 0 & 0 & 0 & 0 & 0 \\
\hline Naphthalene & 0 & 0 & 1.4 & 0 & 0 & 0 & 0 & 1.9 \\
\hline n-Propylbenzene & 0 & 0 & 0 & 0 & 0 & 0 & 0 & 1.8 \\
\hline Styrene & 0.2 & 0 & 0.9 & 0 & 0 & 0 & 0 & 2.5 \\
\hline 1,1,1,2-Tetrachloroethane & 0 & 0 & 0 & 0 & 0 & 0 & 0 & 0 \\
\hline 1,1,2,2-Tetrachloroethane & 0 & 0 & 0 & 0 & 0 & 0 & 0 & 0 \\
\hline Tetrachloroethylene & 68.3 & 63.0 & 12.0 & 20.5 & 50 & 100 & 0 & 3.8 \\
\hline Tetrahydrofuran & 0 & ND & 0 & 0 & ND & ND & ND & 0 \\
\hline Toluene & 0.5 & 3.7 & 5.3 & 2.4 & 10 & 0 & 0 & 36.6 \\
\hline 1,2,3-Trichlorobenzene & 0 & 0 & 0 & 0 & 0 & 0 & 0 & 0 \\
\hline 1,2,4-Trichlorobenzene & 0 & 0 & 0 & 0 & 0 & 0 & 0 & 0 \\
\hline 1,1,1-Trichloroethane & 44.3 & 37.0 & 14.5 & 6.0 & 40 & 50 & 0 & 5.0 \\
\hline 1,1,2-Trichloroethane & 0.2 & 0 & 0.9 & 0 & 0 & 0 & 0 & 1.3 \\
\hline Trichloroethylene & 85.3 & 63.0 & 19.1 & 20.5 & 40 & 100 & 0 & 3.8 \\
\hline 1,2,3-Trichloropropane & 0.5 & 0 & 0 & 24.7 & 0 & 0 & 0 & 0 \\
\hline Total Trihalomethanes & 0 & ND & 40.9 & 0 & ND & ND & ND & 88.9 \\
\hline 1.2,4-Trimethylbenzene & 0 & 0 & 0 & 0 & 0 & 0 & 0 & 3.5 \\
\hline 1,3,5-Trimethylbenzene & 0 & 0 & 0 & 0 & 0 & 0 & 0 & 3.5 \\
\hline Vinyl chloride & 9.2 & 8.0 & 0 & 0 & 0 & 0 & 0 & 0 \\
\hline$m$-Xylene & 0 & 0 & 8.8 & 0 & 0 & 0 & ND & 38.9 \\
\hline$o$-Xylene & 0 & 0 & 5.8 & 0 & 0 & 0 & 0 & 47.6 \\
\hline$p$-Xylene & 0 & 0 & 0 & 0 & 0 & 0 & 0 & 26.7 \\
\hline$m$ - \& p-Xylenes & 0 & ND & 0 & 33.3 & ND & ND & ND & 45.8 \\
\hline Xylenes (total) & 0 & 0 & 1.3 & 0 & 0 & 0 & 0 & 73.1 \\
\hline
\end{tabular}


Appendix 4. Co-occurrence of volatile organic compounds in drinking water for randomly selected community water systems in the study area, 1993-98-Continued

[Co-occurrence is calculated as the percentage of samples with detections of compound specified by column that also had detections of com?ound specified by row, for example, 2.2 percent of the drinking-water samples with benzene detections also had bromochlormethane detections when both compounds were analyzed for in the same sample; values shown in bold when co-occurrence equals or exceeds 20 percent of 10 or more detections of compound specified by column; NA, not applicable; ND, no detections of compound specified by column]

\begin{tabular}{|c|c|c|c|c|c|c|c|c|}
\hline \multirow[b]{2}{*}{ voc } & \multicolumn{8}{|c|}{ Co-occurrence, in percent } \\
\hline & $\begin{array}{l}\text { Ethylene } \\
\text { dibromide }\end{array}$ & $\begin{array}{l}\text { Fluoro- } \\
\text { trichloro- } \\
\text { methane }\end{array}$ & $\begin{array}{l}\text { Hexachlor } \\
\text { o-butadi- } \\
\text { ene }\end{array}$ & $\begin{array}{l}\text { Isopropyl- } \\
\text { benzene }\end{array}$ & $\begin{array}{l}\text { p-lso- } \\
\text { propyl- } \\
\text { toluene }\end{array}$ & $\begin{array}{l}\text { Methyl } \\
\text { ethyl } \\
\text { ketone }\end{array}$ & $\begin{array}{l}\text { Methyl } \\
\text { isobutyl } \\
\text { ketone }\end{array}$ & $\begin{array}{l}\text { Methyl tert- } \\
\text { butyl ether }\end{array}$ \\
\hline Acetone & ND & ND & ND & ND & ND & 0 & 0 & 0 \\
\hline Benzene & 0 & 9.1 & 0 & 100 & 0 & 0 & 0 & 2.4 \\
\hline Bromochloromethane & 0 & 0 & 0 & 0 & 0 & 0 & 0 & 0 \\
\hline Bromodichloromethane & 12.5 & 3.6 & 0 & 0 & 0 & 57.1 & 100 & 11.5 \\
\hline Bromoform & 14.3 & 1.8 & 0 & 0 & 0 & 12.5 & 50 & 5.1 \\
\hline Bromomethane & 0 & 0 & 0 & 0 & 0 & 0 & 0 & 0 \\
\hline$n$-Butylbenzene & 0 & 0 & 0 & 0 & 66.7 & 0 & 0 & 0 \\
\hline sec-Butylbenzene & 0 & 0 & 0 & 0 & 0 & 0 & 0 & 0 \\
\hline Carbon disulfide & ND & ND & $\mathrm{ND}$ & ND & ND & 0 & ND & 0 \\
\hline Carbon tetrachloride & 0 & 48.2 & 0 & 0 & 0 & 0 & 0 & 0 \\
\hline Chlorodibromomethane & 0 & 3.6 & 0 & 0 & 0 & 25.0 & 50 & 8.1 \\
\hline Chloroethane & 0 & 0 & 0 & 0 & 0 & 0 & 0 & 0.9 \\
\hline Chloroform & 12.5 & 10.7 & 0 & 0 & 0 & 62.5 & 100 & 14.1 \\
\hline Chloromethane & 0 & 0 & 0 & 0 & 0 & 0 & 0 & 0.6 \\
\hline$o$-Chlorotoluene & 0 & 0 & 0 & 0 & 0 & 0 & 0 & 0 \\
\hline$p$-Chlorotoluene & 0 & 0 & 0 & 0 & 0 & 14.3 & 0 & 0 \\
\hline Dibromochloropropane & 75.8 & 0 & ND & 0 & ND & 0 & 0 & 0 \\
\hline Dibromomethane & 0 & 0 & 0 & 0 & 0 & 0 & 0 & 0 \\
\hline$o$-Dichlorobenzene & 0 & 0 & 0 & 0 & 0 & 0 & 0 & 0 \\
\hline$p$-Dichlorobenzene & 0 & 0 & 0 & 0 & 0 & 0 & 0 & 0 \\
\hline Dichlorodifluoromethane & 0 & 60.7 & 0 & 0 & 0 & 0 & 0 & 0 \\
\hline 1,1-Dichloroethane & 0 & 39.3 & 0 & 0 & 0 & 0 & 0 & 5.1 \\
\hline 1,2-Dichloroethane & 27.3 & 3.6 & 0 & 0 & 16.7 & 0 & 0 & 0.6 \\
\hline 1,1-Dichloroethene & 0 & 80 & 0 & 0 & 16.7 & 0 & 0 & 2.4 \\
\hline cis-1,2-Dichloroethene & 0 & 78.6 & 0 & 0 & 0 & 0 & 0 & 11.8 \\
\hline trans-1,2-Dichloroethene & 0 & 0 & 0 & 0 & 0 & 0 & 0 & 0 \\
\hline Dichloromethane & 33.3 & 3.6 & 0 & 0 & 0 & 0 & 0 & 0.9 \\
\hline 1.2-Dichloropropane & 0 & 0 & 0 & 0 & 0 & 0 & 0 & 0 \\
\hline 1,3-Dichloropropane & 0 & 0 & 0 & 0 & 0 & 0 & 0 & 0 \\
\hline 2,2-Dichloropropane & 0 & 0 & 0 & 0 & 0 & 0 & 0 & 0 \\
\hline cis-1,3-Dichloropropene & 0 & 0 & 0 & 0 & 0 & 0 & 0 & 0 \\
\hline Ethylbenzene & 0 & 0 & 0 & 0 & 0 & 0 & 100 & 0.6 \\
\hline Ethylene dibromide & NA & 0 & ND & 0 & ND & 0 & 0 & 0 \\
\hline Fluorotrichloromethane & 0 & NA & 0 & 0 & 0 & 0 & 0 & 0.6 \\
\hline Hexachlorobutadiene & 0 & 0 & NA & 0 & 0 & 0 & 0 & 0 \\
\hline Isopropylbenzene & 0 & 0 & 0 & NA & 0 & 0 & 0 & 0.3 \\
\hline
\end{tabular}


Appendix 4. Co-occurrence of volatile organic compounds in drinking water for randomly selected community wat $\epsilon$, systems in the study area, 1993-98-Continued

[Co-occurrence is calculated as the percentage of samples with detections of compound specified by column that also had detections of compound specified by row, for example, 2.2 percent of the drinking-water samples with benzene detections also had bromochlormethane detections when both compounds were analyzed for in the same sample; values shown in bold when co-occurrence equals or exceeds 20 percent of 10 or more detertions of compound specified by column; NA, not applicable; ND, no detections of compound specified by column]

\begin{tabular}{|c|c|c|c|c|c|c|c|c|}
\hline \multirow[b]{2}{*}{ VOC } & \multicolumn{8}{|c|}{ Co-occurrence, in percent } \\
\hline & $\begin{array}{l}\text { Ethylene } \\
\text { dibromide }\end{array}$ & $\begin{array}{l}\text { Fluoro- } \\
\text { trichloro- } \\
\text { methane }\end{array}$ & $\begin{array}{l}\text { Hexachlor } \\
\text { o-butadi- } \\
\text { ene }\end{array}$ & $\begin{array}{l}\text { Isopropyl- } \\
\text { benzene }\end{array}$ & $\begin{array}{l}\text { p-Iso- } \\
\text { propyl- } \\
\text { toluene }\end{array}$ & $\begin{array}{l}\text { Methyl } \\
\text { ethyl } \\
\text { ketone }\end{array}$ & $\begin{array}{l}\text { Methyl } \\
\text { isobutyl } \\
\text { ketone }\end{array}$ & $\begin{array}{l}\text { Met'yl tert- } \\
\text { but Il ether }\end{array}$ \\
\hline$p$-Isopropyltoluene & 0 & 0 & 0 & 0 & $\mathrm{NA}$ & 0 & 0 & 0 \\
\hline Methyl ethyl ketone & ND & ND & ND & ND & ND & NA & 0 & 0 \\
\hline Methyl isobutyl ketone & ND & ND & ND & ND & ND & 0 & NA & 0 \\
\hline Methyl tert-butyl ether & 0 & 22.2 & ND & 100 & ND & 0 & 0 & NA \\
\hline Monochlorobenzene & 0 & 9.1 & 0 & 0 & 0 & 0 & 0 & 1.2 \\
\hline Naphthalene & 0 & 0 & 0 & 0 & ND & 0 & 0 & 0.7 \\
\hline$n$-Propylbenzene & 0 & 0 & 0 & 0 & 0 & 0 & 0 & 0 \\
\hline Styrene & 0 & 0 & 0 & 0 & 0 & 0 & 0 & 0 \\
\hline 1,1,1,2-Tetrachloroethane & 0 & 0 & 0 & 0 & 0 & 0 & 0 & 0 \\
\hline 1,1,2,2-Tetrachloroethane & 0 & 0 & 0 & 0 & 0 & 0 & 0 & 0 \\
\hline Tetrachloroethylene & 0 & 76.8 & 0 & 0 & 16.7 & 12.5 & 50 & 16.3 \\
\hline Tetrahydrofuran & ND & ND & ND & ND & ND & 40 & ND & 0 \\
\hline Toluene & 0 & 0 & 0 & 0 & 0 & 0 & 50 & 0.6 \\
\hline 1,2,3-Trichlorobenzene & 0 & 0 & 0 & 0 & 0 & 0 & 0 & 0 \\
\hline 1,2,4-Trichlorobenzene & 0 & 0 & 50 & 0 & 0 & 0 & 0 & 0 \\
\hline 1,1,1-Trichloroethane & 0 & 76.8 & 0 & 0 & 16.7 & 0 & 0 & 10.6 \\
\hline 1,1,2-Trichloroethane & 0 & 0 & 0 & 0 & 0 & 0 & 0 & 0 \\
\hline Trichloroethylene & 33.3 & 87.5 & 0 & 0 & 16.7 & 0 & 0 & 21.4 \\
\hline 1,2,3-Trichloropropane & 0 & 0 & 0 & 0 & 0 & 0 & 0 & 0 \\
\hline Total Trihalomethanes & 0 & 0 & ND & ND & ND & ND & ND & 10.3 \\
\hline $1,2,4$-Trimethylbenzene & 0 & 0 & 0 & 0 & 66.7 & 0 & 0 & 0.3 \\
\hline 1,3,5-Trimethylbenzene & 0 & 0 & 0 & 0 & 83.3 & 0 & 0 & 0 \\
\hline Vinyl chloride & 0 & 14.3 & 0 & 0 & 0 & 0 & 0 & 0.9 \\
\hline$m$-Xylene & 0 & 0 & ND & 0 & 0 & 0 & ND & 0.8 \\
\hline$o$-Xylene & 0 & 0 & 0 & 0 & 0 & 12.5 & 100 & 0.4 \\
\hline$p$-Xylene & 0 & 0 & ND & 0 & 0 & 25.0 & ND & 0.8 \\
\hline$m$ - \& p-Xylenes & ND & 0 & 0 & ND & ND & 0 & 100 & 0 \\
\hline Xylenes (total) & 0 & 0 & 0 & 0 & ND & 20 & ND & 2.7 \\
\hline
\end{tabular}


Appendix 4. Co-occurrence of volatile organic compounds in drinking water for randomly selected community wat I $_{\text {s systems }}$ in the study area, 1993-98-Continued

[Co-occurrence is calculated as the percentage of samples with detections of compound specified by column that also had detections of compound specified by row, for example, 2.2 percent of the drinking-water samples with benzene detections also had bromochlormethane detections when both compounds were analyzed for in the same sample; values shown in bold when co-occurrence equals or exceeds 20 percent of 10 or more detections of compound specified by column; NA, not applicable; ND, no detections of compound specified by column]

\begin{tabular}{|c|c|c|c|c|c|c|c|c|}
\hline \multirow[b]{2}{*}{ voc } & \multicolumn{8}{|c|}{ Co-occurrence, in percent } \\
\hline & $\begin{array}{l}\text { Mono- } \\
\text { chloro- } \\
\text { benzene }\end{array}$ & $\begin{array}{l}\text { Naphtha- } \\
\text { lene }\end{array}$ & $\begin{array}{l}n \text {-Propyl- } \\
\text { benzene }\end{array}$ & Styrene & $\begin{array}{l}1,1,1,2- \\
\text { Tetra- } \\
\text { chloro- } \\
\text { ethane }\end{array}$ & $\begin{array}{l}1,1,2,2- \\
\text { Tetra- } \\
\text { chloro- } \\
\text { ethane }\end{array}$ & $\begin{array}{l}\text { Tetra- } \\
\text { chloro- } \\
\text { ethylene }\end{array}$ & $\begin{array}{c}\text { Tetra- } \\
\text { hydro- } \\
\text { furan }\end{array}$ \\
\hline Acetone & ND & 0 & ND & ND & ND & ND & 0 & 0 \\
\hline Benzene & 18.2 & 12.5 & 0 & 0 & 0 & 0 & 0.8 & 0 \\
\hline Bromochloromethane & 0 & 0 & 0 & 0 & 0 & 0 & 0.1 & 0 \\
\hline Bromodichloromethane & 0 & 11.1 & 25.0 & 0 & 0 & 0 & 2.3 & 0 \\
\hline Bromoform & 0 & 0 & 0 & 0 & 0 & 0 & 3.7 & 0 \\
\hline Bromomethane & 0 & 0 & 0 & 0 & 0 & 0 & 0 & 0 \\
\hline$n$-Butylbenzene & 0 & 12.5 & 50 & 0 & 0 & 0 & 0 & 0 \\
\hline sec-Butylbenzene & 0 & 0 & 0 & 0 & 0 & 0 & 0 & 0 \\
\hline Carbon disulfide & ND & ND & ND & ND & ND & ND & 0 & 0 \\
\hline Carbon tetrachloride & 0 & 0 & 0 & 60 & 0 & 0 & 5.5 & 0 \\
\hline Chlorodibromomethane & 0 & 11.1 & 25.0 & 0 & 0 & 0 & 4.1 & 0 \\
\hline Chloroethane & 0 & 0 & 0 & 0 & 0 & 0 & 0 & 0 \\
\hline Chloroform & 22.2 & 0 & 25.0 & 0 & 50 & 0 & 9.9 & 0 \\
\hline Chloromethane & 0 & 0 & 0 & 0 & 0 & 0 & 0 & 0 \\
\hline$o$-Chlorotoluene & 0 & 0 & 25.0 & 0 & 0 & 0 & 0 & 0 \\
\hline$p$-Chlorotoluene & 0 & 0 & 0 & 0 & 0 & 0 & 0 & 0 \\
\hline Dibromochloropropane & 0 & 0 & 0 & 0 & 0 & 0 & 0 & 0 \\
\hline Dibromomethane & 0 & 0 & 0 & 0 & 0 & 0 & 0.1 & 0 \\
\hline$o$-Dichlorobenzene & 0 & 0 & 0 & 0 & 0 & 0 & 0 & 0 \\
\hline$p$-Dichlorobenzene & 0 & 0 & 0 & 0 & 0 & 0 & 0.1 & 0 \\
\hline Dichlorodifluoromethane & 11.1 & 0 & 0 & 0 & 0 & 0 & 12.0 & 0 \\
\hline 1,1-Dichloroethane & 72.2 & 0 & 0 & 0 & 0 & 0 & 18.2 & 0 \\
\hline 1,2-Dichloroethane & 0 & 11.1 & 0 & 0 & 0 & 0 & 2.6 & 0 \\
\hline 1.1-Dichloroethene & 59.1 & 0 & 0 & 0 & 0 & 0 & 19.7 & 0 \\
\hline cis-1,2-Dichloroethene & 59.1 & 0 & 0 & 20 & 0 & 0 & 28.8 & 0 \\
\hline trans-1.2-Dichloroethene & 0 & 0 & 0 & 0 & 0 & 0 & 1.1 & 0 \\
\hline Dichloromethane & 0 & 12.5 & 0 & 20 & 0 & 0 & 0.9 & 0 \\
\hline 1.2-Dichloropropane & 0 & 0 & 0 & 0 & 0 & 0 & 1.1 & 0 \\
\hline 1,3-Dichloropropane & 0 & 0 & 0 & 0 & 0 & 0 & 0.3 & 0 \\
\hline 2,2-Dichloropropane & 0 & 0 & 0 & 0 & 0 & 0 & 0.3 & 0 \\
\hline cis-1,3-Dichloropropene & 0 & 0 & 0 & ND & 0 & 0 & 0 & 0 \\
\hline Ethylbenzene & 0 & 12.5 & 25.0 & 40 & 0 & 0 & 0.2 & 0 \\
\hline Ethylene dibromide & 0 & 0 & 0 & 0 & 0 & 0 & 0 & 0 \\
\hline Fluorotrichloromethane & 22.2 & 0 & 0 & 0 & 0 & 0 & 3.1 & 0 \\
\hline Hexachlorobutadiene & 0 & 0 & 0 & 0 & 0 & 0 & 0.1 & 0 \\
\hline Isopropylbenzene & 0 & 0 & 0 & 0 & 0 & 0 & 0 & 0 \\
\hline
\end{tabular}


Appendix 4. Co-occurrence of volatile organic compounds in drinking water for randomly selected community water systems in the study area, 1993-98-Continued

[Co-occurrence is calculated as the percentage of samples with detections of compound specified by column that also had detections of comprund specified by row, for example, 2.2 percent of the drinking-water samples with benzene detections also had bromochlormethane detections whin both compounds were analyzed for in the same sample; values shown in bold when co-occurrence equals or exceeds 20 percent of 10 or more detertions of compound specified by column; NA, not applicable; ND, no detections of compound specified by column]

\begin{tabular}{|c|c|c|c|c|c|c|c|c|}
\hline \multirow[b]{2}{*}{ VOC } & \multicolumn{8}{|c|}{ Co-occurrence, in percent } \\
\hline & $\begin{array}{l}\text { Mono- } \\
\text { chloro- } \\
\text { benzene }\end{array}$ & $\begin{array}{l}\text { Naphtha- } \\
\text { lene }\end{array}$ & $\begin{array}{l}n \text {-Propyl- } \\
\text { benzene }\end{array}$ & Styrene & $\begin{array}{l}\text { 1,1,1,2- } \\
\text { Tetra- } \\
\text { chloro- } \\
\text { ethane }\end{array}$ & $\begin{array}{c}\text { 1,1,2,2- } \\
\text { Tetra- } \\
\text { chloro- } \\
\text { ethane }\end{array}$ & $\begin{array}{l}\text { Tetra- } \\
\text { chloro- } \\
\text { ethylene }\end{array}$ & $\begin{array}{l}\text { Tetra- } \\
\text { hydro- } \\
\text { firan }\end{array}$ \\
\hline$p$-Isopropyltoluene & 0 & 0 & 0 & 0 & 0 & 0 & 0.1 & 0 \\
\hline Methyl ethyl ketone & ND & 0 & ND & ND & ND & ND & 2.4 & 100 \\
\hline Methyl isobutyl ketone & ND & 0 & ND & ND & ND & ND & 14.3 & 0 \\
\hline Methyl tert-butyl ether & 80 & 40 & 0 & 0 & 0 & 0 & 17.9 & 0 \\
\hline Monochlorobenzene & NA & 0 & 0 & 0 & 0 & 0 & 0.9 & 0 \\
\hline Naphthalene & 0 & NA & 33.3 & 0 & 0 & 0 & 0.2 & 0 \\
\hline n-Propylbenzene & 0 & 12.5 & NA & 0 & 0 & 0 & 0 & 0 \\
\hline Styrene & 0 & 0 & 0 & NA & 0 & 0 & 0.1 & 0 \\
\hline 1,1,1,2-Tetrachloroethane & 0 & 0 & 0 & 0 & NA & 0 & 0 & 0 \\
\hline $1,1,2,2$-Tetrachloroethane & 0 & 0 & 0 & 0 & 0 & NA & 0 & 0 \\
\hline Tetrachloroethylene & 63.6 & 12.5 & 0 & 20 & 0 & 0 & NA & 50 \\
\hline Tetrahydrofuran & ND & ND & ND & ND & ND & ND & 25.0 & NA \\
\hline Toluene & 4.5 & 12.5 & 25.0 & 0 & 0 & 0 & 0.6 & 0 \\
\hline 1,2,3-Trichlorobenzene & 0 & 28.6 & 0 & 0 & 0 & 0 & 0 & 0 \\
\hline 1,2,4-Trichlorobenzene & 0 & 0 & 0 & 0 & 0 & 0 & 0.1 & 0 \\
\hline 1,1,1-Trichloroethane & 59.1 & 12.5 & 0 & 20 & 0 & 100 & 29.5 & 0 \\
\hline 1,1,2-Trichloroethane & 0 & 0 & 0 & 0 & ND & 0 & 0.1 & 0 \\
\hline Trichloroethylene & 68.2 & 0 & 0 & 0 & 0 & 100 & 60.9 & 0 \\
\hline 1,2,3-Trichloropropane & 0 & 0 & 0 & 0 & 0 & 0 & 0.8 & 0 \\
\hline Total Trihalomethanes & $\mathrm{ND}$ & 25.0 & 0 & ND & ND & 0 & 23.1 & ND \\
\hline 1,2,4-Trimethylbenzene & 0 & 25.0 & 50 & 0 & 0 & 0 & 0.1 & 0 \\
\hline 1,3,5-Trimethylbenzene & 0 & 12.5 & 50 & 0 & 0 & 0 & 0.1 & 0 \\
\hline Vinyl chloride & 40.9 & 0 & 0 & 0 & 0 & 0 & 2.1 & 0 \\
\hline$m$-Xylene & 0 & 0 & 0 & 0 & ND & 0 & 0 & ND \\
\hline$o$-Xylene & 0 & 0 & 0 & 0 & ND & 0 & 0.1 & 0 \\
\hline$p$-Xylene & 0 & 0 & 0 & 0 & ND & 0 & 0 & ND \\
\hline$m$-\& $p$-Xylenes & ND & 0 & 0 & ND & ND & ND & 1.0 & 0 \\
\hline Xylenes (total) & 0 & 20 & 0 & 40 & 0 & ND & 0.5 & ND \\
\hline
\end{tabular}


Appendix 4. Co-occurrence of volatile organic compounds in drinking water for randomly selected community water systems in the study area, 1993-98-Continued

[Co-occurrence is calculated as the percentage of samples with detections of compound specified by column that also had detections of comzound specified by row, for example, 2.2 percent of the drinking-water samples with benzene detections also had bromochlormethane detections when both compounds were analyzed for in the same sample; values shown in bold when co-occurrence equals or exceeds 20 percent of 10 or more detections of compound specified by column; NA, not applicable; ND, no detections of compound specified by column]

\begin{tabular}{|c|c|c|c|c|c|c|c|c|}
\hline \multirow[b]{2}{*}{ voc } & \multicolumn{8}{|c|}{ Co-occurrence, in percent } \\
\hline & Toluene & $\begin{array}{c}1,2,3- \\
\text { Trichloro- } \\
\text { benzene }\end{array}$ & $\begin{array}{c}1,2,4- \\
\text { Trichloro- } \\
\text { benzene }\end{array}$ & $\begin{array}{c}1,1,1- \\
\text { Trichloro- } \\
\text { ethane }\end{array}$ & $\begin{array}{c}1,1,2- \\
\text { Trichloro- } \\
\text { ethane }\end{array}$ & $\begin{array}{l}\text { Trichloro- } \\
\text { ethylene }\end{array}$ & $\begin{array}{c}1,2,3- \\
\text { Trichloro- } \\
\text { propane }\end{array}$ & $\begin{array}{l}\text { Trihalo- } \\
\text { mothanes, } \\
\text { total }\end{array}$ \\
\hline Acetone & 0 & ND & ND & 0 & ND & 0 & 0 & ND \\
\hline Benzene & 7.1 & 0 & 0 & 0.6 & 0 & 0.7 & 0 & 1.1 \\
\hline Bromochloromethane & 0 & 0 & 0 & 0 & 0 & 0.1 & 0 & 0 \\
\hline Bromodichloromethane & 24.5 & 0 & 16.7 & 2.8 & 57.1 & 2.9 & 0 & 90 \\
\hline Bromoform & 5.9 & 0 & 16.7 & 1.8 & 0 & 2.3 & 0 & 21.5 \\
\hline Bromomethane & 0 & 0 & 0 & 0 & 0 & 0 & 0 & 0 \\
\hline$n$-Butylbenzene & 0.9 & 0 & 16.7 & 0 & 0 & 0.1 & 0 & 0 \\
\hline sec-Butylbenzene & 0 & 0 & 0 & 0.1 & 0 & 0 & 0 & 0 \\
\hline Carbon disulfide & 16.7 & ND & ND & 0 & ND & ND & ND & ND \\
\hline Carbon tetrachloride & 0.8 & 0 & 0 & 7.2 & 12.5 & 5.4 & 0 & 0 \\
\hline Chlorodibromomethane & 17.8 & 0 & 16.7 & 2.2 & 14.3 & 2.9 & 0 & 56.0 \\
\hline Chloroethane & 1.8 & 0 & 0 & 0 & 0 & 0 & 0 & 0 \\
\hline Chloroform & 35.9 & 0 & 33.3 & 15.1 & 57.1 & 8.4 & 4.3 & 94.3 \\
\hline Chloromethane & 0.9 & 0 & 0 & 0 & 14.3 & 0 & 0 & 1.7 \\
\hline$o$-Chlorotoluene & 0.9 & 0 & 0 & 0 & 0 & 0 & 0 & 0 \\
\hline$p$-Chlorotoluene & 0.9 & 0 & 0 & 0 & 0 & 0 & 0 & 0 \\
\hline Dibromochloropropane & 0 & 0 & 50 & 0 & 0 & 0.3 & 0 & 0.7 \\
\hline Dibromomethane & 0 & 0 & 0 & 0 & 0 & 0 & 0 & 0 \\
\hline$o$-Dichlorobenzene & 0 & 0 & 22.2 & 0 & 0 & 0.1 & 0 & 0 \\
\hline$p$-Dichlorobenzene & 0 & 0 & 11.1 & 1.0 & 0 & 0.4 & 0 & 0 \\
\hline Dichlorodifluoromethane & 0 & 0 & 0 & 6.4 & 14.3 & 11.2 & 0 & 0 \\
\hline 1,1-Dichloroethane & 0.9 & 0 & 0 & 36.8 & 12.5 & 19.4 & 40.4 & 0 \\
\hline 1,2-Dichloroethane & 6.3 & 0 & 0 & 3.5 & 11.1 & 3.0 & 6.4 & 1.9 \\
\hline 1,1-Dichloroethene & 0 & 0 & 0 & 34.3 & 22.2 & 21.5 & 31.9 & 0 \\
\hline cis-1,2-Dichloroethene & 2.3 & 0 & 0 & 27.2 & 11.1 & 34.5 & 6.4 & 0 \\
\hline trans-1,2-Dichloroethene & 0.8 & 0 & 0 & 0.9 & 0 & 1.1 & 0 & 0 \\
\hline Dichloromethane & 4.7 & 0 & 0 & 1.6 & 11.1 & 1.4 & 0 & 4.3 \\
\hline 1.2-Dichloropropane & 1.6 & 0 & 0 & 0.5 & 0 & 1.1 & 42.6 & 0 \\
\hline 1,3-Dichloropropane & 0.9 & 0 & 0 & 0.4 & 0 & 0.3 & 0 & 0 \\
\hline 2,2-Dichloropropane & 0 & 0 & 0 & 0.2 & 0 & 0.3 & 0 & 0 \\
\hline cis-1,3-Dichloropropene & 0 & 0 & 0 & 0 & 0 & 0 & 0 & 0 \\
\hline Ethylbenzene & 23.4 & 0 & 0 & 0.4 & 11.1 & 0.2 & 0 & 8.5 \\
\hline Ethylene dibromide & 0 & 0 & 0 & 0 & 0 & 1.0 & 0 & 0 \\
\hline Fluorotrichloromethane & 0 & 0 & 0 & 4.8 & 0 & 3.3 & 0 & 0 \\
\hline Hexachlorobutadiene & 0 & 0 & 16.7 & 0 & 0 & 0 & 0 & 0 \\
\hline Isopropylbenzene & 0 & 0 & 0 & 0 & 0 & 0 & 0 & 0 \\
\hline
\end{tabular}


Appendix 4. Co-occurrence of volatile organic compounds in drinking water for randomly selected community wate- systems in the study area, 1993-98-Continued

[Co-occurrence is calculated as the percentage of samples with detections of compound specified by column that also had detections of compound specified by row, for example. 2.2 percent of the drinking-water samples with benzene detections also had bromochlormethane detections when both compounds were analyzed for in the same sample; values shown in bold when co-occurrence equals or exceeds 20 percent of 10 or more detections of compound specified by column; NA, not applicable; ND, no detections of compound specified by column]

\begin{tabular}{|c|c|c|c|c|c|c|c|c|}
\hline \multirow[b]{2}{*}{ VOC } & \multicolumn{8}{|c|}{ Co-occurrence, in percent } \\
\hline & Toluene & $\begin{array}{c}\text { 1,2,3- } \\
\text { Trichloro- } \\
\text { benzene }\end{array}$ & $\begin{array}{c}\text { 1,2,4- } \\
\text { Trichloro- } \\
\text { benzene }\end{array}$ & $\begin{array}{c}1,1,1- \\
\text { Trichloro- } \\
\text { ethane }\end{array}$ & $\begin{array}{c}1,1,2- \\
\text { Trichloro- } \\
\text { ethane }\end{array}$ & $\begin{array}{l}\text { Trichloro- } \\
\text { ethylene }\end{array}$ & $\begin{array}{c}\text { 1,2,3- } \\
\text { Trichloro- } \\
\text { propane }\end{array}$ & $\begin{array}{l}\text { Tr'halo- } \\
\text { methanes, } \\
\text { I ital }\end{array}$ \\
\hline$p$-Isopropyltoluene & 0 & 0 & 0 & 0.1 & 0 & 0.1 & 0 & 0 \\
\hline Methyl ethyl ketone & 0 & ND & ND & 0 & ND & 0 & 0 & ND \\
\hline Methyl isobutyl ketone & 7.1 & ND & ND & 0 & ND & 0 & ND & ND \\
\hline Methyl tert-butyl ether & 2.7 & ND & 0 & 8.5 & 0 & 17.3 & 0 & 4.1 \\
\hline Monochlorobenzene & 0.8 & 0 & 0 & 1.2 & 0 & 0.9 & 0 & 0 \\
\hline Naphthalene & 1.1 & 100 & 0 & 0.3 & 0 & 0 & 0 & 0.6 \\
\hline$n$-Propylbenzene & 0.9 & 0 & 0 & 0 & 0 & 0.1 & 0 & 0 \\
\hline Styrene & 0 & 0 & 0 & 0.1 & 0 & 0 & 0 & 0 \\
\hline 1,1,1,2-Tetrachloroethane & 0 & 0 & 0 & 0 & 0 & 0 & 0 & 0 \\
\hline 1,1,2,2-Tetrachloroethane & 0 & 0 & 0 & 0.1 & 0 & 0.1 & 0 & 0 \\
\hline Tetrachloroethylene & 6.9 & 0 & 11.1 & 43.5 & 25.0 & 59.4 & 25.5 & 11.4 \\
\hline Tetrahydrofuran & 0 & ND & ND & 0 & ND & 0 & 0 & ND \\
\hline Toluene & NA & 0 & 0 & 0.3 & 0 & 0.3 & 2.1 & 5.9 \\
\hline 1,2,3-Trichlorobenzene & 0 & NA & 0 & 0 & 0 & 0 & 0 & 0 \\
\hline 1,2.4-Trichlorobenzene & 0 & 0 & NA & 0 & 0 & 0.1 & 0 & 0 \\
\hline 1,1,1-Trichloroethane & 2.4 & 0 & 0 & NA & 25.0 & 37.3 & 44.7 & 1.4 \\
\hline 1,1,2-Trichloroethane & 0 & 0 & 0 & 0.2 & NA & 0.1 & 0 & 0 \\
\hline Trichloroethylene & 3.1 & 0 & 22.2 & 56.6 & 22.2 & NA & 57.4 & 0 \\
\hline 1,2,3-Trichloropropane & 0.9 & 0 & 0 & 2.2 & 0 & 1.8 & NA & 0 \\
\hline Total Trihalomethanes & 64.7 & ND & ND & 8.6 & 0 & 0 & ND & NA \\
\hline 1,2,4-Trimethylbenzene & 1.9 & 0 & 0 & 0.1 & 0 & 0 & 0 & 0 \\
\hline 1,3,5-Trimethylbenzene & 0.9 & 0 & 16.7 & 0 & 0 & 0 & 0 & 0 \\
\hline Vinyl chloride & 0 & 0 & 0 & 2.8 & 0 & 2.0 & 0 & 0 \\
\hline$m$-Xylene & 26.2 & 0 & 0 & 0 & 0 & 0.1 & 0 & 1.6 \\
\hline$o$-Xylene & 14.9 & 0 & 0 & 0 & 0 & 0 & 0 & 4.6 \\
\hline$p$-Xylene & 12.8 & 0 & 0 & 0 & 0 & 0 & 0 & 1.6 \\
\hline$m$ - \& p-Xylenes & 6.7 & ND & ND & 0 & 0 & 0 & ND & 9.9 \\
\hline Xylenes (total) & 32.9 & 0 & 11.1 & 0.4 & 0 & 0.5 & 0 & 17.2 \\
\hline
\end{tabular}


Appendix 4. Co-occurrence of volatile organic compounds in drinking water for randomly selected community wator systems in the study area, 1993-98-Continued

[Co-occurrence is calculated as the percentage of samples with detections of compound specified by column that also had detections of com?ound specified by row, for example, 2.2 percent of the drinking-water samples with benzene detections also had bromochlormethane detections when both compounds were analyzed for in the same sample; values shown in bold when co-occurrence equals or exceeds 20 percent of 10 or more detections of compound specified by column; NA, not applicable; ND, no detections of compound specified by column]

\begin{tabular}{|c|c|c|c|c|c|c|c|c|}
\hline \multirow[b]{2}{*}{ VOC } & \multicolumn{8}{|c|}{ Co-occurrence, in percent } \\
\hline & $\begin{array}{c}1,2,4- \\
\text { Trimethyl- } \\
\text { benzene }\end{array}$ & $\begin{array}{c}1,3,5- \\
\text { Trimethyl- } \\
\text { benzene }\end{array}$ & $\begin{array}{l}\text { Vinyl } \\
\text { chloride }\end{array}$ & $m$-Xylene & o-Xylene & p-Xylene & $\begin{array}{l}m \text { - \& p- } \\
\text { Xylenes }\end{array}$ & $\begin{array}{c}\text { Xylenes, } \\
\text { total }\end{array}$ \\
\hline Acetone & 0 & ND & ND & ND & 14.3 & ND & 14.3 & ND \\
\hline Benzene & 0 & 0 & 0 & 0 & 0 & 0 & 0 & 7.6 \\
\hline Bromochloromethane & 3.8 & 4.3 & 0 & 0 & 0 & 0 & 0 & 0 \\
\hline Bromodichloromethane & 4.0 & 4.3 & 28.8 & 30.4 & 51.3 & 57.1 & 75.0 & 50.8 \\
\hline Bromoform & 0 & 0 & 25.4 & 34.8 & 23.7 & 35.7 & 17.4 & 12.5 \\
\hline Bromomethane & 0 & 0 & 0 & 0 & 0 & 0 & 0 & 0 \\
\hline n-Butylbenzene & 65.4 & 69.6 & 0 & 0 & 0 & 0 & 0 & 0 \\
\hline sec-Butylbenzene & 0 & 0 & 0 & 0 & 0 & 0 & 0 & 0 \\
\hline Carbon disulfide & ND & ND & ND & ND & ND & ND & ND & ND \\
\hline Carbon tetrachloride & 0 & 0 & 3.2 & 0 & 0 & 0 & 0 & 0.9 \\
\hline Chlorodibromomethane & 4.0 & 4.3 & 27.1 & 34.8 & 46.2 & 64.3 & 62.5 & 39.1 \\
\hline Chloroethane & 0 & 0 & 0 & 0 & 2.3 & 0 & 4.2 & 0 \\
\hline Chloroform & 12.0 & 13.0 & 30.5 & 47.8 & 56.4 & 78.6 & 70.8 & 67.7 \\
\hline Chloromethane & 0 & 0 & 0 & 0 & 2.4 & 0 & 5.3 & 0 \\
\hline$o$-Chlorotoluene & 0 & 0 & 0 & 0 & 0 & 0 & 0 & 0 \\
\hline$p$-Chlorotoluene & 0 & 0 & 0 & 0 & 0 & 0 & 0 & 0 \\
\hline Dibromochloropropane & 0 & 0 & 0 & 0 & 0 & 0 & 0 & 0 \\
\hline Dibromomethane & 0 & 0 & 0 & 0 & 0 & 0 & 0 & 0 \\
\hline$o$-Dichlorobenzene & 0 & 4.3 & 1.6 & 0 & 0 & 0 & 0 & 1.0 \\
\hline$p$-Dichlorobenzene & 0 & 0 & 0 & 0 & 4.3 & 0 & 0 & 1.0 \\
\hline Dichlorodifluoromethane & 7.7 & 4.3 & 12.1 & 0 & 0 & 0 & 0 & 0 \\
\hline 1,1-Dichloroethane & 0 & 0 & 45.0 & 0 & 0 & 0 & 0 & 0 \\
\hline 1,2-Dichloroethane & 0 & 0 & 0 & 0 & 2.1 & 6.7 & 0 & 3.8 \\
\hline 1,1-Dichloroethene & 0 & 0 & 81.1 & 0 & 0 & 0 & 4.2 & 0 \\
\hline cis-1,2-Dichloroethene & 0 & 0 & 93.5 & 0 & 0 & 0 & 0 & 0 \\
\hline trans-1,2-Dichloroethene & 0 & 0 & 3.2 & 0 & 0 & 0 & 0 & 0 \\
\hline Dichloromethane & 0 & 0 & 0 & 9.7 & 6.4 & 0 & 0 & 1.0 \\
\hline 1,2-Dichloropropane & 0 & 0 & 0 & 0 & 0 & 0 & 4.2 & 0 \\
\hline 1,3-Dichloropropane & 0 & 0 & 0 & 0 & 0 & 0 & 0 & 0 \\
\hline 2,2-Dichloropropane & 0 & 0 & 0 & 0 & 0 & 0 & 0 & 0 \\
\hline cis-1,3-Dichloropropene & 0 & 0 & 0 & 0 & 0 & 0 & 0 & 0 \\
\hline Ethylbenzene & 7.7 & 8.7 & 0 & 23.3 & 43.5 & 28.6 & 42.3 & 46.7 \\
\hline Ethylene dibromide & 0 & 0 & 0 & 0 & 0 & 0 & 0 & 0 \\
\hline Fluorotrichloromethane & 0 & 0 & 20.7 & 0 & 0 & 0 & 0 & 0 \\
\hline Hexachlorobutadiene & 0 & 0 & 0 & 0 & 0 & 0 & 0 & 0 \\
\hline Isopropylbenzene & 0 & 0 & 0 & 0 & 0 & 0 & 0 & 0 \\
\hline
\end{tabular}


Appendix 4. Co-occurrence of volatile organic compounds in drinking water for randomly selected community water systems in the study area, 1993-98-Continued

[Co-occurrence is calculated as the percentage of samples with detections of compound specified by column that also had detections of compound specified by row, for example, 2.2 percent of the drinking-water samples with benzene detections also had bromochlormethane detections when both compounds were analyzed for in the same sample; values shown in bold when co-occurrence equals or exceeds 20 percent of 10 or more detertions of compound specified by column; NA, not applicable; ND, no detections of compound specified by column]

\begin{tabular}{|c|c|c|c|c|c|c|c|c|}
\hline \multirow[b]{2}{*}{ voc } & \multicolumn{8}{|c|}{ Co-occurrence, in percent } \\
\hline & $\begin{array}{c}1,2,4- \\
\text { Trimethyl- } \\
\text { benzene }\end{array}$ & $\begin{array}{c}1,3,5- \\
\text { Trimethyl- } \\
\text { benzene }\end{array}$ & $\begin{array}{l}\text { Vinyl } \\
\text { chloride }\end{array}$ & m-Xylene & o-Xylene & p-Xylene & $\begin{array}{l}m \text { - \& p- } \\
\text { Xylenes }\end{array}$ & $\begin{array}{l}\text { Xy'ones, } \\
\text { intal }\end{array}$ \\
\hline$p$-Isopropyltoluene & 15.4 & 21.7 & 0 & 0 & 0 & 0 & 0 & 0 \\
\hline Methyl ethyl ketone & 0 & ND & ND & 0 & 10 & 25.0 & 0 & 25.0 \\
\hline Methyl isobutyl ketone & 0 & ND & ND & ND & 25.0 & ND & 12.5 & ND \\
\hline Methyl tert-butyl ether & 25.0 & 0 & 10.3 & 20 & 8.3 & 33.3 & 0 & 10.6 \\
\hline Monochlorobenzene & 0 & 0 & 14.5 & 0 & 0 & 0 & 0 & 0 \\
\hline Naphthalene & 28.6 & 14.3 & 0 & 0 & 0 & 0 & 0 & 1.5 \\
\hline$n$-Propylbenzene & 7.7 & 8.7 & 0 & 0 & 0 & 0 & 0 & 0 \\
\hline Styrene & 0 & 0 & 0 & 0 & 0 & 0 & 0 & 1.9 \\
\hline 1,1,1,2-Tetrachloroethane & 0 & 0 & 0 & 0 & 0 & 0 & 0 & 0 \\
\hline 1,1,2,2-Tetrachloroethane & 0 & 0 & 0 & 0 & 0 & 0 & 0 & 0 \\
\hline Tetrachloroethylene & 3.8 & 4.3 & 51.6 & 0 & 2.1 & 0 & 4.2 & 2.8 \\
\hline Tetrahydrofuran & ND & ND & ND & ND & 0 & ND & 0 & ND \\
\hline Toluene & 7.7 & 4.3 & 0 & 37.9 & 29.5 & 35.7 & 12.0 & 26.7 \\
\hline 1,2,3-Trichlorobenzene & 0 & 0 & 0 & 0 & 0 & 0 & 0 & 0 \\
\hline 1,2,4-Trichlorobenzene & 0 & 4.3 & 0 & 0 & 0 & 0 & 0 & 0.9 \\
\hline 1,1,1-Trichloroethane & 3.8 & 0 & 48.4 & 0 & 0 & 0 & 0 & 1.9 \\
\hline 1,1,2-Trichloroethane & 0 & 0 & 0 & 0 & 0 & 0 & 0 & 0 \\
\hline Trichloroethylene & 0 & 0 & 51.6 & 3.2 & 0 & 0 & 0 & 2.8 \\
\hline 1,2,3-Trichloropropane & 0 & 0 & 0 & 0 & 0 & 0 & 0 & 0 \\
\hline Total Trihalomethanes & 0 & 0 & ND & 100 & 85.7 & 100 & 87.5 & 100 \\
\hline 1,2,4-Trimethylbenzene & NA & 82.6 & 0 & 3.4 & 0 & 0 & 0 & 3.2 \\
\hline 1,3.5-Trimethylbenzene & 73.1 & NA & 0 & 0 & 0 & 0 & 0 & 6.3 \\
\hline Vinyl chloride & 0 & 0 & NA & 0 & 0 & 0 & 0 & 0 \\
\hline$m$-Xylene & 5.0 & 0 & 0 & NA & 63.9 & 57.1 & ND & 40.9 \\
\hline$o$-Xylene & 0 & 0 & 0 & 69.7 & NA & 78.6 & 57.7 & 35.7 \\
\hline$p$-Xylene & 0 & 0 & 0 & 57.1 & 47.8 & NA & ND & 42.9 \\
\hline$m$ - \& $p$-Xylenes & 0 & 0 & 0 & NA & 100 & NA & $\mathrm{NA}$ & 0 \\
\hline Xylenes (total) & 33.3 & 57.1 & 0 & NA & NA & NA & NA & NA \\
\hline
\end{tabular}


